\title{
Eocene to Miocene tectonostratigraphic evolution of northwest New Zealand
}

By

Damian Orr

A thesis

submitted to the Victoria University of Wellington

in partial fulfilment of the requirements for the degree of Master of Science in Geology

School of Geography, Environment and Earth Sciences Victoria University of Wellington

2019 





\section{Abstract}

Reinga Basin is located northwest of New Zealand, along strike structurally from Northland and has a surface area of $\sim 150,000 \mathrm{~km}^{2}$. The basin contains deformed Cretaceous and Cenozoic strata, flat unconformities interpreted as sea level-modulated erosion surfaces and is intruded by volcanics. Persistent submarine conditions and moderate water depths has led to preservation of fossil-rich bathyal sedimentary records. This thesis presents the first seismic stratigraphic analysis tied to dredged rock samples and recent International Ocean Discovery Program (IODP) drilling. The Cenozoic tectonic evolution of Reinga Basin comprises four main phases. (1) Folding and uplift from lower bathyal occurred at 56-43 Ma along West Norfolk Ridge to produce wave ravinement surfaces. This phase of deformation in Reinga Basin pre-dates tectonic events onshore New Zealand. (2) Basin-wide 39-34 Ma compression and reverse faulting exposed early to middle Eocene strata at the seabed. This phase of deformation is also observed farther south in Taranaki. (3) Oligocene uplift is recorded by late Oligocene shallow-water fauna at Site U1508, and led to a 6 Myr hiatus (34-28 Ma) associated with flat wave ravinement surfaces nearby. The unconformity is temporally associated with: normal faulting near West Norfolk Ridge that created topography of Wanganella Ridge; onset of Reinga Basin volcanism; and emplacement of South Maria Allochthon. Thin-skinned deformation and volcanism post-date thick-skinned reverse faulting and folding. The end of reverse faulting near South Maria Ridge is determined from undeformed Oligocene strata that have subsided 1500-2000 m since 36-30 Ma. (4) During the final phase of Reinga Basin deformation, South Maria Ridge subsided 900-1900 m from middle shelf to bathyal depths from 23-19 Ma. Deformation migrated southeastwards, culminating in Northland Allochthon emplacement (23-20 Ma) and onshore arc-volcanism at 23-12 Ma. Eocene onset of tectonic activity in northern New Zealand is shown to be older than previously recognised and it was broadly synchronous with other events related to subduction initiation and plate motion change elsewhere in the western Pacific. 


\section{Acknowledgements}

Nothing I have ever done, or will ever do, will be accomplished alone. For that reason, I have many people to thank.

Firstly, I would like to thank my supervisor, Rupert Sutherland. You are an exceptional geoscientist and the standards you set for your students is second to none. I am truly grateful for the amount of guidance, time and wisdom you invested in me during this challenging year. Your door was always open and you were always willing to discuss whatever was on my mind. I am also thankful for the opportunity you gave me to visit the IODP core repository in Texas. I extend my thanks to Wanda Stratford, the numerous questions you answered throughout the year, and the feedback you provided down the stretch greatly benefited the quality of this thesis.

I am very grateful for the finical support I received through the OMV New Zealand scholarship award. In particular, thanks to Joseph Coyle for helping with the application process, and the exploration team for showing an interest in this project.

To Peter and Virginie Blum, thank you for hosting me during my time in Texas.

To Clarrie, Dani and Jiten; you guys are awesome. Thank you for all the work, and mostly non-work related discussions that made this past year enjoyable.

To Callum, thank you for all the long back and forth discussions we had, they definitely improved the outcome of this work.

To my flat-mates, thank you for offering a relaxing environment to come home to after long days thinking about rocks.

To Rebecca, thank you for being the most kind, caring and supportive person I have ever known.

Finally, to my family; your encouragement and support throughout my education means more than you will ever know. Thanks for always believing in me. 


\section{Contents}

$\begin{array}{ll}\text { Abstract } & \text { i }\end{array}$

Acknowledgements $\quad$ iii

Contents $\quad$ vii

List of Figures $\quad x$

List of Tables $\quad$ xi

1 Introduction $\quad 1$

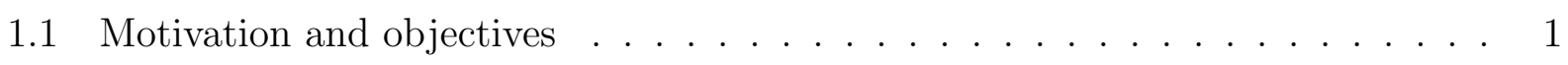

1.2 Study Area . . . . . . . . . . . . . . . . . . . . 5

1.2.1 Western Ridges ...................... 5

1.2 .2 Eastern Ridges . . . . . . . . . . . . . . . . . . . 6

1.3 Previous work in Reinga Basin . . . . . . . . . . . . . . . . . . . 7

1.4 Geological Setting . . . . . . . . . . . . . . . . . . 8

1.4.1 Mesozoic Subduction . . . . . . . . . . . . . . 8

1.4.2 Cretaceous Extensional Faulting . . . . . . . . . . . . . 10

1.4.3 Allochthonous Rocks . . . . . . . . . . . . . . . . . 11

1.4.4 Late Cretaceous-Paleocene passive margin . . . . . . . . . . . . . . 12

1.4.5 Eocene-Oligocene Compressional Tectonics . . . . . . . . . . . . . 13

1.4.6 Neogene Arc . . . . . . . . . . . . . . . . . 15

$\begin{array}{lll}2 & \text { Seismic Interpretation } & 17\end{array}$

2.1 Seismic Data . . . . . . . . . . . . . . . . . . 17

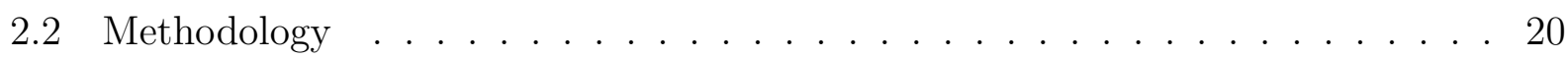


2.2.1 Application to Reinga and Northland basins . . . . . . . . . . . . . 23

2.3 Results of seismic interpretation . . . . . . . . . . . . . . . . . . 24

2.3.1 Horizon Maps . . . . . . . . . . . . . . . . . . . . . . 24

2.3.2 Horizon UB3 and Seismic Unit $4 \ldots \ldots$. . . . . . . . . . 27

2.3.3 Horizon UB4 and Seismic Unit $5 \ldots \ldots$. . . . . . . . . . . 30

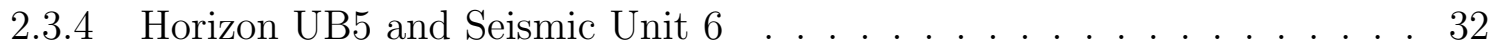

2.3.5 Horizon UB6a and Seismic Unit 6a . . . . . . . . . . . . 35

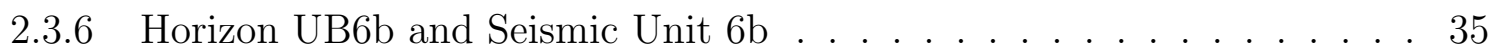

2.3.7 Horizon UB6 and Seismic Unit $7 \ldots \ldots$. . . . . . . . . . 36

2.3.8 Horizon UB7 and Seismic Unit $8 \ldots \ldots$. . . . . . . . . 36

2.3.9 Horizon UB8 and Seismic Unit $9 \ldots \ldots$. . . . . . . . . . 38

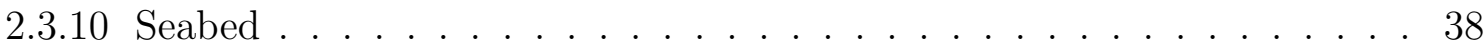

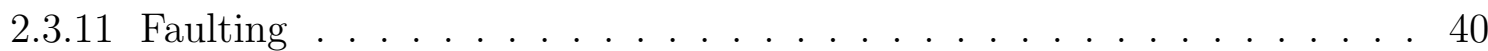

2.3.12 Allochthons . . . . . . . . . . . . . . . . . 42

2.3 .13 Volcanic edifices . . . . . . . . . . . . . . . . . . . . 44

2.3.14 Wave ravinement surfaces . . . . . . . . . . . . . . . . . 46

2.4 Synthesis of seismic stratigraphy . . . . . . . . . . . . . . . . 48

2.5 Depth Conversion . . . . . . . . . . . . . . . . . . . . . 51

3 Rock Samples $\quad 55$

3.1 Age and paleoenvironment . . . . . . . . . . . . . . . . 55

3.2 Dredge Samples . . . . . . . . . . . . . . . . . . . . . 57

3.2.1 TAN1312 Site D43 . . . . . . . . . . . . . . . 60

3.2 .2 TAN1312 Site D48 . . . . . . . . . . . . . . . . 62

3.2.3 RE9032 Site RE7 . . . . . . . . . . . . . . . . . . . . 62

3.2 .4 TAN1312 Site D27 . . . . . . . . . . . . . . . . . 64

3.2 .5 TAN1312 Site D21 . . . . . . . . . . . . . . . 64

3.2 .6 TAN1312 Site D13 . . . . . . . . . . . . . . 66

3.2 .7 TAN1312 Site D5 . . . . . . . . . . . . . . 66

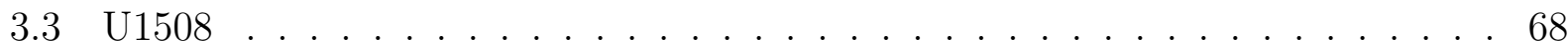

3.3.1 Time-to-depth . . . . . . . . . . . . . . . . 68

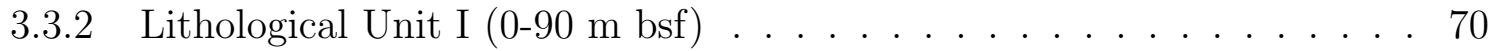

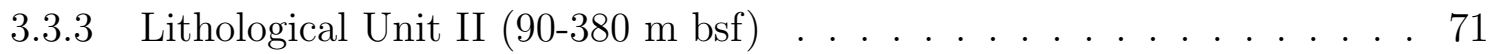




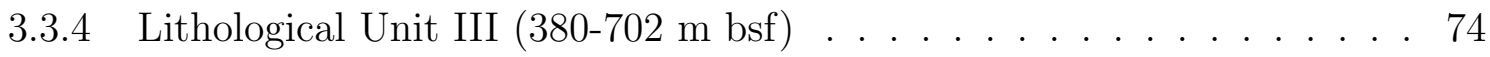

3.4 Waka Nui-1 . . . . . . . . . . . . . . . . . . . 76

3.4.1 Time-to-depth . . . . . . . . . . . . . 76

3.4.2 Lithological Unit $8(671-731 \mathrm{~m} \mathrm{bsf}) \ldots \ldots \ldots . \ldots . \ldots 78$

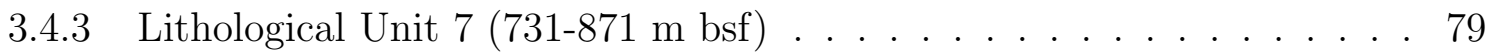

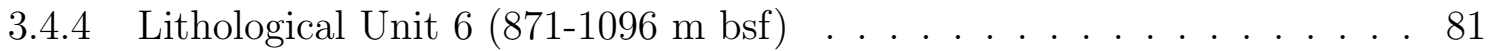

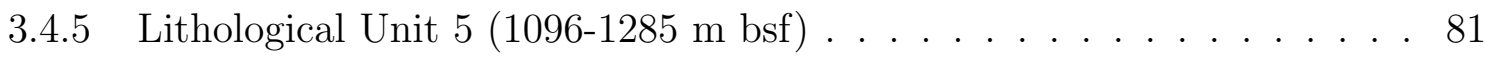

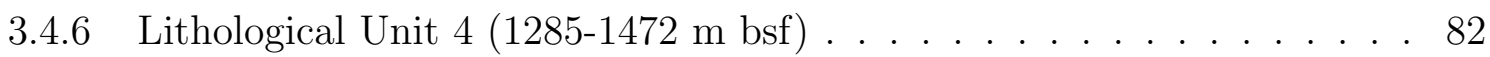

3.5 Synthesis of offshore rock samples . . . . . . . . . . . . . . . . 84

4 Basin History $\quad 89$

4.1 Late Cretaceous-Paleocene . . . . . . . . . . . . . . . . . . . . . . 89

4.2 Early to middle Eocene . . . . . . . . . . . . . . . . . . . . . . . 90

4.3 Late Eocene . . . . . . . . . . . . . . . . . . . . . . . . 93

4.4 Oligocene . . . . . . . . . . . . . . . . . . . 96

4.5 Early to middle Miocene . . . . . . . . . . . . . . . . . . . . . 99

5 Discussion and conclusions 103

5.1 Timing and style of deformation . . . . . . . . . . . . . . . . 103

5.2 Paleogeography and vertical tectonic motions f . . . . . . . . . 106

5.3 Volcanic history . . . . . . . . . . . . . . . . . . . 109

5.4 Conclusions . . . . . . . . . . . . . . . . . . . . 110

$\begin{array}{ll}\text { References } & 113\end{array}$

$\begin{array}{lll}\text { Appendix A New Zealand geological timescale } & 131\end{array}$

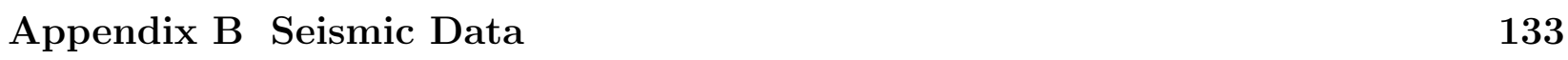

B.1 Seismic survey details . . . . . . . . . . . . . . . . . . . . . . 133

B.2 Time-to-depth points . . . . . . . . . . . . . . . 134

B.3 Location of seismic figures . . . . . . . . . . . . . . . . . . 141 


\section{List of Figures}

1.1 Physiography map of northwestern New Zealand . . . . . . . . . . . . . . 3

1.2 Onshore geology of Northland New Zealand . . . . . . . . . . . . . . . . . 9

2.1 Overview map of the seismic data used in this study . . . . . . . . . . . 18

2.2 Polarity convention used in this study . . . . . . . . . . . . . . . . 19

2.3 Characteristics of seismic reflection terminations and configurations . . . . . 21

2.4 Seismic-stratigrapic framework from previous studies . . . . . . . . . . . 23

2.5 Two-way-time grids of horizons UB3-UB8 . . . . . . . . . . . . . . . 25

2.6 Two-way-time isopach grids of units U4-U9 . . . . . . . . . . . . . . . 26

2.7 Stratal geometries in western Reinga Basin . . . . . . . . . . . . . . 28

2.8 Stratal geometries near IODP Site U1508 . . . . . . . . . . . . . . . 29

2.9 Folding in northwestern Reinga Basin . . . . . . . . . . . . . . . 31

2.10 Stratigraphic relationships along strike from Site U1508 . . . . . . . . . . . 33

2.11 Intra-U6 strata in southeast Reinga Basin . . . . . . . . . . . . . . . 34

2.12 Two-way-time structure grids of horizons UB6a and UB6b . . . . . . . . . 35

2.13 Down-dip stratigraphic relationships in Northland Basin . . . . . . . . . . 37

2.14 Seabed features near Reinga Ridge . . . . . . . . . . . . . . . . 39

2.15 Structural map of Reinga and Northland basins showing mapped faults . . . . 41

2.16 Mapped allochthons near South Maria Ridge and Northland Peninsula . . . . 43

2.17 Volcanic edifices in Reinga and Northland basins . . . . . . . . . . . . . . . 45

2.18 Wave ravinement surfaces across Reinga Basin bounding ridges . . . . . . . . . 47

2.19 Summary of seismic-stratigraphic units of inferred Eocene to Recent age . . . 50

2.20 Time to depth relationship for Reinga and Northland basins . . . . . . . . . . 52

2.21 Depth structure grids of seismic horizons UB3-UB8 $\ldots \ldots \ldots$ 
2.22 Depth isopach grids of seismic units U4-U9 . . . . . . . . . . . . . . . 54

3.1 Marine paleoenvironment classification scheme . . . . . . . . . . . . . 56

3.2 Locations of dredge samples and boreholes used in this study . . . . . . . . . . 58

3.3 TAN1312 dredge sites D43 and D48 . . . . . . . . . . . . . . . 61

3.4 RE9032 dredge site RE7 and TAN1312 dredge site D27 . . . . . . . . . . . . 63

3.5 TAN1312 dredge site D21 . . . . . . . . . . . . . . . . . 65

3.6 TAN1312 dredge sites D13 and D5 . . . . . . . . . . . . 67

3.7 Two-way-time with depth relationship for IODP Site U1508 . . . . . . . . . 69

3.8 Age with depth relationship for IODP Site U1508 . . . . . . . . . . . . 73

3.9 Seismic reflection lines showing Site U1508 ties to seismic . . . . . . . . . 75

3.10 Two-way-time with depth relationship for the Waka Nui-1 well . . . . . . . . . 77

3.11 Age with depth relationship for Waka Nui-1 well . . . . . . . . . . . . . 80

3.12 Seismic lines showing Waka Nui-1 well ties to seismic . . . . . . . . . . . 83

3.13 Stratigraphic correlation between dredge and borehole samples . . . . . . . . 87

4.1 Eocene to Miocene paleogeography maps of northwest New Zealand . . . . . . 91

4.2 Two phases of compression near West Norfolk Ridge . . . . . . . . . . . . 93

4.3 Basin-wide late Eocene compression . . . . . . . . . . . . . . . . . . 95

4.4 Oligocene deformation events . . . . . . . . . . . . . . . 97

4.5 Onset of volcanism in Reinga and Northland basins tied to boreholes . . . . . 100

5.1 Map of Eocene deformation in northern Zealandia . . . . . . . . . . . . . . . 104

5.2 Timing of uplift and subsidence of basin-bounding ridges . . . . . . . . . . 107

5.3 Seismic sections of wave-ravined basin-bounding ridges . . . . . . . . . . 108

5.4 Map of volcanism in northwest New Zealand . . . . . . . . . . . . . . . 110

A.1 New Zealand Cretaceous-Cenozoic timescale . . . . . . . . . . . . . . . . 132

B.1 Location of seismic sections in Chapter $4 \ldots \ldots$. . . . . . . . . . . . 141 


\section{List of Tables}

3.1 Classification of carbonate sedimentary rocks . . . . . . . . . . . . 57

3.2 Summary of dredge sample data used in this study . . . . . . . . . . . . . . 59

3.3 Reflector two-way-time with depth relationship at Site U1508 . . . . . . . . 70

3.4 Reflector two-way-time with depth relationship at Waka Nui-1 . . . . . . . . 78

3.5 Age, thickness and lithology summary of offshore rock samples in this study . 86

B.1 Acquisition parameters of seismic data . . . . . . . . . . . . . 133

B.2 Calculated two-way-time with depth values . . . . . . . . . . . 134 


\section{Chapter 1}

\section{Introduction}

\subsection{Motivation and objectives}

The Norfolk Ridge system is a northern part of the vast submerged continent of Zealandia (Mortimer et al., 2017), and lies between Australia, New Caledonia and New Zealand (Figure 1.1). It includes Reinga Basin and northwest New Zealand (Bache et al., 2012b). Reinga Basin is a topographic depression with typical water depths of $1500-2500 \mathrm{~m}$. It is bounded to the northeast by Reinga Ridge, South Maria Ridge and Northland Peninsula of New Zealand's North Island (Te Ika-a-Māui), and is bounded to the southwest by West Norfolk Ridge and Wanganella Ridge (Figure 1.1). The southeastern margin is treated as contiguous with Northland Basin (Stagpoole et al., 2009). Topographic highs at the edges of Reinga Basin are composed of deformed sediment and basement rock with typical water depths in the range of 500-1000 m, but locally shallower (Sutherland et al., 2019a).

The surface area of Reinga Basin $\left(\sim 156 \mathrm{~km}^{2}\right)$ is similar to New Zealand's North Island. Basin fill encompasses Early Cretaceous syn-tectonic deposits buried by up to $6000 \mathrm{~m}$ of Late Cretaceous-Recent strata (Herzer et al., 1997), including folded Eocene strata (Bache et al., 2012b). Deformed basin strata are a manifestation of plate boundary deformation. The northeastern margin of Reinga Basin is inferred to be near the southern end of where Tonga-Kermadec subduction initiation occurred (Bache et al., 2012a,b; Browne et al., 2016; Sutherland et al., 2017), but the basin is now 300-700 km from the active plate boundary (Figure 1.1).

Reinga Basin was discovered on the basis of reconnaissance seismic reflection surveys (Herzer et al., 1997), but had not been drilled. Onshore geology of Northland has been mapped, and there is an extensive grid of seismic data in the adjacent Northland Basin. The nearest offshore petroleum exploration well of significance to Reinga Basin is Waka 
Nui-1 275 km southeast (Milne and Quick, 1999). It intersects a near complete Cenozoic sequence unconformably overlying Mesozoic basement rock. Northland and Northland Basin provide context for Reinga Basin because they are along strike structurally, presumably have a similar tectonic history, and may provide insight to sediment sources.

Acquisition of the high-quality REI09 seismic survey occurred in 2009 as part of an initiative to maximise potential economic benefits arising from discovery of commercial oil and gas (Ministry of Economic Development, 2009a). Subsequent seismic-stratigraphic interpretation enhanced regional understanding of Reinga Basin (Bache et al., 2012a,b; Sutherland et al., 2017), and provided rationale for targeted seabed dredging during the TAN1312 voyage (Bache et al., 2014c). Age, lithology and paleoenvironmental analyses were carried out on samples and broadly related to onshore and nearshore geology of New Zealand (Browne et al., 2014, 2016). Samples dredged from >1500 m water depth in Reinga Basin show Eocene strata are exposed at the seabed and some contain shallow-marine fossils, requiring large $(>1$ $\mathrm{km}$ ) vertical motions associated with inferred subduction initiation (Sutherland et al., 2017).

International Ocean Discovery Program (IODP) Expedition 371 drilled and sampled sediments on the flank of South Maria Ridge at Site U1508 (Figure 1.1). The site was selected on the basis of interpreted seismic reflection data (Bache et al., 2012a,b) and the Eocene ages of folded strata at the seabed (Browne et al., 2014, 2016). Stratigraphy near the site was previously mapped and interpreted, but was unsampled. Persistent submarine conditions and moderate water depths led to preservation of fossil-rich bathyal sediments that date and confirm the existence of Eocene tectonic signals of change, including compression, uplift, subsidence, and volcanism (Sutherland et al., 2018, 2019a). Recovery of reworked shallow-water $(<400 \mathrm{~m})$ fossils near a flat sea level-modulated unconformity provide direct evidence for past vertical motions. Detailed age-models were constructed and tied to seismic reflection data (Sutherland et al., 2018).

Reinga Basin is deformed, intruded by volcanics, and contains flat sea level-modulated unconformities. However, the evolution of Reinga Basin is poorly constrained. Age, lithology and paleoenvironment inferences have been made from the onshore geology of Northland, and seismic stratigraphic ties to Waka Nui-1 and deep-water wells in Taranaki Basin (Stagpoole et al., 2009; Bache et al., 2012a,b). Dredge samples and IODP Site U1508 cores provide new information, but have not been related to seismic-stratigraphy in detail. Hence, there is a need to integrate these new rock samples to seismic stratigraphy and precisely date Cenozoic deformation events in Reinga Basin which have been attributed to subduction initiation. 


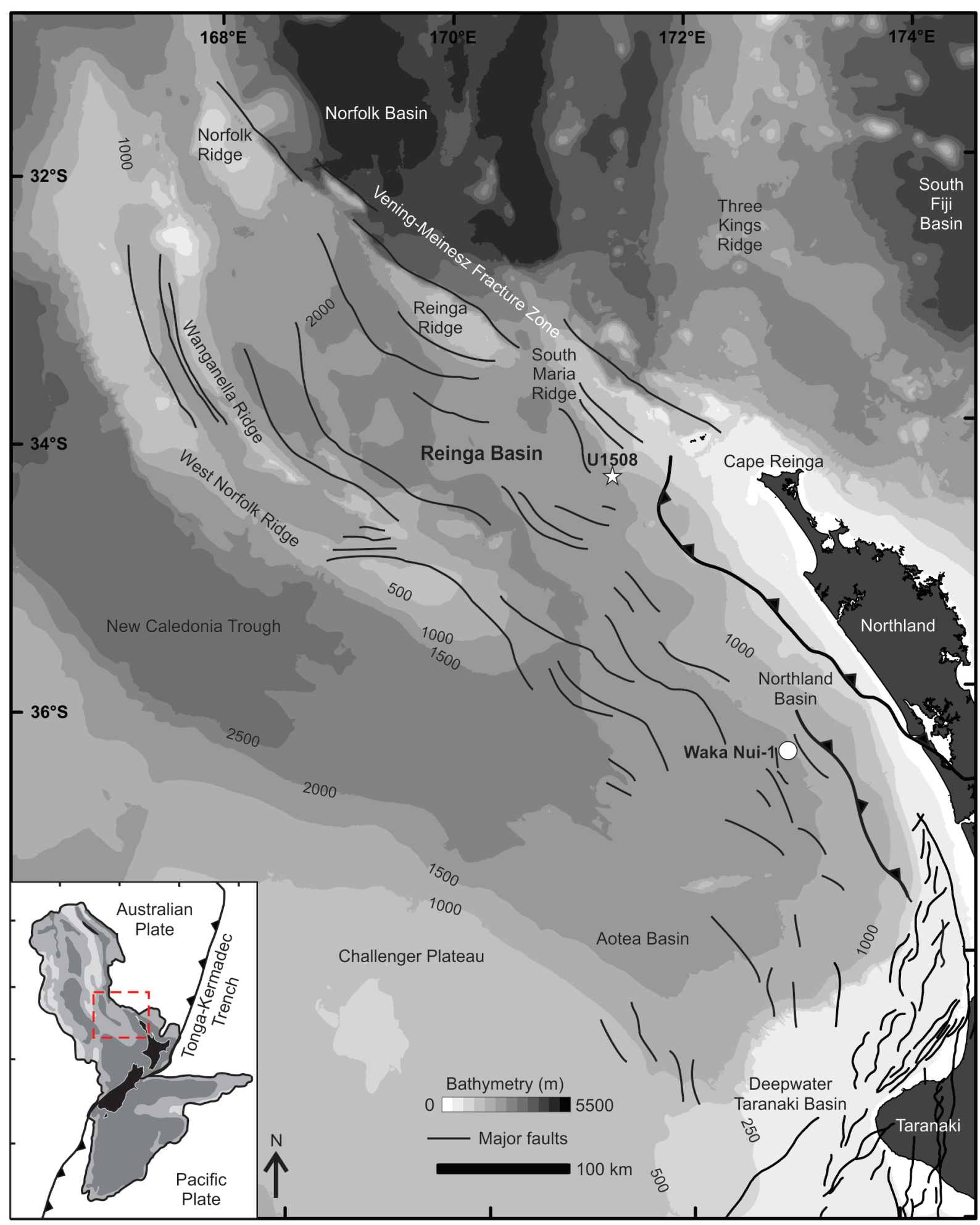

Figure 1.1: Structural and physiographic overview of offshore northwestern New Zealand, showing bathymetry (Mitchell et al., 2012), undifferentiated major faults (Bache et al., 2012a,b) and detachment faults (Isaac et al., 1994; Bache et al., 2014a). IODP Site U1508 (star) is located 275 $\mathrm{km}$ northwest of Waka Nui-1. Inset shows the Zealandia continent (Mortimer et al., 2017) and the present tectonic setting within New Zealand. Reinga and Northland basins (dashed red box) are presently situated 300-700 km from the Tonga-Kermadec trench where the Pacific Plate is obliquely subducting beneath the Australian Plate. 
The overarching objectives of this thesis are listed below.

i Re-interpret seismic reflection data using the principles of seismic stratigraphy to identify key units and unconformities formed during Cenozoic tectonic events in Reinga and Northland basins (Chapter 2).

ii Analyse data from TAN1312 dredge samples (Bache et al., 2014c; Browne et al., 2014, 2016), IODP Site U1508 (Sutherland et al., 2018, 2019a,b) and Waka Nui-1 (Milne and Quick, 1999; Strong et al., 1999; Stagpoole, 2011) boreholes, to infer age, lithology and paleoenvironment for seismic-stratigraphic units (Chapter 3).

iii Determine regional timing of tectonic events in Reinga Basin through the first integrated stratigraphy of offshore northwest New Zealand. This will lead to paleogeographical reconstructions and a revised basin history (Chapter 4) and will address key questions:

(a) What was the timing and style of deformation?

(b) What was the timing and magnitude of uplift and subsidence?

(c) What was the timing of volcanism?

iv Discuss implications for the tectonic development of Reinga Basin with a particular focus on time-space relationships (Chapter 5). 


\section{$1.2 \quad$ Study Area}

The seabed consists of bathymetric highs and lows: West Norfolk Ridge, Wanganella Ridge, Reinga Ridge, South Maria Ridge and the interspersed Reinga Basin (Figure 1.1). Regional bathymetry shows a generally flat basin floor with 1500-2500 m water depths. Bathymetric contours trend northwest to southeast, and run broadly orthogonal to the active plate boundary of New Zealand. Basin margins rise $\sim 1500 \mathrm{~m}$ high above the basin floor, with depths as shallow as $\sim 250 \mathrm{~m}$ (Stagpoole et al., 2014). Wanganella Trough is a 1500-1700 m deep sub-basin between West Norfolk Ridge and Wanganella Ridge that forms a separate northwestern extension to Reinga Basin.

\subsubsection{Western Ridges}

The crest of West Norfolk Ridge has distinct segments: a northern section where water depths range from 600-900 m, and a southern section of deeper 1400-1600 m water depths (Stagpoole et al., 2014). Multi-beam echo-sounder bathymetry taken on the TAN1312 voyage identifies a series of gullies and small canyons with high back-scatter intensity that suggests active delivery of sediments to the basin floor (Bache et al., 2014c), possibly most active during sea level low-stands (Nelson et al., 1982; Nelson and Hancock, 1984). Dredge samples indicate the ridges are comprised of Brook Street Terrane and Median Batholith basement rock (Mortimer et al., 1998; Mortimer, 2004). In addition, West Norfolk Ridge is characterised by a prominent high-amplitude magnetic anomaly, leading to a general agreement that it is underlain by continental crust (Eade, 1988; Sutherland, 1999). Seismic reflection data show a thin Cenozoic sedimentary cover, variably composed of Oligocene limestone and calcareous mudstone (Browne et al., 2014, 2016).

Wanganella Ridge is substantially narrower than West Norfolk Ridge, ranging from $<5$ $\mathrm{km}$ to $\sim 20 \mathrm{~km}$ width along its length (Figure 1.1). The seafloor along ridge crests range from c. $100 \mathrm{~m}$ at the northern extent to $800 \mathrm{~m}$ farther south. Interspersed saddles descend to water depths of 1400-1600 m (Stagpoole et al., 2014). Part of Wanganella Ridge is characterised by the same high-amplitude magnetic anomaly as West Norfolk Ridge, indicating a similar basement composition (Herzer et al., 1997; Mortimer et al., 1998). Dredge samples indicate the ridge has a thin veneer of late Oligocene to early Miocene bathyal, foraminiferal limestone (Herzer et al., 1997). 


\subsubsection{Eastern Ridges}

Reinga Ridge comprises two identifiable segments, a 5-10 km wide northern ridge that descends into $\sim 3000 \mathrm{~m}$ water depths to the northeast, and a 20-30 km southern ridge in 500-600 $\mathrm{m}$ water depth (Stagpoole et al., 2014). It is separated from the adjacent South Maria Ridge by a 1600-1700 m deep saddle, and is associated with a $50 \mathrm{~km}$ left-stepping linear fault scarp at its northern boundary with Norfolk Basin (Herzer and Mascle, 1996). A general high back-scatter intensity on the ridge crest suggests hard substrates are exposed at the seabed (Bache et al., 2014c). Analysed dredge samples indicate that ridges expose Tangihua Complex rocks (Brook et al., 1988; Mortimer et al., 1998) and bathyal limestone and mudstones of Paleocene-Eocene age (Browne et al., 2014). TAN1312 swath bathymetry delineates $>100$ $\mathrm{m}$ wavelength and $>5 \mathrm{~km}$ axial length sediment waves generated by the Tasman Front, which is the southwestern extension of the East Australian Current (Bache et al., 2014c; Chiswell et al., 2015).

The boundary between Reinga and Norfolk basins is the Vening-Meinesz Fracture Zone (VMFZ). It is identified by northwest-trending, sharp changes in bathymetric contours (Figure 1.1). Low-amplitude gravity anomalies delineate steep fault scarps along the northeastern margin (Herzer et al., 2009), suggested to be related to an episode of strike-slip deformation based on seismic stratigraphy (Herzer and Mascle, 1996). Dextral displacement and differential uplift is interpreted to accommodate isolation of Reinga Basin and bounding ridges from Oligocene to Miocene back-arc extension in Norfolk Basin (Mortimer et al., 2007), which is bracketed between 25-15 Ma, based on geomchemical analysis from seamounts in South Fiji Basin (Mortimer et al., 2007; Herzer et al., 2009).

South Maria Ridge is the northwestern extension of Northland Plateau. Width of the ridge ranges from $70 \mathrm{~km}$ near Cape Reinga, to $30 \mathrm{~km}$ near Reinga Ridge. Analysis of backscatter data by Stagpoole et al. (2014) shows high reflectivity associated with eroded rock on ridge crests. Uniform low- to very-low reflectivity on the relatively flat-lying seabed implies a soft substrate. Analysis of bottom samples suggest that South Maria Ridge is accumulating carbonate gravels and sand with $50 \%$ bryozoan fragments; overlying a bedrock geology of mainly Cretaceous submarine volcanics and Muruhiku Terrane (Nelson et al., 1982; Nelson and Hancock, 1984). Basin-ward slopes on South Maria Ridge can be inferred from regional bathymetry to delineate sediment flow pathways into Reinga Basin, which are likely most active during sea level low-stands (Nelson et al., 1982; Nelson and Hancock, 1984). 


\subsection{Previous work in Reinga Basin}

The stratigraphy and structure of Reinga Basin were analysed by Herzer et al. (1997). Using seismic-reflection, dredge sample, gravity and magnetic data, an initial basin history was inferred: (1) Terrestrial pre-rift and syn-rift Cretaceous sequences; (2) Cretaceous rift-filling marine sequences; (3) Paleocene to Eocene blanket sequence; (4) a condensed Oligocene sequence, manifest by a high-amplitude seismic reflector that is tied to Taranaki Basin; and (5) Miocene uplift of flanking ridges, leading to increased sediment thickness.

Following acquisition of high-quality REI09 2D seismic reflection data, Bache et al. (2012a,b) revised the stratigraphy and structure of Reinga Basin by tying to Waka Nui1, which was not drilled when Herzer et al. (1997) made their analysis. A revised basin history was postulated: (1) Late Cretaceous extension and deposition into graben structures; (2) Late Cretaceous to Eocene passive subsidence and burial of extensional structures; (3) Eocene contraction and reverse faulting; (4) Oligocene to early Miocene subsidence and condensed sedimentation; and (5) middle Miocene contraction leading to uplift of Wanganella Ridge.

Interpretation of seismic data formed a basis for collecting dredge samples, to provide constraints on the geology and tectonic history (Bache et al., 2014c). Sandstone, mudstone and limestone samples were analysed and broadly correlated to formations with similar characteristics across New Zealand (Browne et al., 2014). Dredge samples were correlated to high-order stratigraphy (Bache et al., 2014a; Mortimer et al., 2014b) and reveal that folded strata have Paleocene to Eocene ages and were deposited in passive, bathyal environments (Browne et al., 2016; Sutherland et al., 2017).

IODP Expedition 371 Site U1508 was drilled in Reinga Basin with a primary objective to understand Tonga-Kermadec subduction initiation through recovery of Paleogene sediment records (Sutherland et al., 2018). The site is located appropriately near an erosion surface, reverse faults and folds, and volcanoes. Discovery of shallow-water fossils provides evidence of substantial Cenozoic vertical motions. High-quality age models were constructed and can be tied to seismic-reflection data and hence provide strong constraints of the timing of uplift, subsidence, faulting and folding and volcanism. Recovery of a detailed biostratigraphic record and paleoenvironmental interpretations allow for construction of new paleogeographic maps for the basin, with implications for sedimentation and tectonics, and is the crux of this study. 


\subsection{Geological Setting}

The tectonic history of northern New Zealand can be simplified into five phases with approximate ages: Mesozoic Gondwana subduction (350-100 Ma); Cretaceous continental rifting (100-80 Ma); Cretaceous-Eocene passive margin (80-50 Ma); Eocene-Oligocene compressive tectonics (50-24 Ma); Neogene arc (24-0 Ma).

\subsubsection{Mesozoic Subduction}

During Late Paleozoic to Mesozoic times, the Norfolk Ridge system was part of the Pacificfacing Gondwana continental margin (Laird and Bradshaw, 2004) where sedimentary basins in a trench-slope setting accumulated the Torlesse Supergroup (MacKinnon, 1983). Subduction along the margin persisted until 110 Ma when the Hikurangi Plateau first entered the system and ultimately ceased at 100 Ma (Davy et al., 2008; Davy, 2014).

Permian-Early Cretaceous rocks in Northland comprise four metasedimentary terranes, and one volcaniclastic terrane that were amalgamated in Mesozoic time (Isaac et al., 1994, 1996; Edbrooke, 2001; Edbrooke and Brook, 2009; Stagpoole et al., 2009). Murihiku terrane is predominantly composed of volcanigenic sandstone, mudstone (Ballance and Campbell, 1993) and coal measures (Milne and Quick, 1999). Dun Mountain-Maitai Terrane is marked by a narrow zone of serpentinised ultramafic rocks, delineated by the Junction Magnetic Anomaly (Hunt, 1978; Hatherton and Sibson, 1970; Sutherland, 1999). Caples terrane comprises tuffaceous sandstone and mudstone with intercalated basalt, siliceous mudstone and chert in northern Northland (Mortimer, 2004). Bay of Islands Terrane contains Permian, Triassic and Early Jurassic basalt, chert and limestone assemblages that are tectonically intercalated, or reworked, into Permian to Jurassic trench and trench-slope sandstones and mudstones (Spörli, 1978; Black, 1994; Mortimer, 2004). Volcaniclastic Mount Camel Terrane comprises intercalated basalt and basaltic andesite lava, pillow lava, rhyolitic tuff, tuff-breccia, conglomerate, and indurated sandstone, and mudstone subject to variable mesoscopic slump folding (Isaac et al., 1988, 1996).

Continental "basement" beneath bathymetric highs is inferred to be similar to rocks found in New Zealand, based on dredge samples and magnetic anomalies (Mortimer et al., 1998; Mortimer, 2004; Sutherland, 1999). High-amplitude magnetic anomalies (Sutherland, 1999) and a single dredge sample (Mortimer et al., 1998) from West Norfolk Ridge suggests that ridges are composed of Brook Street Terrane and Median Batholith basement rocks (Mortimer, 2004). 


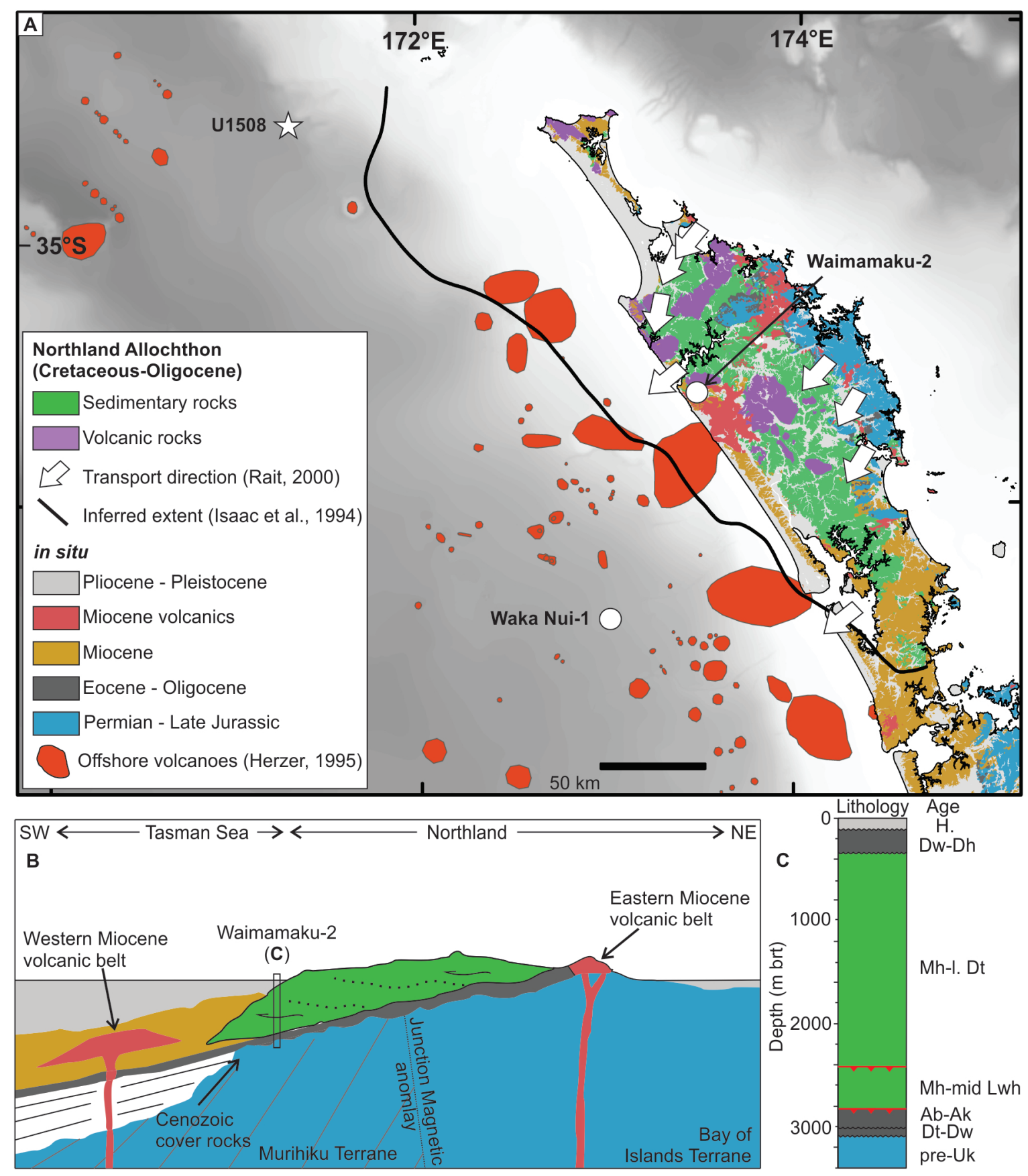

Figure 1.2: (A) Onshore geology of Northland, New Zealand (simplified from Isaac et al. 1996 and Edbrooke and Brook 2009). Cretaceous to Oligocene sedimentary constituents of the Northland Allochthon comprise Mangakahia, Motatau and Tupou complexes, and the volcanic component comprises the Tangiha Complex. White arrows indicate Oligocene to Miocene Northland Allochthon transport directions at different locations (after Rait 2000). Solid line represents the inferred northwestern extent of Northland Allochthon (after Isaac et al. 1994). Extensive sub-marine volcanoes are observed to the west of Northland (after Herzer 1995). (B) Schematic structural section through Northland Peninsula, based on outcrop units, showing erosion to the east and burial with onlap to the west (after Hayward 1993; Jiao et al. 2017). (C) Simplified stratigraphic column for Waimamaku-2 (NZ Petroleum Exploration Co Ltd, 1972). Ages follow the New Zealand geological timescale (after Raine et al. 2015 - see Appendix A) for timescale. 


\subsubsection{Cretaceous Extensional Faulting}

The tectonic regime along the Tasman sector of the Gondwana margin changed during the Cretaceous from subduction and convergence to widespread rifting and extension. Subduction related calc-alkaline and adakitic igenous activity characterises the early rift phase (130-110 Ma), whereas intraplate rift volcanism characterises later activity after 105-97 Ma in New Zealand (Mortimer et al., 1999; Tulloch et al., 2009). Widespread intracontinental rifting and extension from 100-85 Ma was instrumental in the development of many sedimentary basins in New Zealand (King, 2000a), and is manifest by a major, New Zealand-wide angular unconformity during Early Cretaceous (c. $105 \mathrm{Ma}$ ) time (Laird and Bradshaw, 2004; Bache et al., 2014a). Culmination of the rifting event is indicated by magnetic anomalies along the western edge of Lord Howe Rise, contemporaneous with opening of the Tasman Sea at 80-52 Ma (Gaina et al., 1998; Sutherland, 1999).

Faulting created north-to-northeast trending sub-basins in Taranaki Basin (King and Thrasher, 1996; Strogen et al., 2017), and northwest trending sub-basins in Northland Basin (Isaac et al., 1994), and Reinga Basin (Herzer et al., 1997; Bache et al., 2012a,b). Reinga Basin is likely underlain by continental crust affected by Late Cretaceous rifting (Herzer et al., 1997; Lafoy et al., 2005; Bache et al., 2012a,b). Late Cretaceous rift-basins contain terrestrial coastal plain deposits overlain by transgressive marine sandstones and mudstones in Canterbury, western South Island, Taranaki and Great South basins (Field et al., 1989; Turnbull and Uruski, 1993; King and Thrasher, 1996; Cook et al., 1999), and have been inferred in Reinga Basin based on dredge (Browne et al., 2016) and seismic data (Uruski, 2004; Bache et al., 2012a,b). Lateral ubiquity of terrestrial and shallow marine facies is confirmed to a certain extent by Turonian-Coniacian (94-86 Ma) age carbonaceous sandstone and mudstone dredged from West Norfolk Ridge (Herzer et al., 1997, 1999).

Middle to Late Cretaceous autochthonous rocks outcrop on eastern Northland Peninsula (Figure 1.2A). Transgressional breccia-conglomerate and mudstone of Whatuwhiwhi Formation unconformably overlie basement and is in turn unconformably overlain by thin-bedded cherts of Waiari Formation (Isaac et al., 1988; Hayward et al., 1989). The latter is equivalent to parts of the Whangai Formation of East Coast Basin (Moore, 1988; Isaac et al., 1994). Initial deposition of these formations in the early Haumurian (c. $84 \mathrm{Ma}$ ) marks the onset of a dominant fining-up sedimentation phase across Zealandia (King, 2000a; Mortimer et al., $2014 b)$. 


\subsubsection{Allochthonous Rocks}

Most Cretaceous to Oligocene sedimentary and volcanic rocks onshore Northland occur within a series of fault-bound units that compose the Northland Allochthon (Figure 1.2) (Ballance and Spörli, 1979). Four major thrust-bound units are widespread throughout Northland: volcanic Tangihua Complex, and sedimentary Tupou, Mangakahia and Motatau complexes (Isaac et al., 1994).

Tangihua Complex comprises a series of fault bound masiffs containing ophiolite and intercalated sedimentary and volcanic sequences (Brook et al., 1988). Many massifs have similar stratigraphy: a lower section of basaltic lava with intercalated siliceous and/or calcareous mudstones, overlain by basaltic lava and sub-volcanic intrusives (Isaac et al., 1996). Low-angle faults and shear zones are pervasive, owing to the structural complexity (Larsen and Spörli, 1989), and are most common with abundant mudstone (Isaac et al., 1994). An Early Cretaceous to Paleocene age is given based on foraminifera within intercalated sediments (Hollis and Hanson, 1991), and a dominant Paleocene age from radiometric K-Ar dating (Brothers and Delaloye, 1982). However, a cluster of younger radiometric ages of 31-24 Ma from tholeiites (Whattam et al., 2005), and a $32 \mathrm{Ma}$ age from an ophiolite gabbro sample (Whattam et al., 2006), suggest a younger age for oceanic crust.

Tupou Complex consists of indurated sandstone and mudstone, bedded conglomerate and some siliceous mudstones and radiolarian chert (Brook and Hayward, 1989). Fauna collected from a single concretion give an Early Cretaceous age (Hay, 1975), although this could be reworked, as conglomerate clasts are predominantly dervied from Mount Camel terrane (Isaac et al., 1996).

Mangakahia Complex comprises four main units (Hay, 1960). Late Cretaceous flysh (Whatuwhiwhi Formation), Late Cretaceous siliceous mudstone (Whangai Formation), Late Cretaceous-Paleocene muddy limestone, and Paleocene-early Eocene non-calcareous mudstone (Hukerenui mudstone). Flysch are suggested to have accumulated in outer shelf conditions, whereas the other units accumulated in bathyal-abyssal paleodepths (Hayward et al., 1989).

Motatau Complex comprises middle Eocene to early Oligocene outer shelf-middle bathyal calcareous Omahuta sandstone and Taipa mudstone (Hay, 1960; Isaac et al., 1994), and late Oligocene to early Miocene micritic limestones of the Mahurangi Limestone (Carter, 1969). Shear zones between fault blocks contain lenses of Mahurangi Limestone, and it is also deformed beneath the Northland Allochthon on the east coast of Northland (Rait, 2000; Spörli and Harrison, 2004). 


\subsubsection{Late Cretaceous-Paleocene passive margin}

Cessation of rifting, and subsequent transition into passive margin conditions via thermal subsidence were contemporaneous with the onset of seafloor spreading in the Tasman Sea at $80 \mathrm{Ma}$ (Gaina et al., 1998). Marine transgression deposits covered rift basins, but some basement highs remained uncovered (Bache et al., 2012a,b; Strogen et al., 2017). Tectonic reconstructions infer northwest New Zealand lay on a marine margin north of proto-New Zealand (Sutherland et al., 2001), gradually giving way to bathyal conditions with no discernible basin margins (Isaac et al., 1994; Herzer et al., 1997).

No autochthonous Paleocene rocks outcrop in Northland (Figure 1.2). However, $54 \mathrm{~m}$ of Paleocene to early Eocene calcareous mudstone, shallow-water glauconitic sandy-limestone and sandstone unconformably overly Murihiku terrane in the Waimamaku-2 borehole in western Northland (Figure 1.2B and C) (NZ Petroleum Exploration Co Ltd, 1972). These are inferred to have accumlated around margins of a landmass that extended over southern, central and northern parts of Northland Peninsula based on reworked shallow-water Cretaceous fauna (Hornibrook et al., 1976; Hayward et al., 1989). A 191 m thick succession of limestone and calcareous sandstone and mudstone indicate progessive deepening during the early to middle Eocene (Hornibrook et al., 1976).

Transgressive sandstone and conglomerate facies unconformably overlie Jurassic coal measures at Waka Nui-1, which are in turn overlain by a 513 m thick Paleocene to Eocene succession of siltstone and mudstone (Milne and Quick, 1999), indicating marine flooding of the region during early Paleocene time (c. 62 Ma) (Sutherland et al., 2010; Baur et al., 2014). This succession is correlated to Turi Formation of Taranaki Basin (Stagpoole, 2011). Marine conditions have persisted to the present-day (Strong et al., 1999). Shelfal microfauna in Deepwater Taranaki wells Ariki-1, Tane-1, Wainui-1 in addition to observed clinoform and downlap reflector geometries on seismic reflection data, indicate the development of a southeast-northwest trending shelf margin nearby (Baur et al., 2014).

Reinga Basin was in deep-water bathyal conditions during the Paleocene, based on fossils in dredged mudstone (Browne et al., 2016). Marine shale in DSDP Sites 206 and 207 indicates bathyal conditions on Lord Howe Rise and New Caledonia Trough (Burns et al., 1973a,b). In addition, dredged Paleocene mudstone from eastern Lord Howe Rise indicates a low-energy, fully-marine bathyal environment by late Paleocene (59-56 Ma) time (Browne et al., 2016). In summary, there is evidence for progressively deeper-water conditions in northwestern New Zealand during the Paleocene. 


\subsubsection{Eocene-Oligocene Compressional Tectonics}

A large change in global plate motion in the Paleogene is manifest as the Emperor-Hawaii seamount chain bend (Steinberger et al., 2004; Sutherland et al., 2018). Geochronology shows that the Emperor-Hawaii bend initiated at, or just before $50 \mathrm{Ma}$, and was complete before $43 \mathrm{Ma}$ (Sharp and Clague, 2006). Changes in Pacific plate motion occurred at a similar time to cessation of Tasman Sea spreading (Gaina et al., 1998); a change in direction and rate of Australia-Antarctica spreading (Seton et al., 2012); and initiation of Australia-Pacific spreading south of New Zealand (Sutherland, 1995; Wood et al., 1996). In addition, volcanic rocks with subduction affinities have been dredged and dated from the Tonga-Kermadec forearc (52-48 Ma and 42-40 Ma) and the D'Entrecasteaux ridge (56-34 Ma) near New Caledonia (Duncan et al., 1985; Meffre et al., 2012; Mortimer et al., 2014a).

An Eocene obduction event in New Caledonia is widely inferred to mark subduction initiation to the east of New Caledonia (Crawford et al., 2003; Cluzel et al., 2012; Meffre et al., 2012). The onset of a convergent phase of tectonism during early Eocene (56-48 Ma) is manifest by the deposition of turbidites on top of Late Cretaceous and Paleocene lower bathyal sedimentary rocks in western New Caledonia (Maurizot, 2011). A thick sequence of Eocene sediment was deposited as deformation occurred, culminating in emplacement of ultramafic (Peridotite Nappe), mafic (Poya Terrane) and sedimentary allochthons during the middle-late Eocene (44-34 Ma) (Aitchison et al., 1995; Cluzel et al., 2001, 2006). Highpressure, low-temperature blueschist metamorphism in New Caledonia peaked at $44 \mathrm{Ma}$, and exhumation was complete by c. $34 \mathrm{Ma}$ (Baldwin et al., 2007).

A changing tectonic regime during the late Eocene is consistent farther south with movement along the Taranaki Fault, which is considered antithetic to the Tonga-KermadecHikurangi subduction zone (Holt and Stern, 1994; Stagpoole and Nicol, 2008). Precursory deformation is marked by thick sediment accumulation within isolated faulted sub-basins derived from Mesozoic basement in the uplifted hanging wall block of the fault (Palmer and Andrews, 1993; King and Thrasher, 1996). Far-field Eocene subsidence is documented to the south across Taranaki and Deepwater Taranaki basins (Stern and Holt, 1994; Baur et al., 2014).

Sedimentary and volcanic allochthons were emplaced in Northland and eastern North Island during late Oligocene to early Miocene (30-20 Ma) (Rait et al., 1991; Malpas et al., 1992; Isaac et al., 1994; Herzer, 1995; Herzer et al., 1997; Rait, 2000; Mortimer et al., 2003; Sutherland et al., 2009; Bache et al., 2012b). Emplacement age is constrained by the minimum age of strata beneath the allochthon, and the maximum age of strata above the allochthon. Drilled allochthonous strata at Waimamaku-2 range in age from Late Cretaceous-middle Oligocene (66-30 Ma), suggesting an emplacement at least during early Oligocene (Figure 
1.2C) (Hornibrook et al., 1976). Mahurangi Limestone is deformed beneath the allochthon in eastern Northland, and are of latest Oligocene to earliest Miocene age, indicating emplacement at $25 \mathrm{Ma}$ (Rait, 2000). Overlying autochthonous Waitemata Group sediments have been dated as Waitakian-Otaian (late Oligocene-early Miocene), constraining the upper age to 20 Ma (Hayward et al., 2001; Shane et al., 2010).

There is little to no evidence for late Eocene compression offshore or onshore Northland, and outcrop rocks suggest deposition in a relatively quiescent tectonic regime (Hayward et al., 1989; Isaac et al., 1994, 1996). Eocene to late Oligocene Te Kuiti Group unconformably overlies Permian to late Jurassic basement, and comprises Kamo Coal Measures, Ruatangata Sandstone, Mangapa Mudstone and Whangarei Limestone. Where fully developed, Kamo Coal Measures consists of basal siliceous mudstone and non-marine to marginal-marine carbonaceous shales and mudstone. Coals are low-medium rank due to burial beneath a former thick cover of Northland Allochthon (Isaac et al., 1994; Edbrooke et al., 1998). Caples Terrane basement is unconformably overlain by late Eocene inner-middle shelf, medium-to-fine grained, quartzose and glauconitic Ruatangata Sandstone, which is succeeded conformably and gradationally by middle shelf to upper bathyal calcareous Mangapa Mudstone in northern Northland (Brook et al., 1988; Isaac et al., 1994, 1996). Whangarei Limestone comprises glauconite, and bioclasts of bryozoa, molluscs, and foraminifera, which accumulated in shelfal paleodepths during the Oligocene (Evans, 1989). A $189 \mathrm{~m}$ thick bathyal limestone succession, correlated to Tikorangi Formation of Taranaki Basin, represents the Oligocene period offshore at Waka Nui-1 (Milne and Quick, 1999; Stagpoole, 2011).

Convergence is observed to propagate southwards towards New Zealand, with signals of deformation recorded across the Tasman Sea. Seismic stratigraphy tied to DSDP boreholes indicate reverse faulting and folding on Lord Howe Rise (49-37 Ma) and in New Caledonia Trough (44-36 Ma) (Sutherland et al., 2017). Dredge samples reveal that folded strata have Paleocene to Eocene ages and were deposited in passive deep-water bathyal environments in Reinga Basin (Browne et al., 2016). Faunal assemblages date uplift and folding to 53-48 $\mathrm{Ma}$, and the end of reverse faulting is inferred from undeformed shallow-water bioclastic limestones that have subsided $>1 \mathrm{~km}$ since 36-30 Ma (Sutherland et al., 2017). Widespread Eocene uplift during reverse faulting and large-magnitude subsidence is referred to as the Tectonic Event of the Cenozoic in the Tasman Sea area (TECTA) (Sutherland et al., 2017). 


\subsubsection{Neogene Arc}

The active Australia-Pacific plate boundary between North Island and Tonga is characterised by west-dipping subduction and back-arc extension (Stern et al., 2006). There is a general agreement that the modern Tonga-Kermadec system evolved from a boundary lying near Norfolk Ridge in the Eocene (Sutherland et al., 2018), despite a variety of differing models proposed to explain the numerous Eocene-Miocene arcs and back-arc basins between the Tonga-Kermadec trench and Norfolk Ridge (Herzer et al., 2000; Crawford et al., 2003; Cluzel et al., 2006; Schellart et al., 2006; Mortimer et al., 2007; Herzer et al., 2009; Sutherland et al., 2010).

Hikurangi-Northland subduction developed in response to local changes in plate boundary displacement rate and consequent linkage between subduction north of New Zealand and Alpine Fault formation farther south during early Miocene (c. 23-20 Ma) time (Ballance, 1976; Rait et al., 1991; Kamp, 1999; King, 2000a; Stern et al., 2006). West of the plate boundary, the subducted plate and associated mantle flow begins to drive deformation as opposed to upper plate shortening (Reyners et al., 2007); coupled with slab roll-back, this may induce back-arc extension and volcanism (Giba et al., 2010). Relics of early Miocene arc-type volcanism are located on both sides of Northland (Figure 1.2) (Herzer and Mascle, 1996; Hayward et al., 2001).

Back-arc extension preferentially occurs in young subduction zones, with most extension occuring within $50 \mathrm{Ma}$ of inception (Gurnis et al., 2004). Geophysical and geochemical data indicates that Norfolk Basin opening was concurrent with South Fiji Basin opening (Herzer et al., 2000; DiCaprio et al., 2009), dated between 36 Ma (Malahoff et al., 1982) and 25-22 Ma (Crawford et al., 2003; Mortimer et al., 2007). Dredge samples from Three Kings Ridge indicate a 22-19 Ma age for the cessation of arc activity north of New Zealand (Mortimer et al., 1998). Back-arc extension did not reach as far south as Taranaki until c. 12 Ma (Herzer et al., 2009; Giba et al., 2010).

Subduction and back-arc processes are accompanied by arc-related calc-alkaline volcanism that occurs in high-volume to the west (Herzer, 1995), and through the axis of Northland Peninsula (Hayward, 1993; Hayward et al., 2001). Seismic stratigraphy tied to radiometric ages of onshore calc-alkaline volcanics date volcanic activity between 25-11 Ma, although there is no obvious geographical eruptive trend (Herzer, 1995; Hayward et al., 2001). Potentially controversial Ar/Ar dating suggests volcanism and plutonism began at least 2 Ma earlier at $27 \mathrm{Ma}$ (Whattam et al., 2005, 2006; Nicholson et al., 2007).

Northland Miocene stratigraphy includes subaerial and submarine volcanism, and erosion of the Northland Allochthon (Isaac et al., 1994). Onshore Miocene volcanics and 
allochthonous sheets locally interfinger with Waitemata Group turbidites in a depocentre southeast of Northland Peninsula (Spörli, 1989; Spörli and Rowland, 2007), indicating deposition in a tectonically active basin (Waitemata Basin) from 21-16 Ma (Kamp and Furlong, 2006). Fauna within basal Waitemata Group sediments indicate initial shallow-water conditions followed by subsidence to bathyal depths in the earliest Miocene; coincident with development of the Northland Arc (Hayward, 1993; Spörli and Rowland, 2007). Marine conditions during the Miocene led to deposition of deep-water marls with interbedded calcareous claystone and sandstone beds and minor volcanic clasts of Mohakatino and Ariki formations (Milne and Quick, 1999).

Arc activity records a progressive shift towards the southeast during the Miocene. A change in volcanic orientation is observed at $12 \mathrm{Ma}$, corresponding to middle-late Miocene Mohakatino volcanism in Taranaki Basin (Hayward, 1993) and middle Miocene-Recent lowpotash andesitic volcanism onshore (Stern et al., 2006). Gradual southward migration of volcanism has been attributed to progressive steepening and/or southeast rollback of the subducting Pacific Plate since $12 \mathrm{Ma}$ (Giba et al., 2013). Geophysical analysis suggests that the subduction zone has rotated clockwise $\sim 80-90^{\circ}$ to its present-day location since the Neogene (Walcott, 1987, 1989). The youngest phase of back-arc rifting is manifest by the opening of Havre Trough and Central Volcanic Region in the late Miocene to Pleistocene (Stern, 1985; Wright et al., 1996). 


\section{Chapter 2}

\section{Seismic Interpretation}

\subsection{Seismic Data}

Seismic data in this study encompass stacked, multi-channel 2D seismic reflection data, which were acquired across multiple petroleum exploration and prospecting licences. The dataset comprises 161 2D seismic lines with a total line length of $\sim 22,500 \mathrm{~km}$, covering a surface area of approximately $320,000 \mathrm{~km}^{2}$ from the Challenger Plateau in the south, to the southern Norfolk Ridge in the north (Figure 2.1).

Acquisition campaigns in the study area span 14 years and have a range of acquisition and processing parameters, data quality, amplitude and frequency content that vary across different surveys (see Appendix B.1 for survey acquisition parameters). The open-source New Zealand Petroleum and Minerals (NZP\&M) dataset contains the most recent processed versions of each survey, and is consequently the best possible compilation of available seismic data without undertaking any reprocessing (Sutherland et al., 2012).

Eight surveys are included in this study: GS82 (GECO NZ, 1982), 114 (Marshall et al., 1994), CNL (95a, 95b, 98) (Ministry of Economic Development, 1993, 1996), DTB-01 and ATB-10 (Ministry of Economic Development, 2011), REI09 (Ministry of Economic Development, 2009a), Strat09 (Ministry of Economic Development, 2009b) and TL-01. ATB-10 and DTB-01 surveys are located south of the central area of interest, however, are added for further chronostratigraphic constraints on seismic-stratigraphic correlations between basins, and its record of shelf environments. 


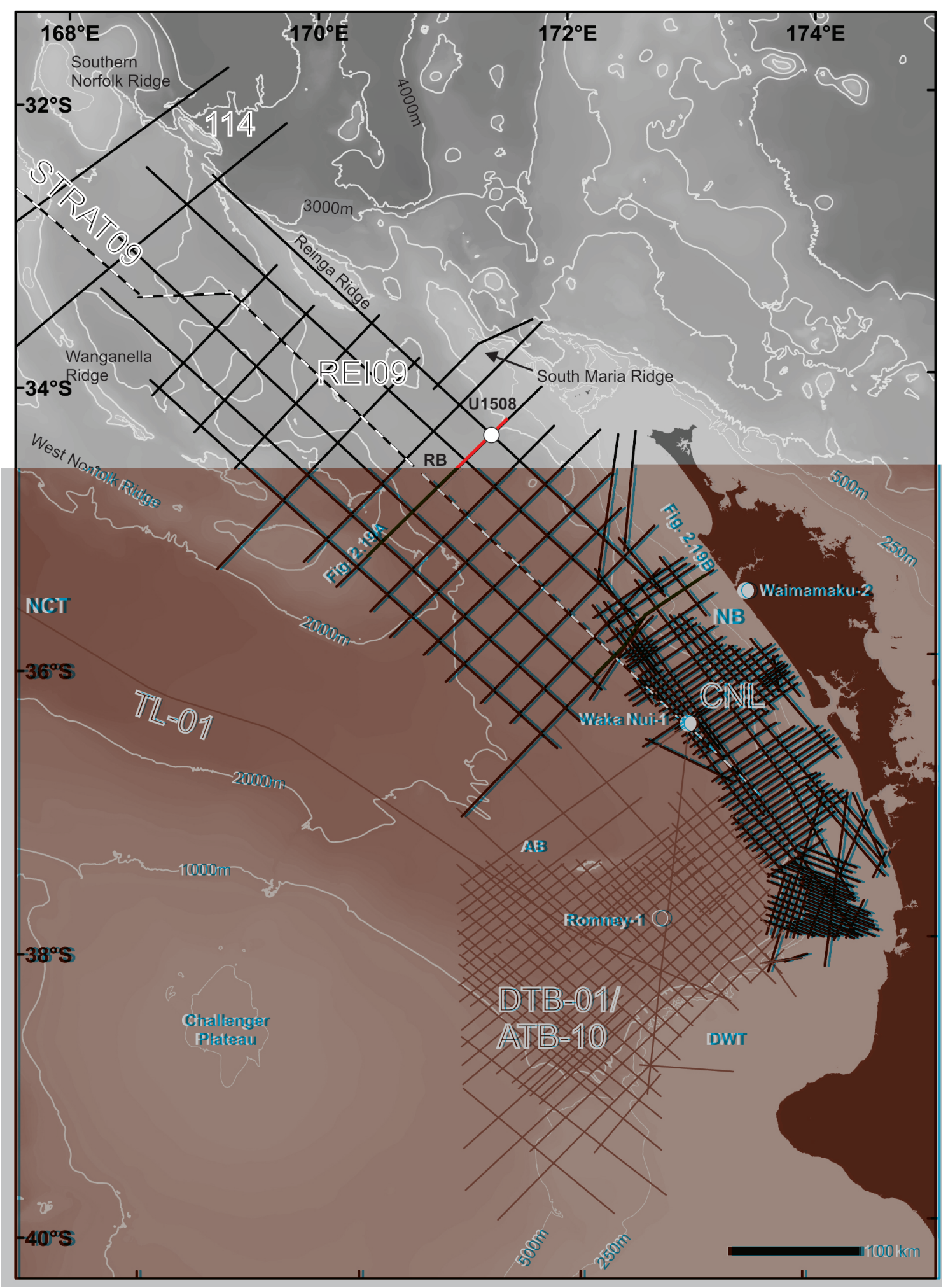

Figure 2.1: Bathymetric overview map (Mitchell et al., 2012) of northwest New Zealand showing the location and distribution of seismic (lines) and borehole (points) data used in this study. AB, Aotea Basin; DWT, Deepwater Taranaki; NB, Northland Basin; NCT, New Caledonia Trough; RB, Reinga Basin. Primary and secondary 2D seismic data are shown in black and grey, respectively. CNL survey comprises CNL95a, CNL95b and CNL98. Red lines show the location of Figures 2.19A and 2.19B in Section 2.4. 
Overall, the data are good quality, although there are some problems. Multiple energy is visible on a number of lines, particularly in the CNL surveys, which affects deeper sections, but does not impede interpretations (Uruski et al., 2004). Reflectivity becomes incoherent, particularly in the CNL and REI surveys, near volcanic and allochthonous edifices, making loop-ties between basins difficult.

To ensure that phase convention was consistent across the dataset, mis-ties and phases were analysed and adjusted using modules within the SeisWare software package. Phase rotation was applied to the 114 survey to change the polarity from reverse to normal. The REI09 survey was chosen as the master reference survey for loop-ties between basins, as it has regional extent, good quality and sufficient tie points with surrounding surveys. Bulktime shifts were performed on Strat09 lines to align seismic target events (seabed reflections) and systematically match data across Reinga Basin. The seismic two-way-time to the seabed was greater by $20 \mathrm{~ms}$ within the DTB-01 survey compared to other seismic data (Uruski, 2007). DTB-01 data were therefore bulk-shifted upwards by $20 \mathrm{~ms}$ to give consistent times throughout the study area.

Seismic data used in this study use the SEG normal polarity convention. Positive deflection of the centre of the Ricker wavelet indicates an increase in acoustic impedance across a geological boundary, and negative deflection indicates the opposite i.e. a decrease in acoustic impedance. In figures of this thesis, a black loop indicates a positive polarity (peak) and a white loop indicates a negative polarity (trough). To asses consistency between surveys, the seabed reflection is mapped between surveys; the arrival should always exhibit a positive amplitude, as the density of rock is always greater than water (Figure 2.2).

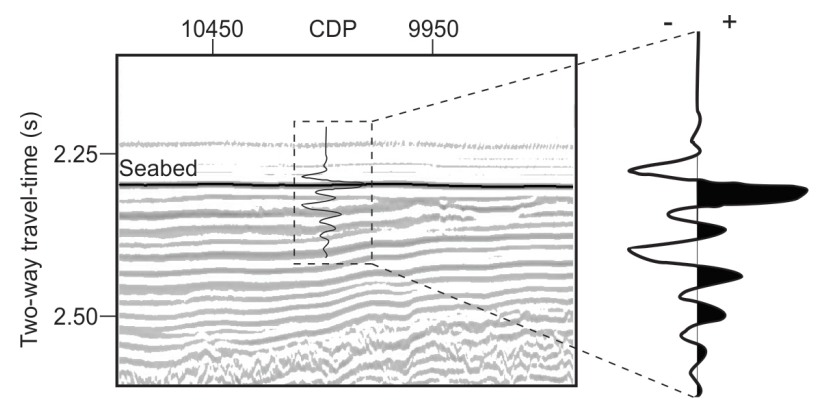

Figure 2.2: Polarity convention used in this study (SEG normal). Seabed wavelet is extracted from seismic line REI09-012 in Reinga Basin. A black loop indicates a positive amplitude (peak), whilst a white loop indicates a negative amplitude (trough). 


\subsection{Methodology}

Seismic stratigraphy provides a framework for interpretation and modelling depositional setting, facies, geological history and lithologies away from control points (Vail et al., 1977; Vail, 1987; Catuneanu et al., 2009, 2011). Stratigraphic relationships are identified within seismic reflection data through genetically-related stratigraphic units bound by surfaces of erosion, non-deposition or correlative conformities (Van Wagoner et al., 1987; Catuneanu, 2006).

Seismic reflections approximate isochronous surfaces but lateral variability may occur across different depositional environments and hence incorporate a range of lithofacies units. Spatial variations in sedimentary architecture, lithofacies, and acoustic impedance character $(z=\rho v$, where $\rho=$ density of the material; and $v=$ velocity of the material) are expressed in seismic data by reflection geometry (Figure 2.3A) and character (Figure 2.3B). Such seismic facies are defined as groups of seismic reflections whose parameters (configuration, continuity, frequency and interval velocity) differ from adjacent groups (Mitchum Jr et al., 1977a; Sangree and Widmier, 1979).

Seismic reflection packages that are isochronous and comprise genetically-related depositional systems can be grouped into depositional sequences, or systems tracts (Mitchum Jr et al., 1977b; Van Wagoner et al., 1987). However, seismic units are identified using the termination of seismic reflectors: onlap, downlap, toplap and truncation (Figure 2.3A), which indicate an erosional hiatus or structural disruption and unconformities (Vail et al., 1977). Distinguishing the position of the termination (i.e. above or below) provides insight into the initiation or cessation of the corresponding depositional unit, but these may be diachronous between sedimentary basins. Basic observations lead to the sequence stratigraphic framework defined by stacking patterns and bounding surfaces, hence this approach adopts a model-independent workflow (Catuneanu et al., 2009, 2011).

Several seismic facies may be found within a single sequence, with particular distributions, geometry and thickness pertaining to different depositional regimes (Figure 2.3B; Sangree and Widmier 1979). Knowledge of the spatial distribution and correlation of seismic facies with information from rock data (e.g. sedimentary facies or geophysical properties) allows geological information to be mapped into adjacent areas. Where this is possible, all surfaces and seismic facies may be age, depth and lithologically constrained by dredge and borehole data. 

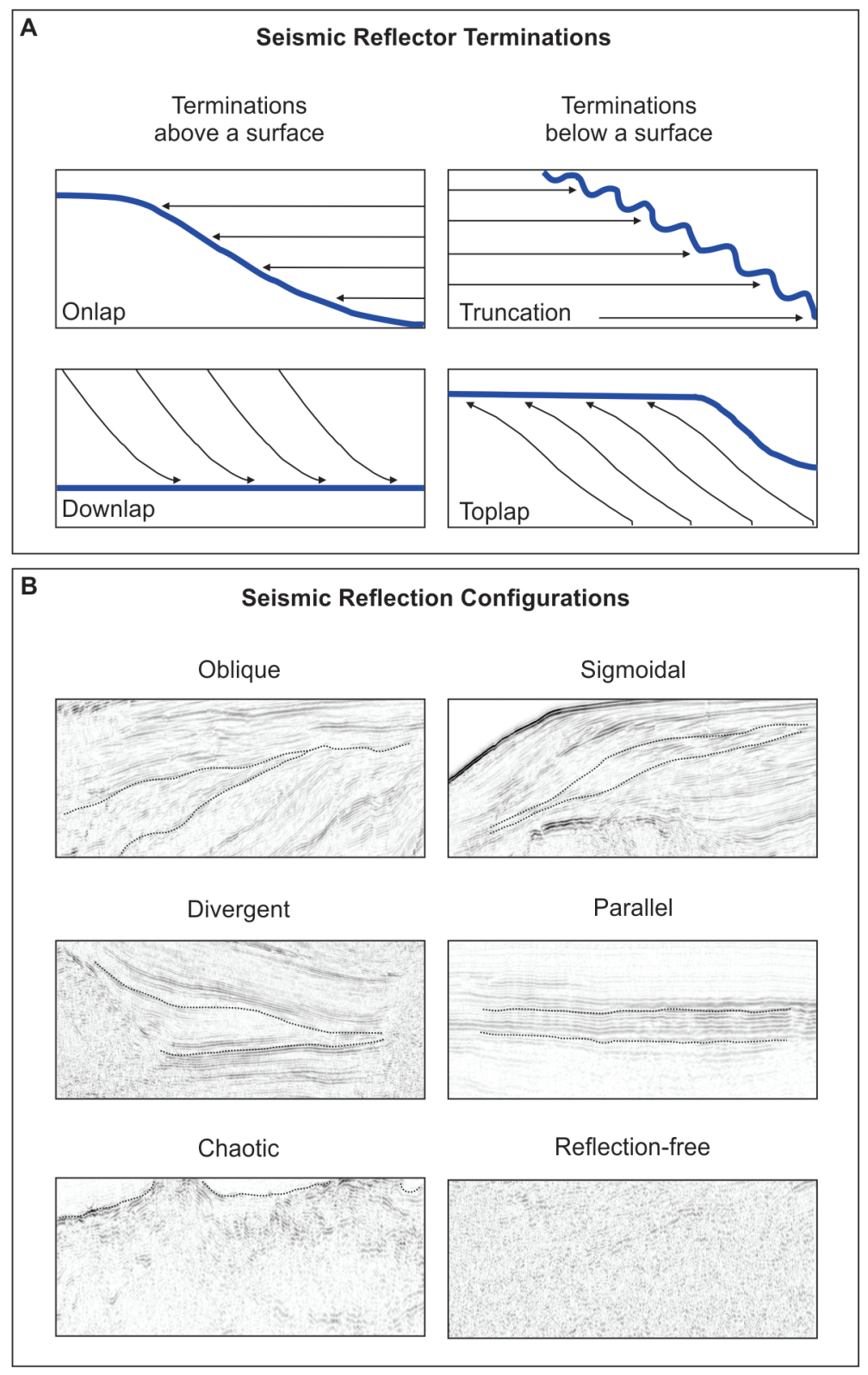

Figure 2.3: (A) Schematic stratal terminations that occur above or below a stratigraphic surface in seismic reflection profiles (from Catuneanu et al. 2009; after Mitchum Jr and Vail 1977). Interpreted horizons in this study are represented by the blue surface, based on the relationship to over or underlying strata (black arrows). (B) Typical reflection configurations (after Sangree and Widmier 1979) seen on seismic reflection data in this study.

Changes in the geometric character of strata and identification of key bounding surfaces can determine the chronological order of basin fill and erosional events. Stratal stacking patterns respond to changes in rates of sedimentation, base level and/or the degree of tectonism (Catuneanu et al., 2009). Each pattern defines a particular type of deposit (i.e. transgressive and regressive) with a distinct geometry and, therefore, can identify different depositional settings. For example, where rates of base sea level rise outpace sedimentation rates, seismic reflector configurations will onlap (Van Wagoner et al., 1987). 
It is important to consider the scale of observation in defining a seismic stratigraphic framework. Outcrop and well-log data support high-resolution sequence stratigraphic interpretations, whereas seismic data support lower-resolution interpretation. Given the data set used in this study comprises seismic data, the concept of a hierarchy is used to define sequence-stratigraphic units and their relative significance at different levels of observation (Catuneanu, 2006; Catuneanu et al., 2011). Where there is a lack of geochronological control, sequences should be referred to in a relative sense, and relative stratigraphic significance is based on criteria observed on seismic data, based on the degree of reflector termination. Within this hierarchy, the most important sequence is first-order (e.g. tectonically generated sequences), which are referred to herein as a mega-sequence, and may be subdivided into a series of second-order sequences (e.g. magnitude of onlap associated with changing sea level), and so on (Catuneanu, 2006). Increasing order reflects an increasing frequency of events within the stratigraphic record, but where there is a lack of lithological data, only first-order sequences may be identified. 


\subsubsection{Application to Reinga and Northland basins}

In adopting the model-independent framework of Catuneanu et al. (2009), observations of bounding surfaces, strata termination and stacking patterns lead to the construction of a seismic-stratigraphic framework. If boundaries to sedimentary packages are a result of a firstorder change in basin structure, or second-order change in sea level, then a contrast in physical rock properties (i.e impedance contrast) should exist across that boundary and yield a useful geophysical marker. Units defined on this basis are considered informal lithostratigraphic units by the North American Commission on Stratigraphic Nomenclature (2005), unless they are tied to borehole, dredge or outcrop data. This study is the first to do so in Reinga Basin.

Previous seismic interpretations have defined a series of seismic-stratigraphic units, based on sequence-stratigraphic relevance, inferred to relate to first-order tectonically-driven basinfilling phases (Figure 2.4). Initial mapping was independent of currently accepted seismicstratigraphic units. However, broad correlation to horizons of Bache et al. (2012a,b) has led to adoption, and modification of their nomenclature. Seismic-stratigraphic boundaries (unit top) are named with prefix 'UB', and the underlying seismic unit is given prefix ' $U$ ' (Figure $2.4)$.

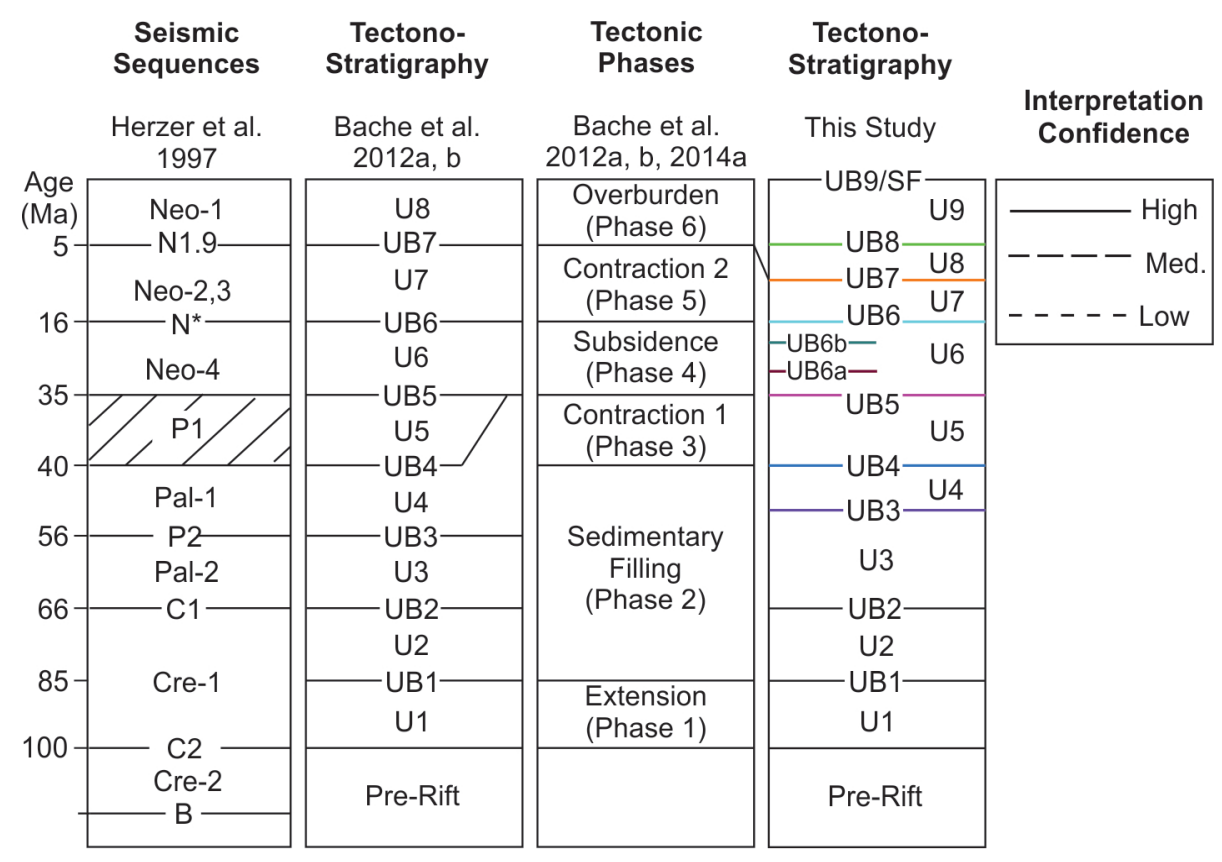

Figure 2.4: Seismic-stratigrapic framework and units for Reinga and Northland basins from previous studies (Herzer et al., 1997; Bache et al., 2012a,b), corresponding to local and regional tectonic phases (Bache et al., 2012a,b, 2014a). Tectonostratigraphic interpretation differs slightly in this study. Coloured surfaces represent mapped horizons and units and adopt the nomenclature of Bache et al. (2012a,b). A confidence scale used in the seismic interpretation is shown. 


\subsection{Results of seismic interpretation}

Eight seismic horizons were interpreted across the area, with a focus on the Eocene to Miocene geology of the offshore northwestern region of New Zealand. These include the seabed and major seismic-stratigraphic boundaries: reflectors UB3 to UB8, sub-unit boundaries UB6a and UB6b, erosion surfaces, volcanic and allochthonous edifices. Nomenclature for seismicstratigraphic units (U) and bounding surfaces (UB) are modified from Bache et al. (2012a,b) (Figure 2.4). Differences to tectonostratigraphy of Bache et al. (2012a,b) are the definition of UB3 from their recognised equivalent, the addition of UB8 and U9, and sub-units within U6 (U6a and U6b), which are top-bound by UB6a and UB6b, respectively.

Interpreted horizons on REI09 and Stratus lines were loop-tied back to a primary dip line (REI09-012) and primary strike lines (STRAT-004 and 005). Interpreted horizons on CNL lines were loop-tied to a primary dip line (CNL95a-034) and a primary strike line (CNL95a-017). These lines are near stratigraphic borehole control (U1508 and Waka Nui-1), where strata geometry changes should reflect a lithological change in the borehole, which in turn, provides an area of high-confidence for interpretation. In highly-tectonised areas away from stratigraphic control, a confidence scale for interpretation is adopted (Figure 2.4), and displayed on interpreted seismic sections throughout this thesis.

\subsubsection{Horizon Maps}

Regional interpretation of seismic horizons are presented here as a series of maps showing the two-way-time structure and distribution of major seismic-stratigraphic horizons, and the interval thickness (in two-way-time) between them. Grids were generated using the minimum curvature technique in SeisWare, with a $15 \mathrm{~km}$ interpolation. 

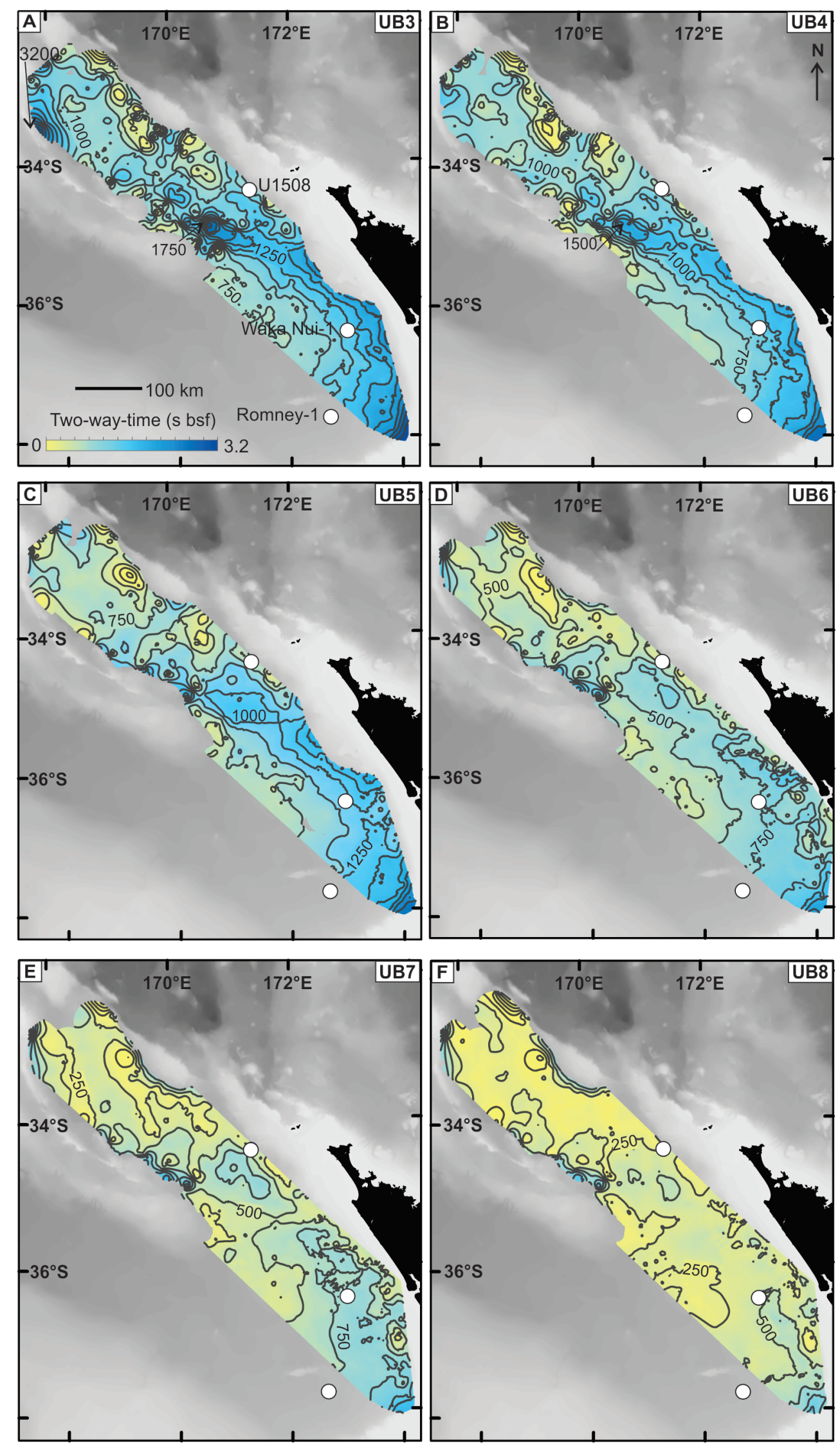

Figure 2.5: Two-way-time structure grids of horizons UB3-UB8. Contour interval is $0.25 \mathrm{~s}$. 

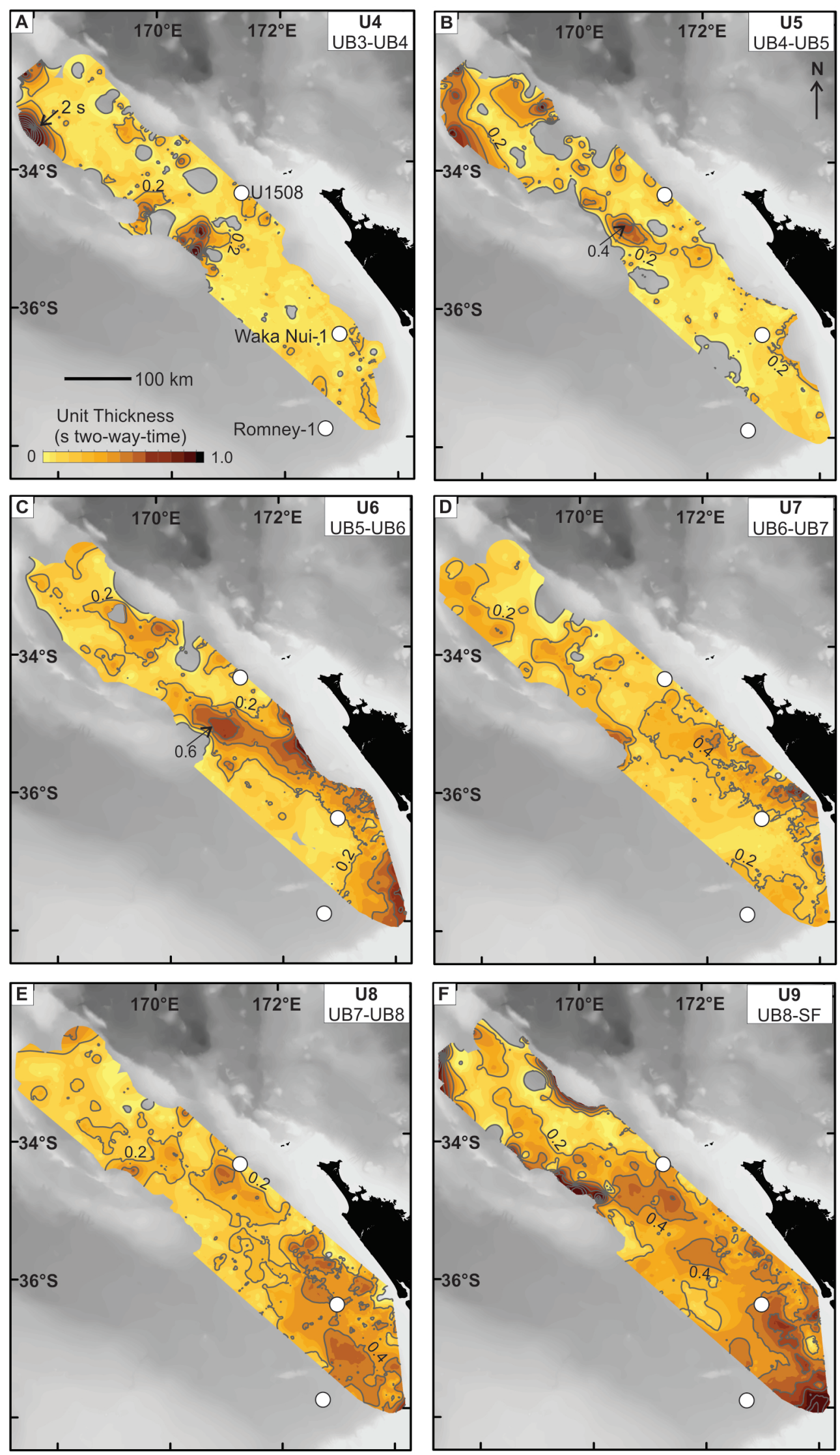

Figure 2.6: Two-way-time isopach grids of units U4-U9. Contour interval is $0.2 \mathrm{~s}$. 


\subsubsection{Horizon UB3 and Seismic Unit 4}

Horizon UB3 is the deepest seismic reflection within the time interval of interest. This horizon has regional significance for seismic stratigraphic correlation because it is easily mapped and recognised (Sutherland et al., 2019a). It is a prominent high-amplitude, positive polarity reflector that ranges from 1.5-5.5 s two-way-time in Reinga Basin and 3.0-3.5 s two-waytime in Northland Basin (Figure 2.5A). Lateral continuity of the reflector is high within both basins, it is conformable with reflectors above and below, and folded in Reinga Basin; but it is discontinuous, obscured and eroded near volcanic edifices and structural highs at basin margins (Figure 2.7). No angular discordance is observed in Northland Basin. It is a correlative conformity based on loop-ties from Reinga Basin to the Waka Nui-1 borehole.

Seismic Unit 4 (U4) is characterised by onlap relationships adjacent to a fold buttressed against West Norfolk Ridge (Figure 2.7). This observation is not recognised by Bache et al. (2012a,b), but UB3 can be confidently correlated across the fold near West Norfolk Ridge based on the high-amplitude seismic facies of overlying U4, and the continuous, parallel geometry of underlying reflections. U4 comprises conformable high-amplitude reflectors everywhere else, and are folded in northwest Reinga Basin.

$\mathrm{U} 4$ is predominantly thin ( $<0.2 \mathrm{~s}$ two-way-time), which is in agreement with the unit mapped by Bache et al. (2012a,b), but it is thicker ( $>0.5 \mathrm{~s}$ two-way-time) in central Reinga Basin, and along eastern Wanganella Ridge; where a maximum thickness of $2 \mathrm{~s}$ is observed (Figure 2.6A). Seismic facies contain high-amplitude parallel reflectors that: (1) are folded and faulted, (2) onlap western ridges, and (3) are undeformed. 


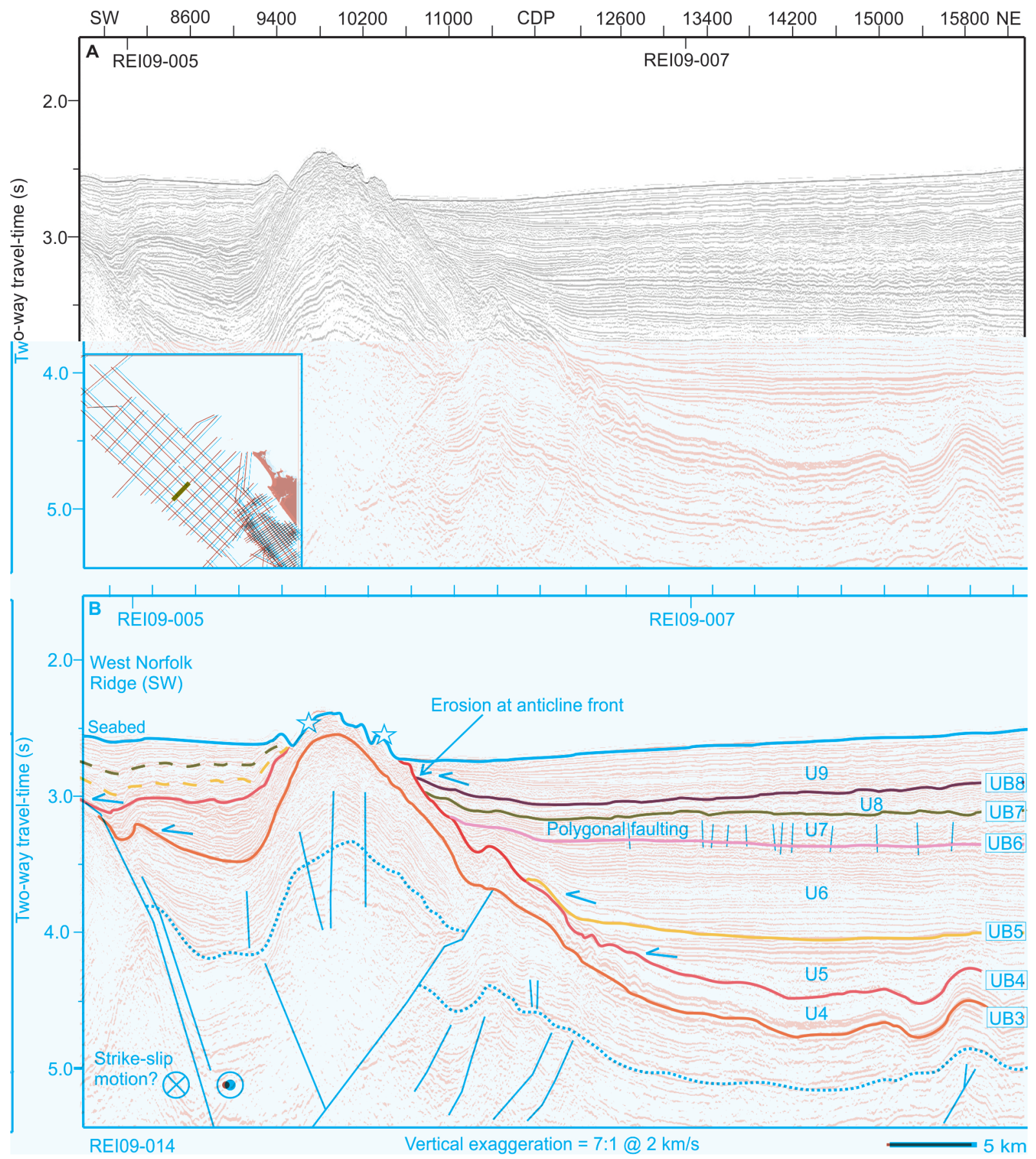

Figure 2.7: Uninterpreted (A) and interpreted (B) seismic reflection line REI09-014 showing stratal geometries in western Reinga Basin where units are faulted and folded. UB3 and UB4 are correlated across the fold based on seismic character of over and underlying reflections. Southwest facing arrows indicate onlap to West Norfolk Ridge and the fold in western Reinga Basin. UB6 and U7 strata are affected by small-offset polygonal faults. Faults are shown by black lines. Folded rocks exposed at the seabed were dredged by Bache et al. (2014c) and constrain the age of folding and uplift in western Reinga Basin (white star - see Section 3.2.1). Labelled and coloured surfaces represent the interpreted seismic-stratigraphic horizons and units in this thesis and are used in subsequent figures. 


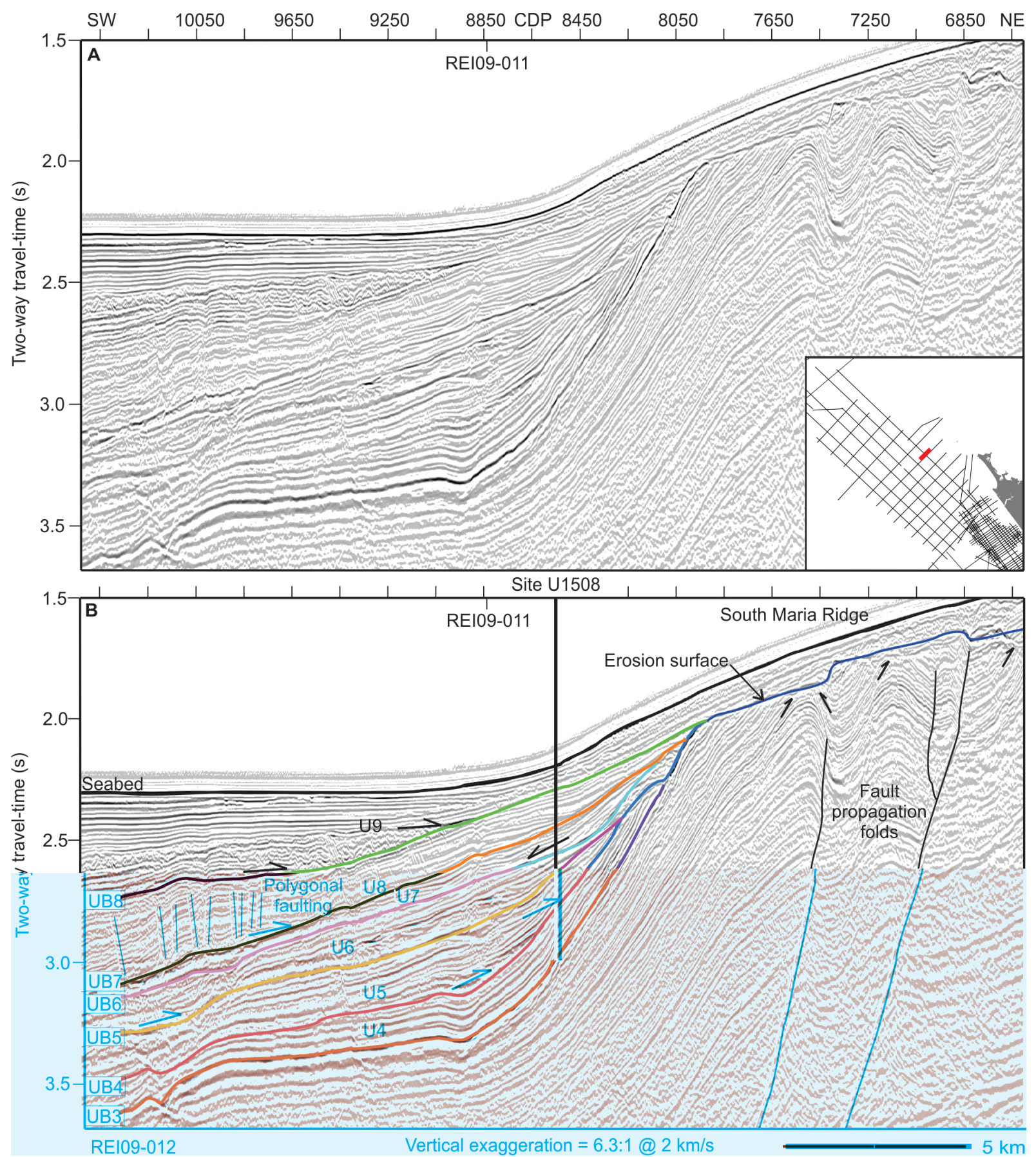

Figure 2.8: Uninterpreted (A) and interpreted (B) seismic reflection line REI09-012 and location of IODP Site U1508 (at CDP 8470) near South Maria Ridge. Northeast facing arrows indicate onlap to South Maria Ridge, southwest facing arrows indicate downlap, and upwards facing arrows indicate erosional truncation (wave ravinement surface). UB4 separates faulted and folded U4 from tilted onlapping reflectors of U5 against the basin slope. U6 strata onlap UB5 at a shallower angle compared to U5 reflectors. U7 strata downlap UB6. U8 and U9 strata progressively onlap the flank of South Maria Ridge. Small-offset polygonal faults are observed in U8. 


\subsubsection{Horizon UB4 and Seismic Unit 5}

Horizon UB4 is a moderate- to low-amplitude, positive polarity reflector that ranges from 1.6-4.7 s two-way-time across Reinga Basin, and 2.0-3.0 s two-way-time in Northland Basin (Figure 2.5B). It is an unconformity that separates underlying, parallel and folded strata from overlying, folded onlapping reflectors in Reinga Basin (Figure 2.8). Lateral continuity is preserved throughout a majority of the region, however, discordance is observed near the numerous folds found within the northwestern sector (Figure 2.9), and volcanic edifices in southeast Reinga Basin. No angular discordance is observed in Northland Basin. It is a correlative conformity based on loop-ties from Reinga Basin to the Waka Nui-1 borehole.

Seismic Unit 5 (U5) is stratigraphically variable across the study area. U5 is tilted and onlaps folded U4 strata in northwest Reinga Basin (Figure 2.8). Synclines highlight a localised change where reflectors are parallel and onlap folded UB4 (Figure 2.7). Significant divergence is observed along Wanganella Ridge where, underlying U4 reflectors appear relatively horizontal, and overlying reflectors dip at a similar angle to the present-day seafloor (Bache et al., 2012b).

U5 is locally thick in central Reinga Basin ( $>0.5 \mathrm{~s}$ two-way-time), but a maximum thickness of $1 \mathrm{~s}$ is observed along southwestern Reinga and Wanganella ridges (Figure 2.6B). This is interpreted to represent accumulation in sub-basins between structural highs, near areas of active sediment supply (Figure 2.9). Mapping of Bache et al. (2012a,b) shows U5 confined to sub-basins, here the unit is pervasive and represented by a thin $(<0.2 \mathrm{~s}$ two-waytime), parallel, moderate- to -low-amplitude seismic facies. 

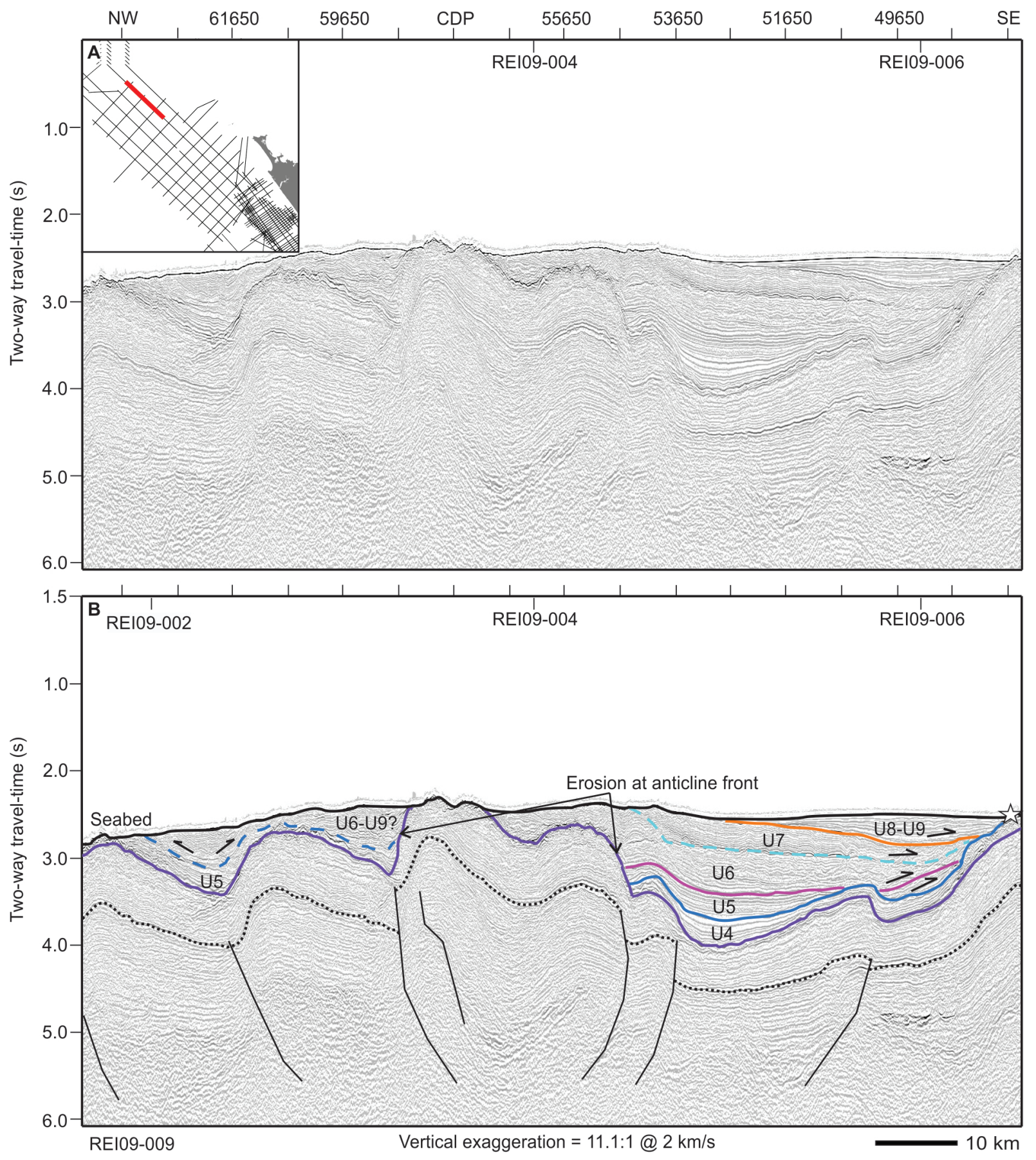

Figure 2.9: Uninterpreted (A) and interpreted (B) part of seismic reflection line REI09-009 showing faulting and folding on interpreted re-activated normal faults in northwestern Reinga Basin. Reflectors terminate and onlap against structural highs. U4 is tentatively interpreted to form in sediment-ponds between anticlines. Southeast facing arrows above UB6 indicate downlap (note the moderate confidence). All other arrows indicate onlap. Folded rocks exposed at the seabed were dredged by Bache et al. (2014c) and constrain the age of folding and uplift in northwestern Reinga Basin (white star - see Section 3.2.6). 


\subsubsection{Horizon UB5 and Seismic Unit 6}

Horizon UB5 is a moderate- to high-amplitude, positive polarity reflector that ranges from 1.5-4.0 s two-way-time in Reinga Basin (Figure 2.5C). An unconformity separates underlying tilted reflections of $\mathrm{U} 5$ from overlying parallel reflections that onlap at a lower angle (Figure 2.8). Discordance is observed near numerous folds (Figure 2.9) and where UB5 coincides with the base of volcanic edificies (Figure 2.10). UB5 is inferred to be coeval with an erosion surface that has truncated underlying folded strata near South Maria Ridge (Figure 2.8, 2.11).

In southeast Reinga Basin, northwest Northland Basin UB5 is a high-amplitude positive polarity reflector with high lateral continuity and ranges from 2.25-3.25 s two-way-time. Near the allochthonous edifices, overlying reflections of sub-units U6a and U6b downlap onto UB5 at shallow dips (Figure 2.11), highlighting a stratigraphic difference between the two basins. UB5 is high-amplitude in Northland Basin, with high lateral continuity, particularly in the west. Similar to southeast Reinga Basin, towards the east of Northland Basin this horizon coincides with local volcanic features, and overlying reflectors terminate against them with onlap configuration (Herzer, 1995).

Seismic Unit 6 (U6) strata are conformable throughout most of Reinga Basin, but are unconformable in places. U6 is confined to synclines, where sub-parallel reflectors onlap anticline margins in northwest Reinga Basin (Figure 2.9). U6 strata are unconformable, onlapping small-scale folds, and volcanic edifices in southeast Reinga Basin (Figure 2.10); and against the northeastern flank of Wanganella Ridge (Bache et al., 2012b). Localised downlap of U6 strata is observed near South Maria Ridge (see Section 2.3.12).

U6 is thin in most places ( $<0.2 \mathrm{~s}$ two-way-time), but is thicker in central Reinga Basin and near Northland Peninsula ( $\sim 0.6$ s two-way-time) (Figure 2.6C). Seismic facies contain reflectors with undulating relief where U6 is thickest in Reinga Basin. Sub-parallel, highto moderate-amplitude seismic facies coincide with U6a and U6b where U6 is thickest in Northland Basin. 

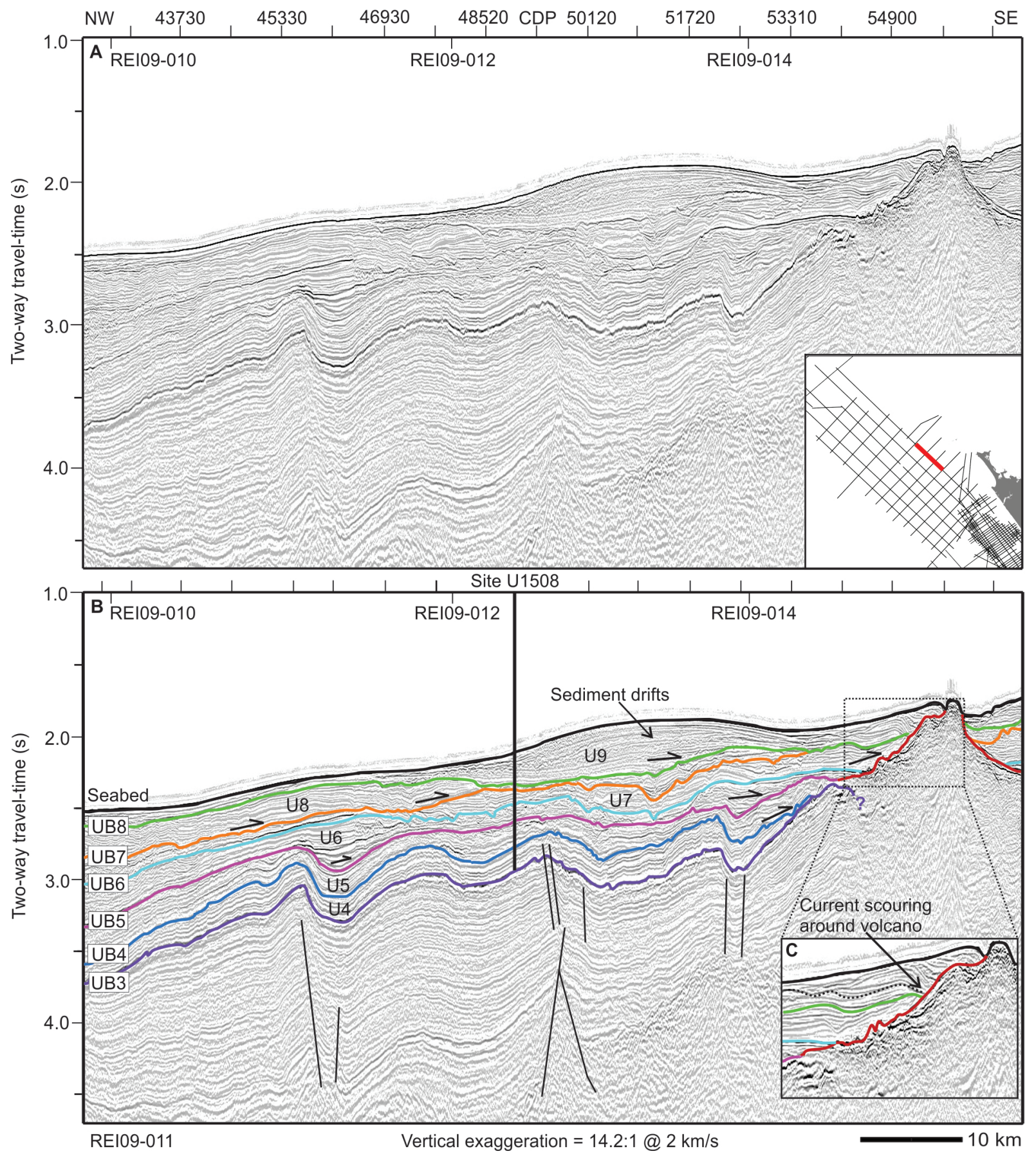

Figure 2.10: Uninterpreted (A) and interpreted (B) seismic reflection line REI09-011 showing stratigraphic relationships along strike from Site U1508. UB5 coincides with the base, and UB6 and U7 onlap the volcanic edifice, respectively. U6 strata are unconformable and onlap UB5 within a small-scale fold. (C) Enlargement of dashed box in $\mathbf{B}$ showing present-day seabed current scouring against the volcano which has a similar geometry to reflector UB8. 


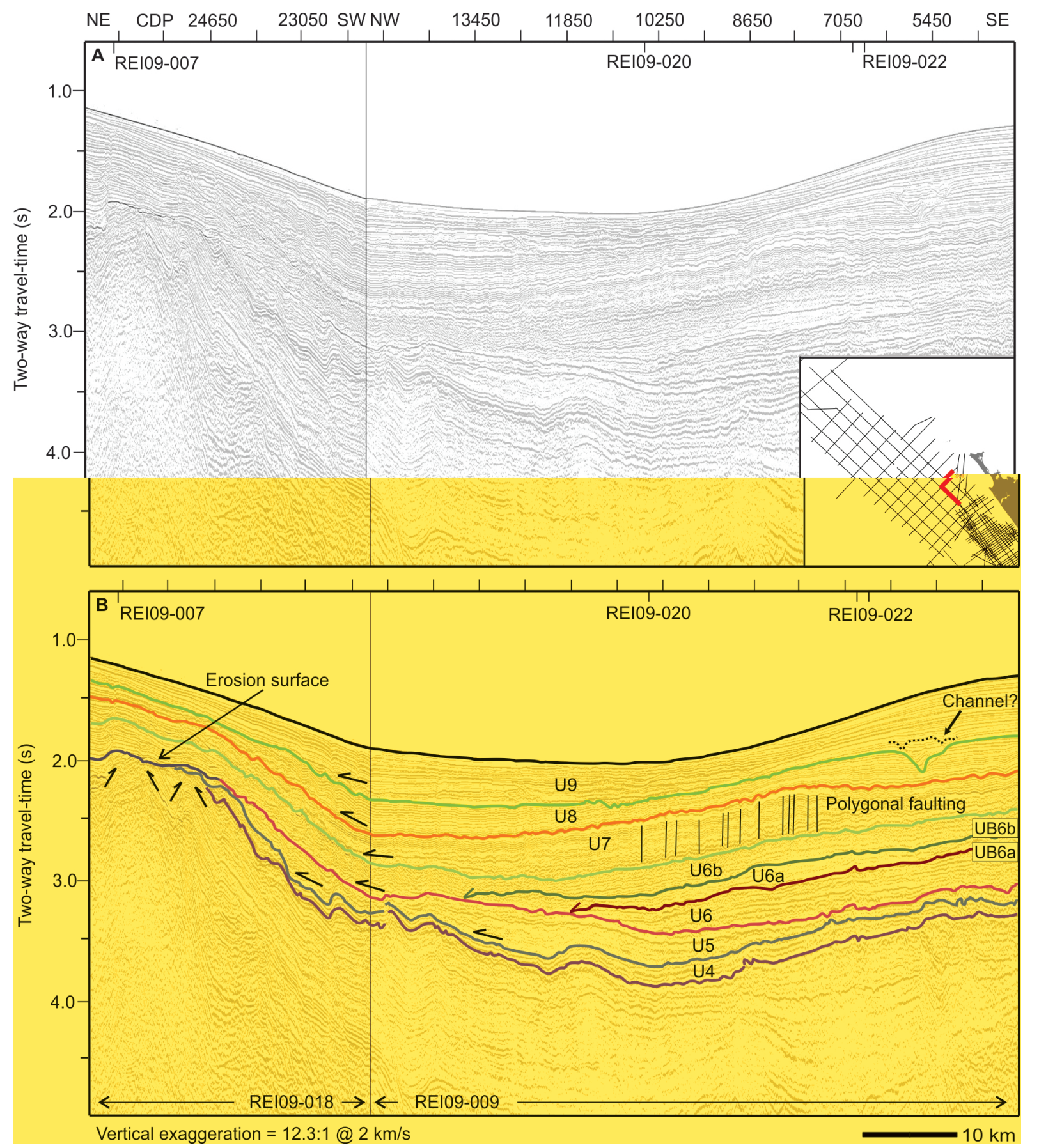

Figure 2.11: Uninterpreted $(\mathbf{A})$ and interpreted (B) composite seismic reflection section comprising lines REI09-018 (dip line) and REI09-009 (strike line) highlighting differences in U6 strata in southeast Reinga Basin. UB5 is coeval with a wave ravinement surface (dark blue) that truncates folded units U4 and U5 (indicated by upwards facing arrows). Two southeast-northwest trending fan features of U6a and U6b downlap the UB5 unconformity at shallow dips of $\sim 0.24^{\circ}$ (note vertical exaggeration). This location marks the northeastern extent of UB6a and UB6b. Small-offset polygonal faults affect U7 strata with undulating relief. A channelised feature is observed at the base of U9. 


\subsubsection{Horizon UB6a and Seismic Unit 6a}

Horizon UB6a is a moderate- to high-amplitude, positive polarity reflector that is identified in three sections of the study area, with lateral extent decreasing southwards (Figure 2.12A). Northernmost UB6a ranges from 0.8-3.2 s two-way-time, central UB6a ranges from 1.0-3.1 s two-way-time, and southern UB6a ranges from 0.9-2.2 s two-way-time. Seismic Unit 6a reflectors are continuous and exhibit downlap at an angle of $\sim 0.24^{\circ}$ thinning to the north and west (Figure 2.11). Towards eastern Northland Basin, the unit becomes blocky and downlap at a higher angle of $\sim 0.41^{\circ}$ (Figure 2.13).

\subsubsection{Horizon UB6b and Seismic Unit 6b}

Horizon UB6b is a moderate- to low-amplitude, positive polarity reflector that is identified in two sections of the study area (Figure 2.12B). Northern UB6b ranges from 0.4-3.2 s twoway-time and southern UB6b ranges from 0.6-1.7 s two-way-time; the horizon is not found in central Northland Basin. Seismic Unit 6b reflectors are semi-continuous and exhibit downlap at an angle of $\sim 0.16^{\circ}$ - similar to UB6a - thinning to the north and west (Figure 2.11). Towards the east of Northland Basin, the unit is continuous and downlap at a higher angle of $\sim 0.57^{\circ}$ (Figure 2.13).
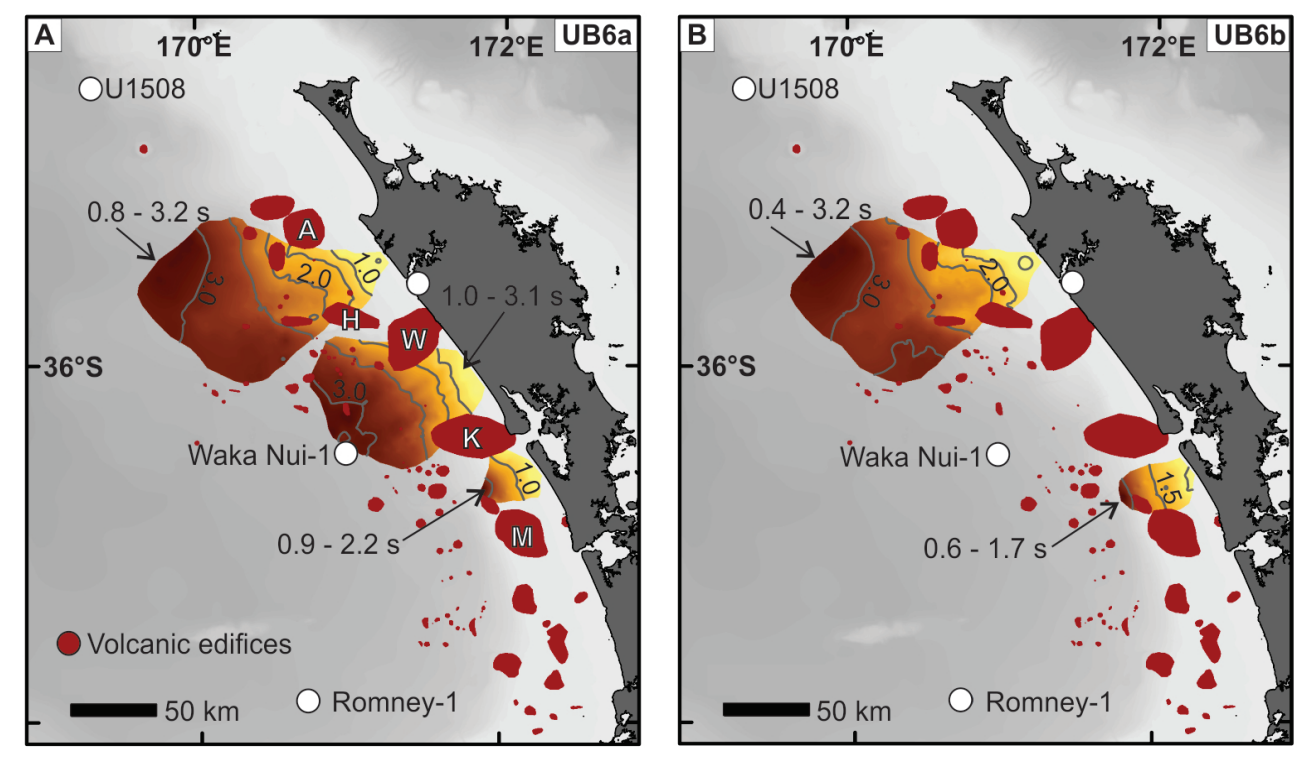

Figure 2.12: Two-way-time structure grids showing the distribution of horizons (A) UB6a and (B) UB6b. Maroon polygons are intra-U6 volcanic edifices; labels refer to established names given by Herzer (1995) and Hayward et al. (2001): A, Ahipara; H, Hokianga Massif; W, Waipoua Shield Volcanic Complex; K, Kaipara Shield Volcanic Complex; M, Manakau Shield Volcanic Complex (Section 2.3.13). Contour interval is $0.5 \mathrm{~s}$. 


\subsubsection{Horizon UB6 and Seismic Unit 7}

Horizon UB6 is a moderate- to high-amplitude, positive-polarity reflector ranging from 2.0 $3.7 \mathrm{~s}$ two-way-time across Reinga Basin (Figure 2.5D). It is an unconformity that separates underlying onlapping U6 strata, from overlying strata that downlap near South Maria Ridge (Figure 2.8), or onlap at a shallower angle elsewhere in Reinga Basin (Figure 2.11). UB6 amplitude increases near volcanic edificies (Figure 2.10), and U7 reflectors are typically higher amplitude than U6. Across Northland Basin, UB6 is low- to moderate-amplitude and ranges from $0.3-3.0 \mathrm{~s}$ two-way-time, where the horizon is chaotic, affected by polygonal faults and downlapped (Figure 2.13).

Seismic Unit 7 (U7) strata are conformable in most places, but are unconformable with onlap termination against Reinga Basin margins (Figure 2.11), and downlap termination in eastern Northland Basin (Figure 2.13). U7 strata are affected by small-offset polygonal faults in central (Figure 2.7) and southeast Reinga Basin (Figure 2.11); and near Northland Peninsula (Figure 2.13). U7 is thin ( $\leq 0.2 \mathrm{~s}$ two-way-time) across the mapped region (Figure 2.6D). Interval thickness is up to $0.6 \mathrm{~s}$ in sub-regions near Northland Peninsula. Where maximum thickness is observed, the seismic facies is represented by reflectors with undulating relief in Reinga Basin (Figure 2.11), and blocky reflectors in Northland Basin (Figure 2.13).

\subsubsection{Horizon UB7 and Seismic Unit 8}

Horizon UB7 is a moderate- to low-amplitude, negative polarity reflector with moderate continuity, ranging from 2.5 - $3.25 \mathrm{~s}$ two-way-time across Reinga Basin (Figure 2.5E). In contrast, UB7 is a moderate- to high-amplitude, positive polarity reflector that ranges from 0.2-3.6 s two-way-time across Northland Basin. Overlying reflectors onlap the UB7 unconformity across both basins.

Seismic Unit 8 (U8) is stratigraphically variable across the study area. It is conformable in most places, draping older units (Figure 2.9), but it is locally truncated by UB8 (Figure 2.10) in Reinga Basin. In northern Northland Basin, U8 contains a large-scale contourite/channel complex, and reflectors onlap near Northland Peninsula (Figure 2.13). U8 is thin $(<0.2 \mathrm{~s}$ twoway-time) across most of Reinga Basin, but is up to $0.4-0.6 \mathrm{~s}$ two-way-time thick proximal to southwestern South Maria Ridge and Northland Peninsula (Figure 2.6E). In these locations, U8 is affected by small-offset polygonal faults (Figure 2.8). 

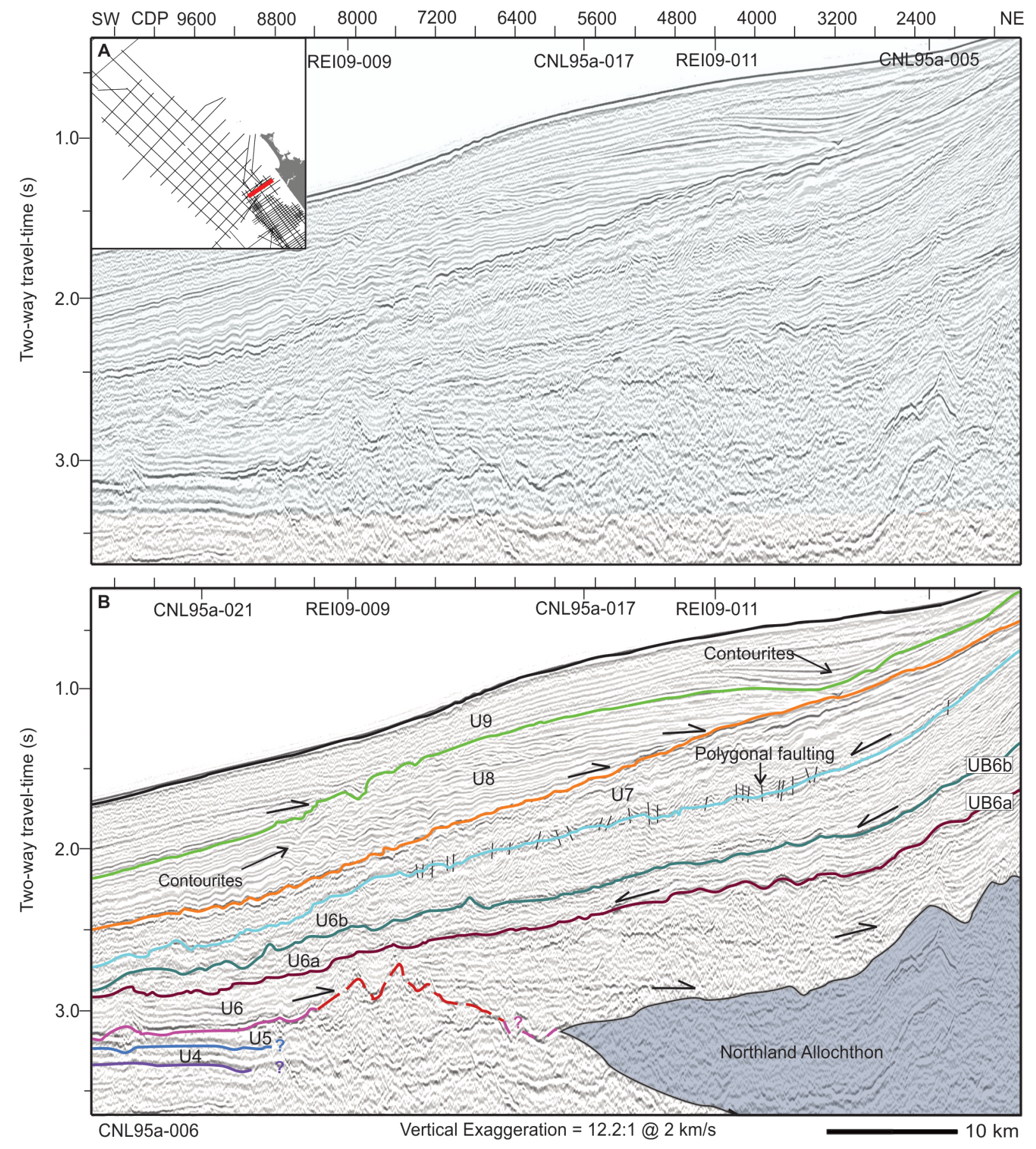

Figure 2.13: Uninterpreted (A) and interpreted (B) part of seismic reflection line CNL95a-006 showing down-dip stratigraphic relationships in Northland Basin. UB3 and UB4 are obscured by a volcanic edifice that is coeval with UB5 at its base. UB6a, UB6b and UB6 overlie the Northland Allochthon and downlap at higher angles near Northland to the northeast. U6 strata onlap the Northland Allochthon. UB6 and U7 are affected by small-offset polygonal faulting. UB7 and UB8 are onlap unconformities and overlying seismic units are characterised by contourites. 


\subsubsection{Horizon UB8 and Seismic Unit 9}

Horizon UB8 is a moderate- to high-amplitude, positive polarity reflector, ranging from 2.0$3.0 \mathrm{~s}$ two-way-time across Reinga Basin (Figure 2.5F). The horizon is a distinct basal onlap surface against the southwest flank of South Maria Ridge (Figure 2.8), however, there is little or no evidence of discordance elsewhere in Reinga Basin. UB8 is a high-amplitude reflector, ranging from 0.1-3.3 s two-way-time across Northland Basin, and is subtly onlapped near the Northland shelf (Figure 2.13).

Seismic Unit 9 (U9) contains conformable reflectors of undulating relief that passively drape U8 strata in most places. Variation is observed near the shelf and volcanic edifices where current-related deposits dominate the seismic facies. Scouring against volcanic edifices gives U9 a similar geometry to the present-day seabed (Figure 2.10). Contourites within U9 exhibit different character compared to U8 contourites near Northland Peninsula (Figure 2.13). U9 is variably thick across the mapped region (Figure 2.6F). The unit is thinnest $(<0.2 \mathrm{~s}$ two-way-time) in northwestern Reinga Basin. Elsewhere, interval thickness ranges from 0.3-1 s two-way-time with no apparent trend; highlighting complex, current-related deposition with variable mechanisms.

\subsubsection{Seabed}

The seabed is a high-amplitude, positive polarity reflector, ranging from 0.1-5.5 s two-waytime throughout the study area (Figure 2.14A). High-resolution $(25 \mathrm{~m})$ swath data (Bache et al., 2014c) reveal several subdued bathymetric features not visible the seismically derived bathymetry (Figure 2.14B). Along southeast Reinga Ridge, the seabed has erosional morphology, flat benches and canyons potentially carved out by strong bottom currents of the Tasman Front (Chiswell et al., 2015). These south-southeast flowing currents create northwest-southeast trending sediment waves with $\sim 200 \mathrm{~m}$ wavelength and $\sim 5 \mathrm{~km}$ axial length (Figure 2.14C). 


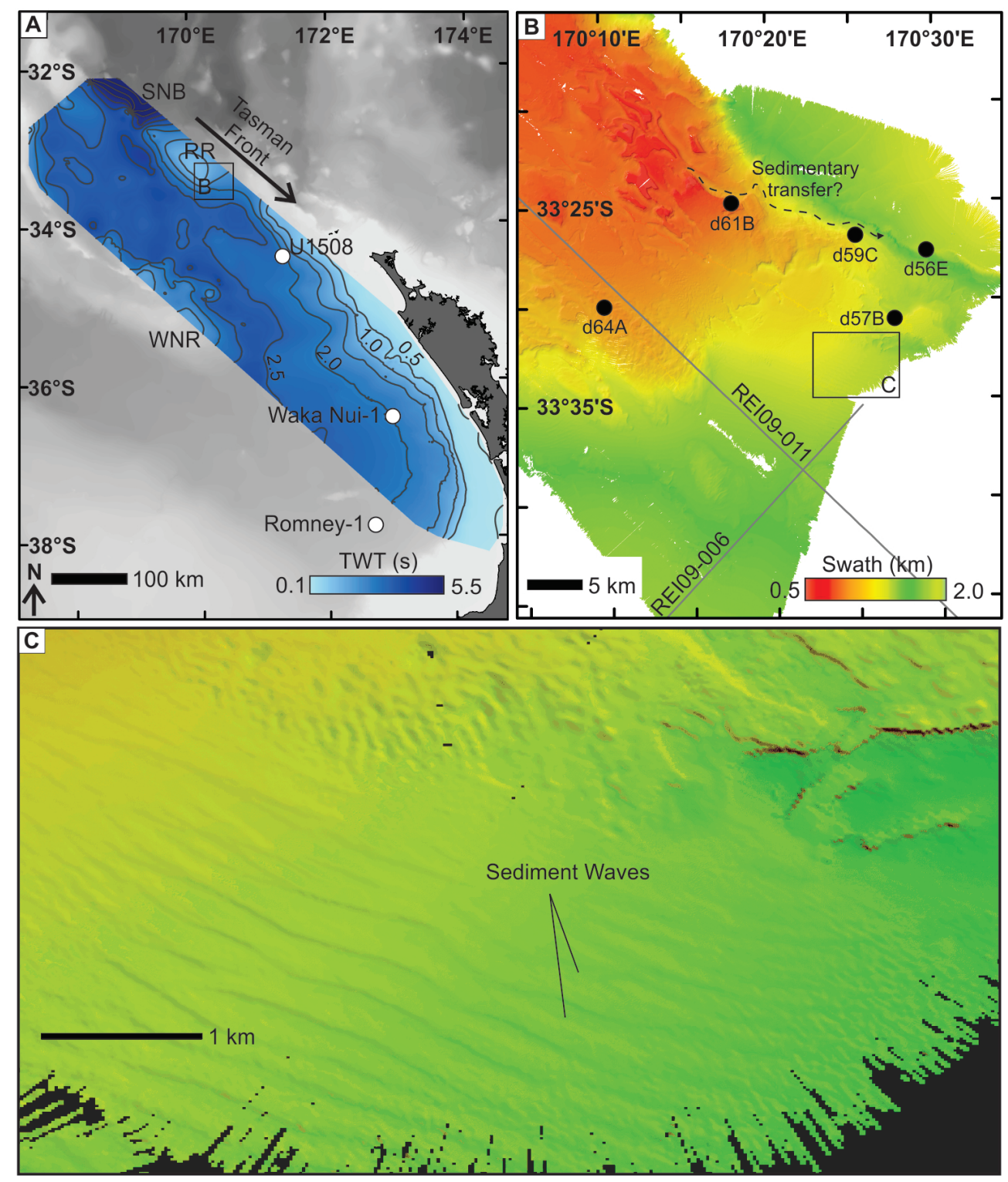

Figure 2.14: (A) Seismically-derived bathymetry for northwest New Zealand. Physiographic features are: RR, Reinga Ridge; SNB, South Norfolk Basin; WNR, West Norfolk Ridge. Tasman Front flow direction is inferred from Chiswell et al. (2015). Contour interval is 0.5 s. (B) Swath bathymetry (Bache et al. 2014c) over the eastern flank of Reinga Ridge (box in A); black circles indicate TAN1312 dredge sample locations. (C) Enlargement of area (box in B) showing large $\sim 200 \mathrm{~m}$ wavelength, $\sim 5 \mathrm{~km}$ axial length sediment waves in $\sim 1500 \mathrm{~m}$ water depth formed by strong deep-current flows of the Tasman Front. 


\subsubsection{Faulting}

Types of faulting observed across Reinga and Northland basins are fourfold: compaction, detachment, normal and reverse faulting.

Pervasive small-offset polygonal faults are observed above horizon UB5 within both basins. Polygonal faults are particularly common in northern Zealandia (Stratford et al., 2018), and Zealandia-wide (Morley et al., 2017) chalk layers. The highest density of polygonal faults in Reinga Basin occur within undulating reflectors of seismic units U7 (Figures 2.7, 2.11) and U8 (Figure 2.8). Similarly, the highest density of polygonal faults in Northland Basin occur at the chaotic, downlapping base of U7 (Figure 2.13). This deformation probably arose from compaction and fluid expulsion during diagenesis (Stratford et al., 2018).

Detachment faults are observed at the base of allochthonous wedges along South Maria Ridge and adjacent to Northland, and are mapped at the base of predominantly chaotic seismic facies with minor sedimentary features. For more discussion about allochthons - see Section 2.3.12.

Northwest to southeast trending normal faults are observed in southern Reinga Basin and Northland Basin (Bache et al. 2012a,b; Figure 2.15). Faults affect the deepest discernible sedimentary reflections, all of which pre-date the UB3 horizon (i.e. are older than the mapped sedimentary succession). Shortening and inversion of pre-existing normal faults is accommodated at Reinga Basin margins. Normal faults are also observed through the axis of West Norfolk and Wanganella ridges (Figure 2.15).

Reverse faulting is widespread across Reinga Basin and is concentrated in the northwest (Bache et al. 2012a,b; Figure 2.15). Low-angle thrust faults and northeast verging folds are observed beneath southern Norfolk Ridge and affect the deeper sedimentary succession (Sutherland et al., 2017). Major reverse faults affecting the shallower sedimentary succession (U4-U5) are located at Reinga Basin margins: West Norfolk Ridge (Figure 2.7), South Maria Ridge (Figure 2.8) and Reinga Ridge (Figure 2.9). The degree to which U4-U5 are folded varies across Reinga Basin, indicating a spatial variation in timing and magnitude of deformation within the basin.

Identifying faults is intuitive (e.g. clear vertical reflector offset) but for low angle faults it is less obvious. Thrust faults are interpreted where foot-wall and hanging-wall cut-offs are clearly seen on vertically exaggerated seismic sections (e.g. Figure 2.9) and where bright reflectors that are more continuous truncate or dislocate shorter folded reflectors (e.g. Figure 2.8). Detachment faults are interpreted where there is clear separation between an allochthonous body with chaotic and sedimentary reflectors over incoherent basement rock and under onlapping strata (e.g. Figure 2.16). 


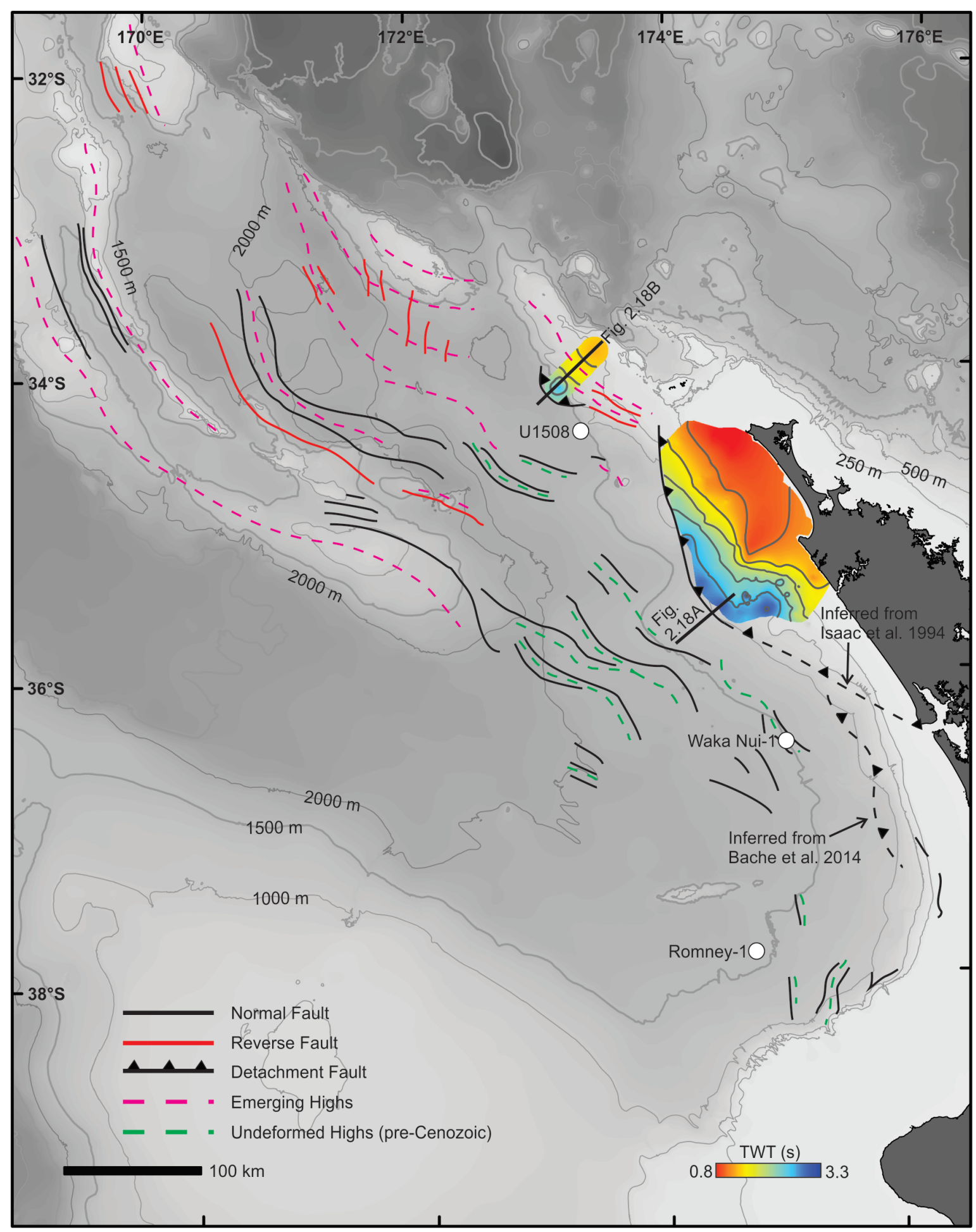

Figure 2.15: Structural map of Reinga and Northland basins showing the type and distribution of mapped faults (after Bache et al. 2012a,b), and two-way-time structure grids of South Maria (north) and Northland (south) allochthons. Contour interval is $0.5 \mathrm{~s}$. Reverse faults and emerging highs (folds) are widespread in northwest Reinga Basin. Normal faults and undeformed pre-Cenozoic (basement) highs are widespread to the south. Black lines through allochthon grids indicate approximate figure locations. Black dashed lines indicate detachment faults affecting the Northland Allochthon (after Isaac et al. 1994) and the Mesozoic Allochthon (after Bache et al. 2014a). 


\subsubsection{Allochthons}

Previous interpretations characterise the Northland Allochthon as a southwest verging wedge (Rait, 2000), identified on seismic reflection data by the presence of a predominantly chaotic seismic facies with some minor sedimentary features (Isaac et al., 1994; Herzer, 1995). The top surface ranges from 0.8-2.7 s two-way-time (Figure 2.15), and lies within U6 in southern Reinga Basin and northern Northland Basin, coinciding with UB5 at its base (Figure 2.16A). U6 reflectors are continuous, high- to moderate-amplitude, and have clear onlap termination; U6a and U6b reflectors are blocky, tilted, moderate-amplitude, and have clear downlap termination. The degree to which U6a and U6b downlap, and younger units are tilted, increases southward with proximity to Northland Peninsula.

A wedge of similar seismic character is observed north along southwest South Maria Ridge (Figure 2.16B). The top surface of the allochthonous wedge is delineated by a smooth highamplitude surface that observed across the mapped portion of South Maria Ridge (Section 2.3.14), and overlain by flat-lying strata. Contrary to observations south, U6 strata downlap UB5, and U7 strata onlap UB6. U8 and U9 strata are comparatively less tilted. Unfortunately, this feature is only observed on one seismic reflection line (REI09-010), limiting the mapped extent.

Bache et al. (2014a) identified the presence of an older, deeper Mesozoic allochthon in central Northland Basin, that can be distinguished from Cenozoic allochthons by its stratigraphic position and seismic character (see Section 3.4). 

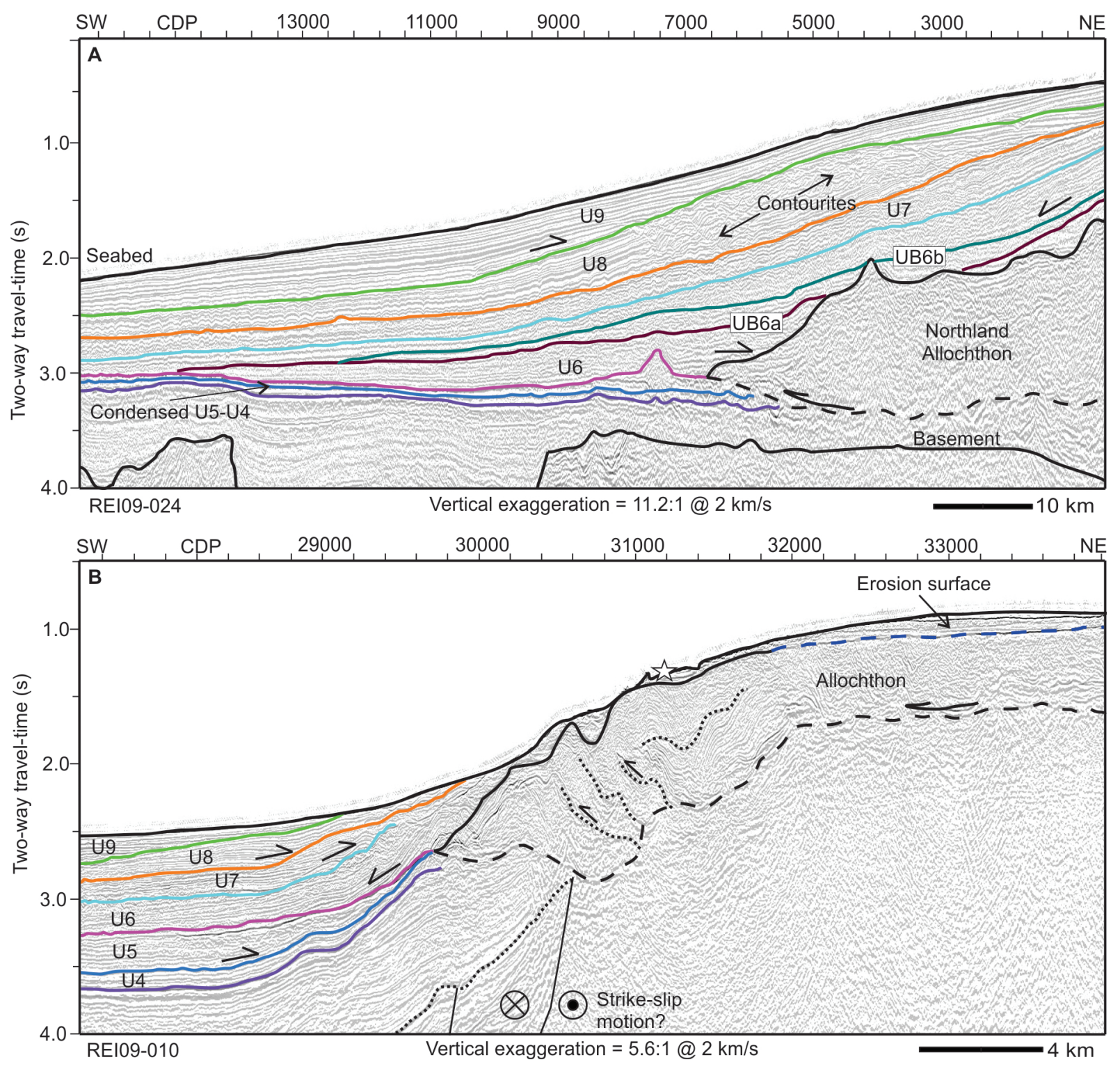

Figure 2.16: (A) Interpreted part of seismic line REI09-024 showing stratigraphic relationships to the Northland Allochthon in southern Reinga Basin. Emplacement occurs during U6 as UB5 is inferred to be coeval with the base of Northland Allochthon. Overlying U6a and U6b strata downlap, suggesting they are sourced from the allochthon. Emplacement causes the regional tilting, subsequently affecting the dip of younger strata near Northland. (B) Interpreted part of seismic line REI09-010 showing stratigraphic relationships to an allochthon along South Maria Ridge in central Reinga Basin. Contrary to (A), U6 strata downlap, and U7 strata onlap their respective basal unconformities. Dredged sediment from the seabed constrains the timing of emplacement and subsequent subsidence (white star - see Section 3.2.7). 


\subsubsection{Volcanic edifices}

Mapped volcanic edifices in this study range from 0.2-3.6 s two-way-time across Reinga and Northland basins, where they occur sporadically and typically deeper in the former, and clustered and shallower in the latter (Figure 2.17). The top of volcanic edifices are characterised by moderate- to high-amplitude, positive polarity, discontinuous reflectors. Underlying reflectors are chaotic due to acoustic scattering associated with volcanic flows, breccias and intrusions (Herzer, 1995). Seismic units U6, U7, U8 and U9 are typically high-amplitude and terminate with onlap configuration against the identified body (Figure 2.17A). In some cases, U6 reflectors in Northland and Reinga Basin downlap adjacent to these volcanoes, and become conformable with increasing distance away.

Identification of 50 volcanic edifices, and five massfis, on seismic reflections profiles in Northland Basin was initially made by Herzer (1995) using the GECO spec survey (1982), prior to the collection of CNL data (1995). Herzer (1995) outlines the evidence for volcanic edifices, where each body comprises a flat-topped cone with steeply dipping sides, an apron with gently dipping lower flanks and a ring plain which is an almost flat region beyond the apron (Figure 2.17A). The top and flanks of larger volcanics in Northland were subject to sub-aerial and wave erosion, contributing to identified epiclastic sequences. The apron is characterised by high-amplitude and sub-parallel reflectors that slope away from the main body, becoming parallel to over and underlying reflectors. The ring-plain is characterised by a high-amplitude reflector with basal onlap, that laterally grades into the sloping apron (Figure 2.17A).

Volcanoes are typically represented by cone-shaped features (Figure 2.17B), with larger features observed near West Norfolk Ridge in Reinga Basin (Bache et al., 2014c). Reflectors adjacent to shallower, smaller volcanoes exhibit current scouring (Figure 2.10B), highlighting the effect of paleotopography on deposition after emplacement. Most volcanic edifices across the mapped area downlap and correspond to horizon UB5, however, timing may vary between basins if the horizon is diachronous. 


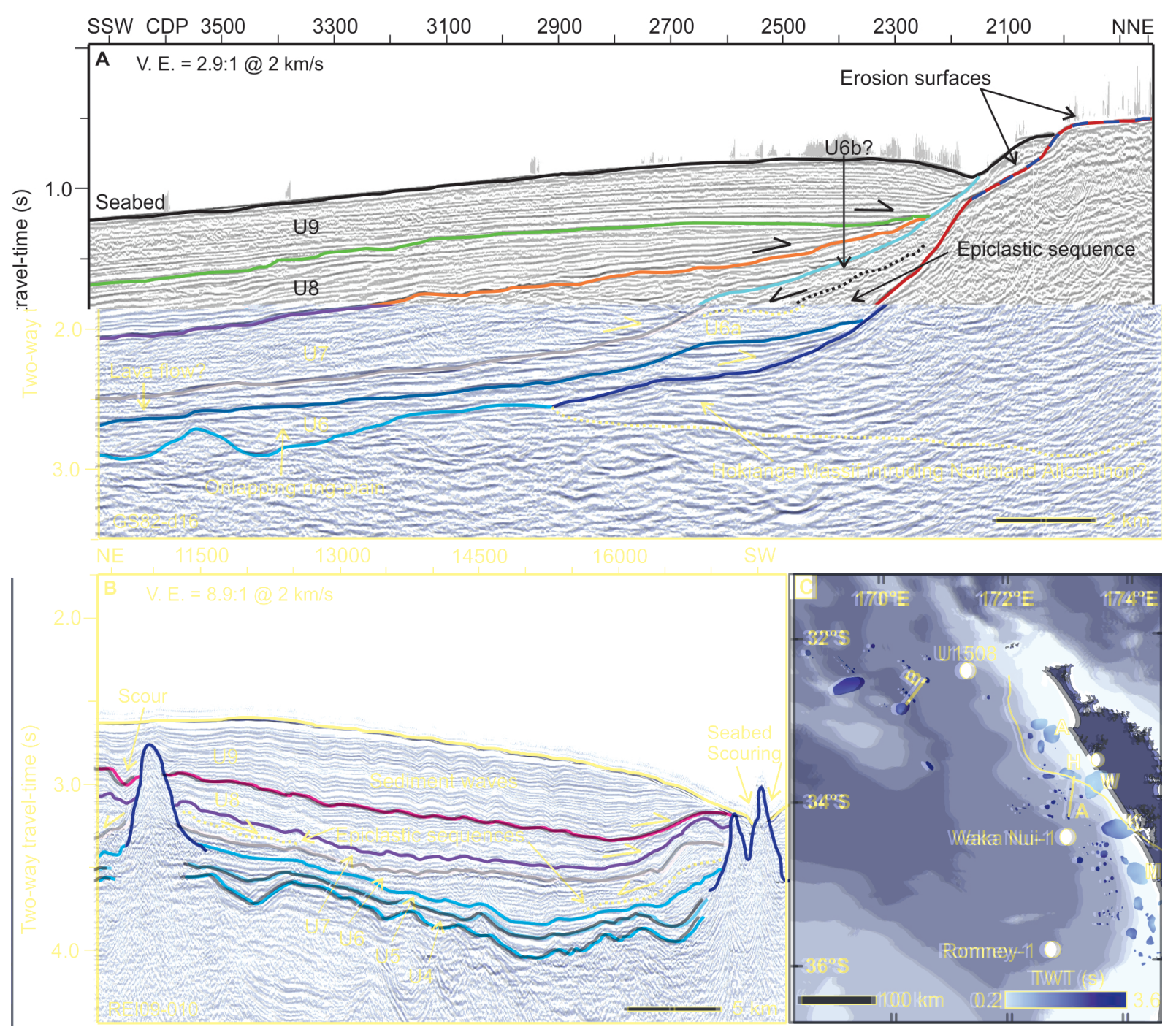

Figure 2.17: (A) Part of seismic reflection line GS82-d16 showing stratigraphic relationships to the Hokianga massif in Northland Basin. Apron, epiclastic and ring-plain features are identified, and are characteristic of larger volcanoes throughout the basin. The volcanic edifice are inferred to intrude the Northland Allochthon at this location. (B) Part of seismic reflection line REI09010 showing stratigraphic relationships to volcanic edifices in Reinga Basin. Seismic characteristics are similar to Northland Basin, but are smaller scale. Current scouring is prominent adjacent to buried volcanoes, and those exposed at the seabed. (C) Two-way-time structure map showing the distribution of volcanic edifices across Reinga and Northland basins. Mapped volcanoes are related to older stratigraphy and more sparse in Reinga Basin, compared to clustered volcanoes that relate to younger stratigraphy in Northland Basin. Grids are cropped mapped edifices of Herzer (1995) and Hayward et al. (2001). 


\subsubsection{Wave ravinement surfaces}

Erosion surfaces are manifest by flat, high-amplitude, positive polarity reflectors that range from 0.3-3.3 s two-way-time across basin ridges (Figure 2.18). They are distinguishable from major seismic-stratigraphic boundaries by a smooth and planar geometry over relatively small horizontal distances, that typically truncate underlying, folded strata (Bache et al., 2014b). Overlying strata are undeformed (Figure 2.18A) and/or terminate against the erosion surface with onlap configuration (Figure $2.18 \mathrm{~B}, \mathrm{C}$ ). There are a few sources of possible erosion to form these surfaces and are discussed below.

Wave ravinement surfaces are formed through the erosion of land by marine transgressions (i.e. when base-level change out paces sediment supply), therefore represent paleo-shelf and seabed elevations that can be used to estimate relative paleo-sea level and shoreline position at the time of formation (Bache et al., 2014b). The water depth in which wave ravinement occurs is typically of the order 10-20 m (Demarest and Kraft, 1987), but in the Tasman Sea this would be $<30 \mathrm{~m}$ based on wave base and the size of the ocean (L. Strachan, personal communication).

Regional deep-water currents have been inferred to be strong in the Tasman Sea, leading to little recovered middle Eocene to middle Oligocene aged sediment on previous drilling voyages (Sutherland et al., 2018). It is well documented that strong regional currents erode and winnow the seabed across parts of New Zealand. Cook Strait is eroded by tidally-driven flows up to 350 m water depth (Carter et al., 1991; Carter, 1992; Mountjoy et al., 2009), and Canterbury Shelf is eroded by thermohaline and wind-driven flows up to $200 \mathrm{~m}$ (Carter and Herzer, 1979; Carter et al., 2004).

The preferred erosional mechanism that will be used herein is wave ravinement (Bache et al., 2014b). Rationale for this is twofold: bounding ridges comprise material that is unlikely eroded by bottom currents (e.g. Section 1.2) and it is doubtful bottom currents would produce flat surfaces with regional consistency.

Wave ravinement surfaces coincide with different seismic horizons across Reinga Basin. Along northern West Norfolk and Wanganella Ridges it is difficult to tie the erosion surface to seismic-stratigraphy (Figure 2.18A). Along southern West Norfolk Ridge wave ravinement is tied to U4 (Figure 2.18B). Along South Maria Ridge wave ravinement is tied to U6 (Figure 2.18C). Farther south wave ravinement is similarly tied to U6, but U6 deposits overlie the surface, suggesting it is older than the South Maria surface (Figure 2.11). Wave ravinement surfaces also truncate tops and flanks of volcanic edifices (Figure 2.17), where overlying reflectors exhibit onlap termination (Herzer, 1995). 

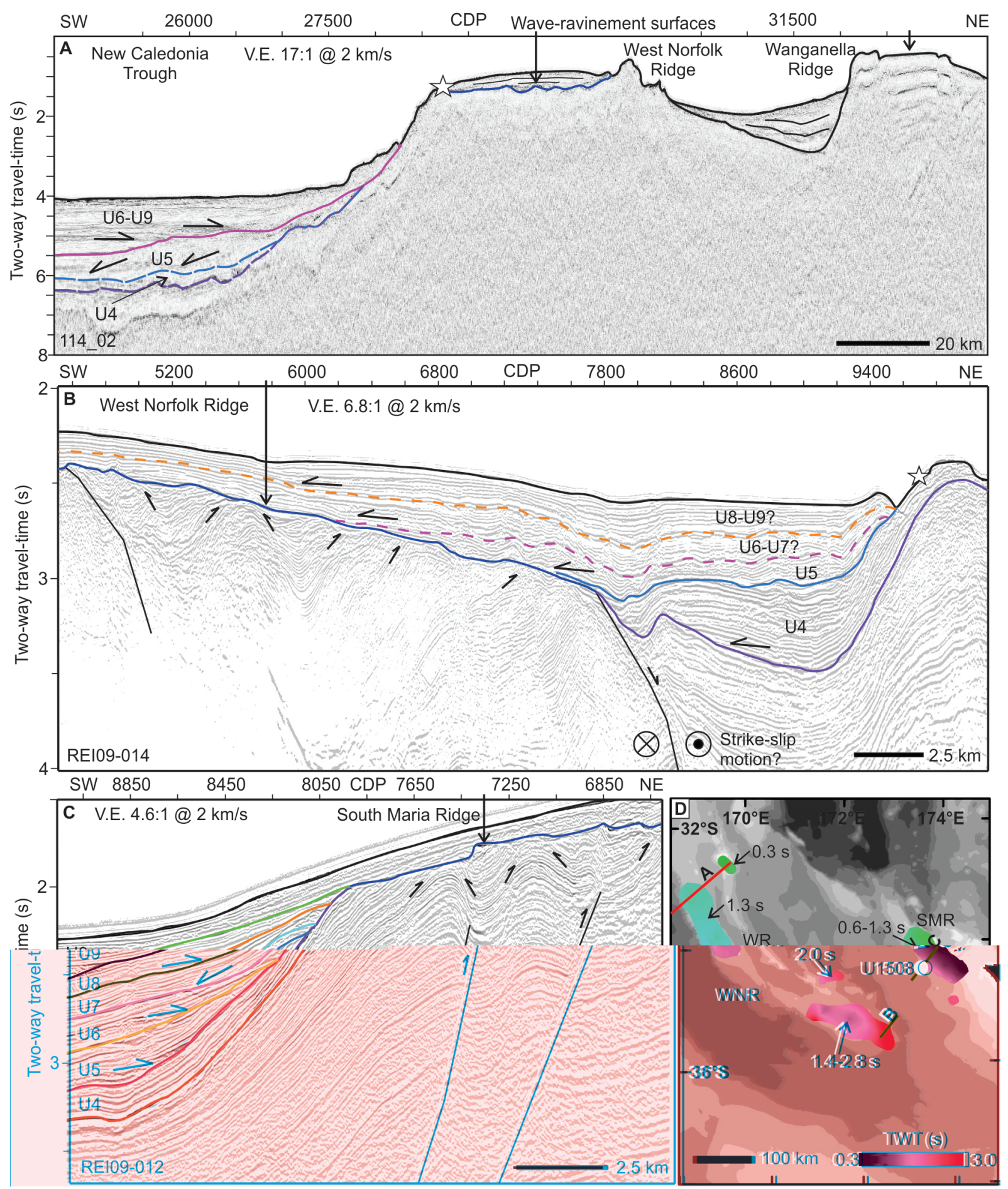

Figure 2.18: Interpreted seismic reflection lines showing seismic-stratigraphic relationships to wave ravinement surfaces across Reinga Basin. (A) Part of seismic reflection line 114-02 showing truncation of West Norfolk and Wanganella Ridge. (B) Part of seismic reflection line REI09-014 showing truncation of folded strata and onlap of U5 and younger strata along southern West Norfolk Rigde. (C) Part of seismic reflection line REI09-012 showing truncation of folded strata and onlap of U9 strata along South Maria Rigde (D) Two-way-time structure grid showing the distribution of wave ravinement surfaces in Reinga Basin. Red lines indicate approximate figure locations. SMR, South Maria Ridge; WR, Wanganella Ridge; WNR, West Norfolk Ridge. 


\subsection{Synthesis of seismic stratigraphy}

Eight seismic-stratigraphic units have been mapped using seismic reflector terminations and seismic reflection configurations (U4-U9; Figure 2.19), formed during different deformational events in Reinga and Northland basins. All seismic-stratigraphic units are reliably traced throughout the study area.

Seismic Unit 4 (U4) strata onlap its basal unconformity (UB3) near deformed ridges in western Reinga Basin (Figure 2.7). It is strongly folded and parallel in eastern Reinga Basin, and is relatively undeformed in Northland Basin where no angular discordance is observed. Seismic facies contain high-amplitude and parallel reflectors. U4 is predominantly thin (< $0.2 \mathrm{~s}$ two-way-time), but is thicker ( $>0.5 \mathrm{~s}$ two-way-time) in central Reinga Basin, and along Wanganella Ridge (2 s two-way-time). U4 comprises strata that record three types of deformation: (1) a folded and faulted sequence pre-dating deformation, (2) an onalpping syn-tectonic sequence, and (3) undeformed strata far-field to deformation.

Seismic Unit 5 (U5) strata are folded and onlap the basal unconformity (UB4) in central (Figure 2.7) and eastern (Figure 2.8) Reinga Basin, separating less deformed sub-horizontal reflectors from underlying folded U4. Seismic facies contain thin ( $<0.2 \mathrm{~s}$ two-way-time), parallel reflectors in most places, but are locally thick ( $>5 \mathrm{~s}$ two-way-time) in central Reinga Basin where it fills a syncline. U5 is variable across the study area. It comprises a divergent facies beneath Wanganella Ridge, and no angular discordance is observed in Northland Basin. Therefore, U5 comprises strata that record different types of deformation: (1) syn-tectonic growth strata, and (2) undeformed strata far-field to deformation.

Seismic Unit 6 (U6) strata onlap its basal unconformity (UB5) in both Reinga (Figure 2.8) and Northland (Figure 2.13) basins. In northwest Reinga Basin, U6 is confined to synclines, where sub-parallel reflectors onlap anticline margins. It is strongly unconformable against Wanganella Ridge, but is continuous in southeast Reinga and Northland basins and has volcanic edifices and progradational wedges at its base. Strata downlap in close proximity to South Maria Allochthon along South Maria Ridge (Figure 2.16). Where U6 is thin $(<0.2 \mathrm{~s}$ two-way-time), seismic facies contain sub-parallel reflections, but where it is thickest $(\sim 0.6 \mathrm{~s}$ two-way-time), seismic facies contain undulating reflectors.

Seismic Unit 7 (U7) strata downlap or onlap its basal unconformity (UB6). In Reinga Basin, U7 downlaps locally near Site U1508, but onlaps everywhere else. The degree at which reflectors downlap increases near Northland Peninsula. U7 strata are continuous, and are distinguished from underlying U6 strata by a higher-amplitude seismic package. Similar to U6, U7 strata terminate with an onlap configuration against pervasive volcanic edifices. Where the unit is thin $(<0.2 \mathrm{~s}$ two-way-time) seismic facies contain sub-parallel reflections, 
but where it is thickest in sub-regions (up to $0.6 \mathrm{~s}$ two-way-time near Northland), seismic facies contain undulating reflectors that are affected by polygonal faults.

Seismic Units 8 (U8) and 9 (U9) onlap their respective basal unconformities (UB7 and UB8) in Reinga and Northland basins. Both units drape onto older units, and are influenced by complex current-related deposition. U8 is mostly thin (<0.2 s two-way-time), but is up to 0.4 - 0.6 s two-way-time near South Maria Ridge and Northland Peninsula. U8 seismic facies contain sub-parallel reflectors in distal parts on Reinga and Northland basins; and hummocky to mounded reflectors closer to the present-day shelf. Oblique seismic facies are observed where U9 truncates U8 along basin margins and the shelf. U9 ranges in thickness from 0.3 - 1 s two-way-time acorss the mapped region with no apparent trend. This probably arose from variable deposition due to currents similar to present-day (e.g. Nelson et al. 1982). Seismic facies predominantly contain parallel reflections, but also include sigmoidal facies close to the shelf.

Three units constrain the timing of tectonic events: faulted and folded strata older than the event, syn-tectonic growth strata recording progressive deformation during the event, and undeformed strata younger than the event. U4-U5 contains folded, faulted and onlapping reflectors that indicate progressive deformation. The stratigraphic ages of deformed units appear older in northwestern Reinga Basin. U6-U7 contain fanning reflectors that onlap, recording folding, uplift-subsidence, erosion and volcanic input near the basin margins (Sutherland et al., 2019a). These four units are interpreted as first-order tectonic-related sequences. U8-U9 sequences drape overlying older, folded strata, and are second-order sequences related to sea-level and sediment supply. For interpretation and reasoning of U3 to U1 see Bache et al. (2012a,b). 


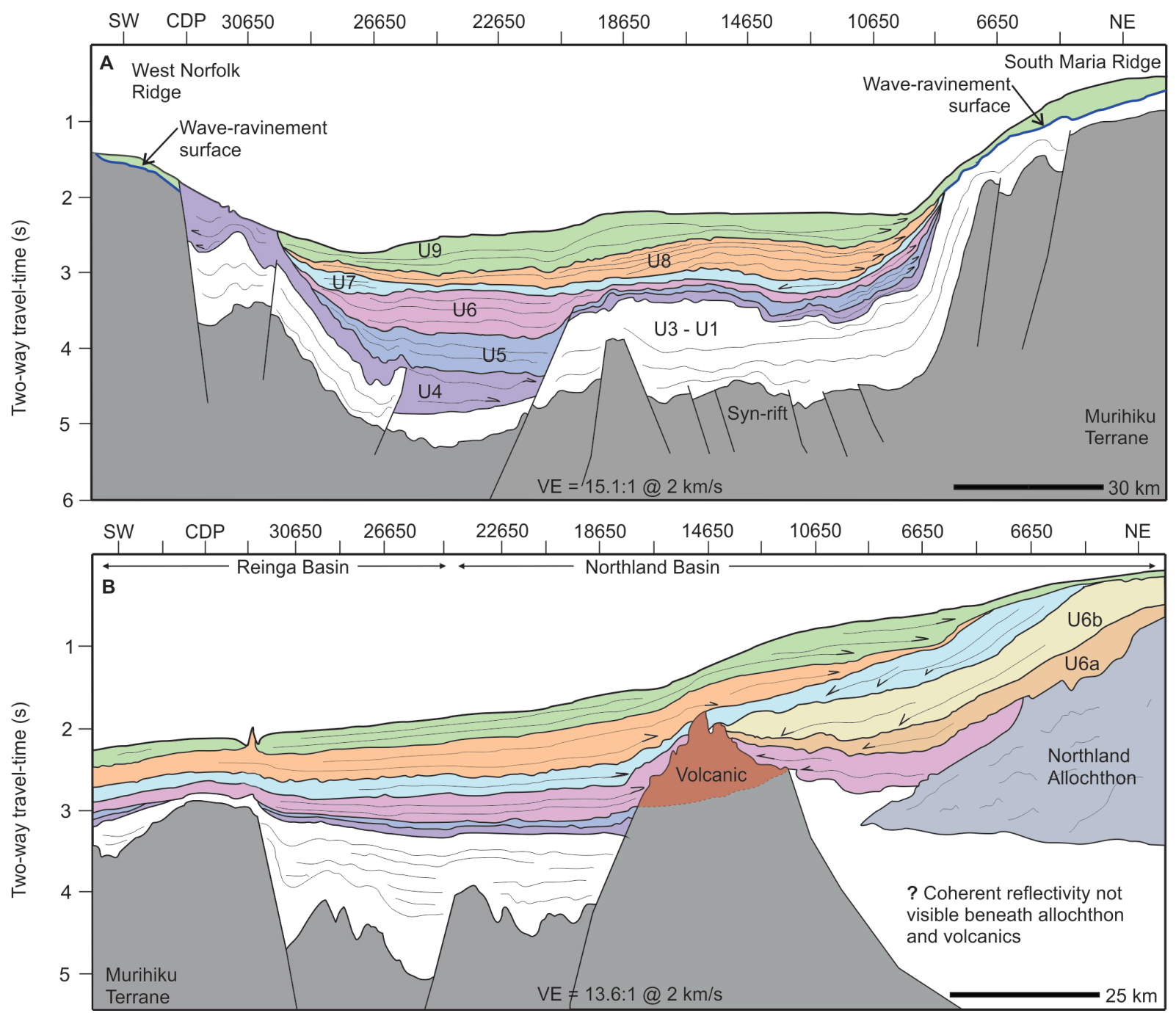

Figure 2.19: Line drawings across Reinga and Northland basins summarising seismic-stratigraphic units of inferred Eocene to Recent age and stratigraphic variability between basins. (A) The centre of Reinga Basin is characterised by a thick section of parallel flat-lying strata. Near South Maria Ridge, the mapped sequence comprises folded and fanning strata. U4 strata are affected by normal and reverse faults, and onlap West Norfolk Ridge. U4 is folded and onlapped by strata of inferred Eocene to Pleistocene (U5-U9) age against South Maria Ridge. Conversely, these units pinch-out against U4 along West Norfolk Ridge. Wave ravinement surfaces are mapped on basin-bounding ridges. These surfaces are deeper on West Norfolk Ridge compared to South Maria Ridge. (B) U4 and U5 strata are comparatively thinner and conformable farther south towards Northland Basin. Emplacement of volcanics, Northland Allochthon and sub-units U6a and U6b occurs during deposition of U6. Line locations are shown by solid red lines in Figure 2.1. 


\subsection{Depth Conversion}

Depth conversion of seismic-stratigraphic horizons and intervals was undertaken using data from boreholes. Boreholes are sparse offshore northwestern New Zealand, however the adjacent Taranaki Basin has been extensively explored for hydrocarbons and is the closest high-density dataset available. Check shot data from 13 wells (Stratford et al., 2018) have been integrated with velocity data from Site U1508 (Sutherland et al., 2019a) and Waka Nui-1 (Stagpoole, 2011) to calculate two-way-time with depth values (Figure 2.20). Depth structure and isopach grids were generated using the grid calculator tool in SeisWare, with minimum curvature interpolation and a mask applied $15 \mathrm{~km}$ from data. Depth to seafloor was calculated assuming a velocity of $1500 \mathrm{~ms}^{-1}$. Depth structure grids were calculated by subtracting from the two-way-time of the seabed from the desired horizon and applying the numerical solution (Figure 2.20A). In turn, isopach maps were calculated by subtracting the top binding horizon from the bottom binding horizon.

Grids generated using this method come with inherent assumptions and uncertainty. Sediment isopachs are assumed to represent a homogeneous facies, with negligible effects of different sediment sources (i.e. terrigenous versus marine). Accuracy may be compromised in areas that are highly tectonised, along basin flanks, and with variable lithification. The Taranaki solution is less well constrained $<300 \mathrm{~m}$ bsf and over-estimates shallow velocities (Stratford et al., 2018), therefore these data were removed. Variability and estimates of uncertainty in check shot data are determined from the residual of the predicted two-waytime with depth solution (Figure 2.20B). The standard deviation for all data points is 111 $\mathrm{m}$, but for data $<2000 \mathrm{~m}$ bsf, the standard deviation is $65 \mathrm{~m}$ (see Appendix B.2 for values).

Depth converting mapped horizons provides an estimate of the total amount of sediment within each seismic unit deposited during tectonic deformation events. Results reveal a maximum thickness of inferred Eocene to Recent sediment of $3750 \mathrm{~m}$ in the centre of Reinga Basin (Figure 2.21). Individual seismic unit isopachs show a relatively consistent thickness of $\leq 200 \mathrm{~m}$, with variations reflecting time-transgressive deposition in Reinga Basin (Figure 2.22). U4 is thickest along western Reinga Basin, up to $3000 \mathrm{~m}$ near Wanganella Ridge and is $>200 \mathrm{~m}$ thick in localised areas near folds in northwest Reinga Basin. U5 is $\sim 600 \mathrm{~m}$ thick in northern Reinga Basin, and along with U6, is up to $1200 \mathrm{~m}$ thick in central Reinga Basin. U7-U9 are thickest $(\sim 600 \mathrm{~m})$ in localised areas, but are mostly variable. 


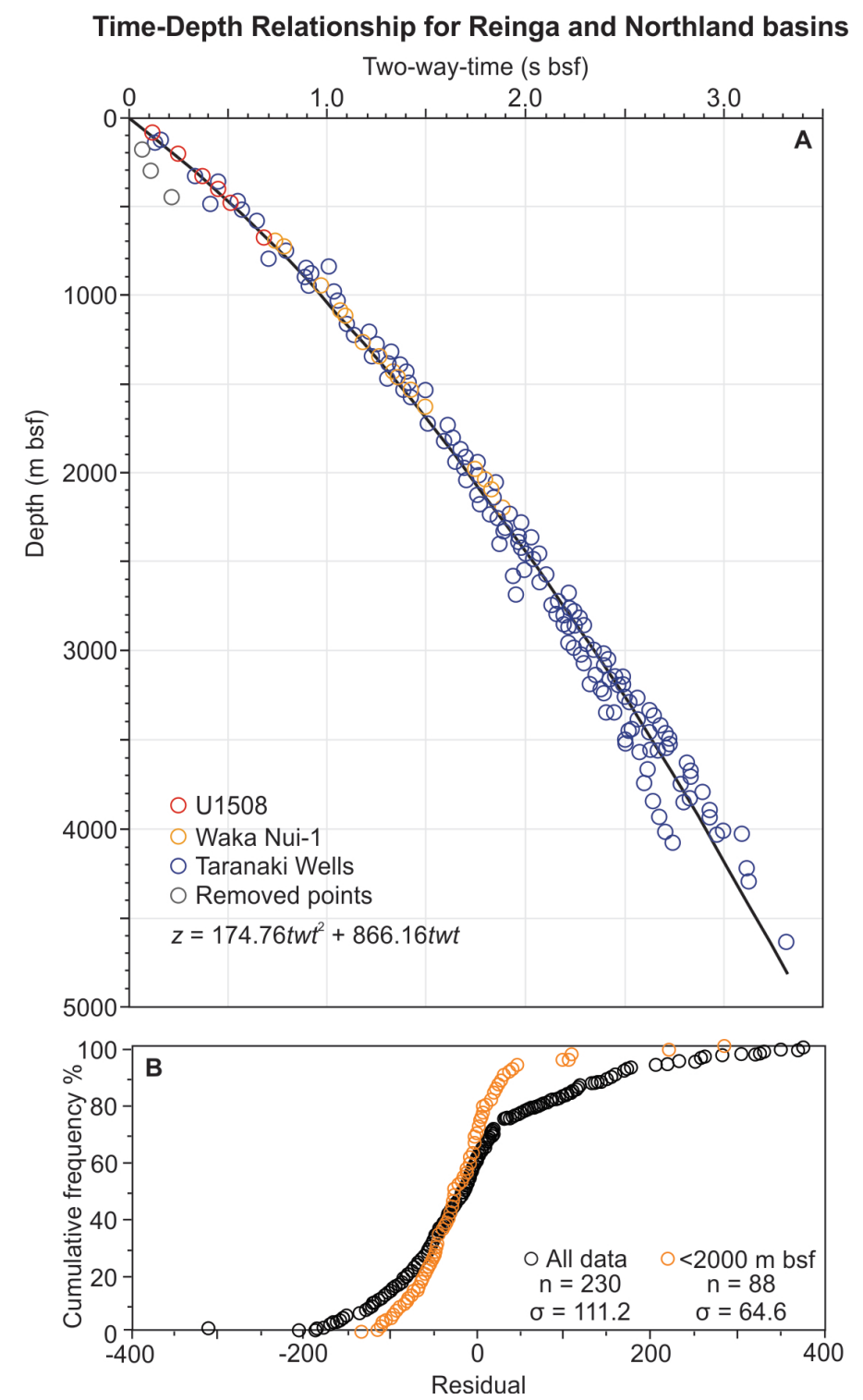

Figure 2.20: (A) Two-way-time with depth relationship derived for Reinga and Northland basins using data from Site U1508, Waka Nui-1 and select Taranaki Basin wells (see Appendix B.2 for points); modelled with a second order polynomial. (B) Residual plot showing variability and estimates of uncertainty in check shot data used for the two-way-time with depth relationship. Black circles are all check shot data. Orange circles are check shot data below $2000 \mathrm{~m}$ bsf and show a closer fit to the polynomial. 

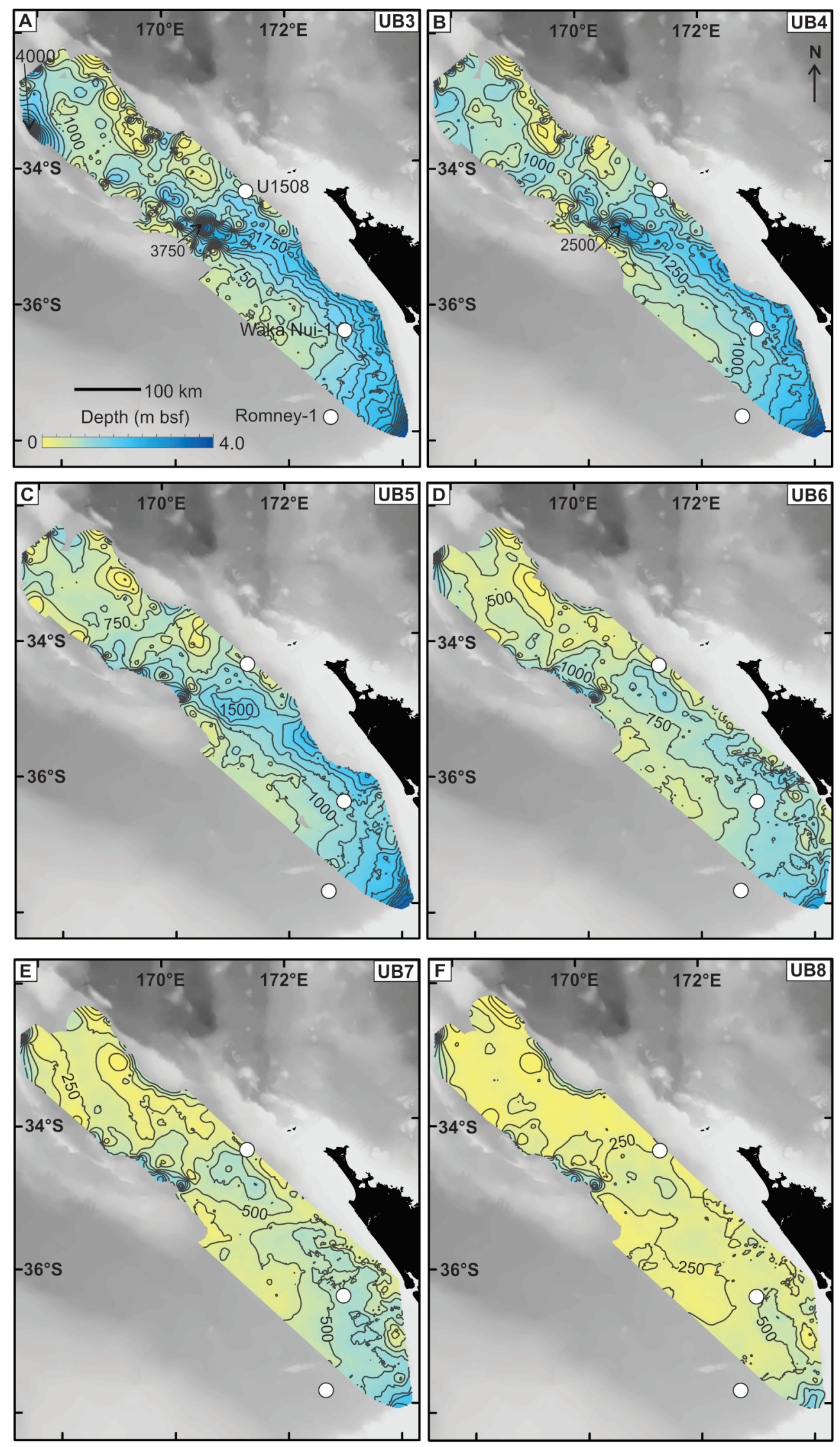

Figure 2.21: Depth structure grids of horizons UB3-UB8. Contour interval is $250 \mathrm{~m}$. 

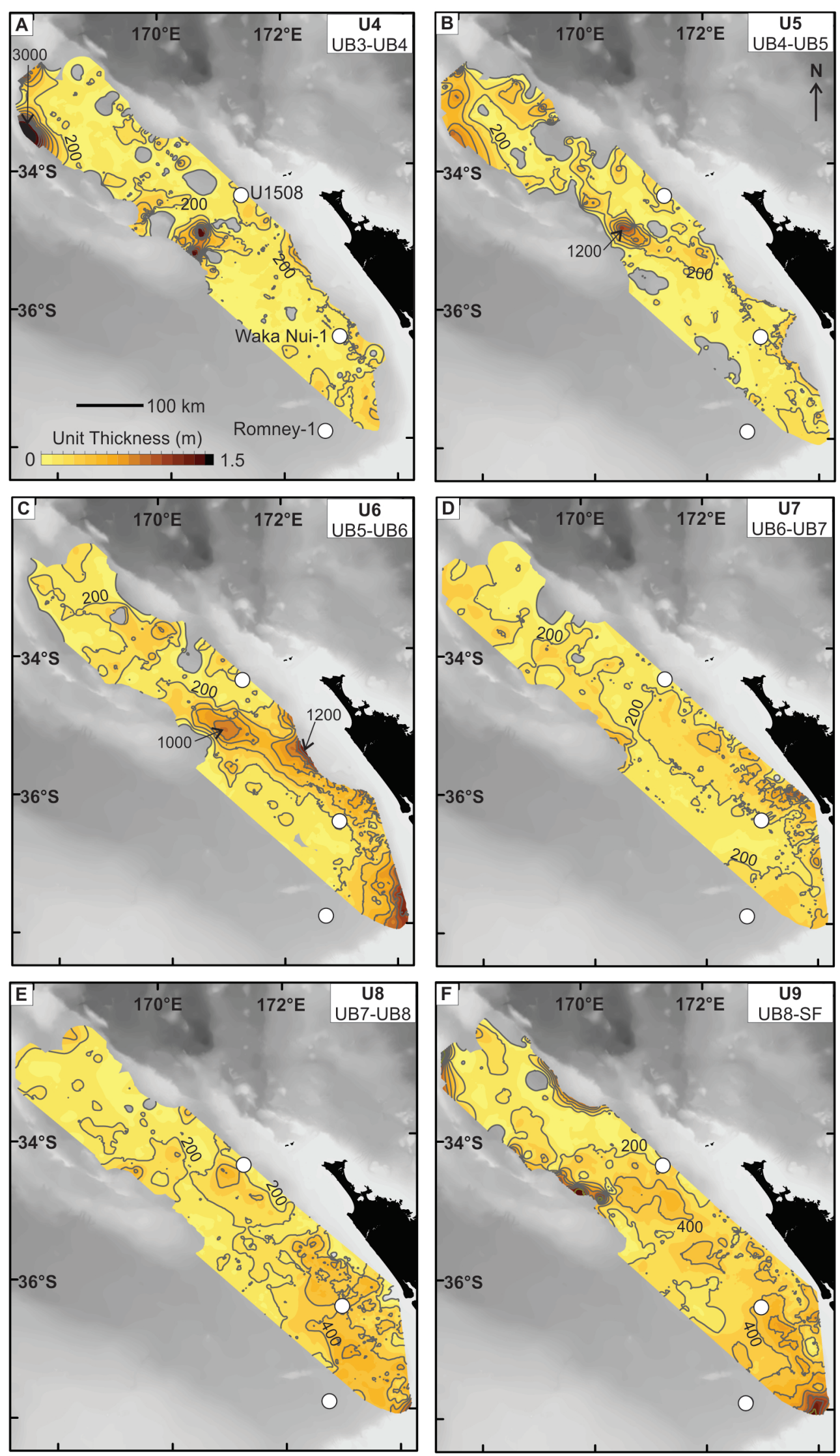

Figure 2.22: Depth isopach grids of units U4-U9. Contour interval is $200 \mathrm{~m}$. 


\section{Chapter 3}

\section{Rock Samples}

This chapter presents analysis of open-source data from TAN1312 dredge samples (Bache et al., 2014c; Browne et al., 2014), petroleum exploration well Waka Nui-1 (Milne and Quick, 1999) and IODP Site U1508 (Sutherland et al., 2019a). Post-voyage reports were reviewed to describe key lithostratigraphic units in their seismic-stratigraphic context in Reinga Basin.

\subsection{Age and paleoenvironment}

Fossil data were the primary basis for age and paleoenvironment evaluation of strata at sampled sites in Reinga and Northland basins (Strong et al., 1999; Browne et al., 2014; Sutherland et al., 2019a,b). Biostratigraphic age assignments are based on analyses of calcareous nannofossils, planktic and benthic foraminifers, radiolarians and palynomorphs, and are calibrated to the New Zealand timescale (Raine et al. 2015 - see Appendix A for timescale).

Paleoenvironment assignments are primarily based on benthic foraminifers at dredge sites and Waka Nui-1, but include ostracods for bathymetry, and palynomorphs for coastal proximity at Site U1508. Bathyal samples are not as sensitive to small changes in paleodepth compared to their neritic counterparts. Strong influence of substrate type, slope, sedimentation rate and water mass leads to imprecise calibration (Hayward, 1986). Consequently, conservative paleodepths are cited, following schemes of Hayward (1986) and van Morkhoven et al. (1986) using the following categories: neritic, $<200 \mathrm{~m}$ below sea level (bsl); bathyal, 200-2000 m bsl (upper bathyal, 200-600 m bsl; middle bathyal, 600-1000 m bsl; lower bathyal, 1000-2000 m bsl); abyssal, >2000 m bsl (Figure 3.1). 


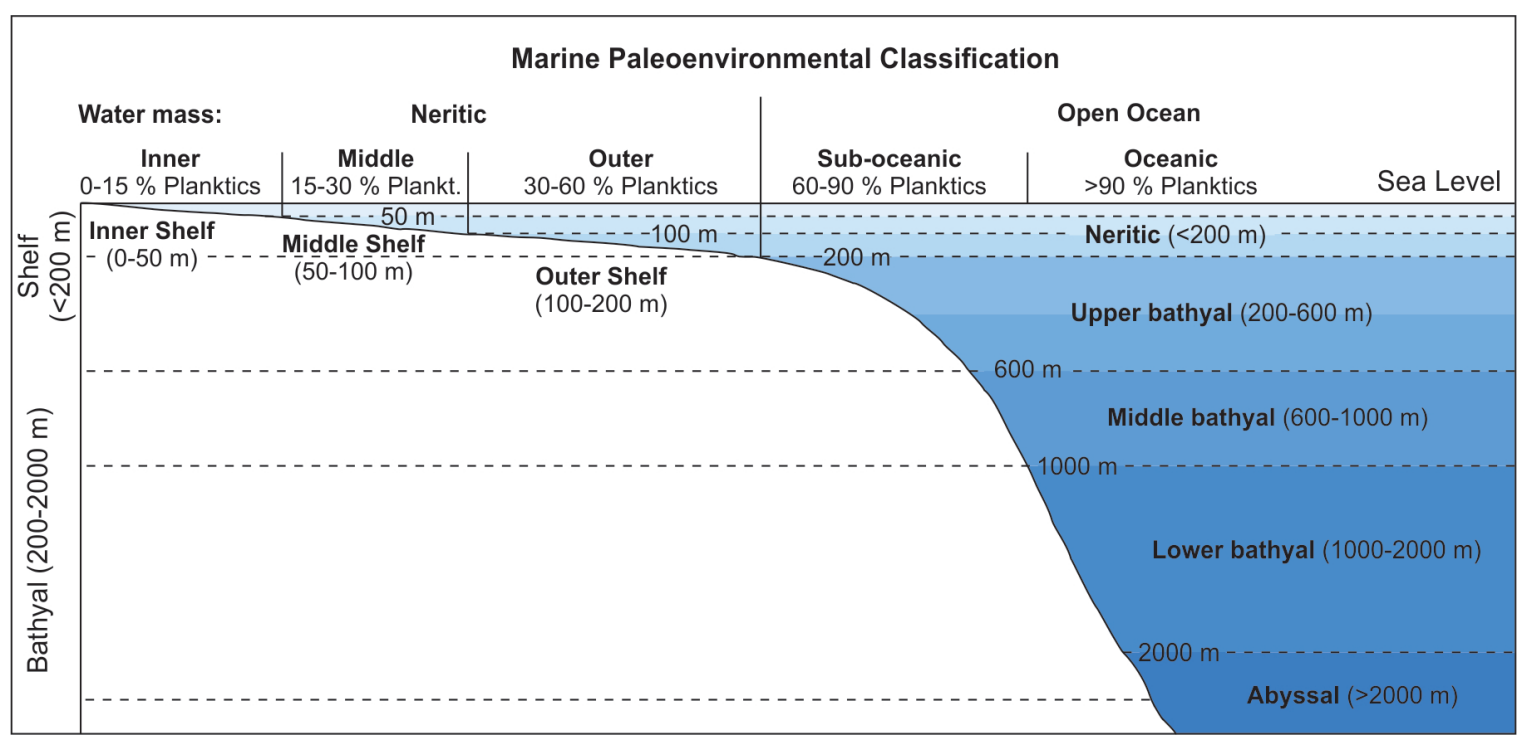

Figure 3.1: Marine paleoenvironmental classification scheme based on foraminiferal assemblages. Paleodepth zones follow Hayward (1986) and van Morkhoven et al. (1986). Figure is adopted and modified from Hayward (1999). 


\subsection{Dredge Samples}

Dredging rocks is a relatively cheap and practical alternative method of obtaining samples for analysis compared to drilling. This is especially useful in Reinga Basin, where inferred Eocene tectonic deformation has exposed older strata at the seabed (Bache et al., 2014c; Browne et al., 2016). Specific TAN1312 dredging sites were chosen on the basis of interpreted REI09 and 114 2D seismic reflection data prior to the voyage (Herzer et al., 1997; Bache et al., 2012a,b), and from multi-beam swath bathymetry data acquired during the cruise (Bache et al., 2014c). Primary targets were: dipping strata, unconformities, anticlines and acoustic basement (Browne et al., 2016).

A total of 37 sites were sampled, but only 7 sites and 8 samples are included in this study, based on proximal location to seismic data (Figure 3.2) and age (i.e. samples older than Eocene are excluded). Samples comprise micropaleontological and lithological data, and are summarised in Table 3.2. Older dredge samples (e.g. Herzer et al. 1997, 1999) were considered, but were of limited use. The exception is one sample located on the eastern side of Wanganella Ridge. The primary objective of assessing dredge samples was to build on descriptions of analytical work by Browne et al. (2016) and understand corresponding seismic-stratigraphic units. Samples are described in this section on a per site basis.

Carbonate samples recovered during the TAN1312 voyage were classified according to their major bioclastic constituents after the classification schemes of Dunham (1962) and Folk (1962) (Table 3.1). Coarse, bioclastic packstones are differentiated from coarse, bioclastic grainstones by a lower proportion of detrital grains and occurrence of common planktic foraminifera (Browne et al., 2014, 2016).

Table 3.1: Classification of carbonate sedimentary rocks identified in the TAN1312 voyage, based on major bioclastic constituents - following classification schemes of Dunham (1962) and Folk (1962).

Type

Mudstone

Wackestone

Fine, bioclastic packstone

Coarse, bioclastic packstone

Coarse, bioclastic grainstone

\section{Depositional texture}

Mud-supported, $<10 \%$ grains

Mud-supported, $>10 \%$ grains

Contains mud, grain-supported $(<\mathrm{mm}$-scale $)$

Lacks mud, large ( $>$ mm-scale) skeletal debris, forams

Lacks mud, large (>mm-scale) skeletal debris 


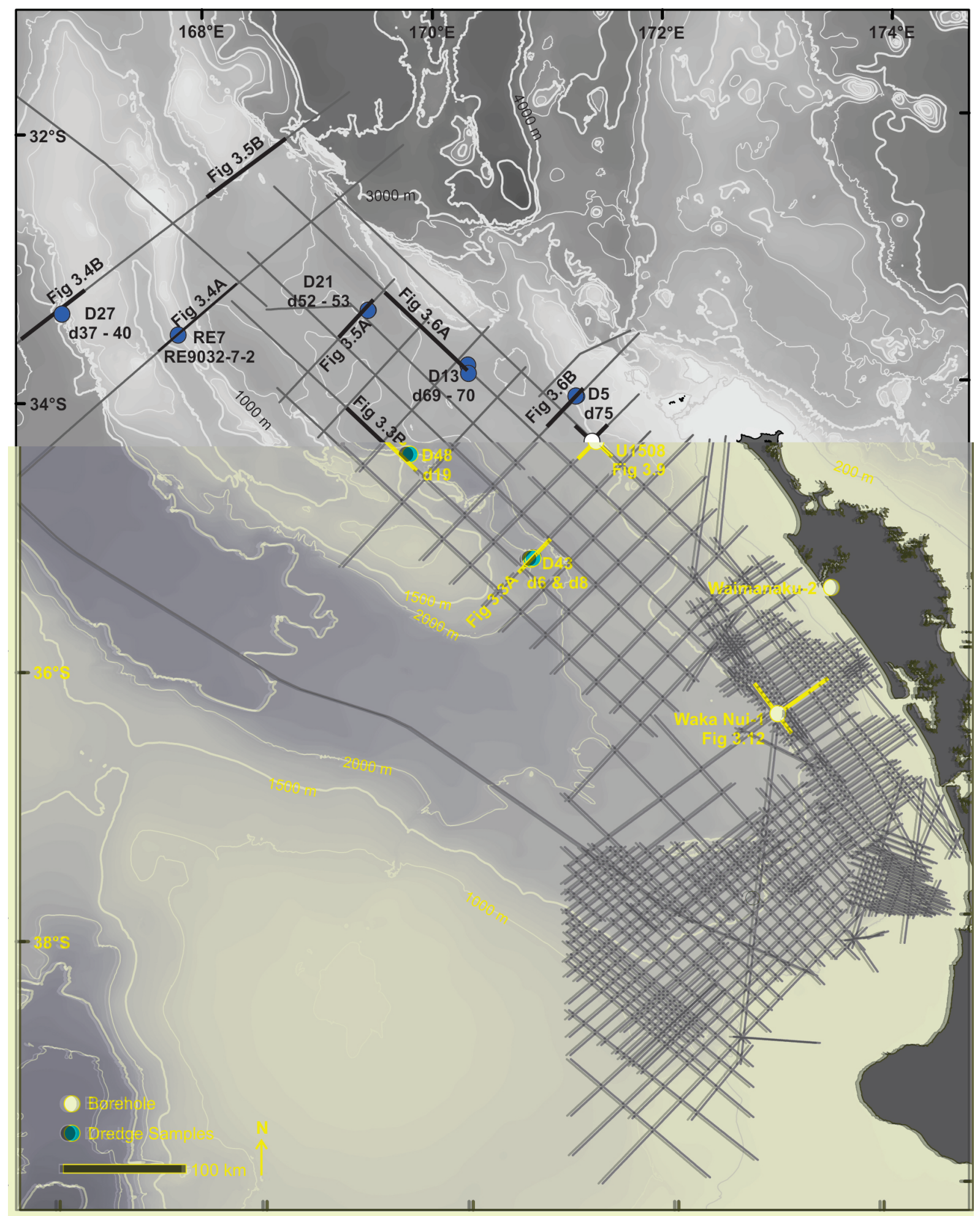

Figure 3.2: Bathymetric map (Mitchell et al., 2012) showing the location of dredge samples (blue circle) and borehole (white circle) data used in this study. Each TAN1312 dredge site (Bache et al., 2014c; Browne et al., 2016) has the prefix 'D' and a sample 'd', corresponding to age and lithology (see Table 3.2). One older RE9032 dredge sample (Herzer et al., 1997, 1999) is also included. Solid black lines indicate figure locations on 2D seismic data (grey lines) in this chapter. 
Table 3.2: Summary of paleontological and petrographic results for dredge samples used in this study (Browne et al., 2014, 2016). Abbreviated ages (e.g. 'Dh' for the New Zealand Heretaungan Stage, early Eocene) follow the New Zealand geological timescale after Raine et al. (2015). E, early; M, mid; L, late. Letters in brackets indicate the taxonomic group used for chronological analysis: F, foraminifera; R, radiolaria; ND, no date; NF, no flora/fauna. Lithology (lith.) abbreviations: Lst., limestone; Mst., mudstone. Depth (m) refers to the range sediments were recovered from the seabed. Latitude and longitude are given in decimal degrees (WGS84).

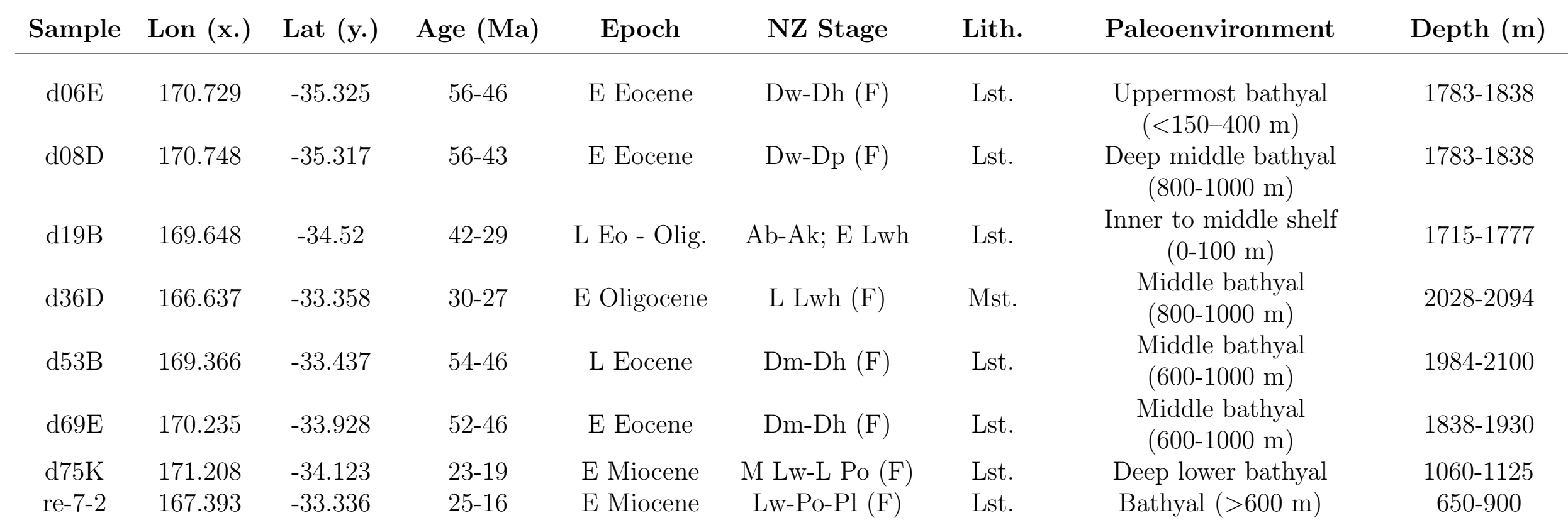




\subsubsection{TAN1312 Site D43}

Samples were dredged from 'Anticline A' of Bache et al. (2014c) in 1783-1838 m water depth, where Seismic Unit 4 (U4) is exposed at the seabed (Figure 3.3A). Samples d6E and d8D are Eocene limestones. Based on carbonate-grain size, they are specifically coarse, bioclastic packstones (Browne et al., 2016). Typical faunal assemblages contain large (>millimetrescale) skeletal debris, including material derived from bryozoans, bivalves, echinoderms, gastropods, algae, rare sponge spicules and common foraminifera (Browne et al., 2014, 2016). Presence of planktic species Morozovella lenisformis, Acarinina primitive and benthic Bulimina subbortonica and Buliminella browni in sample d6E gives a Waipawan to Heretaungan (Dw-Dh; early to middle Eocene) age of 56-46 Ma. Inclusion of Vulvulina zespinosa in sample d8D gives a Waipawan to Porangan (Dw-Dp; early to middle Eocene) age of 56-43 Ma (Browne et al., 2014).

Foraminiferal fauna were poorly preserved and yield conflicting paleodepths. Benthic fauna contains Vulvulina zespinosa in d8D, indicating a middle bathyal (800-1000 m) paleodepth, although the bulk of fauna seem shallower (Browne et al., 2014). A planktic abundance of $<15 \%$ indicates an inner neritic water mass. Benthic fauna contains Buliminella browni, Melonis maorica and Discorbinella apposita in d6E indicating that paleodepth was probably uppermost bathyal $(200-400 \mathrm{~m})$, and $<30 \%$ planktic adundance indicate an outer neritic water mass (Browne et al., 2014). Larger foraminifera were also recovered (Asterocyclina) indicating that material from the photic zone is present, possibly shallower than 150 m. Paleoenvironmental contradictions suggest these fauna are reworked.

Seismic Unit 4 (U4) contains benthic foraminifera that provide variable water depths. Sample d6E indicates a relatively shallow-water paleodepth, whereas sample d8D indicates a middle bathyal paleodepth. Based on the position of sample d6E to seismic data, it is inferred to represent the upper part of $\mathrm{U} 4$ and hence records progressive uplift, and subsequent downslope transport during deposition at 56-43 Ma. This syntectonic interpretation is consistent with wave ravinement of folded strata near West Norfolk Ridge, which may have acted as a catalyst for downslope reworking of shallow water fauna to bathyal depths. Recovery of multiple ages and paleodepths possibly result from mass-wasting of younger formations downslope, and these rocks are amalgamated in the dredge with older samples; which is an inherent uncertainty with dredging (Browne et al., 2016). 

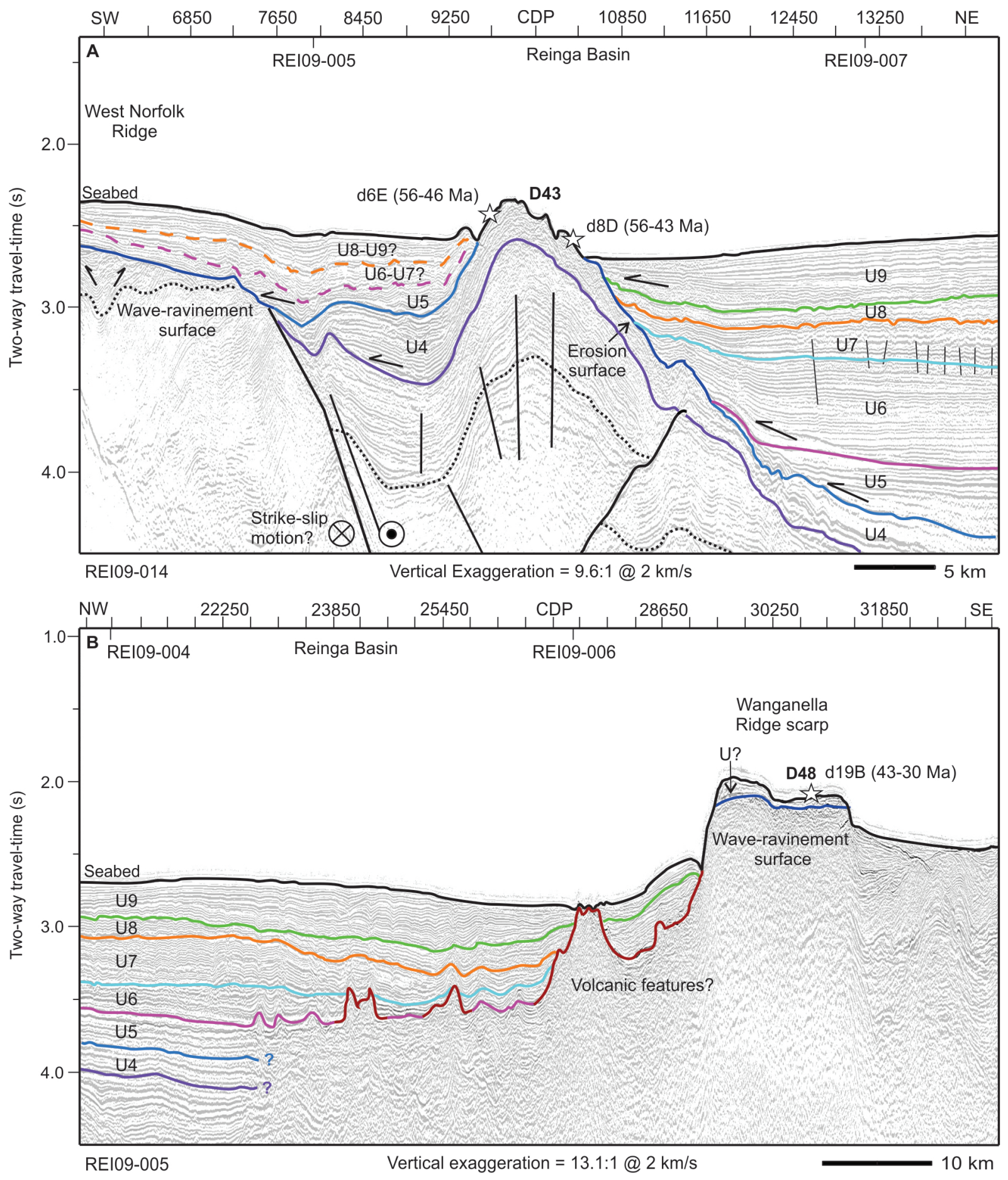

Figure 3.3: (A) Interpreted part of seismic reflection line REI09-014 showing the location of TAN1312 dredge site D43 and samples d6E and d8D. Dredges are early to middle Eocene bioclastic limestones that correspond to Seismic Unit (U4). The northeast limb of the anticline is subject to slope erosion by gravity flow during growth. (B) Interpreted part of seismic reflection line REI09-005 showing the location of TAN1312 dredge site D48 and sample d19B. Dredges are difficult to relate to seismic-stratigraphy, but a flat erosion surface overlain by undeformed shallow water limestone along strike from (A). See Figure 3.2 for location of seismic sections. 


\subsubsection{TAN1312 Site D48}

Samples were dredged on a scarp of Wanganella Ridge in 1715-1777 m water depth above a wave ravinement surface identified on seismic data (Figure 3.3B). Sample d19B is a bioclastic limestone that contains detrital sand-sized grains predominantly comprised of quartz, but also feldspar, minor chert and alkali olivine basalt rock fragments (Browne et al., 2016). Four specimens of Globigerinatheka index and a single Acarinina collactea were found, indicating an age of 36-34 Ma. However, a number of benthic fauna have younger age ranges (Discorotalia tenuissima, Bolivina lapsus, Bolivina anastomosa, Buliminella missilis and Victoriella conoidea), suggesting the sample has a dominant early to late Whaingaroan (Lwh; late Eocene-early Oligocene) age of 36-30 Ma, with a component of reworked Eocene material of age 43-38 Ma (Browne et al., 2014). Inclusion Operculina cf. complanata and Ehrenbergina sp. in sample d19G indicates contamination of Otaian to Clifdenian (Po-Sc; early to middle Miocene) microfossils.

Benthic fauna in both samples are dominated by shallow water forms (Amphistegina sp, Lepidocyclina sp., Mississippina concentrica, Wadella globiformis, Victoriella conoidea, Discorotalia tenuissima, Cribrorotalia sp., Elphidium charlottense), indicating an inner to middle shelf paleodepth (Browne et al., 2014). Planktic abundance of $40 \%$ indicates outer neritic water conditions.

Wanganella Ridge scarp is truncated by a wave ravinement surface and overlain by undeformed limestone deposited in shallow-water during the late Eocene to early Oligocene. Ties to a seismic unit is difficult, however, sampled sediment indicates that the onset of deposition was middle Eocene (43-38 Ma), shallow-water conditions were maintained until this location subsided to present-day depths from 36-30 Ma. This is constrained by the youngest age of shallow water fauna at this location.

\subsubsection{RE9032 Site RE7}

Sample RE9302-7-2 is a bathyal foraminiferal limestone, dredged off central Wanganella Ridge in 650-900 m water depth (Figure 3.4A). Foraminiferra indicate a Waitakian to Altonian (LwPl; latest Oligocene to early Miocene) age of 25-16 Ma (Herzer et al., 1997), and a bathyal (200-2000 m) paleodepth. Dredge samples are correlated to U6, as UB5 is inferred to be coeval with the seabed of Wanganella Ridge, which is suggested to have been in bathyal water depths since 25-16 Ma. 

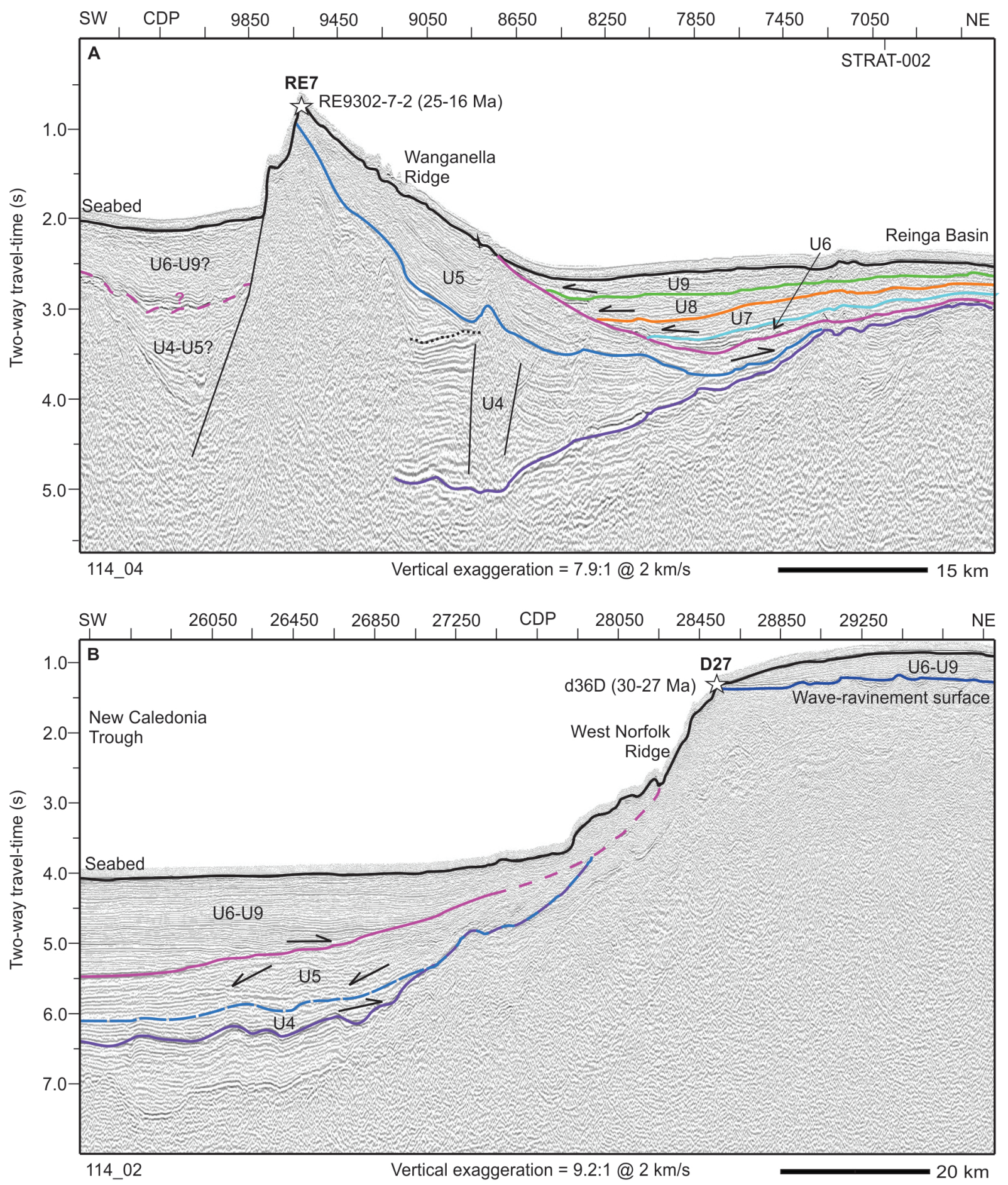

Figure 3.4: (A) Part of seismic reflection line 114-04 across Wanganella Ridge showing the location of dredge site RE7 and individual sample RE9302-7-2. Dredge RE9302-7-2 is a Miocene limestone and corresponds to Seismic Unit 6 (U6) as UB5 is equivalent to the seabed. (B) Part of seismic reflection line 114-02 across part of New Caledonia Trough and West Norfolk Ridge, showing the location of dredge site D27. Sample d36D is an undeformed deep-water mudstone corresponding to Seismic Unit 6 (U6), overlying a flat erosion surface. See Figure 3.2 for location of seismic sections. 


\subsubsection{TAN1312 Site D27}

Samples were dredged above a wave ravinement surface on the western scarp of West Norfolk Ridge at 1340-1610 m water depth (Figure 3.4B). Sample d36D is an Oligocene calcareous mudstone. Planktic fauna contain Globigerina euapertura, Globigerina brevis, and Paragloborotalia semivera, giving a late Whaingaroan (Lwh; early Oligocene) age of 30-27 Ma. Contamination of younger Opotian (Wo; Early Pliocene) age microfossils is indicated by presence of abundant planktic fauna containing Globorotalia limbata, Globorotalia puncticulata, Globorotalia pliozea and Dentoglobigerina altispira.

Benthic fauna contains Globocassidulina cuneata, Gyroidinoides meosoldanii, Lenticulina pusilla, Pleurostomella brevis, Tritaxia instar and Vulvulina pennatula, indicating a middle bathyal paleodepth. Planktic abundance of $99 \%$ indicates fully oceanic water conditions during deposition (Browne et al., 2014). West Norfolk Ridge is truncated by a wave ravinement surface and interpreted to be overlain by undeformed mudstone of Seismic Unit 6 (U6), on the basis of similar seismic character of U6 in New Caledonia Trough. No shallow water signals are found, inferring a significant hiatus between wave ravinement and deposition in middle bathyal depths. Subsidence from wave base to middle bathyal depths by $30 \mathrm{Ma}$ is inferred for this location.

\subsubsection{TAN1312 Site D21}

Samples were dredged from 'Anticline C' of Bache et al. (2014c) in northwest Reinga Basin in 1984- $2100 \mathrm{~m}$ water depth, where Seismic Unit 4 (U4) is exposed at the seabed (Figure 3.5A). Sample d53B is an Eocene wackestone, with fossiliferous micrite and sparse biomicrite grains with skeletal material restricted to planktic foraminifera (Browne et al., 2016). Dark irregular masses in thin-section indicate manganese-oxide preciptiation within the sample (Browne et al., 2016). Planktic fauna contain Morozovella crater, Morozovella lensiformis, Acarinina primitive and Subbotina lineperta indicating a Mangaorapan to Heretaungan (DmDh; early to middle Eocene) age of 54-46 Ma (Browne et al., 2014).

Abundant planktic fauna and radiolaria indicate a near full oceanic setting. Benthic fauna are sparse, but presence of Nuttallides indicates U4 strata were deposited in middle bathyal paleodepths (Browne et al., 2014). Deposition of U4 pre-dates folding, therefore deformation that exposed U4 at the seabed occurs after the youngest biostratigraphic age at this location (46 Ma). Based on similar seismic character, this interpretation can be correlated along strike to infer the timing of deformation in northern-most Reinga Basin (Figure 3.5B). 

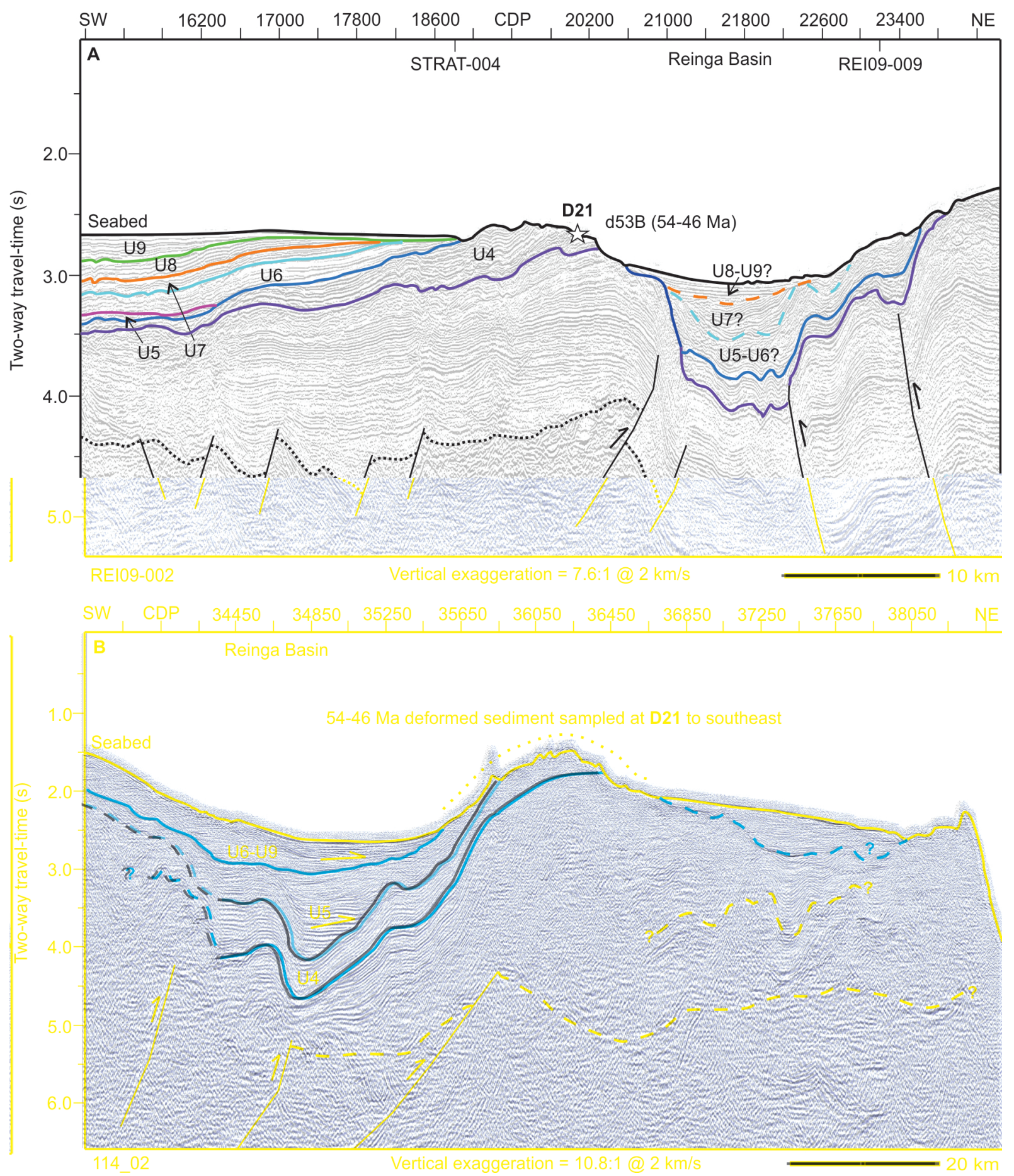

Figure 3.5: (A) Part of seismic reflection line REI09-002 showing similar northeast-verging deformation. Dredged micritic limestone of U4 contain benthic fauna that indicate deposition in middle bathyal water depths. The onset of folding and uplift is constrained to a middle Eocene age of 46 Ma. (B) Part of seismic reflection line 114-02 across northern Reinga Basin, showing northeastverging deformation and folding of Seismic Unit 4 (U4) tied to dredge samples from D21 along strike to the southeast. See Figure 3.2 for location of seismic sections. 


\subsubsection{TAN1312 Site D13}

Samples were dredged on 'Anticline D' of Bache et al. (2014c) in 1836-1930 m water depth, where Seismic Unit 4 (U4) is exposed at the seabed (Figure 3.6A). Sample d69E is an Eocene wackestone with coarse-grained micrite, possibly reflecting recrystallisation to microspar (Browne et al., 2016). Diverse and abundant planktic fauna contain Subbotina hornibrooki, Acarinina primitive and Globanomalina australiformis, indicating a Mangaorapan to Heretaungan (Dm-Dh; early to middle Eocene) age of 54-46 Ma (Browne et al., 2014).

Benthic fauna contain Nuttallides, Allomorphina and Stilostomella, indicating deposition in a deep middle bathyal paleodepth (Browne et al., 2014). Planktic abundance of 95\% indicates an open oceanic water mass. Similar to Site D21, deposition of U4 pre-dates folding, therefore timing of deformation is constrained by the youngest biostratigraphic age at this location to occur after $46 \mathrm{Ma}$. Presence of several Globorotalia species, indicate contamination by Castlecliffian (Wc; Pleistocene) to Recent age microfossils (Browne et al., 2014).

\subsubsection{TAN1312 Site D5}

Samples were dredged on southwestern South Maria Ridge in 1125-1060 m water depth, conspicuously located above a wave ravinement surface and South Maria Allochthon (Figure 3.6B). Sample d75k is a Miocene coarse, bioclastic grainstone. Faunal assemblage comprises echinoderm, bryozoan and bivalve material, where the intra-particle dissolution of pores likely leads to the measured porosity of 6.4-23.5\% (Browne et al., 2016). This sample contains diverse mid-shelf fauna, warm-water epifaunal bivalves and warm-water gastropods. Planktic fauna contain Globoquadrina dehiscens, Globigerina woodi and Globigerina connecta, indicating a middle Waitakian to Otaian (Lw-Po; latest Oligocene to early Miocene) age of 23-19 Ma (Browne et al., 2014).

A single specimen of Tritaxilina zealandica gives a paleodepth of deep lower bathyal (> $1500 \mathrm{~m}$ ). Given the ratio of mid shelf to bathyal fauna and the high porosity of the sample, it is likely this represents contamination; possibly reworked from the allochthon which mainly comprises bathyal sediments based on samples from older units. Planktic abundance of $40 \%$ indicate an outer neritic water mass. A wave ravinement surface, correlated across South Maria Ridge, is overlain by undeformed limestone suggesting that the ridge has subsided from mid shelf to present-day bathyal conditions since 23 Ma. 


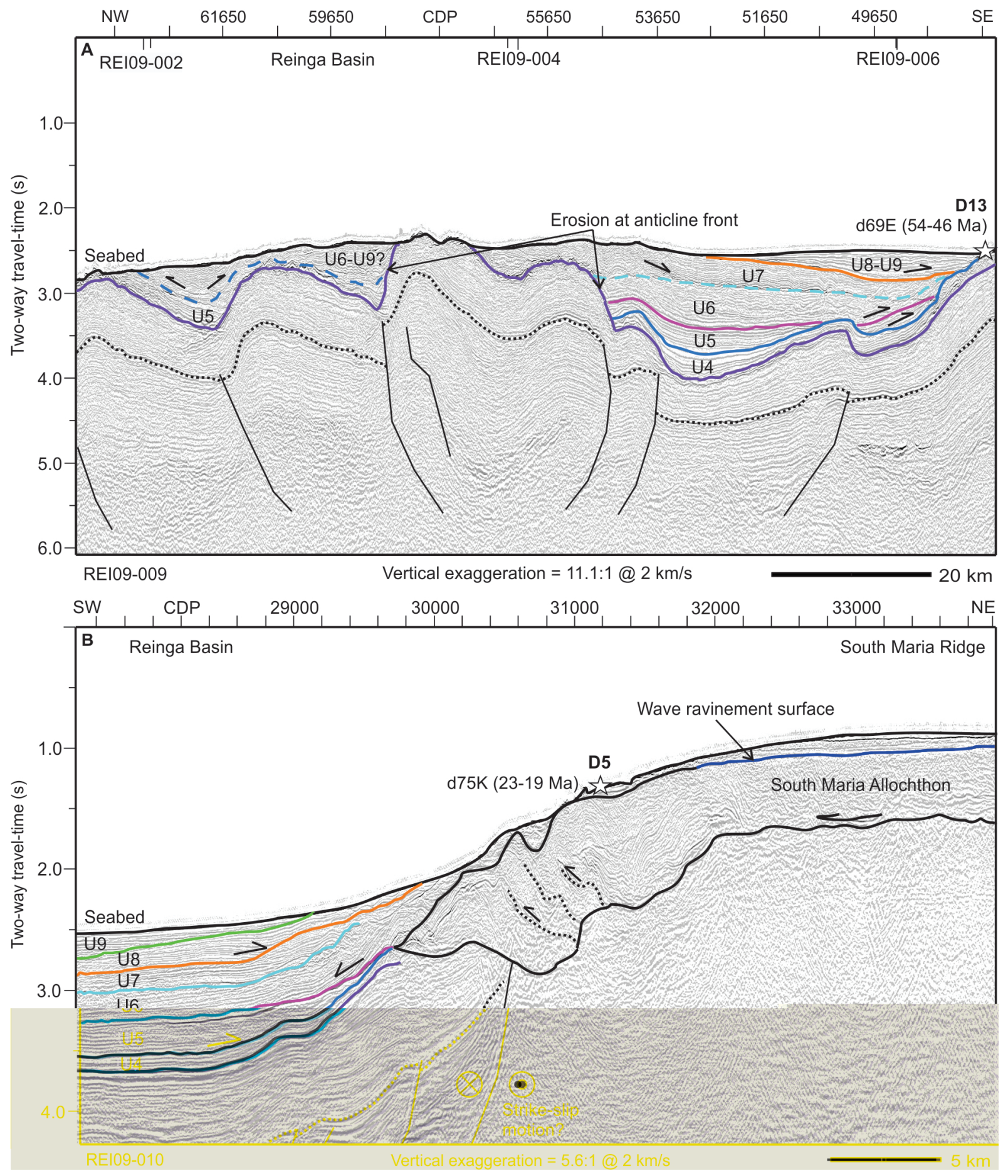

Figure 3.6: (A) Part of seismic line REI09-009 showing north-northwest and east-southeast verging folds. Dredged early-middle Eocene mudstone and limestone correspond to Seismic Unit 4 (U4). The onset of folding is constrained to a middle Eocene age of 46 Ma. (B) Part of seismic line REI09-010 showing a southwest directed allochthon pertinent to dredge site D5. A dredged early Miocene deep-water limestone is separated from the allochthon by an erosion surface. See Figure 3.2 for location of seismic sections. 


\section{$3.3 \quad \mathrm{U} 1508$}

IODP Site U1508 was drilled in August 2018 in 1609 m water depth and is located c. $130 \mathrm{~km}$ west of the northern tip of New Zealand (Figure 3.2). This location along the northeastern margin of Reinga Basin contains folded strata of Seismic Unit 4 and is inferred to be near the southern end of where subduction initiation occurred (Bache et al., 2012a,b; Browne et al., 2016; Sutherland et al., 2017). The site was chosen to sample a proximal record of deformation, uplift, subsidence and early arc volcanism through a package of flat-lying Neogene sediments overlying folded and fanning Paleogene strata (Sutherland et al., 2019a).

The recovered sedimentary sequence consists of $701.9 \mathrm{~m}$ of Pleistocene to early Eocene heterogeneous sediments, subsequently subdivided into three lithostratigraphic units (Figure 3.7, 3.8). Three main sedimentary lithologic classes are defined by Sutherland et al. (2019b).based on the primary origin of the sediment constituents (but not depositional processes): Biogenic, $>50 \%$ carbonate, chemical and biogenic particles; Siliciclastic, $>50 \%$ siliciclastic particles, $<25 \%$ volcanic particles, and $<50 \%$ biogenic particles; Volcaniclastic, $>25 \%$ volcanic particles. For sedimentary and volcaniclastic naming conventions see Sutherland et al. (2019b) and their Figure F7.

\subsubsection{Time-to-depth}

Velocity data were recorded by downhole wireline logs at Site U1508. Acoustic impedance, reflection co-efficients and a synthetic seismogram were calculated from bulk density and velocity measurements on cores and from the wireline velocity (Figure 3.7). Where the synthetic seismogram correlates well with traces extracted from multi-channel seismic data on line REI09-012, two-way-time depth points were selected (Sutherland et al., 2019a). Twoway-time $(t w t)$ is calculated from depths $(z)$ below seafloor using the numerical solution $z=326.77 t w t^{2}+781.74 t w t$, and is subsequently plotted as a function of depth to derive a single two-way-time versus depth relationship (Figure 3.7).

It is important to note that the lowermost mapped seismic horizon in this study, UB3, may not be encountered in Site U1508 based on the synthetic. The synthetic seismograph does not correlate well to this reflection (Sutherland et al. 2019a; their Figure 35). Based on the time-depth relationship, the base of the borehole is $37.8 \mathrm{~m}$ off intersecting horizon UB3 (UB3*; Table 3.3). However, this can be speculated due to a large increase $P$-wave velocity and sediment hardness at the base of the borehole with a stratigraphic change from nannofossil chalk to nannofossil limestone, giving a positive polarity reflection (Figure 3.7). 


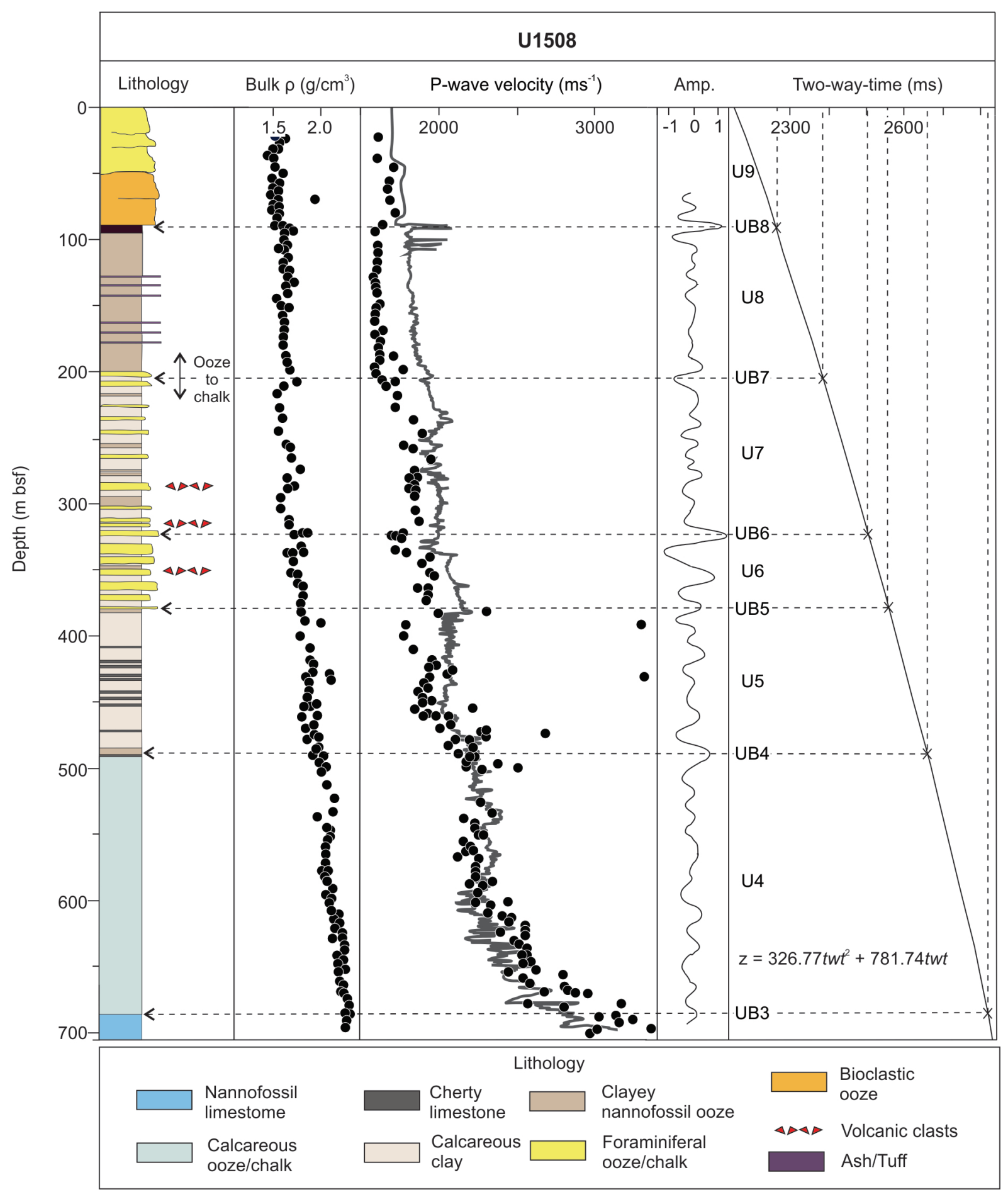

Figure 3.7: Two-way-time with depth relationship for IODP Site U1508 in Reinga Basin (see Figure 3.2 for location). Lithology is from macro and microscopic core descriptions. The ooze to chalk transition is indicated by opposite-facing arrows. Bulk density $\left(\mathrm{g} / \mathrm{cm}^{3}\right), P$-wave velocity $\left(\mathrm{ms}^{-1}\right)$ are measured in laboratory (black dots) and from wireline logging (grey line). Extracted trace is from multi-channel seismic data at CDP 8470. Two-way-time is derived from the wireline $P$ wave velocity and depth relationship. Dashed lines indicate the two-way-time and depth relationship of interpreted horizons in Chapter 2, and are summarised in Table 3.3. Note UB9 correlates with the seabed at $0 \mathrm{~m}$ bsf. 
Table 3.3: Seismic reflectors, two-way-times (TWT), and depths (Z) for identified reflectors on multi-channel seismic data at U1508. Major seismic reflector depths are estimated from Figure 3.7. Based on the synthetic seismogram, reflector UB3 is not encountered at Site U1508 and is 37.8 $\mathrm{m}$ away from the base of the borehole (UB3*). An age of $54 \mathrm{Ma}$ is inferred from extrapolating sedimentation rates at the base of the borehole into underlying sediment (Sutherland et al., 2019a).

\begin{tabular}{cccccc} 
Reflector & TWT $(\mathbf{s})$ & $\mathbf{Z ~ ( m ~ b s l ) ~}$ & TWT bsf (s) & $\mathbf{Z ~ ( m ~ b s f ) ~}$ & Age (Ma) \\
\hline SF & 2.156 & 1609 & 0 & 0 & 0 \\
UB8 & 2.269 & 1701.9 & 0.113 & 92.8 & 5 \\
UB7 & 2.398 & 1817.8 & 0.243 & 208.8 & 12 \\
UB6 & 2.514 & 1930.7 & 0.358 & 321.7 & 23 \\
UB5 & 2.568 & 1987.2 & 0.413 & 378.2 & 34 \\
UB4 & 2.668 & 2094.9 & 0.512 & 485.9 & 39 \\
UB3 & 2.838 & 2294.1 & 0.682 & 685.1 & 48 \\
UB3* & 2.882 & 2348.7 & 0.726 & 739.7 & $54 ?$
\end{tabular}

\subsubsection{Lithological Unit I (0-90 m bsf)}

Lithological unit descriptions for Site U1508 are based on those of Sutherland et al. (2019a) and their unit names are adopted. For the seismic stratigraphic equivalent see Figures 3.7 and 3.8.

Lithological Unit I (U9) comprises $90 \mathrm{~m}$ of Pleistocene to Pliocene (0-5 Ma) foraminiferal ooze, with varying amounts of nannofossils, and coarse-grained bioclasts, predominantly composed of 1-5 mm bryozoans, which are relatively constant throughout with an apparent cyclic trend (Sutherland et al. 2019a; their Figure 43). Petrophysical data show low density, high porosity and $P$-wave velocity values for this unit (Sutherland et al., 2019a). An abrupt change in sedimentation from foraminiferal ooze with bioclasts to nannofossil ooze, a decrease in porosity and velocity, and an increase in natural gamma ray, and bulk density values yield an increase in acoustic impedance and defines the Unit I-II boundary (Figure 3.7). On the basis of calcareous nannofossils, the boundary corresponds to a $\sim 2$ Myr hiatus (H4), and seismic reflection UB8 (Figure 3.8).

Lithological Unit I contains benthic fauna Cibicidoides bradyi, Cibicides robertsonianus, Nuttallides umbonifera, Planulina wuellerstorfi, stilostomellids, and Pleurostomella spp., indicating deposition in deep middle bathyal to lower bathyal paleodepths. However, shelf or upper bathyal benthic foraminifers $(0-600 \mathrm{~m})$, including Ehrenbergina, Cibicides vortex, Notorotalia spp., and Elphidium spp., are sporadically present (Sutherland et al., 2019a), likely indicating some redeposition of material from the nearby slope (Figure 3.9). 


\subsubsection{Lithological Unit II (90-380 m bsf)}

Lithological Unit II comprises $290 \mathrm{~m}$ of Pliocene to late Oligocene calcareous ooze. Unit IIa (late Miocene to Pliocene) is nannofossil-dominated, and Unit IIb (late Oligocene to middle Miocene) is foraminifera-dominated (Figure 3.7, 3.8).

Lithological subunit IIa (U8) comprises 110 m (90-200 m bsf) of late Miocene to Pliocene (5-12 Ma) clayey nannofossil ooze and chalk with common to abundant foraminifera (Sutherland et al., 2019a). Five cm-thick beds containing dominant (> 50\%) volcanic material are observed between 135 and $178 \mathrm{~m}$ bsf (Figure 3.7). The highest stratigraphic occurrence of sharp-based foraminiferal chalk with lithic grains coincides with increasing porosity, and decreasing density and velocity. This yields a decrease in acoustic impedance and defining the Unit IIa-IIb boundary. The boundary corresponds to a $\sim 2$ Myr hiatus (H3) on the basis of calcareous nannofossils Catinaster coalitus and Calcidiscus premacityrei, the 'oozeto-chalk' transition, and seismic reflection UB7 (Figure 3.8). Abundant pelagic palynomorphs of Impagidinium spp., Nematosphaeropsis labyrinthus, and Batiacasphaera spp., indicate an open-ocean setting with high amounts of offshore transport (Sutherland et al., 2019a).

Lithological subunit IIb (U7 and U6) comprises 180 m (200-380 m bsf) of late Oligocene to middle Miocene (12-34 Ma) coarser-grained foraminiferal ooze and chalk with lithic and volcanic grains. Natural gamma ray data show high-amplitude variations, where high values presumably represent coarser grained intervals comprising silicate minerals and glauconite; and lower values representing finer, biogenic-rich sediment (Sutherland et al., 2019a). At $321 \mathrm{~m}$ bsf, an irregular, bioturbated erosional surface sharply separates medium sand-sized foraminiferal ooze above from nannofossil chalk below. Petrophysical data show a downhole increase in natural gamma ray and density, giving an increase in acoustic impedance. In addition, this boundary corresponding to a $\sim 5$ Myr hiatus (H2) and seismic reflection UB6 (Figure 3.8). Below this late Oligocene to early Miocene hiatus (23-18 Ma), there is a particularly strong shallow-water, and land-proximal signal found (see Sutherland et al. (2019b) for taxa).

A peak in silicate minerals, volcanic grains and glauconite occurs between $(\sim 321-337 \mathrm{~m}$ bsf). Below this, silicate minerals and glauconite decrease, resulting in a clean foraminiferal chalk (i.e. no terrestrial input) in the lowest part of subunit IIb (Sutherland et al., 2019a). Volcanic clasts within subunit IIb are located between 250-350 m bsf and are described as silicate minerals (quartz and plagioclase) and lithic grains (clinoptilolite-zeolite) between 250$260 \mathrm{~m}$ bsf. The last stratigraphic occurrence of coarse nannofossil-rich foraminiferal chalk and an abrupt downhole change into clayey nannofossil chalk at $380 \mathrm{~m}$ bsf, is shown by an increase in density and velocity in petrophysical data (Figure 3.7). This corresponds to a 6 Myr hiatus (H1; 34-28 Ma), seismic reflection UB6, and the Oligocene-Eocene boundary 
(Figure 3.8).

Conspicuously located above this hiatus is a late Oligocene palynological assemblage that lacks pelagic components; a peak in shallow-water ostracods; and large amounts of terrestrial sporomorphs that indicate significant amounts of offshore transport from a nearby landmass. Lithological Unit II contains in-situ benthic fauna Hopkinsina mioindex, Tritaxilina zealandica and Tritaxia instar, suggesting deposition in lower bathyal paleodepths in the Miocene. Oligocene strata contain taxa that are common at lower neritic to bathyal, and upper bathyal depths, but taxa are primarily middle bathyal (Sutherland et al., 2019a). Biostratigraphic and seismic interpretations are aligned - a near-by wave ravinement surface truncates folded strata beneath South Maria Ridge, leading to subsequent downslope transport of reworked shallow-water taxa to bathyal depths recorded at the borehole site (Figure $3.9)$. 


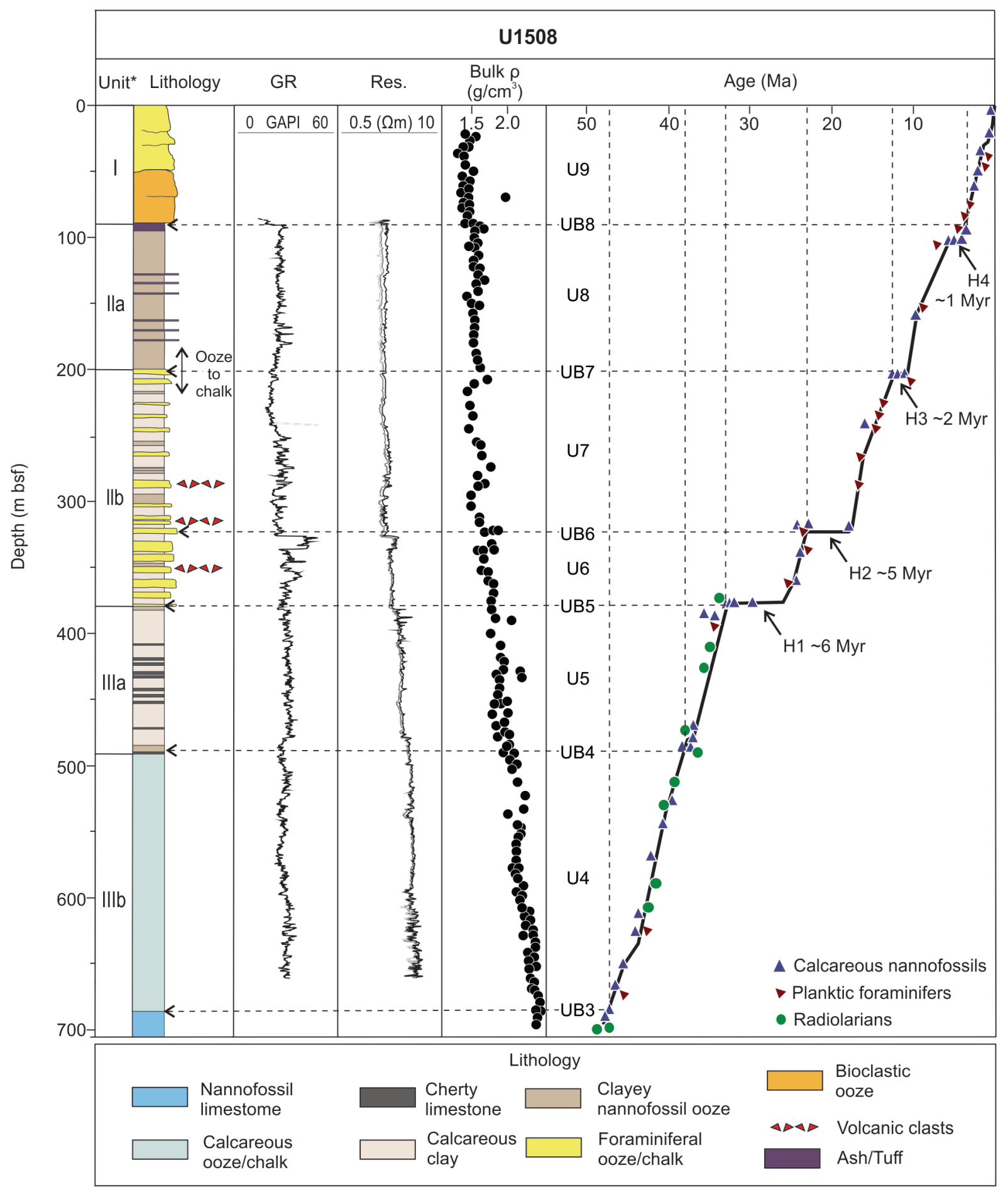

Figure 3.8: Age with depth relationship and downhole geophysical data for IODP Site U1508 in Reinga Basin (see Figure 3.2 for location). Lithological unit nomenclature is adopted from Sutherland et al. (2019a). Lithology is from macro- and microscopic core descriptions. Wireline data: GR, gamma-ray; Res., resistivity $(\Omega \mathrm{m})$; Bulk $\rho$, bulk density. Age model (in years Ma) is derived from calcareous nannofossil, planktic foraminifera and radiolaria samples (for method - see Sutherland et al. 2019b. Labels H1, H2, H3 and H4 indicate hiatuses in the model, and are referred to in text. Dashed lines indicate the age with depth relationship of interpreted horizons in Chapter 2, where depth is determined by the time with depth relationship in Figure 3.7. 


\subsubsection{Lithological Unit III (380-702 $\mathrm{m}$ bsf)}

Lithological Unit III comprises $322 \mathrm{~m}$ of early to late Eocene clayey nannofossil chalk and moderately bioturbated nannofossil chalk, and is divided into Subunits IIIa and IIIb (Figure $3.7,3.8)$.

Lithological subunit IIIa (U5) comprises $114 \mathrm{~m}$ (380-494 m bsf) of middle to late Eocene (34-39 Ma) moderately-to-heavily bioturbated clayey nannofossil chalk, common foraminifera and $40 \mathrm{~cm}$ siliceous intervals of cherty limestone (Figure 3.8). Subtle peaks in resistivity (Figure 3.8) coincide with areas of poor core recovery, suggesting this interval (380-420 m bsf) is subject to heavy silicification (Sutherland et al., 2019a). Prominent cherty limestone layers are 1-6 cm thick and occur at intervals of tens of centimetres between 380-490 m (Figure 3.8). Small-scale deformation is observed below $475 \mathrm{~m}$ bsf, with tilting of laminae, at a maximum tilt of $10^{\circ}$, and fractures at $35^{\circ}$ to $45^{\circ}$ to the bedding plane; tilting is consistent with deformation observed in seismic data (Figure 3.9). Despite the lack of petrophysical signals downhole, a stratigraphic change from clayey nannofossil chalk with cherty limestone to nannofossil chalk and limestone corresponds to an increase in acoustic impedance and seismic reflection UB4 (Figure 3.7).

Lithological subunit IIIb (U4) comprises 208 m (494-702 m bsf) of early to middle Eocene (39-48 Ma) nannofossil chalk and limestone, differentiated from IIIa by a lower clay content at $494 \mathrm{~m}$ bsf, and a decrease in natural gamma ray signal (Figure 3.8). Carbonate content significantly increases downhole over a $27.1 \mathrm{~m}$ interval (495.6-522.7 m) from $53 \%$ to $81 \%$ (Sutherland et al., 2019a). Small-scale deformation is observed, dominated by tilted sediment, ranging from $12^{\circ}$ in the upper half of Subunit IIIb to $15^{\circ}$ in the lower $60 \mathrm{~m}$, which is consistent with deformation seen on seismic data (Figure 3.9).

Lithological Unit III contains fauna of variable paleodepths. Early to middle Eocene samples contain benthic fauna of Anomalina aotea and C. dohmi, indicating a lower bathyal paleodepth. Late Eocene samples contain primarily bathyal taxa (Anomalina visenda and Cibicides ihungia), but also include T. bradyi and B. tuxpamensis, which indicate paleodepths of lower neritic to bathyal (100-200 m) and upper bathyal (200-600 m), respectively. The presence of $U$. rippensis and Euuvigerina bortotara indicate a lower middle bathyal paleodepth. This suggests uplift on the order of a few hundred metres, and reworking by downslope transport in the upper part of Unit III (Sutherland et al., 2019a). 


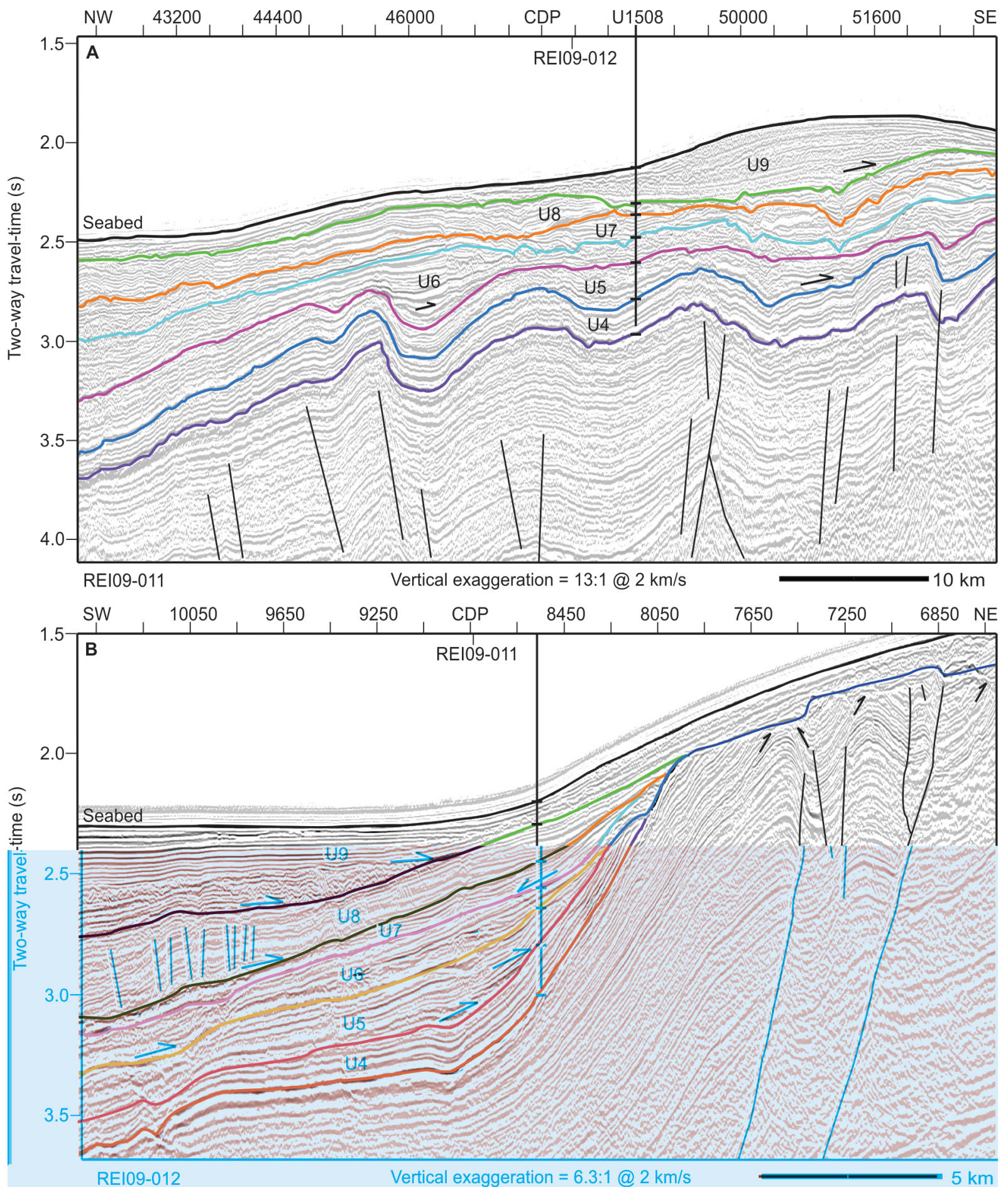

Figure 3.9: Seismic reflection lines (REI09-011 and REI09-012) showing Site U1508 ties to seismic data. (A) U4 and U5 are folded. U6 fills a small-scale fold to the northwest, but is condensed at Site U1508. U7-U9 are of variable thickness along strike. (B) U4 and U5 are folded and deformed in the borehole. U5-U8 contain fanning reflectors and variable amounts of shallow-water and landproximal signals reworked to bathyal depths, consistent with the nearby wave ravinement surface truncating older, folded strata. U9 drapes older, deformed units. Figure location is shown in Figure 3.2 . 


\subsection{Waka Nui-1}

Waka Nui-1 was drilled in April 1999 in 1445 m water depth and is located c. 90 km west of Kaipara Harbour in Northland (Figure 3.2). Targeting interpreted Cretaceous syn-rift coal measures draping across a tilted fault-block (Milne and Quick, 1999; Stagpoole, 2011), the well reached a total depth (TD) of $3681 \mathrm{~m}$, and was devoid of oil shows. No post-drilling wireline log data, including sonic log and check-shot data were recorded (Milne and Quick, 1999). Available logging-while-drilling logs are natural gamma ray, resistivity, bulk density and neutron porosity. Offshore Northland Basin lithostratigraphy and biostratigraphy is solely based on mudlog and cutting samples from Waka Nui-1 (Milne and Quick, 1999; Strong et al., 1999). Lithological units between seismic reflections UB3 and UB7 are discussed.

\subsubsection{Time-to-depth}

Time-to-depth conversion is usually achieved from sonic logs that measure seismic velocity of strata of the borehole wall, or from check-shot data that measure travel-time of seismic waves in strata adjacent to the well (Sheriff and Geldart, 1995). Stagpoole (2011) developed a two-way-time to depth relationship from analysis of stacking velocities on nearby 2D seismic reflection lines (CNL95a-034 and STRAT-006) and logging-while-drilling logs in absence of check-shot data. Interval velocities and two-way-time thickness approximate interval thickness, which were summed to give a depth below sea floor and subsequently plotted as a function of two-way-time to derive a single two-way-time versus depth relationship: $z=169.95 t w t^{2}+839.16 t w t$, where $z=$ depth, and $t w t=$ two-way-time to the reflector, respectively (Figure 3.10).

Stagpoole (2011) created a synthetic seismogram by combining interval velocities with density logs, which correlates well with seismic traces extracted from multi-channel seismic data, reproducing significant reflection events at the Waka Nui-1 well location. The synthetic was used for fine-tuning the two-way-time with depth relationship. There is a disagreement between reflections identified by Stagpoole (2011), and reflections UB4 and UB6 of this study (Figure 3.10). Disparity may arise from the method of picking reflections at the borehole site based on seismic configurations. Based on principles of seismic stratigraphy, UB4 is not a significant reflector in Northland Basin (e.g. Section 2.3.3), and is picked on loop-ties from Reinga Basin. In contrast, UB6 is a significant reflector (e.g. Section 2.3.7), but does not correspond to a significant event at Waka Nui-1. The difference in depth, and ultimately age, is considered negligible and picks from the seismic-to-well method are used herein (Table $3.4)$. 


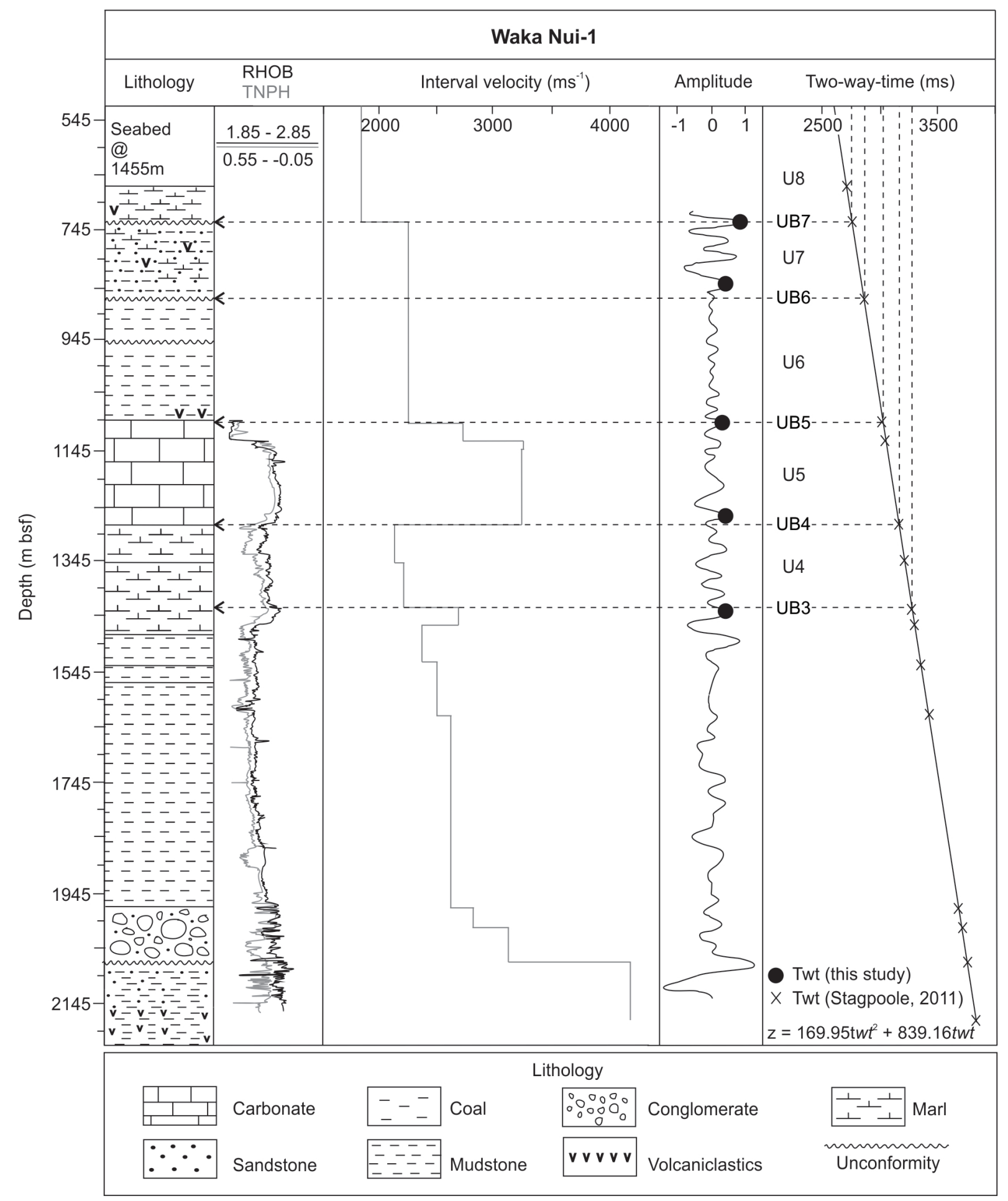

Figure 3.10: Two-way-time with depth relationship for the Waka Nui-1 well in Northland Basin (see Figure 3.2 for location). Interval velocity is derived from stacking velocities during seismic data processing on nearby seismic lines CNL95a-034 and STRAT-006. Extracted seismic trace is from CDP 1630 on line CNL95a-034. Crosses indicate control points for the two-way-time with depth relationship and correlate to changes in interval velocity. Dashed lines indicate the two-waytime with depth relationship of interpreted horizons in Chapter 2, based on the synthetic model of Stagpoole (2011). Circles indicate two-way-time picks made in this study and are summarised in Table 3.4 . 
Table 3.4: Seismic reflectors, two-way-times (TWT), and depths (Z) for identified reflectors on multi-channel seismic data at Waka Nui-1. Major seismic reflector depths are estimated from Figure 3.10 .

\begin{tabular}{cccccc} 
Reflector & TWT (s) & $\mathbf{Z}(\mathbf{m}$ bsl) & TWT bsf (s) & $\mathbf{Z ~ ( m ~ b s f ) ~}$ & Age (Ma) \\
\hline SF & 1.940 & 1455 & 0 & 0 & 0 \\
UB8 & 2.387 & 1675 & 0.447 & 220 & 5 \\
UB7 & 2.792 & 2186 & 0.852 & 731 & 8 \\
UB6 & 2.883 & 2326 & 0.943 & 871 & 16 \\
UB5 & 3.040 & 2551 & 1.100 & 1096 & 25 \\
UB4 & 3.135 & 2740 & 1.195 & 1285 & 38 \\
UB3 & 3.301 & 2927 & 1.361 & 1472 & 48
\end{tabular}

\subsubsection{Lithological Unit 8 (671-731 m bsf)}

Lithological descriptions for Waka Nui-1 are based on those of Milne and Quick (1999) but seismic stratigraphic names are given for consistency (Figures 3.10 and 3.11).

First returns for the well occur at a depth of c. $671 \mathrm{~m}$ bsf, where a $60 \mathrm{~m}$ interval of marl was intersected. A stratigraphic break is identified at c. $731 \mathrm{~m} \mathrm{bsf}$, where a lithological change from unconsolidated marls, to moderately lithified marls with interbedded volcaniclastics of the Ariki Formation occurs (Stagpoole, 2011). Lithological Unit 8 contains benthic fauna Cibicides kullenbergi, Sigmoilopsis schlumbergeri, Sipouvigerina notohispida and occassional Vulvulvina spp., indicating a lower bathyal paleodepth (Strong et al., 1999).

Planktic fauna contain Globorotalia inflata-puncticulata and absence of Globorotalia nepenthes near $731 \mathrm{~m}$ bsf indicating an early Opotian (Wo; early Pliocene) age of $\sim 5 \mathrm{Ma}$ (Strong et al., 1999) above the break. First downhole appearance of Globorotalia miotumida and absence of Globoquadrina dehiscens indicates a missing Kapitean (Tk; latest Miocene) sequence, and a late Tongaporutuan (Tt; late Miocene) age of $\sim 7 \mathrm{Ma}$. UB7 is therefore represented by a $\sim 2$ Myr hiatus (H3) (Strong et al., 1999) (Figure 3.11). The seismic reflection is positive-polarity (e.g. an increase in acoustic impedance contrast), supported by a 405 $\mathrm{ms}^{-1}$ increase in interval velocity (Figure 3.10). 


\subsubsection{Lithological Unit 7 (731-871 m bsf)}

Lithological Unit 7 comprises 140 m of moderately lithified marl, with several minor interbedded calcareous claystone and sandstone stringers, and a minor volcaniclastic sandstone unit (Mohakatino Formation) (Milne and Quick, 1999). At $771 \mathrm{~m}$ bsf a thin, fine, sub-angular grained volcaniclastic tuff with olivine, feldspar and undifferentiated mafic minerals appears within the marl. Planktic fauna of Globoquadrina dehiscens and Globorotalia panda indicate the unit has an early Tongaporutuan (Tt; late Miocene) to Lillburnian (Sl; middle Miocene) age of 10-15 Ma. Lithological Unit 7 contains common benthic fauna of Cibicides kullenbergi and Triaxilina zealandica, indicating deposition in lower bathyal paleodepths beneath an oceanic water mass. Common Amphistegina sp. indicates minor seaward transport of inner-shelf foraminifera (Strong et al., 1999), which is consistent with downlap reflectors on seismic reflection data (Figure 3.12).

A condensed interval with an increase in marl content is identified between $857-867 \mathrm{~m}$ bsf. Below this boundary, Globorotalia miozera indicates a late Altonian (Pl; earliest Miocene) age of c. $16 \mathrm{Ma}$, suggesting a $\sim 1$ Myr hiatus (H2) (Strong et al., 1999). UB6 is therefore represented by a $\sim 1$ Myr hiatus, but there are no wireline or interval velocity changes to support a sequence boundary on seismic data (Figure 3.10). 


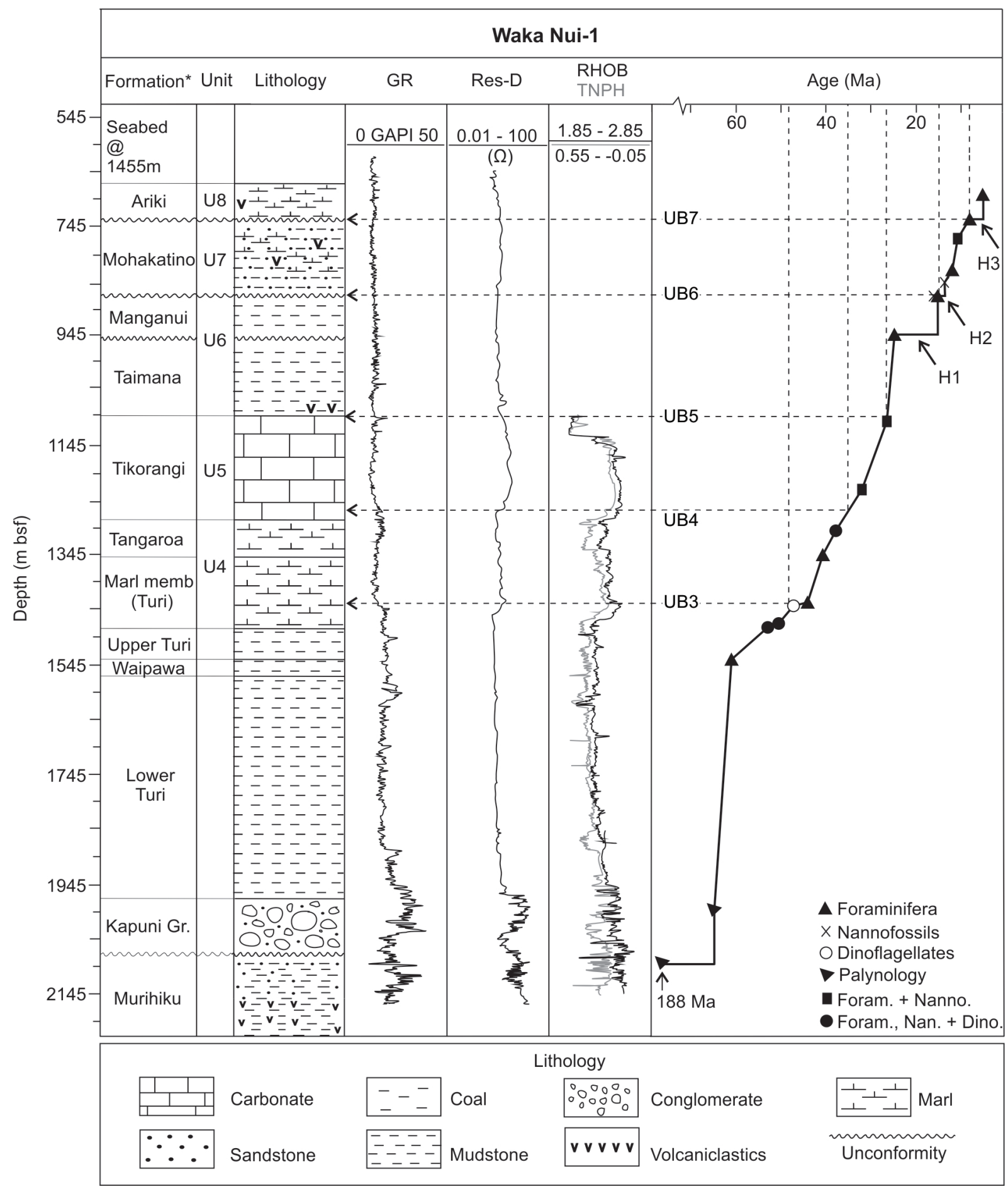

Figure 3.11: Age with depth relationship and downhole geophysical data for Waka Nui-1 well in Northland Basin (see Figure 3.2 for location). From left to right: Formation name, *assigned Taranaki Basin names by Stagpoole (2011); lithological and seismic units; interpreted lithologies from cuttings (Milne and Quick, 1999); GR, gamma ray; Res, resistivity; RHOB, bulk density $\left(\mathrm{g} / \mathrm{cm}^{3}, \mathrm{TNPH}\right.$, neutron porosity. Key at the bottom right indicates the taxonomic group used for chronological analysis based on biostratigraphy (Strong et al., 1999). Hiatuses referred to in text are shown by arrows. Dashed lines indicate the age of interpreted horizons in Chapter 2, and are summarised in Table 3.4. Depth is determined by the time with depth relationship in Figure 3.10. 


\subsubsection{Lithological Unit 6 (871-1096 m bsf)}

Lithological Unit 6 comprises $225 \mathrm{~m}$ of marl and calcareous siltstone with common mudstone and sandstone interbeds of Manganui and Taimana formations (Stagpoole, 2011). Planktic fauna of Globorotalia zealandica, Globerigerina euapertura and Globoquadrina dehiscens indicate the unit has an Altonian (Pl; early Miocene) to early Waitakain (Lw; latest Oligocene) age of 18.7-24 Ma (Figure 3.11). A $\sim 6$ Myr intra-unit hiatus is indicated by the absence of definitive late Waitakian and Otaian fauna at c. $941 \mathrm{~m}$ bsf (H1) (Strong et al., 1999). Below this hiatus, there is a notable downhole increase in mud content and first evidence of volcanic detritus at $1096 \mathrm{~m}$ bsf (Milne and Quick, 1999). Volcaniclastic grains are poorly sorted and dominantly angular to sub-angular, occurring in thin sandy-stringers. Lithological Unit 6 contains benthic fauna of Gyroidinoides neosoldanii, indicating deposition in a lower bathyal paleodepths. A single specimen of Amphistegina was also recovered, indicating minor downslope transport of shallow-water material (Strong et al., 1999), which is consistent with downlap reflectors on seismic reflection data (Figure 3.12).

A prominent lithological change from mudstone to limestone, is represented by a downhole change in the density log at $1096 \mathrm{~m}$ bsf (Figure 3.11). An increase in acoustic impedance in observed on seismic reflection data and supported by a $461 \mathrm{~ms}^{-1}$ increase in interval velocity (Figure 3.10); defining seismic reflection UB5.

\subsubsection{Lithological Unit 5 (1096-1285 m bsf)}

Lithological Unit 5 comprises $189 \mathrm{~m}$ of Oligocene limestone correlated to the Tikorangi Formation (Stagpoole, 2011). Based on carbonate grain-size, it ranges from mudstone to wackestone, with rare traces of glauconite, volcanic detritus and argillite (Milne and Quick, 1999). Benthic and planktic fauna of Cibicides karreriformis and Zeauvigerina parria, and dinoflagellate Deflandrea phosphoritica indicate the unit has a Duntroonian (Ld; late Oliogcene) to Kaiatan (Ak; late Eocene) age of 25-38 Ma (Strong et al., 1999). Lithological Unit 5 contains benthic fauna of Tritaxilina zealandica, Gyroidinoides neosoldanii and Cibicides collinsi suggesting deposition in lower bathyal paleodepths.

At $1131 \mathrm{~m}$ bsf, a sharp $\sim 0.6 \mathrm{~g} / \mathrm{cm}^{3}$ downhole increase in density represents a decrease in mud content within the limestone (Figure 3.10). This lithological change corresponds to a $524 \mathrm{~ms}^{-1}$ increase in interval velocity (Figure 3.10). At $1285 \mathrm{~m} \mathrm{bsf,} \mathrm{a} \sim 0.2 \mathrm{~g} / \mathrm{cm}^{3}$ decrease in density, $1101 \mathrm{~ms}^{-1}$ decrease in interval velocity, and increasing density neutron separation is consistent with a lithological change from limestone to marl. This results in a decrease in acoustic impedance (i.e. reverse polarity) that correlates with seismic reflection UB4. 


\subsubsection{Lithological Unit 4 (1285-1472 $\mathrm{m}$ bsf $)$}

Lithological Unit 4 comprises $187 \mathrm{~m}$ of limestone and calcareous claystone with occasional limestone stringers and red marl units (Milne and Quick, 1999), which are correlated to Tangaroa and Turi equivalents (Stagpoole, 2011). Between 1421-1472 m bsl the marl is firm and occasionally hard and corresponds to an increase in density. With increasing depth, calcareous content decreases and the lithology is essentially a massive claystone below 1472 m, correlated to the Turi Formation (Stagpoole, 2011). Planktic fauna Globigerapsis index, Pseudogloboquadrina primitiva, Gaudryina reliqua and Vulvulina espinosa indicate the unit has a Bortonian (Ab; late middle Eocene) to Heretaunhan (Dh; early to middle Eocene) age of 39-48 Ma (Figure 3.11). Lithological Unit 4 contains benthic fauna of Gyroidinoides neosoldanii Nuttallides truempyi and Tritaxilina zealandica, indicating deposition in lower bathyal paleodepths (Strong et al., 1999).

A relatively uniform sequence of marl is present between 1285 and $1472 \mathrm{~m}$ bsf (Figure 3.10). An increase in argillaceous material corresponds to a slight increase in density $(\sim 0.2$ $\left.\mathrm{g} / \mathrm{cm}^{3}\right)$ and interval velocity $\left(\sim 0.2 \mathrm{~g} / \mathrm{cm}^{3}\right)$ at $1442 \mathrm{~m}$ bsf (Milne and Quick, 1999), yields an increase in acoustic impedance and corresponds to seismic reflection UB3 (Figure 3.10). 

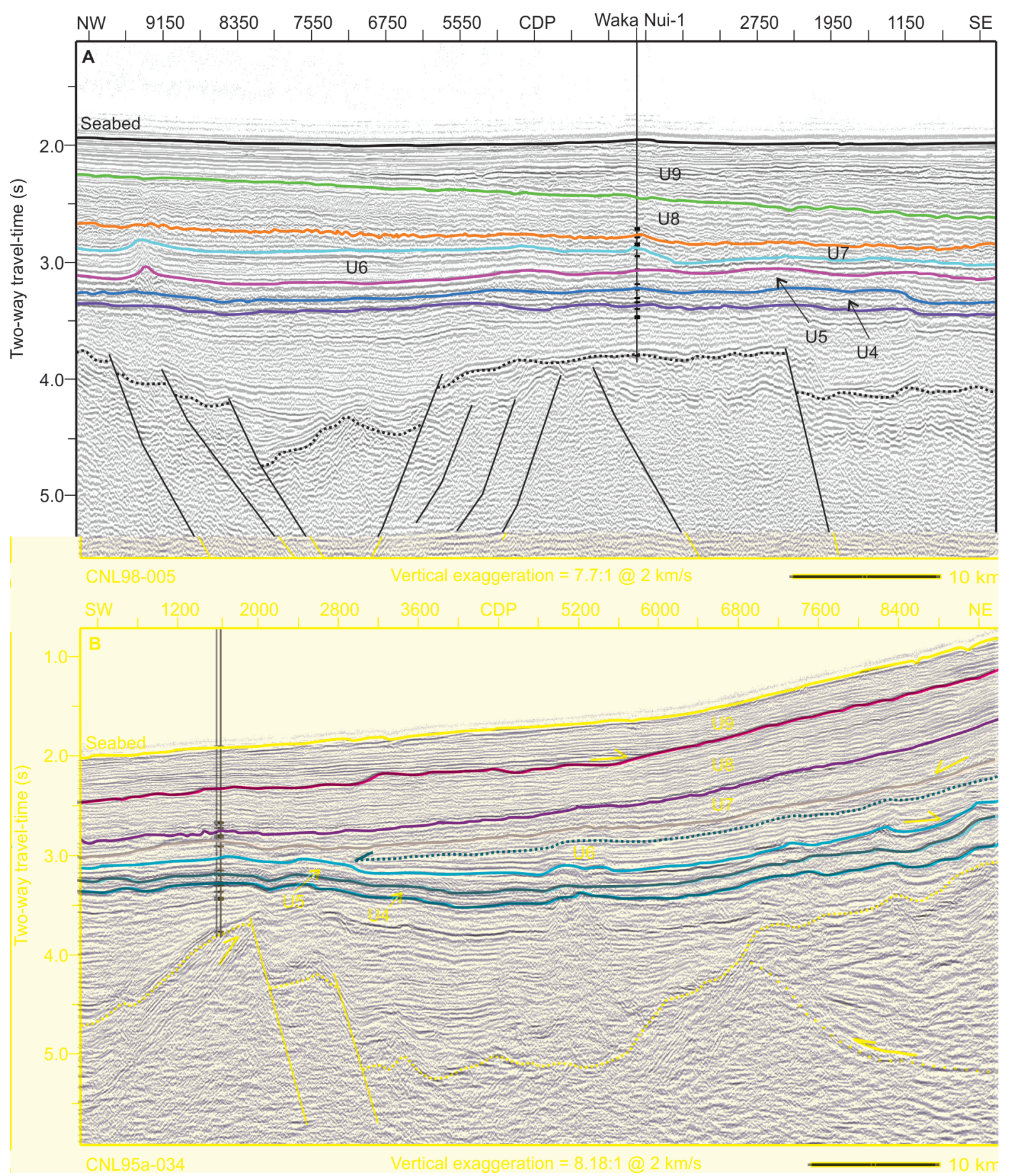

Figure 3.12: Seismic reflection lines (CNL98-005 and CNL95-034) showing Waka Nui-1 well ties to seismic data. (A) Seismic units are conformable and show no along-strike variation. (B) Seismic units 4 (U4) and 5 (U5) are condensed and conformable. U6, U8 and U9 onlap their respective basal unconformities, whereas U7 downlaps. Dashed black lines delineate high-amplitude Murihiku Terrane which are tilted, truncated and faulted in Waka Nui-1 and deformed by a low-angle thrust towards the northeast (after Bache et al. 2014a). Figure location is shown in Figure 3.2. 


\subsection{Synthesis of offshore rock samples}

Six lithostratigraphic units have been identified by analysing lithological and biostratigraphic data in the context of mapped seismic-stratigraphic units (Table 3.5; Figure 3.13).

Unit 4 comprises early to middle Eocene nannofossil chalk and limestone that are fractured and tilted as much as $15^{\circ}$ at Site U1508, and calcareous claystone with marl units at Waka Nui-1. Dredge samples of similar age (d6E, d8D, d53B and d69E) are bioclastic and micritic limestones. Abundant benthic faunal assemblages indicate a dominant middle bathyal paleodepth across all samples. Uppermost bathyal and possibly shelfal taxa were identified in dredge samples near West Norfolk Ridge. Shallow-water fauna are interpreted to represent the upper part of $\mathrm{U} 4$ and hence strata record progressive uplift and subsequent downslope transport during progressive deformation.

Unit 5 is stratigraphically variable between Reinga and Northland Basins. It comprises late Eocene clayey nannofossil chalk with cherty limestone that are fractured and tilted as much as $12^{\circ}$ at Site U1508, and late Eocene to late Oligocene mudstone-wackestone in Waka Nui-1. Benthic faunal asseblages and a high planktic:benthic ratio indicate a dominant middle bathyal paleodepth. At Site U1508, late Eocene taxa that are most common at lower neritic to bathyal and upper bathyal depths indicate a small amount of uplift, possibly on the order of a few hundred metres, and incoming downslope transport. This is consistent with reworked, inner-shelf Areoligera-Glaphyrocysta palynomorphs. Based on the oldest biostratigraphic age and lithology, dredge sample d19B is tied to U5 and indicates inner to middle shelf depths near southern Wanganella Ridge.

Unit 6 is stratigraphically variable between Reinga and Northland basins. It comprises late Oligocene foraminiferal ooze and chalk with clay silicate minerals and volcanic clasts at Site U1508. Dredge samples of a similar age comprise calcareous mudstone (d36D) and limestone (re7). A 6 Myr hiatus omits the early Oligocene sequence at Site U1508. Abundant benthic foraminfera indicate a dominant middle bathyal paleodepth across samples in Reinga Basin. Although, significant offshore transport from a nearby landmass are indicated by reworked palynological assemblages lacking pelagic components, a peak in shallow-water ostracod species and large amounts of terrestrial sporomorphs above the early Oligocene unconformity (34-28 Ma); and immediately below the early Miocene hiatus (e.g. UB6; 23$18 \mathrm{Ma})$. At Waka Nui-1, U6 comprises late Oligocene to early Miocene calcareous silitsone with interbedded sand and minor volcaniclastics. A 6 Myr intra-unit unconformity omits the late Oligocene-middle early Miocene. Benthic fauna indicate minor downslope reworking of shallow-water material into lower bathyal conditions in Northland Basin.

Unit 7 is stratigraphically variable between Reinga and Northland basins. It comprises 
early to middle Miocene foraminiferal ooze and chalk with clay, silicate minerals and volcanic clasts at Site U1508, and a dredge sample of similar age is bioclastic limestone (d75K). A 5 Myr hiatus omits the early Miocene sequence at Site U1508 (23-18 Ma). Palynological and benthic faunal assemblages at Site U1508 indicate a dominant middle to lower bathyal paleodepth, however, abundant middle shelf fauna were sampled on South Maria Ridge. At Waka Nui-1, U7 comprises middle to late Miocene interbedded siltstone, sandstone and minor volcaniclastics. Benthic fauna indicate minor downslope reworking of shallow-water material into lower bathyal conditions in Northland Basin.

Unit 8 comprises late Miocene clayey nannofossil ooze with ash layers at Site U1508 and calcareous silty marl with minor volcaniclastics in Waka Nui-1. A 1 Myr unconformity at Site U1508, and 2 Myr in Waka Nui-1, separates the unit from underlying material. Benthic fauna indicate a dominant lower bathyal paleodepth at borehole sites. Abundant pelagic palynomorphs indicate an open-ocean setting with high amounts of offshore transport in Reinga Basin.

Unit 9 comprises foraminiferal ooze with variable amounts of nannofossils and bioclasts. A 2 Myr unconformity has removed most of the Pliocene record from Site U1508. No returns were analysed above the late Miocene in Waka Nui-1. Benthic fauna indicate a dominant middle bathyal paleodepth, however some shelf- to upper bathyal-restricted benthic fauna are sporadically present.

Stratigraphic variability between lithological units reflects the diachronous nature of seismic units. This is inherent of the seismic-stratigraphic framework (e.g. Section 2.2) and indicates that tectonic events pertinent to deposition of these units is not experienced the same throughout the region. This also emphasises the importance of sampling within the basin, as ties from Reinga Basin to Waka Nui-1 may not accurately represent the basin history. 
Table 3.5: Summary of offshore rock samples in this study. Dredge sample ages refer to age range of samples correlating to the seismic unit.

\begin{tabular}{|c|c|c|c|}
\hline Rock Sample & Site U1508 & Waka Nui-1 & Dredge \\
\hline \multicolumn{4}{|c|}{ Seismic Unit 9} \\
\hline Age (Ma) & $5-0$ & $5-0$ & $\mathrm{~N} / \mathrm{A}$ \\
\hline Thickness (m) & 92.8 & 220 & $\mathrm{~N} / \mathrm{A}$ \\
\hline Lithology & $\begin{array}{l}\text { Foraminiferal ooze with nannofossils } \\
\text { and coarse-bioclasts }\end{array}$ & $\mathrm{N} / \mathrm{A}$ & $\mathrm{N} / \mathrm{A}$ \\
\hline \multicolumn{4}{|c|}{ Seismic Unit 8} \\
\hline Age (Ma) & $12-5$ & $8-5$ & $\mathrm{~N} / \mathrm{A}$ \\
\hline Thickness (m) & 116 & 511 & $\mathrm{~N} / \mathrm{A}$ \\
\hline Lithology & $\begin{array}{l}\text { Clayey nannofossil ooze with } \\
\text { foraminifera and rare ash }\end{array}$ & $\begin{array}{l}\text { Calcareous silty marl with minor } \\
\text { volcaniclastics } \\
\text { Seismic Unit } 7\end{array}$ & $\mathrm{~N} / \mathrm{A}$ \\
\hline Age (Ma) & $23-12$ & $16-8$ & $23-19$ \\
\hline Thickness (m) & 112.9 & 140 & $\mathrm{~N} / \mathrm{A}$ \\
\hline Lithology & $\begin{array}{l}\text { Foraminiferal ooze and chalk with clay, } \\
\text { silicate minerals and volcanic clasts }\end{array}$ & $\begin{array}{c}\text { Interbedded silt, sand and } \\
\text { volcaniclastics }\end{array}$ & Bioclastic limestone (d75k) \\
\hline \multicolumn{4}{|c|}{ Seismic Unit 6} \\
\hline Age (Ma) & $34-23$ & $25-16$ & $35-16$ \\
\hline Thickness (m) & 56.5 & 225 & $\mathrm{~N} / \mathrm{A}$ \\
\hline Lithology & $\begin{array}{l}\text { Foraminiferal ooze and chalk with clay, } \\
\text { silicate minerals and volcanic clasts }\end{array}$ & $\begin{array}{l}\text { Calcareous siltstone with interbedded } \\
\text { sand and volcaniclastics }\end{array}$ & $\begin{array}{l}\text { Bathyal limestone (re7), bioclastic } \\
\text { limestone with chert (d19B), and } \\
\text { calcareous mudstone (d36D) }\end{array}$ \\
\hline \multicolumn{4}{|c|}{ Seismic Unit 5} \\
\hline Age (Ma) & $39-34$ & $38-25$ & $42-35$ \\
\hline Thickness (m) & 107.7 & 189 & $\mathrm{~N} / \mathrm{A}$ \\
\hline Lithology & Clayey nannofossil chalk with cherty & Limestone (mudstone-to-wackestone) & Bioclastic limestone with chert (d19B) \\
\hline \multicolumn{4}{|c|}{ Seismic Unit 4} \\
\hline Age (Ma) & $48-39$ & $48-38$ & $56-42$ \\
\hline Thickness (m) & 199.2 & 187 & $\mathrm{NA}$ \\
\hline Lithology & $\begin{array}{l}\text { Nannofossil chalk and nannofossil } \\
\text { limestone }\end{array}$ & Calcareous claystone with marl & $\begin{array}{l}\text { Bioclastic }(\mathrm{d} 6 \mathrm{E}, \mathrm{d} 8 \mathrm{D}) \text { and micritic } \\
\quad(\mathrm{d} 53 \mathrm{~B}, \mathrm{~d} 69 \mathrm{E}) \text { limestones }\end{array}$ \\
\hline
\end{tabular}




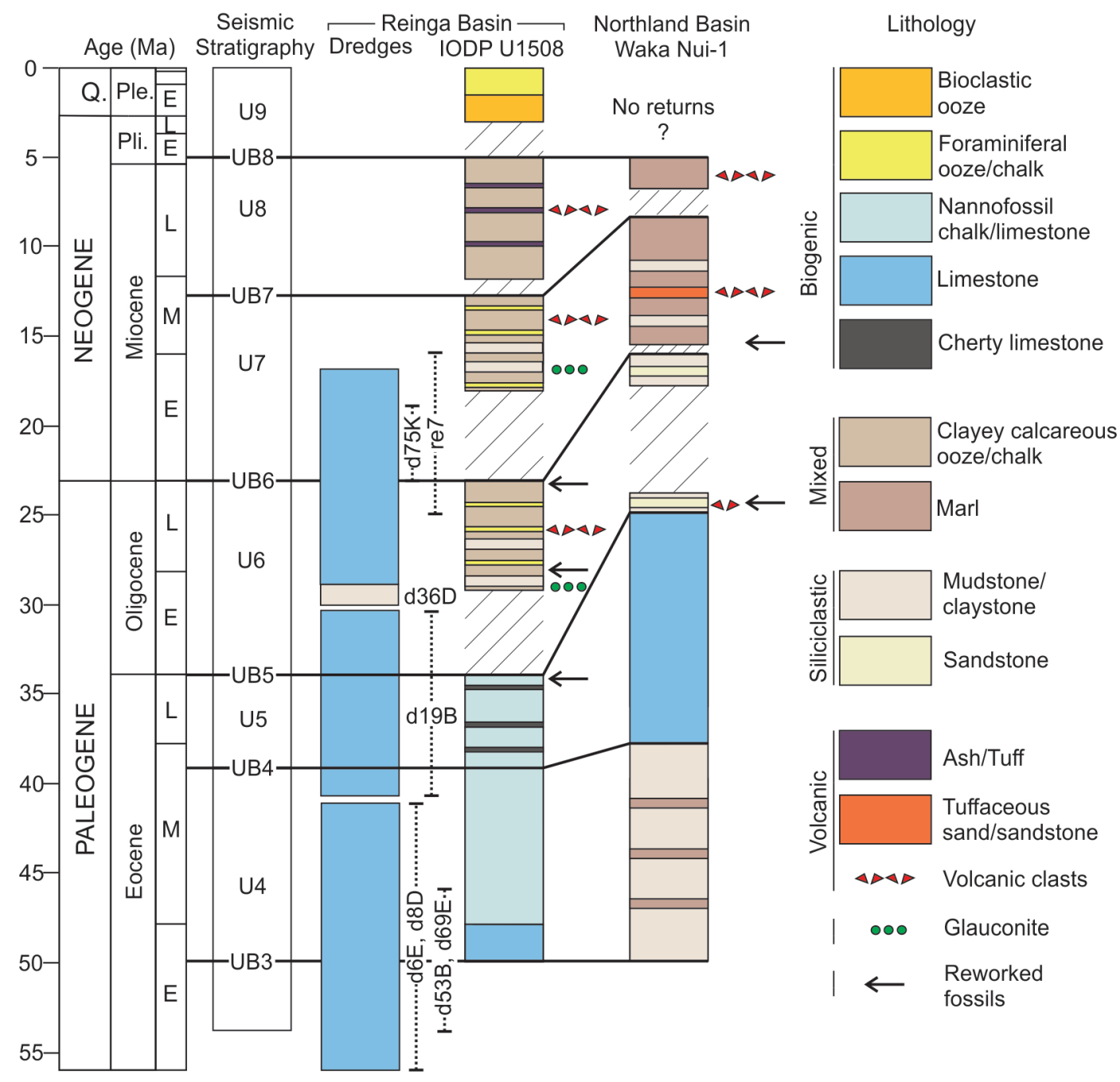

Figure 3.13: Stratigraphic correlation between boreholes and dredge samples across Reinga and Northland basins. Stratigraphic boundaries at boreholes are based on core descriptions and biostratigraphy and reassessment of existing data (Milne and Quick, 1999; Strong et al., 1999; Stagpoole, 2011; Sutherland et al., 2019a). Boundaries determined using dredge samples (Herzer et al., 1997; Browne et al., 2016) are based solely seismic-stratigraphic interpretations due to the high uncertainty in ages (dashed bars). Position of seismic units and their bounding horizons identified in this study are derived from two-way-time with depth, and age with depth relationships (Figures 3.7, $3.8,3.10$ and 3.11). Arrows indicate the position that reworked shallow-water taxa are sampled in the borehole. 
Rock Samples 


\section{Chapter 4}

\section{Basin History}

Age, lithology and paleoenvironment are inferred from dredged rock samples and IODP Site U1508 for seismic-stratigraphic units in Reinga Basin. This chapter outlines a revised middle Eocene to early Miocene basin history, and discusses differences to interpretations made before stratigraphic control was available.

\subsection{Late Cretaceous-Paleocene}

Late Cretaceous and Paleocene stratigraphy was not mapped in this study. However, it is important to consider these older sequences when discussing the evolution of Reinga Basin.

Strata of inferred Cretaceous age are most prevalent in southern Reinga Basin, where syn-rift deposition and termination against basement highs created by extensional faulting is observed (Herzer et al., 1997; Bache et al., 2012a,b). These localised basins prevent continuous ties to boreholes in Taranaki Basin, where syn-rift sequences have been constrained by boreholes (Strogen et al., 2017). Dredge samples of Turonian-Coniacian (94-90 Ma) age carbonaceous sandstone and mudstone, and Santonian (86-84 Ma) black marine shale (Herzer et al., 1999) show that shallow marine and terrestrial facies are present in Reinga Basin, and supports correlation with other New Zealand basins (Browne et al., 2016).

Based on seismic-stratigraphy, parallel and continuous Paleocene strata bury topographic highs created by Cretaceous extensional faulting (Bache et al., 2012a,b). Seismic-stratigraphic correlations can be made to Waka Nui-1, which sampled Paleocene strata, but ties are discontinuous (Bache et al., 2012a,b). Early Paleocene strata at Waka Nui-1 comprise an 80.5 $\mathrm{m}$ thick transgressive conglomerate and sandstone facies that is in turn overlain by $444 \mathrm{~m}$ of Turi Formation correlative bathyal siltstone and mudstone (Stagpoole, 2011). Flooding 
of transgressive facies containing shallow-water fauna (e.g. Textularia plummerae, 0-50 m), suggests the development of marine conditions during early Paleocene, and upper to middle bathyal by late Paleocene time (Baur et al., 2014). Tectonic subsidence calculations suggest $0.7 \mathrm{~km}$ of tectonic subsidence accrued during the Paleocene (70 $\mathrm{m} \mathrm{Myr}^{-1}$ ) (Baur et al., 2014). In addition, dredged sediment with Paleocene ages from Reinga Ridge comprise mudstones deposited in low-energy marine conditions far from land, based on dinoflagellates (Browne et al., 2016).

\subsection{Early to middle Eocene}

The early to middle Eocene succession in Reinga Basin correlates with Seismic Unit 4 (U4). Seismic stratigraphic ties to Site U1508 and Waka Nui-1 reveal a consistent age of 48-39 Ma for the unit between basins, based on age-depth models. UB3 was likely not sampled at Site U1508, and based on extrapolating sedimentation rates from the borehole could be $54 \mathrm{Ma}$ in Reinga Basin (e.g. Section 3.3.1). This is speculative, and a maximum age of $48 \mathrm{Ma}$ is adopted. Dredge samples give ages of 56-43 Ma for the unit but are tied directly to seismic data. Seismic Unit 4 is faulted and folded in northwest Reinga Basin. Strata onlap the basal unconformity UB3 near West Norfolk Ridge in western Reinga Basin, and are conformable in the rest of Reinga and Northland basins. U4 early to middle Eocene strata are syn-tectonic near West Norfolk Ridge, indicating deformation at the ridge pre-dates folding elsewhere.

Seismic Unit 4 contains a series of high amplitude continuous reflectors, consistent with regional pelagic carbonate deposition. The unit is correlated with nannofossil chalk and limestone at Site U1508 (Sutherland et al., 2019a), calcareous claystone with interbedded marl at Waka Nui-1 (Milne and Quick, 1999), and coarse bioclastic or micritic limestones where dredged. Micritic limestones are inferred to be broadly equivalent in terms of age and lithology to parts of the Amuri Limestone of eastern New Zealand (Browne et al., 2016). Parts of the Amuri Limestone are thought to act as a mechanically weak layer that functions as a decollement for fold-thrust belts in local fold systems in Marlborough (Van Dissen et al., 2005). Sedimentation rates derived from age-depth models at borehole sites (e.g. thickness per time interval in Table 3.5), combined with lithology, indicate pelagic deposition in Reinga Basin, and hemipelagic deposition in Northland Basin.

Abundant benthic fauna were recovered across borehole and dredge samples, and reveal a dominant middle bathyal paleodepth, however, there is evidence for shallow-water conditions proximal to Reinga Basin (Figure 4.1A). Reworked uppermost bathyal, and possibly shelfal, taxa were identified in dredge samples near West Norfolk Ridge (Browne et al., 2016). These dredge samples were collected near a wave ravinement surface identified on seismic reflection 

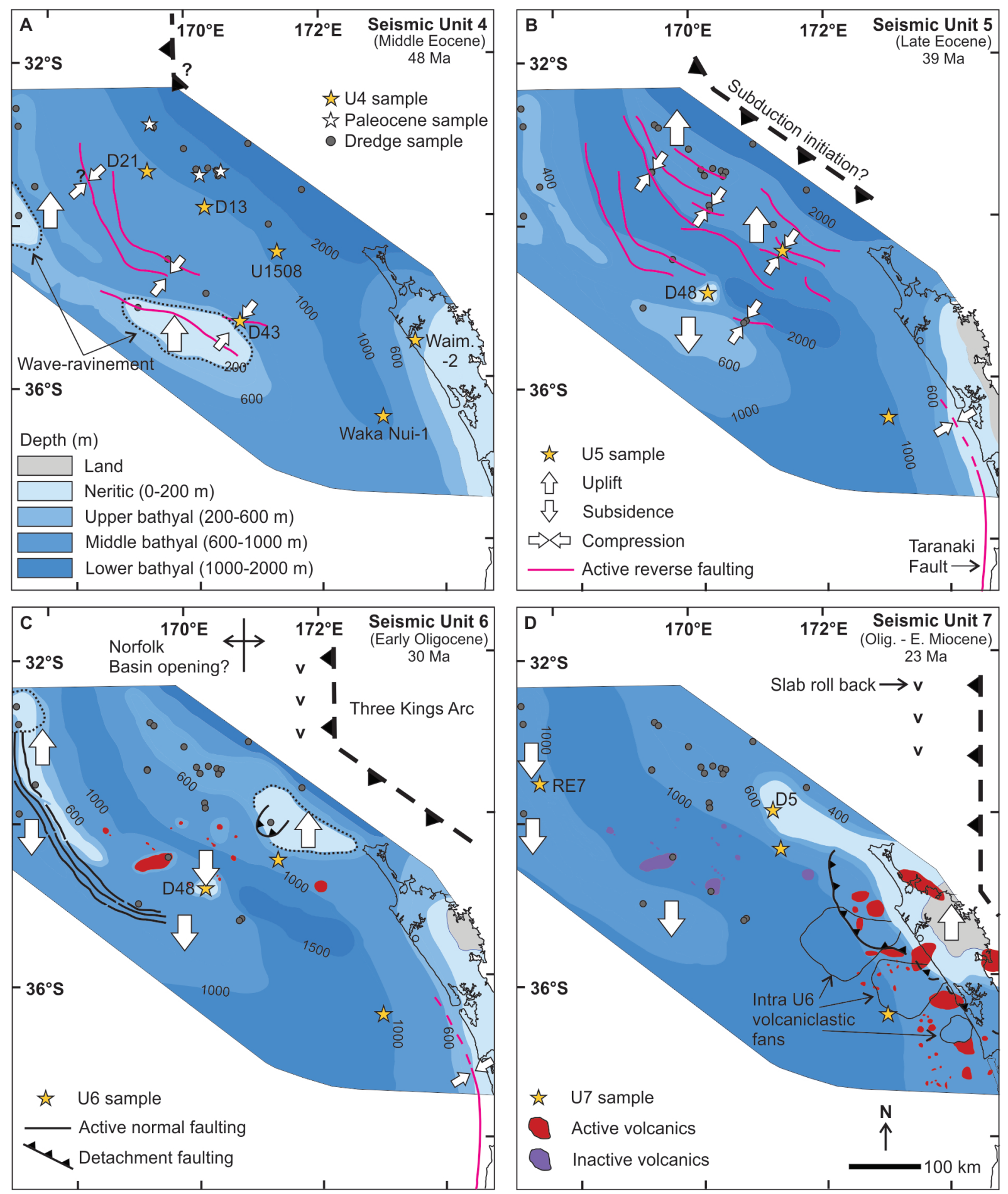

Figure 4.1: Paleogeography maps of northwest New Zealand based on seismic mapping, borehole and dredge constraints, and onshore geology (Hayward et al., 1989; Isaac et al., 1994). Dashed lines show areas of wave ravinement. (A) Early to middle Eocene (48 Ma) map showing compression and reverse faulting along western Reinga Basin. Samples indicate dominant middle bathyal water depths. (B) Late Eocene (39 Ma) map showing pervasive reverse faulting and compression, forming a depocentre in the centre of the basin. West Norfolk Ridge subsides and South Maria Ridge uplifts. (C) Early Oligocene (30 Ma) map showing normal faulting through Wanganella Ridge. South Maria Ridge is uplifted to shallow-water and the allochthon is emplaced. West Norfolk Ridge subsided to middle bathyal depths. Volcanism is inferred to initiate in Reinga Basin (34-28 Ma). (D) Late Oligocene to early Miocene (23 Ma). Northland Allochthon has been emplaced, and volcanism starts in Northland. South Maria Ridge subsides from middle shelf to middle bathyal depths from 23-19 Ma. Key information for bathymetry in A, deformation in B and C, and volcanics in D. 
data (Figure 4.2). Biostratigraphic and seismic interpretations are in agreement - folded strata that are inferred basin-wide to comprise middle bathyal carbonates, are truncated by a sea level-modulated erosion surface and reworked downslope with shelfal constituents to bathyal depths.

The stratigraphically oldest evidence for reverse faulting, folding and uplift is observed near southern West Norfolk Ridge (Figure 4.2). Folded U4 bioclastic limestone contains downslope transported fossils with ages of 56-43 Ma, but the fold is not eroded. This suggests folding occured after the ridge had subsided to sufficient depths to prevent erosion of the anticline. Therefore, there are two phases of folding: (1) before wave ravinement; and (2) after subsidence. Strata associated with the first phase are within U4, and the second within U5 (Figure 4.2). Benthic fauna at Site U1508 indicate a small amount of uplift on the order of a few hundred metres (e.g. from lower to middle bathyal) during the middle Eocene, but compression may be overprinted on a region-wide phase of subsidence (e.g. Section 5.2).

Reverse faults and folds with similar geometry are observed along strike of the western limit of Reinga Basin (Figure 4.1A). Near these areas of active faulting, compression creates accommodation space that is filled by downslope sediment transport, leading to deposits of U4 that are up to $3 \mathrm{~km}$ thick near Wanganella Ridge (e.g. Section 2.5).

U4 tectonostratigraphy slightly differs from previous interpretations. Deposition was inferred in bathyal conditions around the margin of West Norfolk Ridge, and abyssal conditions near eastern ridges of Reinga Basin (Bache et al., 2012a), where it marked the final deposit in a Late Cretaceous to late Eocene phase of passive subsidence and subsequent burial of extensional structures (Bache et al., 2012b). Dredge samples and boreholes affirm this interpretation. Early to middle Eocene shallow-water conditions, compression and reverse faulting, and subsequent erosion of West Norfolk Ridge were not inferred by Bache et al. $(2012 \mathrm{a}, \mathrm{b})$.

U4 is correlated by Stagpoole (2011) to the Turi Formation of Taranaki Basin in Waka Nui-1, where it is a dark-coloured marine mudstone deposited during a widespread phase of subsidence and known to onlap rift topography (King and Thrasher, 1996), thereby marking the onset of regional marine transgression. However, tectonic subsidence calculations for Waka Nui-1 and benthic fauna at Site U1508 indicate the region was in lower bathyal depths before U4 deposition (Baur et al., 2014; Sutherland et al., 2019a). Shallow-water sandstone and shelf to bathyal calcareous mudstone were deposited over northwestern Northland during the middle Eocene (Hayward et al., 1989). Sampled sediments indicate increasing carbonate content to the northwest. These lines of evidence suggest gradual deepening towards Reinga Basin in the early to middle Eocene. 

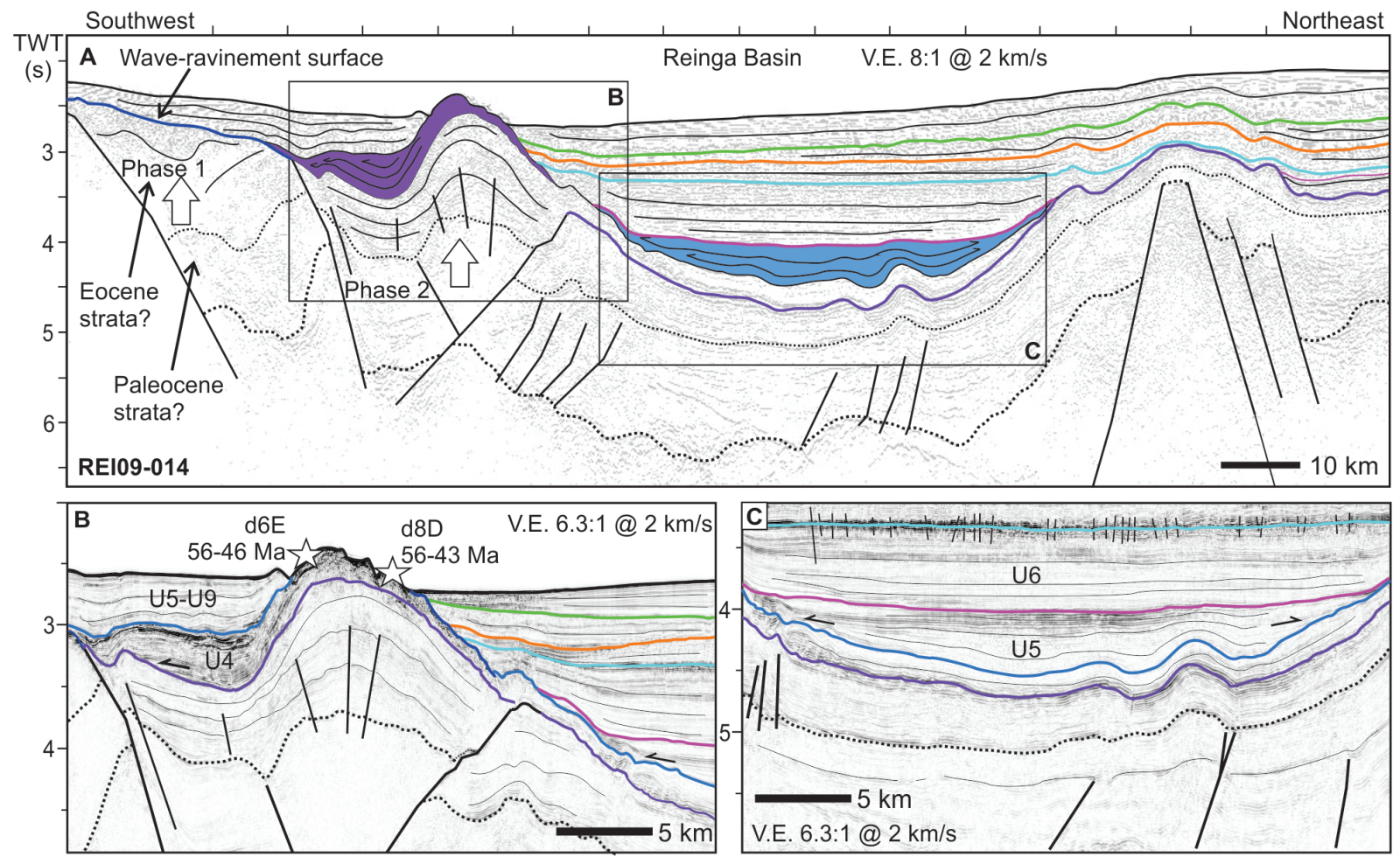

Figure 4.2: (A) Line drawing of seimsic reflection line REI09-014 across Reinga Basin showing two phases of compression. The first phase of folding leads to uplift of West Norfolk Ridge and subsequent truncation of inferred Eocene to Paleocene strata at 56-43 Ma. The second phase of folding occurs after subsidence to sufficient depths to prevent erosion of the fold at 39-34 Ma. Sediments deposited during the first phase are in U4 (purple), and the second phase in U5 (blue). (B) The early to middle Eocene age of phase 1 folding is recorded within U4. Bioclastic limestones contain fauna indicative of 150-1000 m paleodepths and date syn-tectonic deposition to 56-43 Ma. (C) Phase 2 of folding is recorded within U5. Basin-wide compression leads to development of a syncline in central Reinga Basin, and the adjacent anticline. U5 strata are dated at Site U1508 to 39-34 Ma. See Appendix B.3 for figure location.

\subsection{Late Eocene}

The late Eocene succession of Reinga Basin correlates with Seismic Unit 5 (U5). Seismic stratigraphic ties to Site U1508 reveal an age of 39-34 Ma. Strata comprise clayey nannofossil chalk and cherty limestone at Site U1508 (Sutherland et al., 2019a). Seismic Unit 5 onlaps faulted and folded U4 in central and northeastern Reinga Basin, and are conformable throughout the rest of the study area. Reflector geometry suggests U5 represents growth strata during convergent deformation that led to faulting and folding of U4 in the centre and along the northeastern margin of the basin (Figure 4.1B).

Late Eocene convergent deformation led to pervasive reverse faulting in northeastern Reinga Basin, which exposed early-middle Eocene U4 strata at the seabed. Dredge samples reveal the minimum age of folded $\mathrm{U} 4$ strata is $46 \mathrm{Ma}$ (Figure 4.3A and $\mathrm{B}$ ), but the onset 
of convergent deformation is dated at $39 \mathrm{Ma}$ at Site U1508 (Figure 4.3C). Deformation initiated in western Reinga Basin and is inferred to have migrated east towards South Maria Ridge during late Eocene time. Near areas of active reverse faulting, compression creates accommodation space that is filled by downslope sediment transport, leading to deposits of U5 that are up to $1200 \mathrm{~m}$ thick (e.g. Section 2.5).

Benthic faunal assemblages and a high planktic:benthic ratio indicate a dominant paleodepth of middle bathyal across Reinga and Northland basins (Figure 4.1B). Late Eocene taxa that are common at neritic to upper bathyal depths reveal downslope transport and a signal of shallow-water near Site U1508. This provides a nearby sediment source for filling accommodation space created in the centre of the basin during the folding event. Northern Reinga Basin is distal from any terrigenous sediment source, but based on sedimentation rates at Site U1508 (23 $\mathrm{m} \mathrm{Myr}^{-1}$ ) was a depocentre for pelagic sedimentation. The reason early to middle Eocene strata are still exposed at the seabed is likely due to deep-water currents.

Undeformed bioclastic limestones sampled above a wave ravinement surface on the southern scarp of Wanganella Ridge contain reworked shallow-shelf fauna of 43-38 Ma age (Figure 4.1B). This suggests that part of the western ridge was in neritic water conditions. It is difficult to tie this limestone to seismic-stratigraphy, but on the basis of age alone it can be correlated to $\mathrm{U} 5$, or the youngest part of U4. The late Eocene limestones are inferred to be an offshore equivalent of Mahurangi Limestones that outcrop onshore Northland (Browne et al., 2016), which are incorporated within basal shear zones of the Northland Allochthon, and correspond regionally to Haerenga and Waka supergroups and a widespread phase of marine transgression (Mortimer et al., 2014b).

Coal measures onshore Northland provide evidence for land during the Late Eocene (Hayward et al., 1989; Isaac et al., 1994). There is no evidence for late Eocene deformation to generate uplift of land in Northland, but U5 tectonics in Reinga Basin created topography that allowed deposition of marginal marine facies (Figure 4.1B).

There is no evidence at borehole sites for a late Eocene unconformity, indicating conformable deposition region-wide. The top of U5 (UB5) was correlated by Bache et al. (2012a,b) to the base of late Eocene to Oligocene Tikorangi Formation at Waka Nui-1 (Stagpoole, 2011). Bache et al. (2012a,b) suggest U5 must be younger than U4 based on their age of U4 (42-35 Ma), but based on seismic to well ties in this study (e.g. Section 3.5), U5 is correlated to the entire Tikorangi Formation and is 39-25 Ma at Waka Nui-1. 

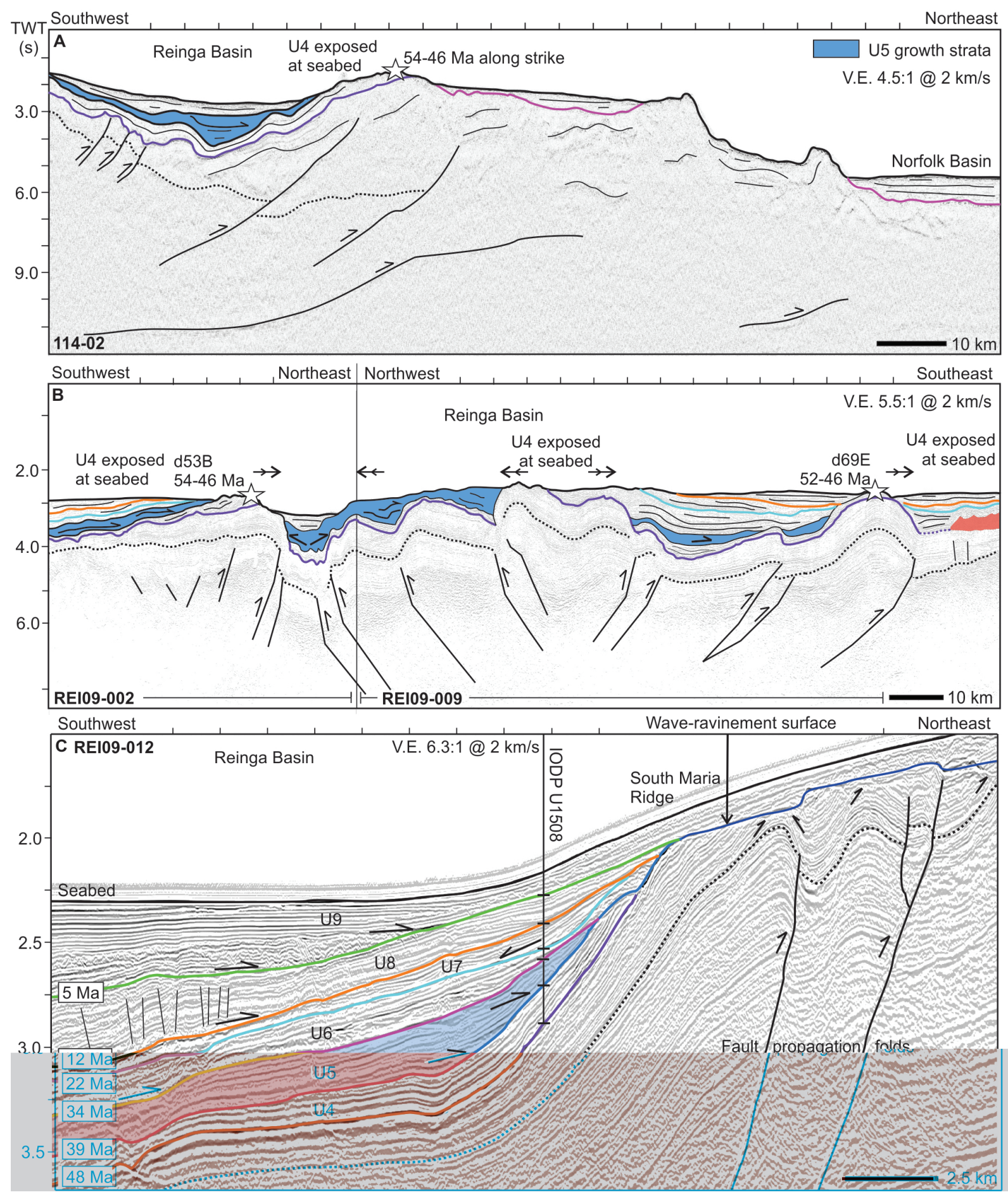

Figure 4.3: Interpreted seismic-reflection sections across select parts of Reinga Basin, locations from north to south: (A) southern Norfolk Ridge, (B) northern Reinga Basin, and (C) South Maria Ridge. (A) Northeast-verging folds are correlated along strike (to B). Southwest dipping low-angle faults accommodate folding and are proximal to an inferred southwest dipping nascent subduction zone. (B) Eocene compression is accommodated along large fault-propagation folds with opposing vergence directions (double-headed arrows). Dredged early to middle Eocene folded biomicritic limestones of U4 are exposed at the seabed and constrain the age of deformation in northern Reinga Basin. (C) Compression is accommodated by fault-propagation folds under South Maria Ridge. Deformed nannofossil chalk and cherty limestone of U5 are sampled at Site U1508 and constrain this phase of deformation to 39-34 Ma. See Appendix B.3 for figure locations. 


\subsection{Oligocene}

The Oligocene succession correlates with Seismic Unit 6 (U6) in Reinga Basin. Seismic stratigraphic ties to Site U1508 reveal a 34-23 Ma age for the unit. The early Oligocene section is represented by a 6 Myr hiatus. Sampled sediments comprise foraminiferal ooze and chalk with clay, silicate minerals and volcanic clasts, and are of late Oligocene age (28-23 Ma). U6 contains fanning and onlapping reflectors that record progressive folding, uplift, erosion and volcanic input at the basin margin (Figure 4.1C).

Reworked faunal assemblages at Site U1508 provide the first evidence for shallow-water conditions during the Oligocene near Reinga Basin. Late Oligocene palynological assemblages and ostracods, indicative of sediment transport from a nearby landmass, are located above early Oligocene, and below late Oligocene to early Miocene hiatuses. The large inferred changes in relative sea level are related to regional Late Eocene to Oligocene uplift. Sediments are sampled near a wave ravinement surface that truncates folded Cretaceous to Eocene strata beneath South Maria Ridge, suggesting erosion led to downslope transport of shallow-water taxa to bathyal depths (Figure 4.3C).

Despite a hiatus at Site U1508, early Oligocene deposition occurred in a $\sim 5 \mathrm{~km}$ wide syncline perpendicular to South Maria Ridge created during Eocene compression (Figure 4.4). Assuming a homogeneous background sedimentation rate, a number of mechanisms may be involved to prevent sediments from accumulating on the slope of South Maria Ridge: (1) erosion, (2) currents, or (3) the basin slope causing gravity sliding towards Reinga Basin. Most sedimentary basins around New Zealand record an unconformity characterised by the absence of late Eocene and/or early Oligocene strata - manifest as the Marshall Unconformity (Carter, 1985). The unconformity is linked to Tasman Gateway opening, causing a huge change in ocean temperature and currents (Carter et al., 1996; Fulthorpe et al., 1996; King et al., 1999). It is likely that Eocene to early Oligocene uplift and erosion downslope led to the hiatus near South Maria Ridge.

Progressive Eocene to Oligocene uplift led to emplacement of South Maria Allochthon along South Maria Ridge (Figure 4.1C, 4.4B). Downlapping U6 reflectors are interpreted as sediment progradation from the front of the allochthon. The downlap surface (UB5) correlates with downslope transport and reworked shallow-water fossils at Site U1508 that led to the early Oligocene hiatus. Evidence for downslope transport associated with allochthon emplacement is tied along strike to Site U1508 and date emplacement at 34-28 Ma. The gradient of South Maria Ridge steepens southward, but the allochthon is only imaged on one seismic line, restricting the geographic extent, and hence the inferred direction of emplacement is from the northeast. 


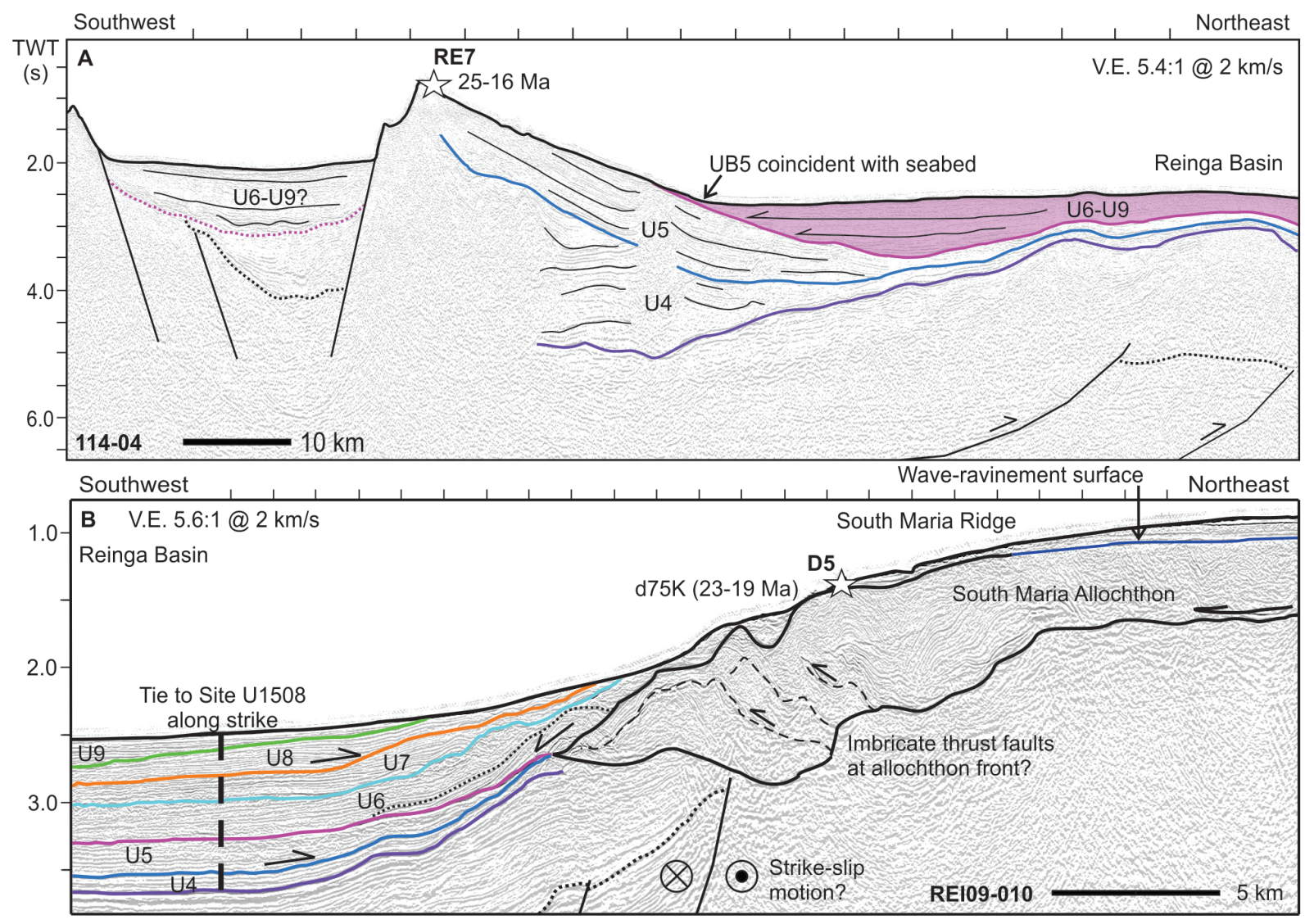

Figure 4.4: Interpreted seismic-reflection sections across select parts of Reinga Basin, locations from north to south: (A) Wanganella Ridge and (B) across South Maria Ridge. (A) Tilting of Seismic Unit 5 and onlap termination of U6-U9 reflectors indicate uplift of Wanganella Ridge between the deposition of these two units. UB5 is interpreted to outcrop at the seabed and can be tied over $350 \mathrm{~km}$ to Site U1508, which dates uplift of the ridge at 34-28 Ma. (B) Seismic Unit 6 reflectors downlap UB5 in front of the allochthon (dashed lines). Ties to Site U1508 along strike date the emplacement at 34-28 Ma. Early Miocene micritic limestone containing middle-shelf fauna was sampled above the allochthon and indicates subsidence to middle bathyal depths from 23-19 Ma. See Appendix B.3 for figure locations.

As South Maria Ridge uplifted, West Norfolk Ridge subsided (Figure 4.1C). Undeformed calcareous mudstone dated at 30-27 Ma was dredged above a wave ravinement surface on northern West Norfolk Ridge (e.g. 3.2.4). Benthic fauna from dredge samples indicate a middle bathyal paleodepth. Contrary to other dredge samples near wave ravinement surfaces, no shallow-water fossils were sampled, indicating a significant hiatus between formation of the wave ravinement surface and deposition of the sedimentary cover. Therefore, subsidence from wave-base to middle bathyal water depths had occurred by 30-27 Ma at northern West Norfolk Ridge.

The end of reverse faulting is determined from relationships to undeformed sediment. Shallow-water bioclastic limestones sampled above a wave ravinement surface on southern Wanganella Ridge mark the onset of subsidence to present-day lower bathyal depths at 36-30 Ma. Late Oligocene foraminiferal ooze and chalk at Site U1508 are comparatively less de- 
formed and are not fractured in cores compared to U4 and U5, which indicates that folding pre-dates the early Oligocene and deposition occurred after allochthon emplacement (34-28 Ma). West Norfolk Ridge subsided during the early Oligocene, and hence confirms compressional deformation had ceased in Reinga Basin.

The stratigraphic configuration of Wanganella Ridge suggests topography was created by extensional deformation rather than convergent deformation (Figure 4.4). Normal faults are observed through the axis of West Norfolk Ridge and cross-cut older folds created during Eocene compression (Figures 4.1C and 4.2A). Wanganella Ridge partly comprises U5, which contains parallel reflectors, indicating a time devoid of active faulting in this location. U6 and younger strata are deposited unconformably against the ridge, which suggests normal faulting and apparent uplift of Wanganella Ridge in the early Oligocene (34-28 Ma) based on stratigraphic ties to Site U1508. Dredged bathyal limestone from the ridge suggests it was in $>600 \mathrm{~m}$ water depths by $25 \mathrm{Ma}$ (Herzer et al., 1997). Previous interpretations have attributed Wanganella Ridge topography to differential uplift along the Vening-Meinesz Fracture Zone (Herzer et al., 1997; Mortimer et al., 2007; Herzer et al., 2009) and/or contraction related to development of Hikurangi-Northland subduction farther south during the early Miocene (Herzer et al., 1997; Bache et al., 2012a,b). However, it is suggested that normal faulting created topography of Wanganella Ridge during the early Oligocene (34-28 Ma), which is consistent with extension farther north along Norfolk Ridge (Sdrolias et al., 2004; DiCaprio et al., 2009), and subsidence of adjacent West Norfolk Ridge (Figure 4.1C).

Direct stratigraphic ties from a nearby volcano to Site U1508 provide evidence for the onset of volcanism in Reinga Basin (Figure 4.4). Volcanic clasts are described as silicate minerals (quartz and plagioclase) and lithic grains (clinoptilolite zeolite) at depths of 260$250 \mathrm{~m}$ bsf (Sutherland et al., 2019a). Correlating the position of volcanic clasts in the borehole to the age-depth model at Site U1508 suggests onset of volcanism at c. 25 Ma. However, due to the early Oligocene unconformity at Site U1508, the onset of volcanism could be earlier. The top of UB5 coincides with the flank of the volcano and is tied to the 6 Myr hiatus at Site U1508 (Figure 4.5A). Strata younger than UB5 onlap the volcano, suggesting volcanism started during the hiatus at Site U1508 at 34-28 Ma. Timing of early Oligocene volcanism is consistent with Three Kings Ridge volcanism farther north (Figure 4.1C).

Previous interpretations suggest that flanks of Reinga Basin were uplifted and sub-aerially exposed during the late Eocene and were eroded until late Oligocene peak uplift, leading to extensive shallow-marine deposition of U6 into sub-basins (Bache et al., 2012a,b, 2014b). Based on revised seismic-stratigraphic mapping and ties to sampled sediment, only South Maria Ridge was eroded in shallow-water conditions during this time (Figure 4.1C). Oligocene sedimentation is dominantly pelagic, based on sedimentation rates and borehole lithology at Site U1508 (9 $\left.\mathrm{m} \mathrm{Myr}^{-1}\right)$ and Waka Nui-1 $\left(13 \mathrm{~m} \mathrm{Myr}^{-1}\right)$. This is consistent with bathyal 
marl and shelfal limestone that are inferred to have accumulated onshore Northland during this time (Hayward et al., 1989).

U6 is diachronous between Reinga and Northland basins (e.g. Section 3.5). It is correlated to Taimana and Manganui formations at Waka Nui-1 and dated at 26-16 Ma. U6 has a 34-23 Ma age at Site U1508 and reflects a phase of tectonics that starts 7-9 Myr earlier compared to Northland, which is consistent with older volcanism (Figure 4.1C).

\subsection{Early to middle Miocene}

Seismic Unit 7 (U7) in Reinga Basin ties to Site U1508 where it is 23-12 Ma foraminiferal ooze and chalk with clay, silicate minerals and volcanic clasts. U7 contains downlapping reflectors that record subsidence and volcanic input near South Maria Ridge (Figure 4.3C).

A strong shallow-water ostracod signal was found below the 5 Myr late Oligocene to early Miocene hiatus (UB6) at Site U1508. This hiatus separates coarse-grained foraminiferal ooze and glauconite above from nannofossil chalk with foraminifers below at $321 \mathrm{~m}$ bsf (Sutherland et al., 2019a). Glauconite forms in a relatively large water depth range, from as shallow as below wave base to the upper slope $(\sim 0-500 \mathrm{~m})$, requiring low to negative sedimentation rates (McRae, 1972; Odin and Matter, 1981). Benthic fauna at Site U108 indicate a middle bathyal paleodepth, but it is likely to be at the upper end of the range because glauconite does not form in colder, deeper water. This suggests that U7 represents regression (i.e. relative sea level drop) and active erosion downslope that led to the hiatus.

Although Site U1508 was in middle bathyal depths, shallow-water conditions likely persisted along South Maria Ridge during late Oligocene to Miocene (Figure 4.1D). Undeformed bioclastic limestone dated at 23-19 Ma was dredged above the wave-ravined South Maria Allochthon and contains mid-shelf fauna. Limestones also contain lower bathyal fauna, interpreted to have been reworked from the allochthon, which is inferred to comprise bathyal sediment based on older stratigraphy. These lines of evidence suggest that South Maria Ridge underwent a phase of subsidence from middle shelf to middle bathyal (present-day) depths from 23-19 Ma. Subsidence of South Maria Ridge is the final tectonic phase in Reinga Basin.

Deformation migrated southeast to Northland Basin, culminating in Northland Allochthon emplacement. The base of the allochthon coincides with UB5, which is dated at $25 \mathrm{Ma}$ at Waka Nui-1. The timing of allochthon emplacement is consistent with onshore stratigraphic observations. The youngest pre-emplacement strata onshore are biostratigraphically dated as $30 \mathrm{Ma}$ at Waimamaku-2 (Hornibrook et al., 1976), but are $23 \mathrm{Ma}$ in eastern Northland (Brook and Hayward, 1989; Rait, 2000). Oldest overlying strata are dated at 20 Ma (Carter, 
1971; Hornibrook et al., 1976; Ballance and Spörli, 1979). Regardless, emplacement ages are notably younger than those derived from seismic-to-well ties for South Maria Allochthon in Reinga Basin. Fauna within lowest Waitemata Group syn-tectonic sediments indicate shallow-water conditions, followed by subsidence around the time the allochthon is inferred to have been emplaced in the early Miocene (Hayward, 1993; Spörli and Rowland, 2007).

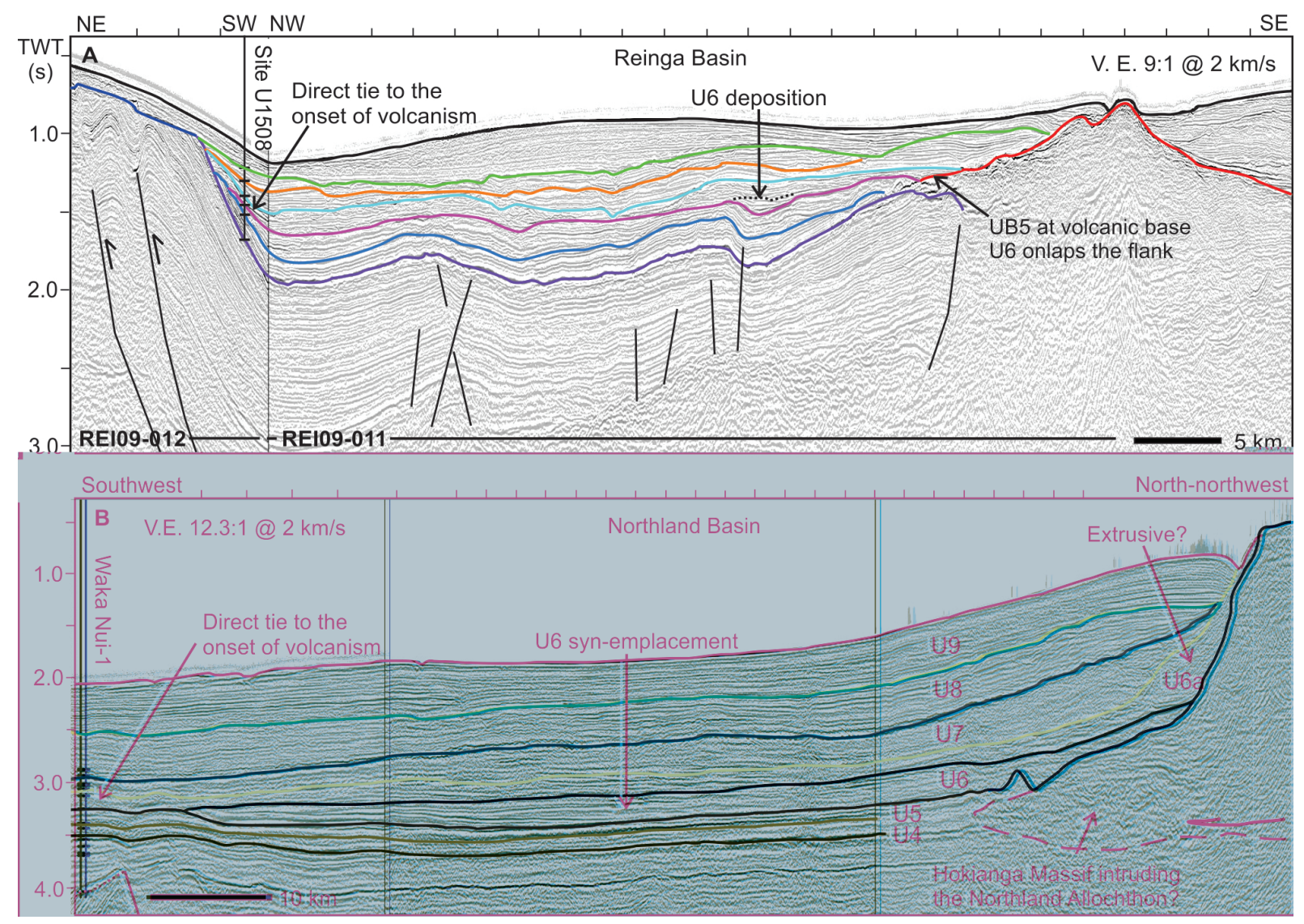

Figure 4.5: Interpreted seismic-reflection sections across Reinga and Northland basins showing stratigraphic ties of volcanism to boreholes. (A) UB5 coincides with the base of the volcanic edifice and is represented by a hiatus and dated at Site U1508 to 34-28 Ma. Deposition in accommodation space created by localised folding suggests the hiatus was only prevalent along the slope of South Maria Ridge. The dashed black line indicates when deposition of U6 strata becomes contemporaneous with deposition on the slope. Strata above this line onlap the volcano, suggesting volcanism started during the hiatus at Site U1508. (B) The base of the volcanic edifice similarly coincides with UB5 and is dated at $25 \mathrm{Ma}$ in the Waka Nui-1 borehole. U6 strata downlap UB5 and are interpreted as syn-emplacement deposits. U6a comprises potentially extrusive material based on seismic character. See Appendix B.3 for figure locations.

Direct stratigraphic ties to Waka Nui-1 reveal that volcanic edifices are coeval with UB5 in Northland Basin (Figure 4.5B). First evidence for volcanic activity is recorded at $1096 \mathrm{~m}$ bsf in the borehole (Milne and Quick, 1999). Correlation to the age-depth model constructed for Waka Nui-1 suggests the onset of arc volcanism in Northland Basin was c. 25 Ma. This is in agreement with the oldest volcaniclastic deposits exposed onshore that have stratigraphic ages of $23 \mathrm{Ma}$, and inferred to be derived from eruptive centres offshore (Hayward, 1993; King, 
2000b). Geochemical analysis indicates arc volcanism was widespread and established by 23 Ma (Hayward et al., 2001). Although there is no apparent eruptive trend, most Northland arc volcanic activity occurred in the early Miocene (Herzer, 1995). Volcanism lasted until c. 11 Ma, and younger volcanic edifices intrude the Northland Allochthon (Figure 4.5) (Hayward, 1993; Hayward et al., 2001; Herzer, 1995).

Deposition of volcaniclastic fans occurs in three areas where sub-marine volcanic edifices are observed (Figure 4.1D). Active volcanism and Northland allochthon emplacement was approximately synchronous with uplift of Northland Peninsula, and resulted in prolific sediment sources (Hayward et al., 1989; Uruski et al., 2004). Sedimentation rates from Waka Nui-1 (89 $\mathrm{m} \mathrm{Myr}^{-1}$ ) indicate that Northland Basin was receiving significantly more sediment than Reinga Basin (23 m Myr ${ }^{-1}$ ). The 1000-1200 m thick Oligocene to early Miocene (U6) succession in southern Reinga and Northland basins fills accommodation space created by late Eocene compression (e.g. Section 2.5). Deposition of these units marks the final phase of tectonic activity before Hikurangi-Northland subduction rolled back (Stern et al., 2006; Giba et al., 2010). Younger sediments in U8 and U9 are pelagic oozes and marls at borehole sites, indicative of tectonic quiescence from the middle Miocene. 


\section{Chapter 5}

\section{Discussion and conclusions}

\subsection{Timing and style of deformation}

Seismic ties to locations of sampled sediment provide constraints on the timing and style of deformation throughout Reinga Basin. The onset of uplift and folding was 56-43 Ma near southern West Norfolk Ridge, but strata with age 54-46 Ma are also deformed in northern Reinga Basin. Deformation propagated eastward near South Maria Ridge at 39-34 Ma and widespread convergence is accommodated along early to middle Eocene faults. The predominant southwest dip of thrust faults and northeast vergence of folds in northern Reinga Basin suggests any putative subduction zone dipped towards the southwest. Ongoing Eocene to Oligocene compression led to thin-skinned deformation and emplacement of South Maria Allochthon at 34-28 Ma. Wanganella Ridge topography was created in the early Oligocene (34-28 Ma) by normal faulting that extends through the axis of West Norfolk Ridge and marks the final phase of deformation in Reinga Basin.

Major tectonic phases started in New Caledonia during the Eocene. Deposition of early Eocene (56-48 Ma) turbidites onto bathyal Late Cretaceous and Paleocene (84-56 Ma) sedimentary rocks is the first signal for a new phase of tectonic activity in New Caledonia (Maurizot, 2011). Deformation, exhumation, and emplacement of ultramafic, mafic, and sedimentary allochthons occurred in New Caledonia during the middle and late Eocene (Aitchison et al., 1995; Cluzel et al., 2001), and was largely complete by 34 Ma (Baldwin et al., 2007). Obduction marks the end of convergence near New Caledonia, and lithospheric extension dominates the tectonic regime after $34 \mathrm{Ma}$ (DiCaprio et al., 2009). 


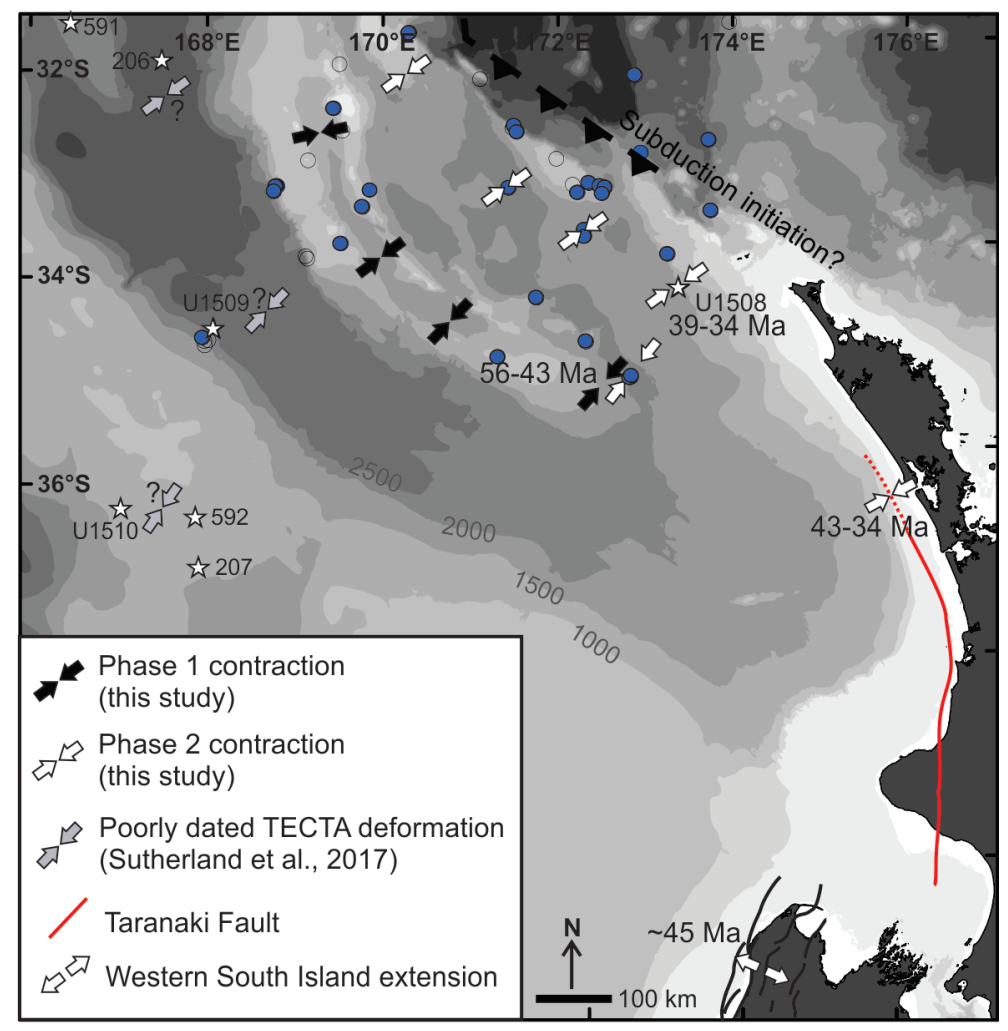

Figure 5.1: Two phases of compression events are identified in Reinga Basin. Phase 1 (black facing arrows) is manifest by folding along West Norfolk Ridge and is inferred to occur during the early to middle Eocene (56-43 Ma), based on dredged sediment from southern West Norfolk Ridge. Phase 2 (white arrows) is manifest by folding along the eastern margin of Reinga Basin. Ties to Site U1508 provide a late Eocene (39-34 Ma) age of deformation. The first phase is broadly synchronous with TECTA deformation (grey arrows) (Sutherland et al., 2017). The second phase is broadly synchronous with reverse fault motion on the Taranaki Fault (43-34 Ma) (Stagpoole and Nicol, 2008) and extension in western South Island ( 45 Ma) (Kamp, 1986; King, 2000a).

Eocene deformation is also observed in northern Zealandia (Figure 5.1). Folded Paleocene (65-61 Ma) mudstone dredged from southern New Caledonia Trough indicates that deformation took place in early or middle Eocene time (Browne et al., 2016). Syn-tectonic deformation on southern Lord Howe Rise is tied to DSDP Site 207 and Site 592 and dated at 56-37 Ma (Sutherland et al., 2017).

Eocene reverse fault motion is observed along the length of the Taranaki Fault (Stagpoole and Nicol, 2008). Deformation is inferred to commence at the northern end of the fault around 43-40 Ma, but continued until $34 \mathrm{Ma}$ (i.e. when New Caledonia obduction ceased) (Figure 5.1). Taranaki Fault displacement has previously been interpreted as retro-arc and associated with subduction of the Pacific plate beneath Australian Plate (Holt and Stern, 1994).

Rifting of Campbell and Challenger plateaus occurs to the south of New Zealand around 45 Ma. Based on stratigraphic evidence (Carter and Norris, 1976; Kamp, 1986; King, 2000a), and magnetic anomalies (Sutherland, 1995), rifting led to the inception of the Australia- 
Pacific plate boundary at the location of the Alpine Fault. This followed a period of tectonic quiescence during Tasman Sea speading (Gaina et al., 1998; Sutherland, 1999). Rifting propagated northwards from western Southland to Taranaki (King, 2000a).

A late Eocene onset of compression was initially inferred for Reinga Basin (Bache et al., 2012a,b). Borehole and dredge age constraints in this study reveal two phases of Eocene deformation. Folding along the West Norfolk Ridge margin is the initial phase of deformation and is dated at 56-43 Ma (Figure 5.1). This event is broadly synchronous with cessation of Tasman Sea spreading (Gaina et al., 1998); timing of deformation in New Caledonia, New Caledonia Trough and Lord Howe Rise (Sutherland et al., 2017); and occurs before other plate boundary related events (King, 2000a). Folding along South Maria Ridge is the second phase of deformation and is dated at 39-34 Ma. Convergent deformation during this time is closely related to timing of reverse movement on the Taranaki Fault (Stagpoole and Nicol, 2008), extension on the West Coast of the South Island (Kamp, 1986; King, 2000a) and New Caledonia allochthon obduction.

A middle Miocene deformation event was also inferred for Reinga Basin (Herzer et al., 1997; Bache et al., 2012a,b). This phase was linked to widely recognised deformation associated with Alpine Fault development through New Zealand (King, 2000a), and was postulated to invoke uplift of Wanganella Ridge. However, borehole and dredge age constraints reveal earlier Oligocene deformation and apparent uplift by normal faulting during subsidence. Extensional faulting through West Norfolk Ridge and Wanganella Ridge at 34-28 Ma is consistent with back-arc opening of Norfolk Basin (Sdrolias et al., 2004), and the end of convergent tectonics in New Caledonia (DiCaprio et al., 2009).

Following a phase of thick-skinned deformation, basin deformation is manifest by thinskinned tectonics. Late Eocene to Oligocene uplift of South Maria Ridge leads to emplacement of South Maria Allochthon. The allochthon appears to occur immediately during the early Oligocene hiatus, which determines the cessation of folding during the late Oligocene (34-28 Ma). Allochthon emplacement on South Maria Ridge is at least 4-8 Myr earlier than Northland Allochthon emplacement in Northland (30-20 Ma). There are a number of competing mechanisms for the emplacement of Northland Allochthon: (1) thin-skinned wedge driven by gravity sliding (Ballance and Spörli, 1979; Brook et al., 1988); (2) obduction from nucleation or margin approach of a northeast dipping subduction zone (Malpas et al., 1992; Herzer, 1995; Whattam et al., 2005; Schellart, 2007); or (3) crustal delamination associated with a west-dipping subduction zone (Mortimer et al., 1998, 2007; King, 2000b; Herzer et al., 2000; Bradshaw, 2004). It is outside the scope of this project to suggest a new regional tectonic model. Emplacement of the Northland Allochthon represents the last phase of plate boundary deformation along the northwest New Zealand. 


\subsection{Paleogeography and vertical tectonic motions}

The only practical way of measuring the elevation of crust through time is against a sea-level reference frame. Flat wave ravinement surfaces with regional consistency were mapped across ridges of Reinga Basin. These erosion surfaces are identified from truncations on multichannel seismic data and were depth converted. Shallow-water fossils encountered within sampled sediments at the Site U1508 borehole and dredge sites provide verification of the shallowwater origin and hence quantifiable estimates of Cenozoic vertical motions were calculated for their subsequent subsidence (Figure 5.2).

Fauna in bioclastic limestones near southern West Norfolk Ridge provide evidence for nearby shallow water conditions during the early Eocene (Browne et al., 2016). The shallowestwater fauna indicate $\sim 150 \mathrm{~m}$ paleodepth, but wave ravinement is invoked to require shallow depths of $<30 \mathrm{~m}$. Depth conversion of the wave ravinement surface indicates a present-day depth of 1.5-3.5 km (Figure 5.2). On this basis, a first-order approximation can be made that $>3000 \mathrm{~m}$ of subsidence has occurred since 56-43 Ma. In addition, at a dredge site on southern West Norfolk Ridge, exposed strata with maximum 400-1000 m paleodepths are now in 1783-1838 m water depth (Bache et al., 2014c), indicating the dredge site has undergone a minimum $\sim 800-1400 \mathrm{~m}$ subsidence.

Two wave ravinement surfaces are identified along northern West Norfolk Ridge (Figure 5.2 ). The deeper surface is continuous with the erosion surface on southern West Norfolk Ridge (e.g. Figure 5.3A). Sediments sampled above this surface are of Oligocene (30-27 Ma) age and contain middle bathyal fauna (Browne et al., 2016), indicating $\sim 1000 \mathrm{~m}$ of subsidence by $30 \mathrm{Ma}$, and a total $\sim 1500 \mathrm{~m}$ based on present-day depth of the erosion surface (Figure 5.3B). The shallower surface erodes the northern part of Wanganella Ridge and can be tied over a distance of $400 \mathrm{~km}$ to Site U1508, where the surface is tentatively linked to the early Oligocene UB5 unconformity. There is no sediment overlying the erosion surface, therefore the amount of subsidence is determined by present-day water depths to be $\sim 400$ $\mathrm{m}$. Sediments sampled from Wanganella Ridge indicate that the southern part of the ridge was at middle bathyal depths by 25-16 Ma (Figure 5.3C).

Fauna in foraminiferal ooze and chalk near South Maria Ridge provide evidence for shallow-water conditions during the late Oligocene (Sutherland et al., 2019a). Reworked shallow-water fauna in late Oligocene sediments at Site U1508 indicate uplift of South Maria Ridge from lower bathyal depths in the middle Eocene to neritic depths sufficient for wave ravinement during the late Oligocene (Figure 5.3A). Sampled bioclastic limestone along strike to the northwest contains middle shelf fauna and indicates shallow-water conditions at South Maria Ridge persisted until 23-19 Ma. Present-day depth of the wave ravinement surface is 1000-2000 m, suggesting that the ridge has undergone 900-1900 m of subsidence during the 
Miocene (Figure 5.2).

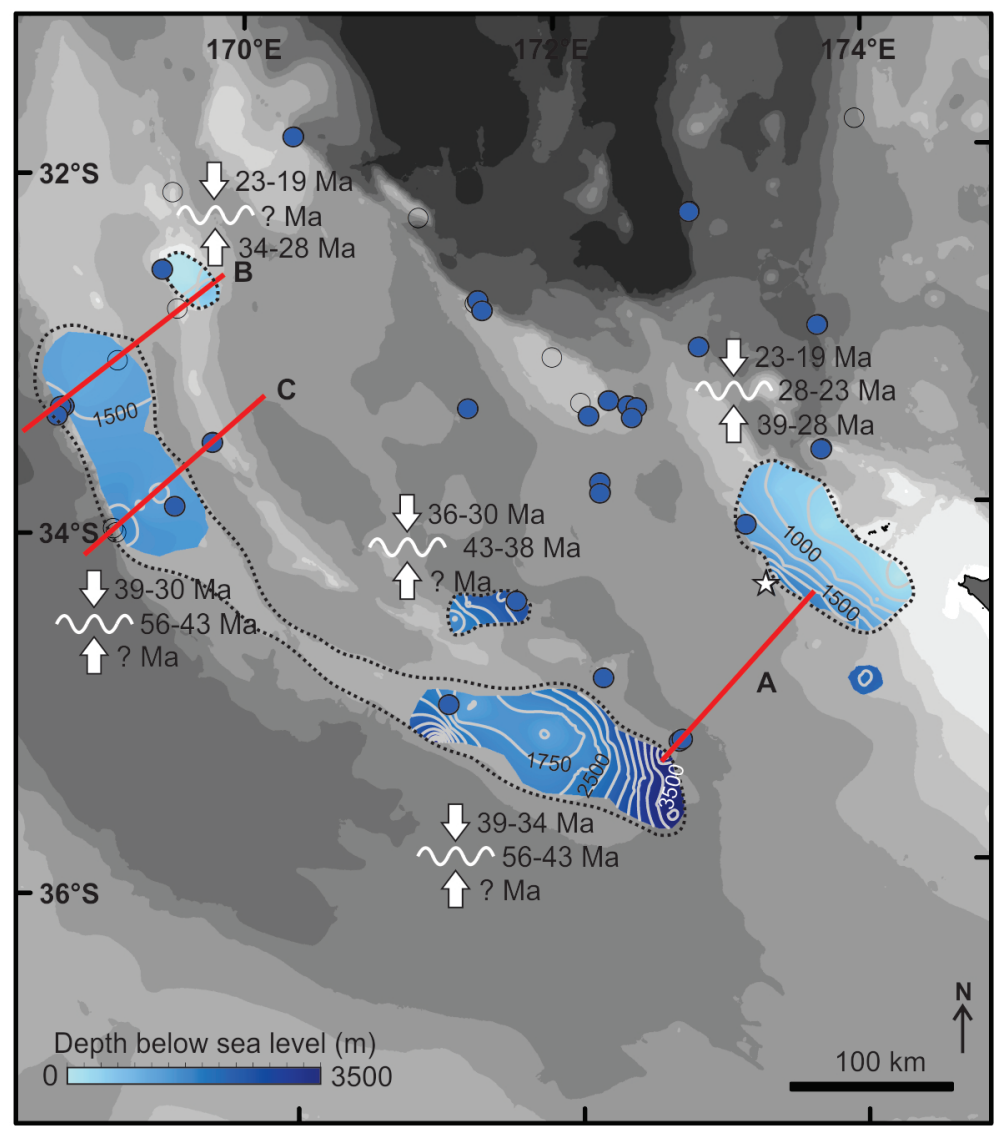

Figure 5.2: Map of depth-converted wave ravinement surfaces across Reinga Basin with a 250 $\mathrm{m}$ contour interval. Up arrows indicate the inferred time of uplift based on the minimum age of truncated strata beneath the wave ravinement surface. Down arrows indicate the inferred time of subsidence based on the maximum age of strata overlying the wave ravinement surface. Wiggly white lines indicate the inferred time of wave ravinement is based on ages of reworked shallow-water fauna in dredge (blue circles) and borehole samples (white star). Dashed lines indicate areas of shallow-water at the time of wave ravinement. Red lines indicate locations of seismic sections in Figure 5.3.

Wave ravinement surfaces across Reinga Basin are covered by thin amounts of sediment. Assuming negligible compaction of underlying material, adding $600 \mathrm{~ms}^{-1}$ depth of twoway-time of sediment thickness to the observed seafloor depth is an adequate correction to obtain tectonic subsidence values and remove the effect of sediment loading (Crough, 1983). Correcting bathymetry for sediment loading by a few hundred metres of pelagic ooze was found to be negligible, as compared to directly determining the depth of the erosion surface and ignoring sediment loading effects. 


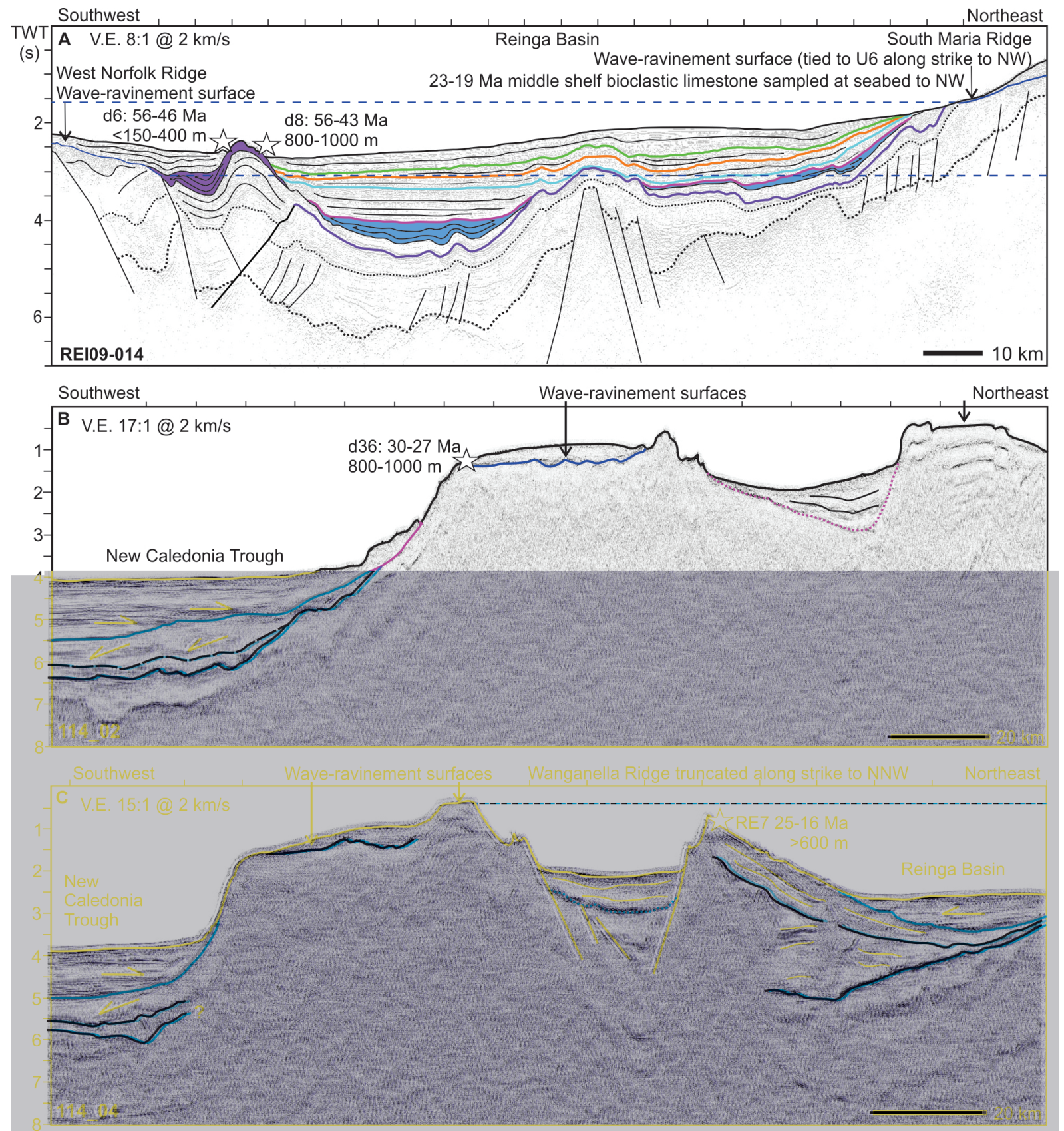

Figure 5.3: (A) Line drawing of seismic reflection line REI09-014 across Reinga Basin. Wave ravinement surfaces are identified on West Norfolk Ridge $(>2 \mathrm{~s}$ twt) and South Maria Ridge $(<2 \mathrm{~s}$ twt). U4 (purple) and U5 (blue) growth strata are associated with different phases of compression that lead to differential uplift of the ridges. Dredged syn-tectonic bioclastic limestones constrain the timing of West Norfolk Ridge wave ravinement at 56-43 Ma, and subsidence after $43 \mathrm{Ma}$. Fauna in U6 at Site U1508 constrain South Maria Ridge wave ravinement to 28-23 Ma. Dreged middle-shelf bioclastic limestone indicates subsidence after 23-19 Ma. (B) Seismic reflection line 114-02 across New Caledonia Trough and West Norfolk Ridge shows two wave ravinement surfaces. The deeper surface $(\sim 1.5 \mathrm{~s} \mathrm{twt})$ is continuous along West Norfolk Ridge. It is overlain by dredged undeformed middle bathyal calcareous mudstones that indicate subsidence to middle bathyal depths by 30-27 Ma. The shallower surface $(\sim 0.5 \mathrm{~s}$ twt) is along northern Wanganella Ridge and truncated following early Oligocene uplift. (C) Seismic reflection line 114-04 across West Norfolk and Wanganella ridges. Wanganella Ridge is not eroded and dredged limestone indicates the ridge was in middle bathyal conditions at 25-16 Ma. 


\subsection{Volcanic history}

The Pacific Ring of Fire was created during the Eocene when subduction initiated throughout the western Pacific. The oldest Cenozoic volcanic rocks with Tonga-Kermadec subduction affinities were dredged from the Tonga forearc (52-48 Ma and 46-40 Ma) (Duncan et al., 1985; Meffre et al., 2012), and the D'Entrecasteaux Ridge near New Caledonia (56-34 Ma) (Mortimer et al., 2014a). Subduction-related volcanism sampled at Three Kings Ridge have ages in the range of 32-22 Ma, indicating southward migration of volcanism towards northern New Zealand (Mortimer et al., 1998, 2007).

The onset of widespread volcanism is geochemically dated at $23 \mathrm{Ma}$ onshore, but older volcanic deposits, potentially derived from offshore volcanoes, have stratigraphic ages of 25-23 Ma (Hayward, 1993; Hayward et al., 2001). Ages are potentially controversial as K-Ar dates in disagreement with biostratigraphic ages were rejected. Based on seismic stratigraphy, the onset of volcanism offshore was previously dated at 22 Ma (Herzer, 1995). Based on seismic ties to Waka Nui-1, the onset of volcanism is dated at $25 \mathrm{Ma}$ in this study. Northland Arc volcanism is coincident with the oldest known age of volcanism in the Three Kings arc (Mortimer et al., 1998). There is no eruptive trend for offshore Northland volcanoes, and they were active until $16 \mathrm{Ma}$ (Herzer, 1995). It must be noted that the type of magmatism and geochemical ages of almost all offshore volcanoes are unknown. There was a regional southward and eastward migration of arc-related volcanic centres onshore (Figure 5.4): Northland (23-16 Ma), Coromandel (16-4 Ma), Taranaki (12 Ma), and finally to the Central Volcanic Region and opening of the Havre Trough back-arc basin (4-0 Ma) (Stern, 1985; Wright et al., 1996; Hayward et al., 2001; Stern et al., 2006).

Evidence for non-arc volcanism is found within volcaniclastic conglomerates of the Waitemata Group onshore Northland (Shane et al., 2010). Conglomerates include a single megaclast of basaltic lava with ocean island basalt affinities and is precisely Ar-Ar dated at 20 Ma. Location of the source volcano is unknown, but Shane et al. (2010) speculate north and east of Northland. This shows that there were potentially a series of non-arc volcanoes erupting at a similar time to arc-related volcanoes.

Evidence from Site U1508 and seismic mapping suggest that arc-type volcanism may have occurred during 34-28 Ma to the north of New Zealand (i.e. 5-11 Myr earlier than Northland). Based on location, the volcano near Site U1508 could be part of the Northland Arc (Herzer, 1995). It is also possible that the volcano could be related to oldest Three Kings Ridge volcanism (Mortimer et al., 2017). However, it is impossible to assign arc affinity without geochemical analyses of volcanic clasts within the borehole. Based on seismic character and distribution of volcanoes in Reinga Basin, there is an apparent age progression with the oldest ages (34-28 Ma) in the northwest, to Northland (25-23 Ma) (Figure 5.4). 


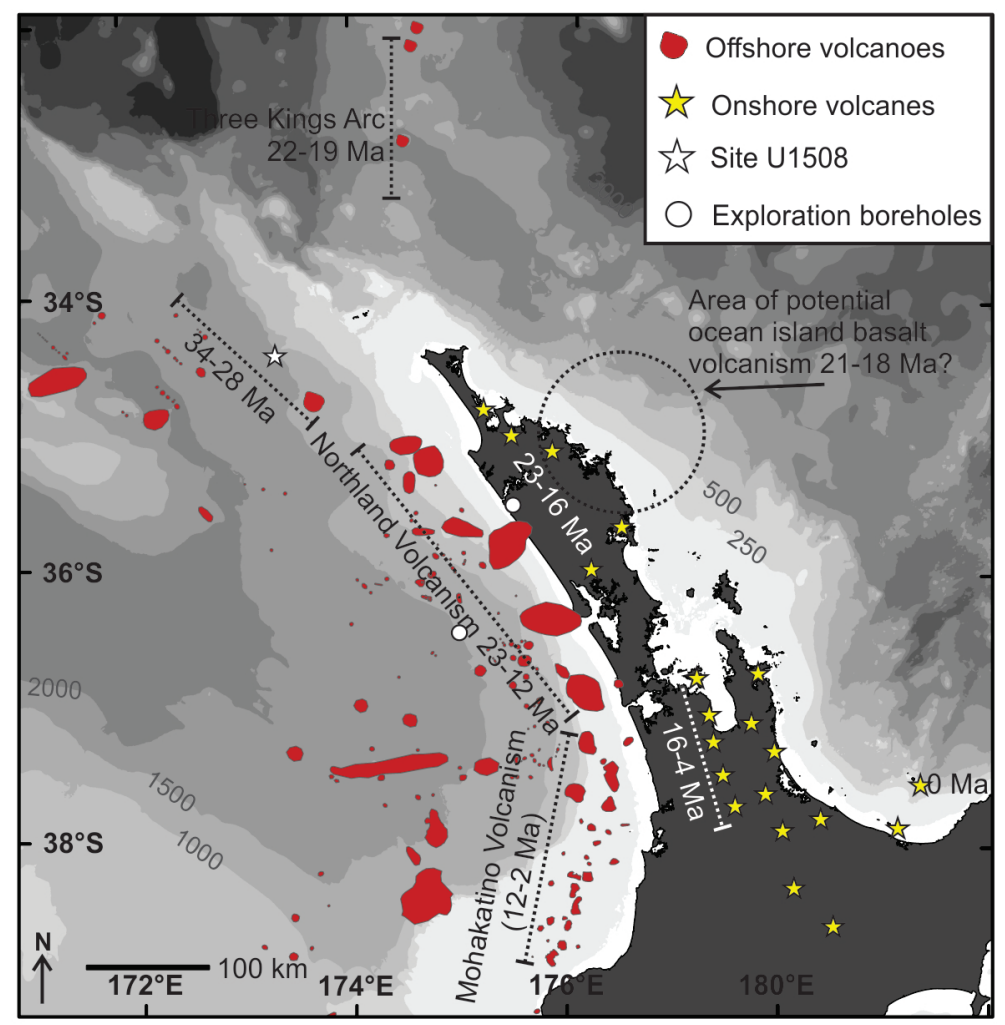

Figure 5.4: Map of volcanism in northwestern New Zealand. Volcanism is inferred to initiate near IODP Site U1508 at 34-28 Ma. Active offshore volcanism migrates southward to Northland Basin and is dated at 23-12 Ma (Herzer, 1995; Hayward et al., 2001). Dredge samples from Three Kings Ridge indicate the end of arc activity in northern New Zealand at 22-19 Ma (Mortimer et al., 1998). Back-arc extension and volcanism migrates south to Taranaki Basin at 12-2 Ma. Ages of Northland volcanism is from Herzer (1995) and Hayward et al. (2001). Ages of Taranaki volcanism are from Giba et al. (2013). Volcanism is also dated onshore and K-Ar ages of low-potash andesites (yellow stars) indicate that it migrates southwards from $23 \mathrm{Ma}$ in Northland, to $4 \mathrm{Ma}$ in Coromandel and $0 \mathrm{Ma}$ in the Havre Trough. Area of potential ocean island basalt volcanism at 21-18 Ma is from Shane et al. (2010). Figure modified from Stern et al. (2006) and (Mortimer et al., 2007).

\subsection{Conclusions}

This thesis investigates and characterises the Eocene to Miocene tectonostratigraphy of Reinga Basin. Revised seismic-stratigraphic mapping and ties to sampled sediment at dredge and borehole sites provide strong age constraints on the basin history. The results of this thesis are summarised below.

Eight seismic-stratigraphic units were mapped using the principles of seismic stratigraphy. U4 and U5 contain faulted, folded and onlapping reflectors that indicate progressive deformation. Deformed units are stratigraphically older in northwest Reinga Basin, and deformation progressively increases southwards. U6 and U7 contain fanning reflectors that onlap and downlap, recording continued folding, uplift, subsidence, erosion and volcanic input at basin 
margins. U6 also comprises two intra-unit volcaniclastic fans. U8 and U9 comprise sequences that drape older units.

Six lithostratigraphic units were analysed to assign age, lithology and paleoenvironment to seismic units. U4 comprises deformed middle to lower bathyal early to middle Eocene limestones that contain reworked shallow-water fauna. U5 comprises late Eocene deformed nannofossil chalk and cherty limestone that records uplift at Site U1508. U6 comprises late Oligocene foraminiferal ooze and chalk that contains volcanic material and reworked shallowwater and land-proximal taxa. U7 comprises early to middle Miocene foraminiferal ooze and chalk at U1508 and middle-shelf micritic limestone along South Maria Ridge. U8 comprises Late Miocene clayey nannofossil ooze and U9 comprises foraminiferal ooze with nannofossils and bioclasts and records conditions similar to the present-day.

The recognition of Paleogene tectonic events in North Island has been hindered by their subtle expression and an extreme overprint by Neogene tectonics. In Reinga Basin, Paleogene tectonic expression is much stronger than onshore, and there has been little or no Neogene overprint. The integration of biostratigraphy with seismic stratigraphy has hence allowed constraint on the timing and style of Paleogene tectonic signals adjacent to northern North Island.

The first signs of folding, uplift, and wave ravinement on West Norfolk Ridge at 56-43 Ma pre-date the onset of rapid seafloor spreading south of New Zealand at $\sim 43 \mathrm{Ma}$, and approximately correspond to the period of tectonic change and subduction initiation that is recognised throughout the western Pacific. Convergence and uplift then shifted to the northeastern margin of Reinga Basin, where the growth of Reinga-South Maria-Northland ridges was associated with folding and reverse faulting 39-34 Ma that is evident south of Northland (Taranaki Fault). Topography and slope development resulted in allochthon emplacement followed by a transition to arc volcanism that progressed from northwest to southeast during the interval 34-23 Ma.

This study provides a new framework for understanding the early history of the southern Kermadec-Hikurangi subduction zone, and hence provides the southern-most piece in the puzzle of how subduction initiated throughout the western Pacific during the Paleogene. 


\section{References}

Aitchison, J. C., Clarke, G. L., Meffre, S., and Cluzel, D. (1995). Eocene arc-continent collision in New Caledonia and implications for regional southwest Pacific tectonic evolution. Geology, 23(2):161-164.

ARCO Petroleum NZ Inc. (1988). Final Well Report, Kora-1 Kora-1A. PPL 38447. Ministry of Economic Development Unpublished Petroleum Report PR1374.

Bache, F., Mortimer, N., Sutherland, R., Collot, J., Rouillard, P., Stagpoole, V. M., and Nicol, A. (2014a). Seismic stratigraphic record of transition from Mesozoic subduction to continental breakup in the Zealandia sector of eastern Gondwana. Gondwana Research, 26(3-4):1060-1078.

Bache, F., Stagpoole, V. M., and Sutherland, R. (2012a). Seismic stratigraphy of the Reinga Basin, northwest New Zealand: tectonic and petroleum implications. In Advantage NZ: New Zealand Petroleum Conference.

Bache, F., Sutherland, R., and King, P. R. (2014b). Use of ancient wave-ravinement surfaces to determine palaeogeography and vertical crustal movements around New Zealand. New Zealand Journal of Geology and Geophysics, 57(4):459-467.

Bache, F., Sutherland, R., Mortimer, N., Browne, G. H., Lawrence, M. J. F., Black, J. A., Flowers, M., Rouillard, P., Pallentin, A., Woelz, S., Wilcox, S., Hines, B., Jury, S., and Roop, H. (2014c). Tangaroa TAN1312 Voyage Report: Dredging Reinga and Aotea basins to constrain seismic Stratigraphy and Petroleum systems (DRASP), NW New Zealand. Number GNS Science Report 2014/05. GNS Science Report 2014/05.

Bache, F., Sutherland, R., Stagpoole, V. M., Herzer, R. H., Collot, J., and Rouillard, P. (2012b). Stratigraphy of the southern Norfolk Ridge and the Reinga Basin: A record of initiation of Tonga-Kermadec-Northland subduction in the southwest Pacific. Earth and Planetary Science Letters, 321-322:41-53.

Baldwin, S. L., Rawling, T., and Fitzgerald, P. G. (2007). Thermochronology of the New Caledonian high pressure terrane: Implications for the middle Tertiary plate boundary process in the SW Pacific. Geological Society of America Special Paper, 419(06):117-134. 
Ballance, P. F. (1976). Evolution of the Upper Cenozoic Magmatic Arc and plate boundary in northern New Zealand. Earth and Planetary Science Letters, 28(3):356-370.

Ballance, P. F. and Campbell, J. D. (1993). The Murihiku arc-related basin of New Zealand (Triassic-Jurassic). In In: Ballance, P.F. (Ed,), South Pacific Sedimentary Basins, Sedimentary Basins of the World, volume 2, pages 21-33. Elsevier Amsterdam.

Ballance, P. F. and Spörli, K. B. (1979). Northland Allochthon. Journal of the Royal Society of New Zealand, 9(2):259-275.

Baur, J., Sutherland, R., and Stern, T. A. (2014). Anomalous passive subsidence of deepwater sedimentary basins: A prearc basin example, southern New Caledonia Trough and Taranaki Basin, New Zealand. Basin Research, 26(2):242-268.

Black, P. M. (1994). The "Waipapa Terrane", North Island, New Zealand: Subdivision and correlation. Geosci. Rep. Shizuoka Univ., 20:55-62.

Bradshaw, J. D. (2004). Northland allochthon: An alternative hypothesis of origin. New Zealand Journal of Geology and Geophysics, 47(3):375-382.

Brook, F. J. and Hayward, B. W. (1989). Geology of autochthonous and allochthonous sequences between Kaitaia and Whangaroa, northern New Zealand. New Zealand Geological Survery record 36.

Brook, F. J., Isaac, M. J., and Hayward, B. W. (1988). Geology of autochthonous and allochthonous strata in the Omahuta area, northern New Zealand, volume 32. Dept. of Scientific and Industrial Research.

Brothers, R. N. and Delaloye, M. (1982). Obducted ophiolites of North Island, New Zealand: Origin, age, emplacement and tectonic implications for tertiary and quaternary volcanicity. New Zealand Journal of Geology and Geophysics, 25(3):257-274.

Browne, G. H., Lawrence, M. J. F., Mortimer, N., Clowes, C., Morgans, H. E. G., Hollis, C. J., Beu, A. G., Black, J. A., Sutherland, R., and Bache, F. (2016). Stratigraphy of Reinga and Aotea basins, NW New Zealand: constraints from dredge samples on regional correlations and reservoir character. New Zealand Journal of Geology and Geophysics, 59(3):396-415.

Browne, G. H., Lawrence, M. J. F., Mortimer, N., Ventura, G. T., Clowes, C., Morgans, H. E. G., Seward, D., Barker, P. B., Lyndsell, B. M., Beu, A. G., and Hollis, C. J. (2014). Analysis of Rock Samples Collected During the TAN1312 Dredging Survey (DRASP) of Reinga and Aotea basins, NW New Zealand. 
Burns, R. E., Andrews, J. E., van der Lingen, G. J., Churkin Jr, M., Galehouse, J. S., Packham, G. H., Davies, T. A., Kennett, J. P., Dimitrica, P., Edwards, A. R., and Von Herzen, R. P. (1973a). Site 206: Initital reports of the Deep Sea Drilling Project 21. Washington, D.C., U.S. Government Printing Office.

Burns, R. E., Andrews, J. E., van der Lingen, G. J., Churkin Jr, M., Galehouse, J. S., Packham, G. H., Davies, T. A., Kennett, J. P., Dimitrica, P., Edwards, A. R., and Von Herzen, R. P. (1973b). Site 20\%: Initial Reports of the Deep Sea Drilling Project 21.

Carter, L. (1969). The Mahurangi Limestone from Puketotara Peninsula, Northland, New Zealand. New Zealand Journal of Geology and Geophysics, 12(1):104-118.

Carter, L. (1971). Stratigraphy and sedimentology of the Waitemata Group, Puketotara Peninsula, Northland. New Zealand Journal of Geology and Geophysics, 14(1):169-191.

Carter, L. (1992). Acoustical characterisation of seafloor sediments and its relationship to active sedimentary processes in Cook Strait, New Zealand. New Zealand Journal of Geology and Geophysics, 35:289-300.

Carter, L. and Herzer, R. H. (1979). The hydraulic regime and its potential to transport sediment on the Canterbury continental shelf. New Zealand Oceanographic Institute Memoir 83.

Carter, L., Lewis, K. B., and Davey, F. (1991). Seafloor stability along the Cook Strait power cable corridor. In 10th Australasian Conference on Coastal and Ocean Engineering, pages $565-570$.

Carter, R. M. (1985). The Mid-Oligocene Marshall Paraconformity, New Zealand: Coincidence with global eustatic sea-level fall or rise? The Journal of Geology, 93(3):359-371.

Carter, R. M., Carter, L., and McCave, I. N. (1996). Current controlled sediment deposition from the shelf to the deep ocean: The Cenozoic evolution of circulation through the SW Pacific gateway. Geologische Rundschau, 85(3):438-451.

Carter, R. M., Fulthorpe, C. S., and Lu, H. (2004). Canterbury drifts at Ocean Drilling Program Site 1119, New Zealand: climatic modulation of southwest Pacific intermediate water flows since 3.9 Ma. Geology, 32(11):1005--1008.

Carter, R. M. and Norris, R. J. (1976). Cainozoic history of southern New Zealand: An accord between geological observations and plate-tectonic predictions. Earth and Planetary Science Letters, 31(1):85-94.

Catuneanu, O. (2006). Principles of sequence stratigraphy, volume 44. Elsevier. 
Catuneanu, O., Abreu, V., Bhattacharya, J. P., Blum, M. D., Dalrymple, R. W., Eriksson, P. G., Fielding, C. R., Fisher, W. L., Galloway, W. E., Gibling, M. R., Giles, K. A., Holbrook, J. M., Jordan, R., Kendall, C. G. S. C., Macurda, B., Martinsen, O. J., Miall, A. D., Neal, J. E., Nummedal, D., Pomar, L., Posamentier, H. W., Pratt, B. R., Sarg, J. F., Shanley, K. W., Steel, R. J., Strasser, A., Tucker, M. E., and Winker, C. (2009). Towards the standardization of sequence stratigraphy. Earth-Science Reviews, 92(1-2):1-33.

Catuneanu, O., Galloway, W. E., Kendall, C. G. S. C., Miall, A., Posamentier, H. W., Strasser, A., and Tucker, M. E. (2011). Sequence stratigraphy: methodology and nomenclature. Newsletters on stratigraphy, 44(3):173-245.

Chiswell, S. M., Bostock, H. C., Sutton, P. J. H., and Williams, M. J. M. (2015). Physical oceanography of the deep seas around New Zealand: A review. New Zealand journal of marine and freshwater research.

Cluzel, D., Aitchison, J. C., and Picard, C. (2001). Tectonic accretion and underplating mafic terranes in the late Eocene intraoceanic fore-arc of New Caledonia (Southwest Pacific): Geodynamic implications. Tectonophysics, 340(1-2):23-59.

Cluzel, D., Maurizot, P., Collot, J. Y., and Sevin, B. (2012). An outline of the Geology of New Caledonia; from Permian-Mesozoic Southeast Gondwanaland active margin to Cenozoic obduction and supergene evolution. Episodes, 35(1):72-86.

Cluzel, D., Meffre, S., Maurizot, P., and Crawford, A. J. (2006). Earliest Eocene (53 Ma) convergence in the Southwest Pacific : evidence from pre-obduction dikes in the ophiolite of New Caledonia. Terra Nova, 18(6):395-402.

Cook, R. A., Sutherland, R., and Zhu, H. (1999). Cretaceous-Cenozoic geology and petroleum systems of the Great South Basin, New Zealand, volume 20. Institute of Geological \& Nuclear Sciences Monograph, Lower Hutt, New Zealand.

Crawford, A. J., Meffre, S., and Symonds, P. (2003). 120 to 0 Ma tectonic evolution of the southwest Pacific and analogous geological evolution of the 600 to 220 Ma Tasman Fold Belt System. Geological Society of Australia Special Publication, 22(Figure 1):377-397.

Crough, S. T. (1983). The correction for sediment loading on the seafloor. Journal of Geophysical Research, 88(B8):6449-6454.

Davy, B. W. (2014). Rotation and offset of the Gondwana convergent margin in the New Zealand region following Cretaceous jamming of Hikurangi Plateau large igneous province subduction. Tectonics, 33:1577-1595. 
Davy, B. W., Hoernle, K., and Werner, R. (2008). Hikurangi Plateau: Crustal structure, rifted formation, and Gondwana subduction history. Geochemistry, Geophysics, Geosystems, $9(7)$.

Demarest, J. M. and Kraft, J. C. (1987). Stratigraphic record of Quaternary sea levels: implications for more ancient strata. In Sea-level fluctuation and coastal evolution, volume 41, pages 223-240. SEPM Special Publication.

Diamond Shamrock Exploration Oil Co NZ (1984). Final Well Report Taimana-1 PPL 38109. Ministry of Economic Development Unpublished Petroleum Report PR1026.

DiCaprio, L., Müller, R. D., Gurnis, M., and Goncharov, A. (2009). Linking active margin dynamics to overriding plate deformation: Synthesizing geophysical images with geological data from the Norfolk Basin. Geochemistry, Geophysics, Geosystems, 10(1):1-14.

Duncan, R. A., Vallier, T. L., and Falvvey, D. (1985). Volcanic episodes at 'Eua, Tonga Islands. In Geology and Offshore Resources of Pacific Islands. Circum Pacific Council for Energy and Mineral Resource, Houston, Texas.

Dunham, R. J. (1962). Classification of carbonate rocks according to depositional textures. In In: Ham W. E., editor. Classification of carbonate rocks. Memoir of the American Association of Petroleum Geologists 1., pages 108-121. AAPG Special Volumes, Tulsa, OK.

Eade, J. V. (1988). The Norfolk Ridge system and its margins. In Nairn, A.E.M., Stehli, F.G., Uyeda, S. (Eds.), The Pacific Ocean. The Ocean Basins and Margins, volume 7B, pages 303-324. Plenum Press, New York.

Edbrooke, S. W. (2001). Geology of the Auckland Area: Scale 1: 250,000. Institute of Geological \& Nuclear Sciences.

Edbrooke, S. W. and Brook, F. J. (2009). Geology of the Whangarei area. Lower Hutt: Institute of Geological $\& 3$ Nuclear Sciences, 1(250):0.

Edbrooke, S. W., Crouch, E. M., Morgans, H. E. G., and Sykes, R. (1998). Late Eocene Oligocene Te Kuiti Group at Mount Roskill, Auckland, New Zealand. New Zealand Journal of Geology and Geophysics, 41(1):85-93.

Evans, R. B. (1989). An outcrop of Waitemata Group strata at Waihou Valley, Hokianga, New Zealand, and implications for Northland Stratigraphy. Royal Society of New Zealand bulletin, 26:85-93.

Field, B. D., Browne, G. H., and Bryan, W. (1989). Cretaceous and Cenozoic sedimentary basins and geological evolution of the Canterbury region, South Island, New Zealand. Institute of Geological \& Nuclear Sciences Monograph, Lower Hutt, New Zealand. 
Folk, R. L. (1962). Spectral subdivision of limestone types. In In: Ham W. E., editor. Classification of carbonate rocks. Memoir of the American Association of Petroleum Geologists 1., pages 62-84. AAPG Special Volumes, Tulsa, OK.

Fulthorpe, C. S., Carter, R. M., Miller, K. G., and Wilson, J. (1996). Marshall Paraconformity: A mid-Oligocene record of inception of the Antarctic Circumpolar Current and coeval glacio-eustatic lowstand? Marine and Petroleum Geology, 13(1):61-77.

Gaina, C., Müller, R. D., Royer, J., Stock, J., Hardebeck, J., and Symonds, P. (1998). The tectonic history of the Tasman Sea: A puzzle with 13 pieces. Journal of Geophysical Research: Solid Earth, 103(B6):12413-12433.

GECO NZ (1982). GECO spec - Northland Basin offshore NZ. Open-file Petroleum Report 959. Ministry of Commerce, Wellington.

Giba, M., Nicol, A., and Walsh, J. J. (2010). Evolution of faulting and volcanism in a back-arc basin and its implications for subduction processes. Tectonics, 29:18.

Giba, M., Walsh, J. J., Nicol, A., Mouslopoulou, V., and Seebeck, H. (2013). Investigation of the spatio-temporal relationship between normal faulting and arc volcanism on millionyear time scales. Journal of the Geological Society, 170(6):951-962.

Gurnis, M., Hall, C., and Lavier, L. (2004). Evolving force balance during incipient subduction. Geochemistry, Geophysics, Geosystems, 5(7).

Hatherton, T. and Sibson, R. H. (1970). Junction magnetic anomaly north of waikato river. New Zealand Journal of Geology and Geophysics, 13(3):655-662.

Hay, R. F. (1960). The geology of Mangakahia subdivision. New Zealand Dept. of Scientific and Industrial Research.

Hay, R. F. (1975). Sheet NY Doubtless Bay. Geological map of New Zealand 1:63,360. Dept. of Scientific and Industrial Research, Wellington.

Hayward, B. W. (1986). A Guide to Paleoenvironmental Assessment Using New Zealand Cenozoic Foraminiferal Faunas. New Zealand Geological Survey report PAL 109, Lower Hutt: New Zealand Geological Survey.

Hayward, B. W. (1993). The tempestuous 10 million year life of a double arc and intra-arc basin - New Zealand's Northland Basin in the Early Miocene. Sedimentary basins of the world, 2:113-142.

Hayward, B. W. (1999). Recent New Zealand deep-water benthic foraminifera: Taxonomy, ecologic distribution, biogeography and use in paleoenvironmental assessment. Institute of Geological \& Nuclear Sciences Monograph 21, Lower Hutt. 
Hayward, B. W., Black, P. M., Smith, I. E. M., Ballance, P. F., Itaya, T., Doi, M., Takagi, M., Bergman, S., Adams, C. J., Herzer, R. H., and Robertson, D. J. (2001). K-Ar ages of early Miocene arc-type volcanoes in northern New Zealand. New Zealand Journal of Geology and Geophysics, 44(2):285-311.

Hayward, B. W., Brook, F. J., and Isaac, M. J. (1989). Cretaceous to Middle Tertiary stratigraphy, paleogeography and tectonic history of Northland, New Zealand. Journal of the Royal Society of New Zealand, 26:1989.

Hematite Petroleum NZ Ltd (1970). Mangaa-1 (Offshore). Ministry of Economic Development unpublished Petroleum Report 554.

Herzer, R. H. (1995). Seismic stratigraphy of a buried volcanic arc, Northland, New Zealand and implications for Neogene subduction. Marine and Petroleum Geology, 12(5):511-531.

Herzer, R. H., Chaproniere, G. C. H., Edwards, A. R., Hollis, C. J., Pelletier, B., Raine, J. I., Scott, G. H., Stagpoole, V. M., Strong, C. P., Symonds, P., Wilson, G. J., and Zhu, H. (1997). Seismic stratigraphy and structural history of the Reinga Basin and its margins, southern Norfolk Ridge system. New Zealand Journal of Geology and Geophysics, 40(4):425-451.

Herzer, R. H., Davy, B. W., Mortimer, N., Quilty, P. G., Chaproniere, G. C. H., Jones, C. M., Crawford, A. J., and Hollis, C. J. (2009). Seismic stratigraphy and structure of the Northland Plateau and the development of the Vening Meinesz transform margin, SW Pacific Ocean. Marine Geophysical Researches, 30(1):21-60.

Herzer, R. H. and Mascle, J. (1996). Anatomy of a continent-backarc transform - The Vening Meinesz Fracture Zone northwest of New Zealand. Marine Geophysical Researches, 18(718):401-427.

Herzer, R. H., Mascle, J., Davy, B. W., Ruellan, E., Mortimer, N., and Laporte, C. (2000). New constraints on the New Zealand - South Fiji Basin continent-back-arc margin. Marine Geology, 330(10):701-708.

Herzer, R. H., Sykes, R., Killops, S. D., Funnell, R. H., Burggraf, D. R., Townend, J., Raine, J. I., and Wilson, G. J. (1999). Cretaceous carbonaceous rocks from the Norfolk Ridge system, Southwest Pacific: Implications for regional petroleum potential. New Zealand Journal of Geology and Geophysics, 42(1):57-73.

Hollis, C. J. and Hanson, J. A. (1991). Well-preserved late Paleocene Radiolaria from Tangihua Complex, Camp Bay, eastern Northland. Tane, 33:65-76.

Holt, W. E. and Stern, T. A. (1994). Subduction, platform subsidence, and foreland thrust loading: The late Tertiary development of Taranaki Basin, New Zealand. Tectonics, 13(5):1068-1092. 
Hornibrook, N., Edwards, A. R., Mildenhall, D. C., Webb, P. N., and Wilson, G. J. (1976). Major displacements in Northland, New Zealand; micropaleontology and stratigraphy of Waimamaku-1 and -2 wells. New Zealand Journal of Geology and Geophysics, 19(2):233263.

Hunt, T. (1978). Stokes magnetic anomaly system. New Zealand Journal of Geology and Geophysics, 21(5):595-606.

Isaac, M. J., Brook, F. J., and Hayward, B. W. (1988). The Cretaceous sequence at Whatuwhiwhi, Northland: New Zealand, and its paleogeographic significance. Dept. of Scientific and Industrial Research.

Isaac, M. J., Herzer, R. H., Brook, F. J., and Hayward, B. W. (1994). Cretaceous and Cenozoic sedimentary basins of Northland, New Zealand. Institute of Geological \& Nuclear Sciences Monograph, 8.

Isaac, M. J., Rattenbury, M. S., Heron, D. W., and Reay, M. B. (1996). Geology of the Kaitaia Area: Scale 1: 250,000. Institute of Geological \& Nuclear Sciences.

Jiao, R., Seward, D., Little, T. A., Herman, F., and Kohn, B. P. (2017). Constraining provenance, thickness and erosion of nappes using low-temperature thermochronology: the Northland Allochthon, New Zealand. Basin Research, 29(1):81-95.

Kamp, P. J. J. (1986). Relationship of the west coast, North Island, igneous bodies to the mid-cenozoic challenger rift system and subduction of the pacific plate. New Zealand Journal of Geology and Geophysics, 29(1):51-60.

Kamp, P. J. J. (1999). Tracking crustal processes by FT thermochronology in a forearc high (Hikurangi margin, New Zealand) involving Cretaceous subduction termination and mid-Cenozoic subduction initiation. Teconophysics, 307:313-343.

Kamp, P. J. J. and Furlong, K. P. (2006). Neogene Plate Tectonic Reconstructions and Geodynamics of North Island Sedimentary Basins: Implications for the Petroleum Systems. In 2006 New Zealand Petroleum Conference Proceedings, pages 6-10.

King, P. R. (2000a). New Zealand's changing configuration in the last 100 million years: place tectonics, basin development, and depositional setting. In 2000 New Zealand Petroleum Conference Proceedings, volume 15. Crown Minerals, Ministry of Commerce, Wellington.

King, P. R. (2000b). Tectonic reconstructions of New Zealand: 40 Ma to the Present. New Zealand Journal of Geology and Geophysics, 43(4):611-638.

King, P. R., Naish, T. R., Browne, G. H., Field, B. D., and Edbrooke, S. W. (1999). Cretaceous to Recent sedimentary patterns in New Zealand. Institute of Geological \& Nuclear Sciences, Lower Hutt. 
King and Thrasher (1996). Cretaceous-Cenozoic Geology and Petroleum Systems of the Taranaki Basin, New Zealand, volume 13. Institute of Geological \& Nuclear Sciences.

Lafoy, Y., Brodien, I., Vially, R., and Exon, N. F. (2005). Structure of the basin and ridge system west of New Caledonia (Southwest Pacific): A synthesis. Marine Geophysical Researches, 26(1):37-50.

Laird, M. G. and Bradshaw, J. D. (2004). The break-up of a long-term relationship: The Cretaceous separation of New Zealand from Gondwana. Gondwana Research, 7(1):273286.

Larsen, J. M. and Spörli, K. B. (1989). Structure of the Tangihua ophiolites at Ahipara, Northland, New Zealand. Geology of Northland: accretion, allochthons and arcs at the edge of the New Zealand micro-continent. Royal Society of New Zealand Bulletin, 26:137-144.

MacKinnon, T. C. (1983). Origin of the Torlesse terrane and coeval rocks, South Island, New Zealand. Geological Society of America Bulletin1, 94(8):967-985.

Malahoff, A., Feden, R. H., and Fleming, H. S. (1982). Magnetic anomalies and tectonic fabric of marginal basins north of New Zealand. Journal of Geophysical Research: Solid Earth, 87(B5):4109-4125.

Malpas, J., Spörli, K. B., Black, P. M., and Smith, I. E. M. (1992). Northland ophiolite, New Zealand, and implications for plate tectonic evolution of the southwest Pacific. Geology, 20(2):149-152.

Marshall, J., Feary, D., and Zhu, H. (1994). Geological framework of the southern Lord Howe Rise/West Norfolk Ridge Region, Project 121.30, Post Cruise Report, Rig Seismic Survey 114. Australian Geological Survery Organisation, Canberra.

Maurizot, P. (2011). First sedimentary record of the pre-obduction convergence in New Caledonia: Formation of an Early Eocene accretionary complex in the north of Grande Terre and emplacement of the 'Montagnes Blanches' nappe. Bulletin de la Societe Geologique de France, 182(6):479-491.

McRae, S. G. (1972). Glauconite. Earth Science Reviews, 8:397-440.

Meffre, S., Falloon, T. J., Crawford, T. J., Duncan, R. A., Bloomer, S. H., and Wright, D. J. (2012). Basalts erupted along the Tongan fore arc during subduction initiation: Evidence from geochronology of dredged rocks from the Tonga fore arc and trench. Geochemistry, Geophysics, Geosystems, 13(12):1-17.

Milne, A. and Quick, R. (1999). Waka Nui-1 Well Completion Report. PEP 28602. Ministry of Economic Development New Zealand Unpublished Petroleum Report PR2436. 
Ministry of Economic Development (1993). Marine seismic survey, PEP38602, offshore Northland, CNL98 lines. Ministry of Economica Development New Zealand Unpublished Petroleum Report PR2174.

Ministry of Economic Development (1996). CNL95 Seismic Survey. CNL95a and CNL95b lines. PEP38602. Ministry of Economica Development New Zealand Unpublished Petroleum Report PR2207.

Ministry of Economic Development (2009a). Reinga 09 2D Seismic Survey. Ministry of Economic Development New Zealand Unpublished Petroleum Report PR3980.

Ministry of Economic Development (2009b). Stratus \& Reinga 2D PSTM Processing Report. Ministry of Economic Development New Zealand Unpublished Petroleum Report PR4060.

Ministry of Economic Development (2011). ATB10, DTB01, and DTB08 2D Seismic Processing Report. Ministry of Economic Development New Zealand Unpublished Petroleum Report PR4382.

Mitchell, J. S., Mackay, K. A., Neil, H. L., Mackay, E. J., Pallentin, A., and Notman, P. (2012). Undersea New Zealand, 1:5,000,000. National Institute of Water and Atmospheric Research Ltd (NIWA).

Mitchum Jr, R. M. and Vail, P. R. (1977). Seismic stratigraphy and global changes of sea level, Part 7: Seismic stratigraphic interpretation procedure. Seismic StratigraphyApplications to Hydrocarbon Exploration, pages 135-143.

Mitchum Jr, R. M., Vail, P. R., and Sangree, J. B. (1977a). Seismic stratigraphy and global changes of sea level: Part 6. Stratigraphic interpretation of seismic reflection patterns in depositional sequences: Section 2. Application of seismic reflection configuration to stratigraphic interpretation. American Association of Petroleum Geologists, 26:205-212.

Mitchum Jr, R. M., Vail, P. R., and Thompson, S. (1977b). Seismic stratigraphy and global changes of sea level: Part 2. The depositional sequence as a basic unit for stratigraphic analysis: Section 2. Application of seismic reflection configuration to stratigraphic interpretation. American Association of Petroleum Geologists, pages 53-62.

Moore, P. R. (1988). Stratigraphy, composition and environment of deposition of the Whangai Formation and associated Late Cretaceous-Paleocene rocks, eastern North Island, New Zealand, volume 100. New Zealand Geological Survey Bulletin.

Morley, C. K., Maczak, A., Rungprom, T., Ghosh, J., Cartwright, J. A., Bertoni, C., and Panpichityota, N. (2017). New style of honeycomb structures revealed on 3D seismic data indicate widespread diagenesis offshore Great South Basin, New Zealand. Marine and Petroleum Geology, 86:140-154. 
Mortimer, N. (2004). New Zealand's geological foundations. Gondwana Research, 7(1):261272.

Mortimer, N., Campbell, H. J., Tulloch, A. J., King, P. R., Stagpoole, V. M., Wood, R. A., Rattenbury, M. S., Sutherland, R., Adams, C. J., Collot, J., and Seton, M. (2017). Zealandia: Earth's hidden continent. GSA Today, 27(3):27-35.

Mortimer, N., Gans, P. B., Palin, J. M., Herzer, R. H., Pelletier, B., and Monzier, M. (2014a). Eocene and oligocene basins and ridges of the Coral Sea-New Caledonia region: Tectonic link between Melanesia, Fiji, and Zealandia. Tectonics, 33(7):1386-1407.

Mortimer, N., Herzer, R. H., Gans, P. B., Laporte-Magoni, C., Calvert, A. T., and Bosch, D. (2007). Oligocene-Miocene tectonic evolution of the South Fiji Basin and Northland Plateau, SW Pacific Ocean: Evidence from petrology and dating of dredged rocks. Marine Geology, 237(1-2):1-24.

Mortimer, N., Herzer, R. H., Gans, P. B., Parkinson, D. L., and Seward, D. (1998). Basement geology from Three Kings Ridge to West Norfolk Ridge, southwest Pacific Ocean: evidence from petrology, geochemistry and isotopic dating of dredge samples. Marine Geology, 148(3):135-162.

Mortimer, N., Herzer, R. H., Walker, N. W., Calvert, A. T., Seward, D., and Chaproniere, G. C. H. (2003). Cavalli Seamount, Northland Plateau, SW Pacific Ocean: a Miocene metamorphic core complex? Journal of the Geological Society, London, 160:971-983.

Mortimer, N., Rattenbury, M. S., King, P. R., Bland, K. J., Barrell, D. J. A. A., Bache, F., Begg, J. G., Campbell, H. J., Cox, S. C., Crampton, J. S., Edbrooke, S. W., Forsyth, P. J., Johnston, M. R., Jongens, R., Lee, J. M., Leonard, G. S., Raine, J. I., Skinner, D. N. B., Timm, C., Townsend, D. B., Tulloch, A. J., Turnbull, I. M., and Turnbull, R. E. (2014b). High-level stratigraphic scheme for New Zealand rocks. New Zealand Journal of Geology and Geophysics, 57(4):402-419.

Mortimer, N., Tulloch, A. J., Spark, R. N., Walker, N. W., Ladley, E., Allibone, A., and Kimbrough, D. L. (1999). Overview of the Median Batholith, New Zealand: A new interpretation of the geology of the Median Tectonic Zone and adjacent rocks. Journal of African Earth Sciences, 29(1):257-268.

Mountjoy, J. J., Barnes, P. M., and Pettinga, J. R. (2009). Morphostructure and evolution of submarine canyons across an active margin: Cook Strait sector of the Hikurangi Margin, New Zealand. Marine Geology, 260(1-4):45-68.

Nelson, C. S. and Hancock, G. E. (1984). Composition and origin of temperate skeletal carbonate sediments on South Maria Ridge, northern New Zealand. New Zealand journal of marine and freshwater research, 18(2):221-239. 
Nelson, C. S., Hancock, G. E., and Kamp, P. J. J. (1982). Shelf to basin, temperate skeletal carbonate sediments, Three Kings Plateau, New Zealand. Journal of Sedimentary Research, 52(3):717-732.

New Zealand Overseas Petroleum Ltd (2004). Kiwi-1 Well Completion Report. Ministry of Economic Development New Zealand Unpublished Petroleum Report 2995.

New Zealand Overseas Petroleum Ltd (2010). Pukeko-1 Well Completion Report. Ministry of Economic Development New Zealand Unpublished Petroleum Report 2928.

Nicholson, K. N., Black, P. M., Picard, C., Cooper, P., Hall, C. M., and Itaya, T. (2007). Alteration, age, and emplacement of the Tangihua Complex Ophiolite, New Zealand. New Zealand Journal of Geology and Geophysics, 50(2):151-164.

North American Commission on Stratigraphic Nomenclature (2005). North American stratigraphic code. AAPG Bulletin, 89(11):1547-1591.

NZ Oil and Gas Ltd (1990). Kahawai-1 Well Completion Report. PPL38451. Ministry of Economic Development New Zealand Unpublished Petroleum Report PR1878.

NZ Petroleum Exploration Co Ltd (1972). Waimamaku-2 explatory well. New Zealand Unpublished Openfile Petroleum Report PR525.

Odin, G. and Matter, A. (1981). De glauconiarum origine. Sedimentology, 28:611-641.

Palmer, J. A. and Andrews, P. B. (1993). Cretaceous-Tertiary sedimentation and implied tectonic controls on the structural evolution of Taranaki Basin, New Zealand. In Ballance, P. F., editor, Sedimentary Basins of the World, vol. 2, South Pacific Sedimentary Basins, volume 2, pages 309-328. Elsevier Amsterdam.

Raine, J. I., Beu, A. G., Boyes, A. F., Campbell, H. J., Cooper, R. A., Crampton, J. S., Crundwell, M. P., Hollis, C. J., Morgans, H. E. G., and Mortimer, N. (2015). Revised calibration of the New Zealand Geological Timescale: NTGT2015/1. New Zealand Journal of Geology and Geophysics, 58(4):398-403.

Rait, G. J. (2000). Thrust transport directions in the Northland Allochthon, New Zealand. New Zealand Journal of Geology and Geophysics, 43(2):271-288.

Rait, G. J., Chanier, F., and Waters, D. W. (1991). Landward- and seaward-directed thrusting accompanying the onset of subduction beneath New Zealand. Geology, 19(3):230-233.

Rankin, J. and Gray, G. (1988). Final Well Report Tua Tua No 1 \& 1A. PPL38087. Ministry of Economic Development New Zealand Unpublished Petroleum Report PR1389.

Reyners, M., Eberhart-Phillips, D., and Stuart, G. (2007). The role of fluids in lower-crustal earthquakes near continental rifts. Nature, 446(7139):1075-1078. 
Sangree, J. B. and Widmier, J. M. (1979). Interpretation of depositional facies from seismic data.

Schellart, W. P. (2007). North-eastward subduction followed by slab detachment to explain ophiolite obduction and Early Miocene volcanism in Northland, New Zealand. Terra Nova, 19(3):211-218.

Schellart, W. P., Lister, G. S., and Toy, V. G. (2006). A Late Cretaceous and Cenozoic reconstruction of the Southwest Pacific region: Tectonics controlled by subduction and slab rollback processes. Earth Science Reviews, 76(3-4):191-233.

Sdrolias, M., Müller, R. D., Mauffret, A., and Bernardel, G. (2004). Enigmatic formation of the Norfolk Basin, SW Pacific: A plume influence on back-arc extension. Geochemistry, Geophysics, Geosystems, 5(6).

Seton, M., Müller, R. D., Zahirovic, S., Gaina, C., Torsvik, T., Shephard, G., Talsma, A., Gurnis, M., Turner, M., Maus, S., and Chandler, M. (2012). Global continental and ocean basin reconstructions since 200Ma. Earth-Science Reviews, 113(3-4):212-270.

Shane, P., Strachan, L. J., and Smith, I. (2010). Redefining the Waitemata Basin, New Zealand: A new tectonic, magmatic, and basin evolution model at a subduction terminus in the SW Pacific. Geochemistry, Geophysics, Geosystems, 11(4):1-23.

Sharp, W. and Clague, D. (2006). 50-Ma Initiation of Hawaiian-Emperor Bend Records Major Change in Pacific Plate Motion. Science, 313(September):1281-1284.

Shell BP and Todd Oil Services Ltd. (1976). Well resume Tane-1 (Offshore). Ministry of Economic Development New Zealand Unpublished Petroleum Report PR698.

Shell BP and Todd Oil Services Ltd. (1981). Well Resume - Tangaroa-1 PPL 38048 Offshore Taranaki. Ministry of Economic Development Unpublished Petroleum Report PR793.

Shell BP and Todd Oil Services Ltd. (1984). Completion Report. Ariki-1 Well. PPL 38048. Ministry of Economic Development New Zealand Unpublished Petroleum Report PR1038.

Shell BP and Todd Oil Services Ltd. (1992). Taranga-1 Well Completion Report. PPl38444. Ministry of Economic Development Unpublished Petroleum Report PR1864.

Sheriff, R. E. and Geldart, L. P. (1995). Exploration seismology. Cambridge university press. Spörli, K. B. (1978). Mesozoic tectonics, North Island, New Zealand. Geological Society of America Bulletin, 89:415-425. 
Spörli, K. B. (1989). Exceptional structural complexity in turbidite deposits of the piggyback Waitemata Basin, Miocene, Auckland/Northland, New Zealand. Geology of Northland-accretion, allochthons and arcs at the edge of the New Zealand micro-continent. Royal Society of New Zealand Bulletin, 26:183-194.

Spörli, K. B. and Harrison, R. E. (2004). Northland allochthon infolded into basement, whangarei area, northern New Zealand. New Zealand Journal of Geology and Geophysics, 47(3):391-398.

Spörli, K. B. and Rowland, J. V. (2007). Superposed deformation in turbidites and synsedimentary slides of the tectonically active Miocene Waitemata Basin, northern New Zealand. Basin Research, 19(2):199-216.

Stagpoole, V. M. (2011). Two-way time-depth relationship for Waka Nui-1 well to aid geological interpretations of the offshore northwestern New Zealand. New Zealand Journal of Geology and Geophysics, 54(3):341-346.

Stagpoole, V. M., Neil, H., Black, J. A., Bland, K. J., Browne, G. H., Clark, M., Crutchley, G., Dunkin, M., Gorman, R., Lamarche, G., MacDiarmid, A., Nodder, S. D., Rowden, A., Sutton, P., Thompson, D., and Ventura, G. T. (2014). Reinga Basin petroleum prospectivity screening report.

Stagpoole, V. M. and Nicol, A. (2008). Regional structure and kinematic history of a large subduction back thrust: Taranaki Fault, New Zealand. Journal of Geophysical Research, 113(January):1-19.

Stagpoole, V. M., Reid, E., Browne, G. H., Bland, K. J., Ilg, B., Griffin, A. G., Herzer, R. H., and Uruski, C. I. (2009). Petroleum Prospectivity of the Reinga Basin, New Zealand. GNS Science Consultancy Report 2009/251.

Steinberger, B., Sutherland, R., and O'Connell, R. J. (2004). Prediction of Emperor-Hawaii seamount locations from a revised model of global plate motion and mantle flow. Nature, 430(6996):167-173.

Stern, T. A. (1985). A back-arc basin formed within continental lithosphere: The Central Volcanic Region of New Zealand. Tectonophysics, 112(1-4):385-409.

Stern, T. A. and Holt, W. E. (1994). Platform subsidence behind an active subduction zone. Nature, 368:233-236.

Stern, T. A., Stratford, W. R., and Salmon, M. (2006). Subduction evolution and mantle dynamics at a continental margin: Central North Island, New Zealand. Reviews of Geophysics, 44(4):1-36. 
Stratford, W. R., Sutherland, R., and Collot, J. (2018). Physical properties and seismicreflection interpretation of bathyal marine sediments affected by carbonate and silica diagenesis in the Tasman Sea. New Zealand Journal of Geology and Geophysics, 61(1):96111.

Strogen, D. P., Seebeck, H. C., Nicol, A., and King, P. R. (2017). Two-phase Cretaceous Paleocene rifting in the Taranaki Basin region, New Zealand; implications for Gondwana break-up. Journal of the Geological Society, 174(5):929-946.

Strong, C. P., Mildenhall, D. C., Raine, J. I., Wilson, G. J., and Edwards, A. R. (1999). Biostratigraphy of Waka Nui-1 offshore petroleum exploration well, Northland Basin, New Zealand. Institute of Geological \& Nuclear Sciences client report 1999/123, Lower Hutt.

Sutherland, R. (1995). The Australian-Pacific boundary and Cenozoic plate motions in the SW Pacific. Tectonics, 14(4):819-831.

Sutherland, R. (1999). Basement geology and tectonic development of the greater New Zealand region: an interpretation from regional magnetic data. Tectonophysics, 308(3):341-362.

Sutherland, R., Collot, J., Bache, F., Henrys, S., Barker, D. H. N., Browne, G. H., Lawrence, M. J. F., Morgans, H. E. G., Hollis, C. J., Clowes, C., Mortimer, N., Rouillard, P., Gurnis, M., Etienne, S., and Stratford, W. R. (2017). Widespread compression associated with Eocene Tonga-Kermadec subduction initiation. Geology, 45(4):355-358.

Sutherland, R., Collot, J., Lafoy, Y., Logan, G. A., Hackney, R., Stagpoole, V. M., Uruski, C. I., Hashimoto, T., Higgins, K., Herzer, R. H., Wood, R., Mortimer, N., and Rollet, N. (2010). Lithosphere delamination with foundering of lower crust and mantle caused permanent subsidence of New Caledonia Trough and transient uplift of Lord Howe Rise during Eocene and Oligocene initiation of Tonga-Kermadec subduction, western Pacific. Tectonics, 29(2):1-16.

Sutherland, R., Dickens, G. R., Blum, P., Agnini, C., Alegret, L., Asatryan, G., Bhattacharya, J. P., Bordenave, A., Chang, L., Collot, J., Cramwinckel, M. J., Dallanave, E., Drake, M. K., Etienne, S. J. G., Giorgioni, M., Gurnis, M., Harper, D. T., Huang, H. H. M., Keller, A., Lam, A., Li, H., Matsui, H., Morgans, H. E. G., Newsam, C., Park, Y. H., Pekar, S. F., Penman, D. E., Saito, S., Stratford, W. R., Westerhold, T., and Zhou, X. (2019a). Site U1508. In Sutherland, R., Dickens, G.R., Blum, P., and the Expedition 371 Scientists, Tasman Frontier Subduction Initiation and Paleogene Climate. Proceedings of the International Ocean Discovery Program, 371. International Ocean Discovery Program, College Station, TX. 
Sutherland, R., Dickens, G. R., Blum, P., Agnini, C., Alegret, L., Asatryan, G., Bhattacharya, J. P., Bordenave, A., Chang, L., Collot, J., Cramwinckel, M. J., Dallanave, E., Drake, M. K., Etienne, S. J. G., Giorgioni, M., Gurnis, M., Harper, D. T., Huang, H. H. M., Keller, A., Lam, A., Li, H., Matsui, H., Morgans, H. E. G., Newsam, C., Park, Y. H., Pekar, S. F., Penman, D. E., Saito, S., Stratford, W. R., Westerhold, T., and Zhou, X. (2019b). Expedition 371 methods. In Sutherland, R., Dickens, G.R., Blum, P., and the Expedition 371 Scientists, Tasman Frontier Subduction Initiation and Paleogene Climate. Proceedings of the International Ocean Discovery Program, 371. International Ocean Discovery Program, College Station, TX.

Sutherland, R., Dickens, G. R., Blum, P., Agnini, C., Alegret, L., Bhattacharya, J. P., Bordenave, A., Chang, L., Collot, J., Cramwinckel, M., Dallanave, E., Drake, M., Etienne, S., Giorgioni, M., Gurnis, M., Harper, D. T., Huang, H. H. M., Keller, A., Lam, A., Li, H., Matsui, H., Newsam, C., Park, Y. H., Pascher, K., Pekar, S. F., Penman, D. E., Saito, S., Stratford, W. R., Westerhold, T., and Zhou, X. (2018). Expedition 371 Preliminary Report: Tasman Frontier Subduction Initiation and Paleogene Climate. International Ocean Discovery Program.

Sutherland, R., King, P. R., and Wood, R. A. (2001). Tectonic evolution of Cretaceous rift basins in south-eastern Australia and New Zealand: implications for exploration risk assessment.

Sutherland, R., Stagpoole, V., Uruski, C. I., Kennedy, C., Bassett, D., Henrys, S., Scherwath, M., Kopp, H., Field, B., Toulmin, S., Barker, D., Bannister, S., Davey, F. J., Stern, T. A., and Flueh, E. R. (2009). Reactivation of tectonics, crustal underplating, and uplift after 60 Myr of passive subsidence, Raukumara Basin, Hikurangi-Kermadec fore arc, New Zealand: Implications for global growth and recycling of continents. Tectonics, 28(5):1-23.

Sutherland, R., Viskovic, G. P. D., Bache, F., Stagpoole, V. M., Collot, J., Rouillard, P., Hashimoto, T., Hackney, R., Higgins, K., Rollet, N., Patriat, M., and Roest, W. R. (2012). Compilation of seismic reflection data from the Tasman Frontier region, southwest Pacific. Number 1. GNS Science Report 2012/01.

Tulloch, A. J., Ramezani, J., Mortimer, N., Mortensen, J., van den Bogaard, P., and Maas, R. (2009). Cretaceous felsic volcanism in New Zealand and Lord Howe Rise (Zealandia) as a precursor to final Gondwana break-up. Geological Society, London, Special Publications, 321(1):89-118.

Turnbull, I. M. and Uruski, C. I. (1993). Cretaceous and Cenozoic sedimentary basins of western Southland, South Island, New Zealand. Institute of Geological \& Nuclear Sciences Monograph, Lower Hutt, New Zealand. 
Uruski, C. (2004). Petroleum Geology of New Zealand's Northwest Frontier: The Northland Sector of the greater Taranki Basin. PESA's Eastern Australasian Basins Symposium 2, pages 219-230.

Uruski, C. I. (2007). Seismic Interpretation Report, PEP38451 Deepwater Taranaki Basin, New Zealand: Methods, Prospects and Leads. GNS Science Consultancy Report $2007 / 105$.

Uruski, C. I., Stagpoole, V. M., Isaac, M. J., and McCormack, N. (2004). Seismic Interpretation Report - Spectrum Reprocessing Northland Basin, New Zealand. Technical report.

Vail, P. R. (1987). Seismic Stratigraphy Interpretation Using Sequence Stratigraphy Part 1: Seismic Stratigraphy Interpretation Procedure. AAPG Studies in Geology \#27, volume 1: Atlas of Seismic Stratigraphy, 1(1):1-10.

Vail, P. R., Mitchum Jr, R. M., Todd, R. G., Widmier, J. M., Thompson, S., Sangree, J. B., Bubb, J. N., and Hartleid, W. G. (1977). Seismic stratigraphy and global changes of sea-level. Seismic Stratigraphy - Applications to Hydrocarbon Exploration. American Association of Petroleum Geologists.

Van Dissen, R., Little, T. A., Nicol, A., Pettinga, J. R., and Wandres, A. M. (2005). Faults of Eastern Marlborough: Picton, Awatere and Kekerengu. In Pettinga, J. R. and Wandres, A. M., editors, In: Pettinga, J. R. and Wandres, A. M. (eds.) Field Trip Guides, Geological Society of New Zealand 50th Annual Conference, Kaikoura, New Zealand., pages 85-110. Geological Society of New Zealand Misc. Publ. 119B.

van Morkhoven, F. P. C. M., Berggren, W. A., Edwards, A. S., and Oertli, H. J. (1986). Cenozoic cosmopolitan deep-water benthic foraminifera, volume 11. Elf-Aquitaine.

Van Wagoner, J. C., Mitchum Jr, R. M., Posamentier, H. W., and Vail, P. R. (1987). Seismic straigraphy interpretation using sequence stratigraphy: Part 2: Key definitions of sequence stratigraphy. American Association of Petroleum Geologists, 27:11-14.

Walcott, R. I. (1987). Geodetic strain and the deformational history of the North Island of New Zealand during the late Cainozoic. Philosophical Transactions of the Royal Society of London. Series A, Mathematical and Physical Sciences, 321(1557):163-181.

Walcott, R. I. (1989). Paleomagnetically observed rotations along the Hikurangi Margin of New Zealand. In Paleomagnetic rotations and continental deformation, pages 459-471. Springer.

Whattam, S., Malpas, J., Ali, J., Lo, C., and Smith, I. E. M. (2005). Formation and emplacement of the Northland ophiolite, northern New Zealand: SW Pacific tectonic implications. Journal of the Geological Society, 162(2):225-241. 
Whattam, S. A., Malpas, J., Smith, I. E. M., and Ali, J. R. (2006). Link between SSZ ophiolite formation, emplacement and arc inception, Northland, New Zealand: U-Pb SHRIMP constraints; Cenozoic SW Pacific tectonic implications. Earth and Planetary Science Letters, 250(3-4):606-632.

Wood, R. A., Lamarche, G., Herzer, R. H., Delteil, J., and Davy, B. (1996). Paleogene seafloor spreading in the southeast Tasman Sea. Tectonics, 15(5):966-975.

Wright, I. C., Parson, L. M., and Gamble, J. A. (1996). Evolution and interaction of migrating cross-arc volcanism and backarc rifting : An example from the southern Havre Trough. Journal of Geophysical Research, 101(10):71-86. 
Appendix A

New Zealand geological timescale 

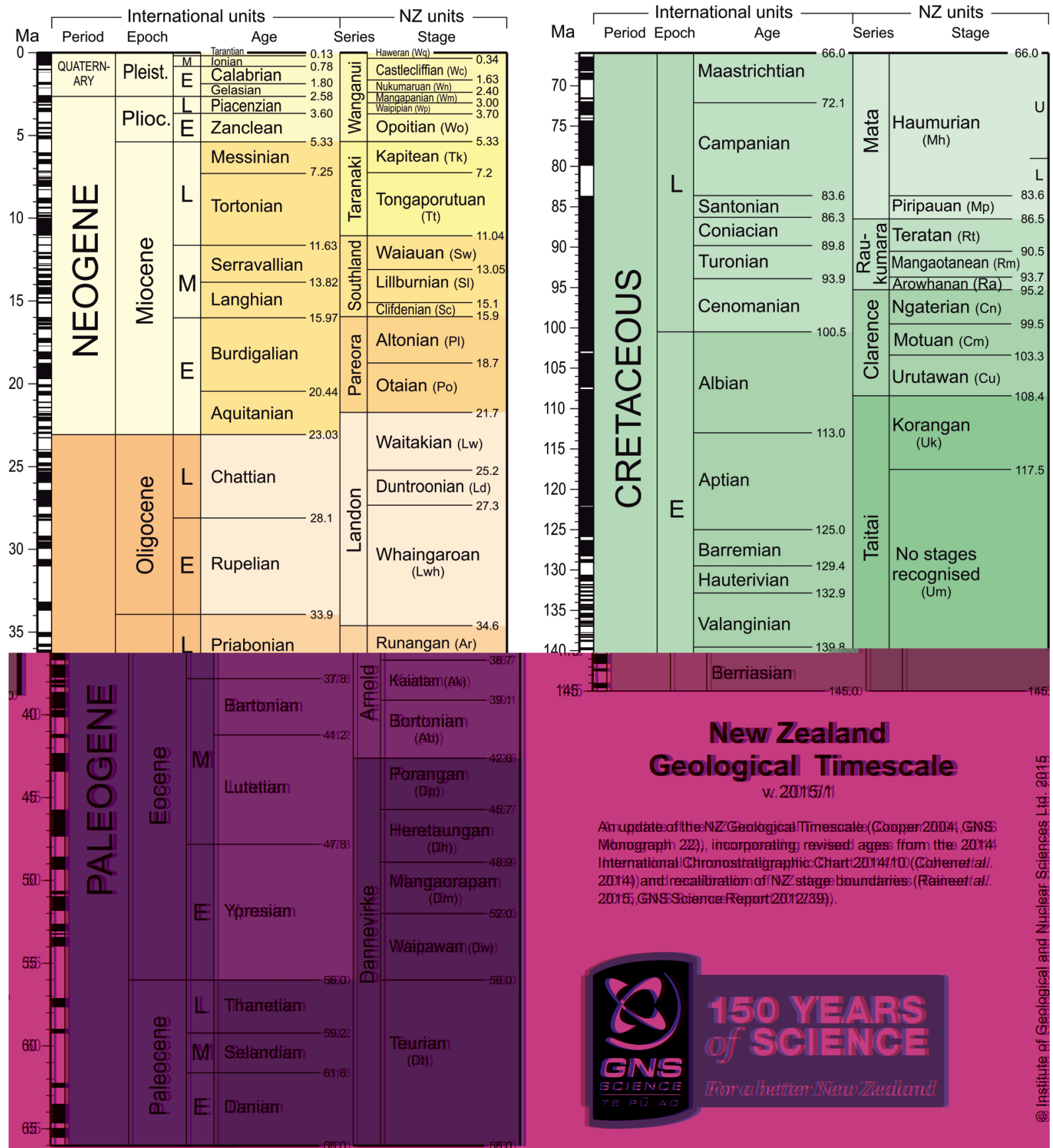

Figure A.1: New Zealand Cretaceous-Cenozoic timescale after Raine et al. (2015). 


\section{Appendix B}

\section{Seismic Data}

This appendix chapter contains information relating to the seismic interpretation chapter of this thesis. Included are information about seismic acquisition parameters of 2D seismic surveys used in this study (Table B.1), and the data points used for time-to-depth conversion (Table B.2). Included Taranaki wells for the time-to-depth conversion are: Ariki-1 (Shell BP and Todd Oil Services Ltd., 1984), Kahawai-1 (NZ Oil and Gas Ltd, 1990), Kiwi-1 (New Zealand Overseas Petroleum Ltd, 2004), Kora-4 (ARCO Petroleum NZ Inc., 1988), Mangaa-1 (Hematite Petroleum NZ Ltd, 1970), Pukeko-1 (New Zealand Overseas Petroleum Ltd, 2010), Taimana-1 (Diamond Shamrock Exploration Oil Co NZ, 1984), Tane-1 (Shell BP and Todd Oil Services Ltd., 1976), Tangaroa-1 (Shell BP and Todd Oil Services Ltd., 1981), Taranga-1 (Shell BP and Todd Oil Services Ltd., 1992) and Tua Tua-1 (Rankin and Gray, 1988). Data were provided by Wanda Stratford (GNS).

\section{B.1 Seismic survey details}

Table B.1: Acquisition parameters of seismic data used in this study.

\begin{tabular}{cccccc} 
Survey & $\begin{array}{c}\text { Length } \\
(\mathbf{k m})\end{array}$ & $\begin{array}{c}\text { Air Gun Vol. } \\
(\mathbf{c u} / \mathbf{i n})\end{array}$ & $\begin{array}{c}\text { Shot Interval } \\
(\mathbf{m})\end{array}$ & $\begin{array}{c}\text { Streamer } \\
\text { Length }(\mathbf{m})\end{array}$ & PR \\
\hline & & & & & \\
114 & 3191 & 3000 & 50 & 3000 & N/A \\
CNL95 & 7000 & 2660 & 30.48 & 6020 & 2207 \\
CNL98 & 7000 & 2660 & 30.48 & 6020 & 2174 \\
DTB-01 & 6700 & 3500 & 25 & 6000 & 4382 \\
GS82 & 1606 & 2520 & 25 & 2400 & 959 \\
REI09 & 5000 & 5000 & 25 & 7500 & 3980 \\
STRAT09 & 1441 & 5000 & 37.5 & 7500 & 4382
\end{tabular}




\section{B.2 Time-to-depth points}

Table B.2: Calculated two-way-time with depth values from check shot data in boreholes.

Borehole Depth (m bsf) Time Model depth Residual

\begin{tabular}{|c|c|c|c|c|}
\hline & & (s bsf) & $(\mathrm{m})$ & \\
\hline U1508 & 0.00 & 0.00 & 0.00 & 0.00 \\
\hline U1508 & 92.85 & 0.11 & 100.47 & -7.62 \\
\hline U1508 & 208.79 & 0.24 & 220.32 & -11.53 \\
\hline U1508 & 337.05 & 0.37 & 347.39 & -10.34 \\
\hline U1508 & 378.17 & 0.41 & 387.13 & -8.95 \\
\hline U1508 & 485.91 & 0.51 & 489.29 & -3.37 \\
\hline U1508 & 739.78 & 0.73 & 720.94 & 18.83 \\
\hline Waka Nui-1 & 692.00 & 0.75 & 742.29 & -50.29 \\
\hline Waka Nui-1 & 735.00 & 0.78 & 785.35 & -50.35 \\
\hline Waka Nui-1 & 948.00 & 0.97 & 1004.61 & -56.61 \\
\hline Waka Nui-1 & 1100.00 & 1.08 & 1140.54 & -40.54 \\
\hline Waka Nui-1 & 1131.00 & 1.10 & 1164.24 & -33.24 \\
\hline Waka Nui-1 & 1285.00 & 1.20 & 1284.62 & 0.38 \\
\hline Waka Nui-1 & 1361.00 & 1.27 & 1376.66 & -15.66 \\
\hline Waka Nui-1 & 1441.00 & 1.34 & 1471.79 & -30.79 \\
\hline Waka Nui-1 & 1472.00 & 1.36 & 1502.56 & -30.56 \\
\hline Waka Nui-1 & 1541.00 & 1.42 & 1580.97 & -39.97 \\
\hline Waka Nui-1 & 1639.00 & 1.50 & 1688.28 & -49.28 \\
\hline Waka Nui-1 & 1985.00 & 1.76 & 2065.78 & -80.78 \\
\hline Waka Nui-1 & 2036.00 & 1.80 & 2119.33 & -83.33 \\
\hline Waka Nui-1 & 2097.00 & 1.84 & 2177.86 & -80.86 \\
\hline Waka Nui-1 & 2202.00 & 1.89 & 2253.67 & -51.67 \\
\hline Ariki-1 & 302.50 & 0.09 & 83.54 & 218.96 \\
\hline Ariki-1 & 2227.30 & 1.93 & 2328.58 & -101.28 \\
\hline Ariki-1 & 3202.60 & 2.50 & 3254.59 & -51.99 \\
\hline Ariki-1 & 4639.80 & 3.32 & 4810.53 & -170.73 \\
\hline Kahawai-1 & 581.00 & 0.62 & 606.83 & -25.83 \\
\hline Kahawai-1 & 761.00 & 0.80 & 800.69 & -39.69 \\
\hline Kahawai-1 & 966.00 & 0.98 & 1019.62 & -53.62 \\
\hline Kahawai-1 & 1281.00 & 1.24 & 1343.31 & -62.31 \\
\hline Kahawai-1 & 1456.00 & 1.38 & 1523.31 & -67.31 \\
\hline Kahawai-1 & 1606.00 & 1.49 & 1681.94 & -75.94 \\
\hline
\end{tabular}




\begin{tabular}{|c|c|c|c|c|}
\hline Kahawai-1 & 1801.00 & 1.64 & 1885.40 & -84.40 \\
\hline Kahawai-1 & 2001.00 & 1.76 & 2072.35 & -71.35 \\
\hline Kahawai-1 & 2206.00 & 1.88 & 2240.62 & -34.62 \\
\hline Kahawai-1 & 2401.00 & 1.98 & 2397.68 & 3.32 \\
\hline Kahawai-1 & 2606.00 & 2.09 & 2577.53 & 28.47 \\
\hline Kahawai-1 & 2806.00 & 2.20 & 2748.83 & 57.17 \\
\hline Kahawai-1 & 3006.00 & 2.31 & 2930.74 & 75.26 \\
\hline Kahawai-1 & 3206.00 & 2.42 & 3123.74 & 82.26 \\
\hline Kiwi-1 & 0.00 & 0.00 & -6.21 & 6.21 \\
\hline Kiwi-1 & 538.00 & 0.57 & 550.22 & -12.22 \\
\hline Kiwi-1 & 771.00 & 0.79 & 793.34 & -22.34 \\
\hline Kiwi-1 & 916.00 & 0.88 & 897.70 & 18.30 \\
\hline Kiwi-1 & 1185.00 & 1.10 & 1159.57 & 25.43 \\
\hline Kiwi-1 & 1576.00 & 1.42 & 1585.56 & -9.56 \\
\hline Kiwi-1 & 2266.00 & 1.86 & 2213.33 & 52.67 \\
\hline Kiwi-1 & 2741.00 & 2.13 & 2645.05 & 95.95 \\
\hline Kiwi-1 & 2801.00 & 2.16 & 2693.60 & 107.40 \\
\hline Kiwi-1 & 2871.00 & 2.20 & 2758.79 & 112.21 \\
\hline Kiwi-1 & 2986.00 & 2.27 & 2867.58 & 118.42 \\
\hline Kiwi-1 & 3036.00 & 2.30 & 2917.53 & 118.47 \\
\hline Kiwi-1 & 3146.00 & 2.36 & 3015.02 & 130.98 \\
\hline Kiwi-1 & 3246.00 & 2.41 & 3103.40 & 142.60 \\
\hline Kiwi-1 & 3350.00 & 2.46 & 3185.82 & 164.18 \\
\hline Kiwi-1 & 3449.00 & 2.51 & 3279.54 & 169.46 \\
\hline Kiwi-1 & 3566.00 & 2.58 & 3391.89 & 174.11 \\
\hline Kiwi-1 & 3663.00 & 2.61 & 3459.28 & 203.72 \\
\hline Kora-4 & 1337.00 & 1.30 & 1425.01 & -88.01 \\
\hline Kora-4 & 2737.00 & 2.20 & 2759.19 & -22.19 \\
\hline Kora-4 & 2787.00 & 2.23 & 2801.21 & -14.21 \\
\hline Kora-4 & 2842.00 & 2.26 & 2851.07 & -9.07 \\
\hline Kora-4 & 2959.00 & 2.32 & 2944.70 & 14.30 \\
\hline Kora-4 & 3012.00 & 2.35 & 2992.44 & 19.56 \\
\hline Kora-4 & 3062.00 & 2.38 & 3044.19 & 17.81 \\
\hline Kora-4 & 3087.00 & 2.39 & 3067.97 & 19.03 \\
\hline Kora-4 & 3159.50 & 2.43 & 3141.11 & 18.39 \\
\hline Kora-4 & 3213.00 & 2.47 & 3200.37 & 12.63 \\
\hline Kora-4 & 3262.00 & 2.50 & 3254.11 & 7.89 \\
\hline Kora-4 & 3306.00 & 2.53 & 3307.50 & -1.50 \\
\hline Mangaa-1 & 484.60 & 0.54 & 517.66 & -33.06 \\
\hline
\end{tabular}




\begin{tabular}{|c|c|c|c|c|}
\hline Mangaa-1 & 850.30 & 0.90 & 922.31 & -72.01 \\
\hline Mangaa-1 & 1216.10 & 1.22 & 1312.99 & -96.89 \\
\hline Mangaa-1 & 1597.10 & 1.51 & 1707.80 & -110.70 \\
\hline Mangaa-1 & 1734.20 & 1.61 & 1840.41 & -106.21 \\
\hline Mangaa-1 & 1947.60 & 1.76 & 2067.30 & -119.70 \\
\hline Mangaa-1 & 2069.50 & 1.84 & 2186.95 & -117.45 \\
\hline Mangaa-1 & 2282.90 & 1.98 & 2395.49 & -112.59 \\
\hline Mangaa-1 & 2374.30 & 2.03 & 2483.24 & -108.94 \\
\hline Mangaa-1 & 2465.80 & 2.09 & 2568.90 & -103.10 \\
\hline Mangaa-1 & 2679.10 & 2.22 & 2776.00 & -96.90 \\
\hline Mangaa-1 & 2770.60 & 2.26 & 2845.20 & -74.60 \\
\hline Mangaa-1 & 2862.00 & 2.31 & 2925.05 & -63.05 \\
\hline Mangaa-1 & 3014.40 & 2.38 & 3049.72 & -35.32 \\
\hline Mangaa-1 & 3136.30 & 2.45 & 3162.53 & -26.23 \\
\hline Mangaa-1 & 3212.50 & 2.48 & 3221.23 & -8.73 \\
\hline Mangaa-1 & 3288.70 & 2.52 & 3283.84 & 4.86 \\
\hline Mangaa-1 & 3380.20 & 2.56 & 3364.49 & 15.71 \\
\hline Pukeko-1 & 143.00 & 0.16 & 142.77 & 0.23 \\
\hline Pukeko-1 & 342.60 & 0.38 & 352.79 & -10.19 \\
\hline Pukeko-1 & 543.00 & 0.58 & 558.61 & -15.61 \\
\hline Pukeko-1 & 742.80 & 0.76 & 762.71 & -19.91 \\
\hline Pukeko-1 & 943.00 & 0.93 & 957.30 & -14.30 \\
\hline Pukeko-1 & 1143.00 & 1.09 & 1147.78 & -4.78 \\
\hline Pukeko-1 & 1243.00 & 1.16 & 1245.46 & -2.46 \\
\hline Pukeko-1 & 1367.90 & 1.26 & 1366.74 & 1.16 \\
\hline Pukeko-1 & 1468.00 & 1.33 & 1460.45 & 7.55 \\
\hline Pukeko-1 & 1542.90 & 1.38 & 1531.60 & 11.30 \\
\hline Pukeko-1 & 1730.00 & 1.51 & 1710.53 & 19.47 \\
\hline Pukeko-1 & 1942.80 & 1.65 & 1906.99 & 35.81 \\
\hline Pukeko-1 & 2042.90 & 1.71 & 1996.81 & 46.09 \\
\hline Pukeko-1 & 2136.00 & 1.77 & 2078.98 & 57.02 \\
\hline Pukeko-1 & 2244.90 & 1.83 & 2176.57 & 68.33 \\
\hline Pukeko-1 & 2356.90 & 1.90 & 2272.28 & 84.62 \\
\hline Pukeko-1 & 2543.00 & 2.00 & 2433.10 & 109.90 \\
\hline Pukeko-1 & 2743.00 & 2.11 & 2605.62 & 137.38 \\
\hline Pukeko-1 & 2772.90 & 2.13 & 2631.63 & 141.27 \\
\hline Pukeko-1 & 2858.00 & 2.17 & 2703.49 & 154.51 \\
\hline Pukeko-1 & 2942.90 & 2.21 & 2775.06 & 167.84 \\
\hline Pukeko-1 & 3005.10 & 2.25 & 2829.50 & 175.60 \\
\hline
\end{tabular}




\begin{tabular}{|c|c|c|c|c|}
\hline Pukeko-1 & 3193.00 & 2.32 & 2946.47 & 246.53 \\
\hline Pukeko-1 & 3193.00 & 2.34 & 2989.26 & 203.74 \\
\hline Pukeko-1 & 3343.00 & 2.42 & 3113.46 & 229.54 \\
\hline Pukeko-1 & 3508.00 & 2.50 & 3254.45 & 253.55 \\
\hline Pukeko-1 & 3543.00 & 2.52 & 3285.08 & 257.92 \\
\hline Pukeko-1 & 3742.90 & 2.60 & 3439.42 & 303.48 \\
\hline Pukeko-1 & 3843.00 & 2.65 & 3515.68 & 327.32 \\
\hline Pukeko-1 & 3942.90 & 2.69 & 3594.86 & 348.04 \\
\hline Pukeko-1 & 4036.00 & 2.73 & 3669.86 & 366.14 \\
\hline Pukeko-1 & 4070.00 & 2.75 & 3697.39 & 372.61 \\
\hline Taimana-1 & 920.00 & 0.92 & 945.98 & -25.98 \\
\hline Taimana-1 & 1320.00 & 1.25 & 1349.78 & -29.78 \\
\hline Taimana-1 & 1830.00 & 1.60 & 1826.98 & 3.02 \\
\hline Taimana-1 & 2325.00 & 1.90 & 2275.07 & 49.93 \\
\hline Taimana-1 & 2757.00 & 2.13 & 2643.92 & 113.08 \\
\hline Taimana-1 & 3023.00 & 2.27 & 2873.35 & 149.65 \\
\hline Taimana-1 & 3050.00 & 2.29 & 2896.64 & 153.36 \\
\hline Taimana-1 & 3080.00 & 2.30 & 2922.67 & 157.33 \\
\hline Taimana-1 & 3219.00 & 2.39 & 3075.19 & 143.81 \\
\hline Taimana-1 & 3430.00 & 2.53 & 3312.82 & 117.18 \\
\hline Taimana-1 & 3570.00 & 2.63 & 3477.89 & 92.11 \\
\hline Taimana-1 & 3852.00 & 2.79 & 3785.79 & 66.21 \\
\hline Taimana-1 & 4028.00 & 3.09 & 4347.01 & -319.01 \\
\hline Tane-1 & 501.30 & 0.42 & 394.51 & 106.79 \\
\hline Tane-1 & 806.10 & 0.72 & 710.76 & 95.34 \\
\hline Tane-1 & 851.80 & 1.01 & 1055.40 & -203.60 \\
\hline Tane-1 & 1293.80 & 1.25 & 1358.23 & -64.43 \\
\hline Tane-1 & 1545.20 & 1.49 & 1681.19 & -135.99 \\
\hline Tane-1 & 1918.60 & 1.69 & 1965.70 & -47.10 \\
\hline Tane-1 & 1949.10 & 1.72 & 2009.58 & -60.48 \\
\hline Tane-1 & 2192.90 & 1.87 & 2233.71 & -40.81 \\
\hline Tane-1 & 2360.60 & 1.97 & 2379.73 & -19.13 \\
\hline Tane-1 & 2467.20 & 2.01 & 2450.00 & 17.20 \\
\hline Tane-1 & 2497.70 & 2.05 & 2513.05 & -15.35 \\
\hline Tane-1 & 2817.80 & 2.29 & 2903.12 & -85.32 \\
\hline Tane-1 & 3015.90 & 2.43 & 3139.96 & -124.06 \\
\hline Tane-1 & 3137.80 & 2.50 & 3260.94 & -123.14 \\
\hline Tane-1 & 3290.20 & 2.58 & 3401.31 & -111.11 \\
\hline Tane-1 & 3335.90 & 2.63 & 3490.18 & -154.28 \\
\hline
\end{tabular}




\begin{tabular}{|c|c|c|c|c|}
\hline Tane-1 & 3442.60 & 2.69 & 3597.97 & -155.37 \\
\hline Tane-1 & 3488.30 & 2.72 & 3643.25 & -154.95 \\
\hline Tane-1 & 3549.30 & 2.73 & 3670.53 & -121.23 \\
\hline Tane-1 & 3732.20 & 2.84 & 3863.66 & -131.46 \\
\hline Tane-1 & 3808.40 & 2.89 & 3966.37 & -157.97 \\
\hline Tane-1 & 3915.00 & 2.94 & 4051.18 & -136.18 \\
\hline Tane-1 & 4006.50 & 3.01 & 4194.11 & -187.61 \\
\hline Tane-1 & 4235.10 & 3.11 & 4387.75 & -152.65 \\
\hline Tane-1 & 4296.00 & 3.13 & 4426.90 & -130.90 \\
\hline Tangaroa-1 & 165.00 & 0.07 & 59.32 & 105.68 \\
\hline Tangaroa-1 & 347.00 & 0.33 & 306.79 & 40.21 \\
\hline Tangaroa-1 & 961.00 & 0.92 & 950.44 & 10.56 \\
\hline Tangaroa-1 & 1361.00 & 1.24 & 1338.80 & 22.20 \\
\hline Tangaroa-1 & 1561.00 & 1.47 & 1654.98 & -93.98 \\
\hline Tangaroa-1 & 2561.00 & 2.12 & 2623.57 & -62.57 \\
\hline Tangaroa-1 & 3161.00 & 2.45 & 3176.54 & -15.54 \\
\hline Tangaroa-1 & 3261.00 & 2.51 & 3280.58 & -19.58 \\
\hline Tangaroa-1 & 3372.00 & 2.57 & 3371.77 & 0.23 \\
\hline Tangaroa-1 & 3461.00 & 2.62 & 3460.35 & 0.65 \\
\hline Tangaroa-1 & 3561.00 & 2.67 & 3564.19 & -3.19 \\
\hline Tangaroa-1 & 3761.00 & 2.79 & 3775.39 & -14.39 \\
\hline Tangaroa-1 & 3830.00 & 2.83 & 3841.90 & -11.90 \\
\hline Taranga-1 & 440.00 & 0.18 & 159.31 & 280.69 \\
\hline Taranga-1 & 768.00 & 0.77 & 774.61 & -6.61 \\
\hline Taranga-1 & 910.00 & 0.89 & 913.51 & -3.51 \\
\hline Taranga-1 & 1140.00 & 1.09 & 1153.70 & -13.70 \\
\hline Taranga-1 & 1350.00 & 1.28 & 1399.70 & -49.70 \\
\hline Taranga-1 & 1575.00 & 1.43 & 1600.85 & -25.85 \\
\hline Taranga-1 & 1654.00 & 1.51 & 1700.20 & -46.20 \\
\hline Taranga-1 & 1840.00 & 1.63 & 1875.54 & -35.54 \\
\hline Taranga-1 & 2040.00 & 1.76 & 2065.14 & -25.14 \\
\hline Taranga-1 & 2240.00 & 1.88 & 2248.44 & -8.44 \\
\hline Taranga-1 & 2440.00 & 2.00 & 2430.68 & 9.32 \\
\hline Taranga-1 & 2629.00 & 2.10 & 2582.54 & 46.46 \\
\hline Taranga-1 & 2730.00 & 2.16 & 2682.32 & 47.68 \\
\hline Taranga-1 & 2736.00 & 2.14 & 2659.67 & 76.33 \\
\hline Taranga-1 & 3065.00 & 2.39 & 3074.44 & -9.44 \\
\hline Taranga-1 & 3282.00 & 2.55 & 3337.30 & -55.30 \\
\hline Taranga-1 & 3555.00 & 2.72 & 3644.48 & -89.48 \\
\hline
\end{tabular}




\begin{tabular}{|c|c|c|c|c|}
\hline Taranga-1 & 3811.00 & 2.85 & 3890.96 & -79.96 \\
\hline Taranga-1 & 3946.00 & 2.93 & 4033.55 & -87.55 \\
\hline Taranga-1 & 4026.00 & 2.97 & 4120.83 & -94.83 \\
\hline Tua Tua-1 & 391.00 & 0.45 & 422.10 & -31.10 \\
\hline Tua Tua-1 & 731.00 & 0.79 & 797.14 & -66.14 \\
\hline Tua Tua-1 & 996.00 & 1.04 & 1093.11 & -97.11 \\
\hline Tua Tua-1 & 1331.00 & 1.32 & 1447.02 & -116.02 \\
\hline Tua Tua-1 & 1406.00 & 1.37 & 1516.78 & -110.78 \\
\hline Tua Tua-1 & 1606.00 & 1.50 & 1688.99 & -82.99 \\
\hline Tua Tua-1 & 1811.00 & 1.61 & 1845.18 & -34.18 \\
\hline Tua Tua-1 & 1991.00 & 1.69 & 1963.54 & 27.46 \\
\hline Tua Tua-1 & 2188.00 & 1.78 & 2096.11 & 91.89 \\
\hline Tua Tua-1 & 2411.00 & 1.87 & 2238.33 & 172.67 \\
\hline Tua Tua-1 & 2591.00 & 1.94 & 2330.68 & 260.32 \\
\hline Tua Tua-1 & 2691.00 & 1.96 & 2372.02 & 318.98 \\
\hline Wainui-1 & 145.40 & 0.13 & 118.19 & 27.21 \\
\hline Wainui-1 & 402.40 & 0.45 & 424.95 & -22.55 \\
\hline Wainui-1 & 595.29 & 0.65 & 639.24 & -43.94 \\
\hline Wainui-1 & 895.29 & 0.92 & 942.99 & -47.70 \\
\hline Wainui-1 & 1045.29 & 1.05 & 1100.28 & -54.99 \\
\hline Wainui-1 & 1395.29 & 1.33 & 1459.38 & -64.10 \\
\hline Wainui-1 & 1505.14 & 1.41 & 1572.52 & -67.38 \\
\hline Wainui-1 & 1870.53 & 1.67 & 1939.67 & -69.13 \\
\hline Wainui-1 & 2018.44 & 1.76 & 2071.25 & -52.81 \\
\hline Wainui-1 & 2048.35 & 1.79 & 2103.80 & -55.45 \\
\hline Wainui-1 & 2118.14 & 1.82 & 2157.68 & -39.54 \\
\hline Wainui-1 & 2138.12 & 1.84 & 2181.77 & -43.64 \\
\hline Wainui-1 & 2218.08 & 1.89 & 2254.58 & -36.49 \\
\hline Wainui-1 & 2368.05 & 1.97 & 2387.04 & -18.99 \\
\hline Wainui-1 & 2767.90 & 2.20 & 2757.43 & 10.47 \\
\hline Wainui-1 & 2837.90 & 2.25 & 2829.93 & 7.97 \\
\hline Wainui-1 & 2857.90 & 2.26 & 2849.78 & 8.12 \\
\hline Wainui-1 & 2957.90 & 2.33 & 2966.56 & -8.66 \\
\hline Wainui-1 & 3017.89 & 2.38 & 3054.41 & -36.52 \\
\hline Wainui-1 & 3057.88 & 2.42 & 3112.54 & -54.66 \\
\hline Wainui-1 & 3157.72 & 2.49 & 3243.73 & -86.01 \\
\hline Wainui-1 & 3257.15 & 2.57 & 3380.47 & -123.31 \\
\hline Wainui-1 & 3366.60 & 2.65 & 3526.51 & -159.91 \\
\hline Wainui-1 & 3433.31 & 2.70 & 3609.54 & -176.23 \\
\hline
\end{tabular}


Wainui-1

3466.18

2.71

3638.72

$-172.54$

Wainui-1

3521.02

2.75

3696.97

$-175.95$

Wainui-1

3656.01

2.81

3823.06

$-167.05$

Wainui-1

3686.01

2.83

3860.13

$-174.12$ 


\section{B.3 Location of seismic figures}

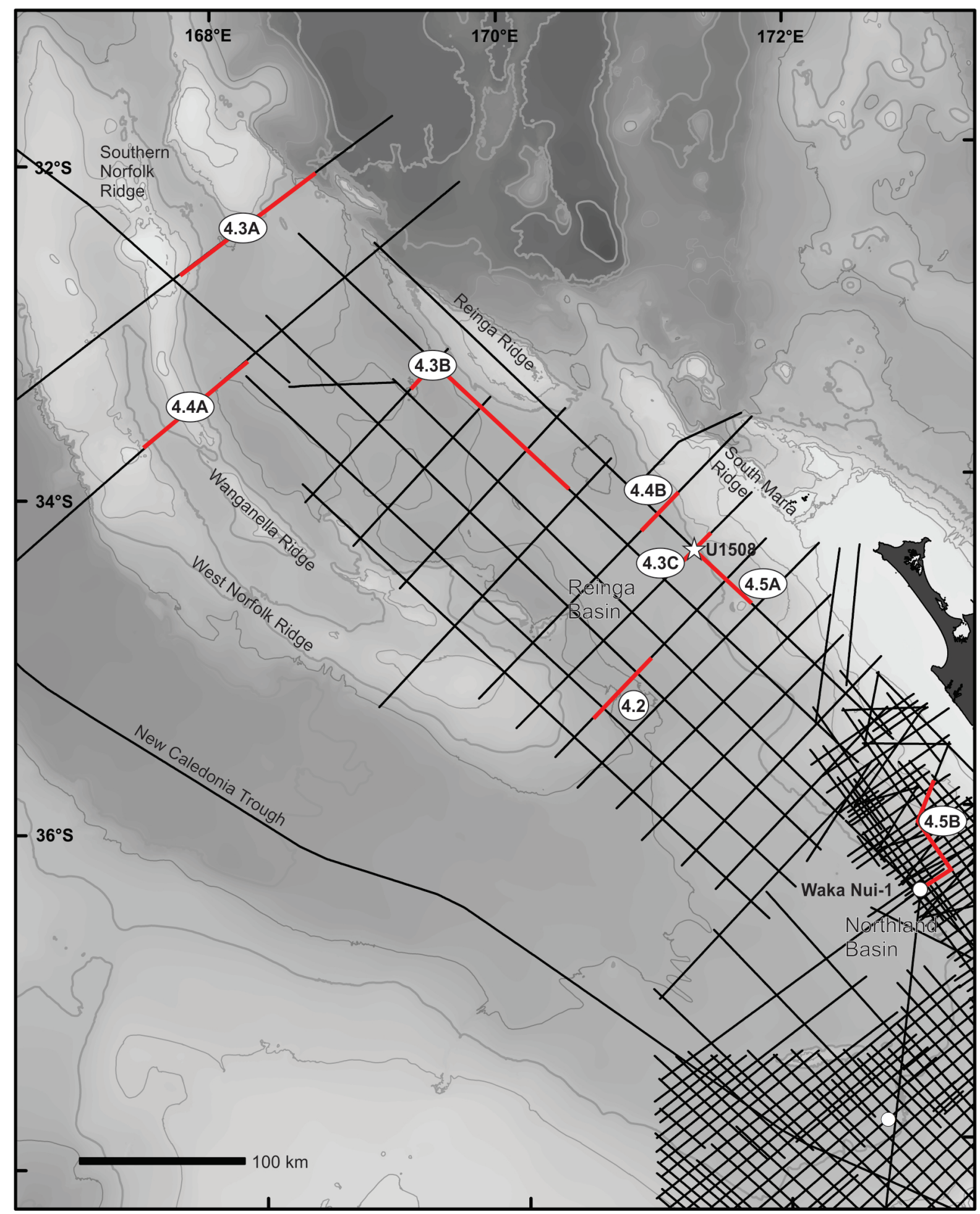

Figure B.1: Location map of seismic data used in this thesis. Red lines indicate the approximate location of seismic sections and numbers refer to the figure number in Chapter 4. 
